\title{
A Balaton vízszintváltozásának tendenciái a régészeti korszakokban
}

\author{
PhD értekezés
}

\section{Serlegi Gábor}

külső témavezető:

Dr. Bondár Mária Csc (PhD) tudományos fömunkatárs

MTA BTK

Régészeti Intézet belső konzulens:

Prof. Dr. Sümegi Pál

tanszékvezető egyetemi tanár SZTE TTIK

Földtani és Őslénytani Tanszék

SZTE TTIK Földtudományok Doktori Iskola

Földtani és Öslénytani Tanszék 



\section{Tartalomjegyzék}

1. Bevezetés 5

1.1 A disszertáció célja - a kutatás témájának felvázolása 5

$\begin{array}{ll}1.2 \text { A disszertáció főbb szerkezeti egységei } & 8\end{array}$

2. A környezetrégészet elméleti fejlődése 10

2.1 A régészet és a környezetrégészet viszonya 10

2.2 A környezetrégészeti gondolkodás fejlődése 13

3. A kutatásba bevont terület ismertetése 24

3.1 A tágabb nagytáji földrajzi környezet 24

3.2 Részletesen vizsgált kistájak jellemzői 25

3.2.1 Somogyi parti sík $\quad 26$

$\begin{array}{ll}3.2 .2 \text { Nagyberek } & 28\end{array}$

3.2.3. Kis-Balatoni-medence $\quad 30$

$\begin{array}{ll}\text { 3.2.4. Marcali-hát } & 32\end{array}$

$\begin{array}{ll}\text { 3.3 A Balaton } & 34\end{array}$

3.3.1 A Balaton geológiája

3.3.2 A Balaton vízrajza és üledékviszonyai 36

3.3.3 A Balaton vízháztartása $\quad 37$

3.3.4 A Balaton hatása az emberi megtelepedésre 38

4. A Balaton vízállásváltozásának régészeti kutatása 42

4.1 Az 1960-70-es évek kutatásai 42

$\begin{array}{ll}\text { 4.2 Az utóbbi évtized kutatásai } & 47\end{array}$ 
5.2 A lelőhely területének rétegtani vizsgálatai

5.2.1 A vizsgálathoz felhasznált adatok $\quad 58$

5.2.2 A szerkesztés során alkalmazott módszer 61

$\begin{array}{ll}\text { 5.2.3 Eredmények és következtetések } & 61\end{array}$

5.3 A régészeti korszakok megtelepedési zónái a lelőhelyen 66

5.3.1 A középső rézkor - Balaton-Lasinja kultúra időszaka 66

5.3.2 A késő rézkor - Boleráz-Badeni kultúra időszaka 67

5.3.3 A kora és középső bronzkor -Somogyvár-Vinkovci, Kisapostagi és Mészbetétes Kerámia kultúrák időszaka $\quad 70$

5.3.4 A késő vaskor - La Téne C-D kultúra időszaka 72

5.3.5 A népvándorlás kor (Langobard) időszaka 73

5.3.6 Az Árpád-kor időszaka $\quad 75$

5.3.7 A középkor időszaka $\quad 75$

5.4 A talajvízmodell és a korszakonkénti megtelepedési zónák közötti összefüggések összefoglalása $\quad 77$

5.5 A balatonkeresztúri lelőhely régészeti korszakainak abszolút kronológiája

6. A balatonkeresztúri lelőhely és a Nagyberek környezettörténeti rekonstrukciójának problematikája

6.1 A mintavételezés helyszíne

6.2 A fúrásminta palinológiai értékelésének módszere 85

6.3 A vizsgálati eredmények rövid összefoglalása 85 
$\begin{array}{ll}7.1 \text { A kiválasztott terület } & 88\end{array}$

7.2 A modell létrehozása során használt módszerek 89

$\begin{array}{ll}\text { 7.2.1 A vízborítás modellezése } & 90\end{array}$

$\begin{array}{ll}\text { 7.2.2 A felszíni vízfolyások modellezése } & 91\end{array}$

$\begin{array}{ll}\text { 7.2.3 A domborzati sajátosságok modellezése } & 91\end{array}$

7.2.4 Az üledékviszonyok, a talajtakaró és a felszíni alatti $\begin{array}{ll}\text { hidrológia modellezése } & 92\end{array}$

7.2.5 A régészeti lelőhelyek állományának integrálása 94

7.3 A modellből levonható általános következtetések 95

$\begin{array}{ll}\text { 7.3.1 Üledékek, talajok } & 96\end{array}$

$\begin{array}{lll}\text { 7.3.2 Domborzati sajátosságok } & 96\end{array}$

$\begin{array}{ll}\text { 7.3.3 Felszíni és felszín alatti hidrológia } & 98\end{array}$

$\begin{array}{ll}\text { 7.4 A Kis-Balaton szigetei } & 103\end{array}$

8. A statikus vízkitöltési modell és a régészeti lelőhelyek geomorfológiai helyzete közötti összefüggések elemzése

$\begin{array}{lr}\text { 8.1 A lelőhelyek } & 106\end{array}$

$\begin{array}{ll}\text { 8.2 A neolitikum időszaka } & 107\end{array}$

8.2.1 A Vonaldíszes Kerámia kultúrájának időszaka 107

$\begin{array}{ll}\text { 8.2.2 A Lengyeli kultúra időszaka } & 108\end{array}$

8.2.3 A több korszakú neolitikus lelőhelyek 109

$\begin{array}{ll}\text { 8.3 A középső rézkor időszaka } & 111\end{array}$

8.4 A késő rézkor időszaka $\quad 112$

$\begin{array}{ll}\text { 8.5 A kora bronzkor időszaka } & 114\end{array}$ 
8.5.1 A Somogyvár-Vinkovci kultúra időszaka

8.5.2 A Kisapostagi kultúra időszaka 116

8.5.3 A kora bronzkori időszak több korszakú lelőhelyei 117

8.6 A középső bronzkor időszaka 117

8.7 A kora és középső bronzkori több korszakú lelőhelyek 118

8.8 A késő bronzkor időszaka 119

8.9 A késő vaskor időszaka $\quad 121$

8.10 A kora rómaikor időszaka 122

8.11 A több korszakú lelőhelyekből levonható következtetések 126

$\begin{array}{ll}\text { 8.12 Összegzés } & 128\end{array}$

8.13 A környezeti és kulturális tényezők kapcsolata 130

9. Összefoglalás 162

$\begin{array}{lr}\text { 10. Conclusion } & 167\end{array}$

Köszönetnyilvánítás 169

$\begin{array}{lr}\text { Irodalomjegyzék } & \mathbf{1 7 0}\end{array}$

\section{Mellékletek}

1. számú melléklet:

A Balatonkeresztúr-Réti-dűlőn végzett talajmechanikai fúrások kiértékelő adatlapjainak másolatai

2. számú melléklet:

A Balatonkeresztúr-Réti dűlő közelében vett környezettörténeti mintasor pollenelemzésének eredményei

3. számú melléklet:

A vizsgált terület régészeti lelőhelyeinek korszakonkénti összefoglaló táblázata 


\section{Bevezetés}

\subsection{A disszertáció célja - a kutatás témájának felvázolása}

A Balaton, mint hazánk legnagyobb kiterjedésű állóvize napjainkban is fontos és kiemelt szerepet tölt be az ország modern kori történetében gazdaságilag, főleg turisztikailag hasznosítható értelemben. Ezen túl azonban a magyar lakosság nagy részének már gyermekkorától jelentős emlékanyaga származik a tó közelében töltött időszakokból így a Balatont nem csupán egy jól körülírható földrajzi egységként, hanem az emberek tudatában leképezve egyfajta kulturális-elemként is felfoghatjuk

A tó jelenlegi állapotának és folyamatos használhatóságának fenntartását napjainkra komoly törvényi szabályozás, vízgazdálkodási terv és intézkedési rendszer biztosítja, hogy a partjai mentén élők és az évről évre visszatérő vendégek személyi és anyagi biztonságát, kényelmét és az ehhez szükséges modern infrastruktúrát hosszútávon fent lehessen tartani (2000. évi CXII. törvény és ennek módosítása a 2013. évi XLVII. törvény).

Ezek az intézkedéssorozatok egy olyan, mára már gyakorlatilag visszafordíthatatlan folyamatok által kialakított környezeti állapot egyensúlyának fenntartására és biztosítására, valamint szabályozott fejlesztésére irányulnak, amely a közel kétezer évvel ezelőtt kezdődő és az elmúlt, megközelítőleg 200-250 évben rohamosan gyorsuló antropogén beavatkozásoknak az eredménye (Virág 1997, 391-460.).

Ennek az állapotnak a fenntartása egy folyamatos interakciót követel meg ember és természet között. Közel sem jelenthető ki, hogy a beavatkozások következtében optimális, egyensúlyi állapot jött létre. Minden egyes jelentősebb természeti változás emberi beavatkozást von maga után, amelyek várt, vagy nem várt természeti folyamatokat generálhatnak.

Ez a folyamat nem az antropogén hatások eredménye, nem az elmúlt évszázadok során kezdődött. Az emberi beavatkozás eredményeként a reakciók amplitúdója megnövekedett, a természetes egyensúlyi állapottól eltérő állapot fenntartása egyre jelentősebb intézkedési rendszer meglétét igényli. A tó környezetében élő emberi társadalmak azonban mindig is szoros kötelékben éltek a tóval és annak 
közvetlen és tágabb környezetével. A dolgozat célja, hogy az utóbbi évtized során felhalmozódott, elsősorban régészeti adatmennyiség alapján kiegészítse és esetlegesen új keretek közé helyezze azt a már nem előzmények nélküli kutatást, amely a tó és az emberek közötti viszonyt és elsősorban a tó vízállásában bekövetkezett változások valamint az egykori települések elhelyezkedése közötti összefüggést vizsgálta (Bendefy 1968; Bendefy 1970; Bendefy 1972; Bendefy-V. Nagy 1969; Sági 1968a; Sági 1968b; Sági 1970; Sági 1971; Sági-Füzesi 1973.).

A vizsgálatokat a terjedelmi és tematikai keret megtartása érdekében egy meghatározott lelőhely köré csoportosítottam. Az M7 autópálya építését megelőző régészeti munkálatok során a Marcali-löszhát és a Nagyberek határán feltárt több korszakú lelőhely adataira támaszkodva igyekszem körüljárni (Fábián 2004; Fábián 2006; Fábián-Serlegi 2007.), miként lehet a különböző régészeti időszakokhoz kapcsolódó települések domborzati elhelyezkedéséből és szerkezeti változásából a tó egykori vízállására, annak ingadozására és a tó-közeli területekre gyakorolt hatására következtetni. Ezen felül célom egy olyan típusú vizsgálat elkészítése, amely feltérképezi, hogy a Nagyberek peremén ugyanazon a helyen elhelyezkedő, különböző korszakokhoz tartozó települések miként illeszkedtek a tágabb környezeti képbe, a tó és a vízpart mellett milyen egyéb tényezők befolyásolták az egykori közösségeket abban, hogy településeiket a feltárások során megismert geomorfológiai környezetben hozzák létre.

Nem egy részletes, minden korszakra kiterjedő környezeti rekonstrukció elkészítése volt a célom, az elmúlt tíz-tizenöt évben különböző üledékgyűjtők területén mélyített geológiai fúrások regionális és lokális jelleggel egyaránt tettek már erre kísérleteket (Sümegi et al. 2004, Sümegi et al. 2007, Sümegi et al. 2009.). A vizsgálat a környezetrekonstrukciós kísérlet helyett sokkal inkább környezetrégészeti megközelítést alkalmazva arra irányult, hogy a lelőhely környezetét ne csak, mint a folyamatok hátterét kezeljük. A rendelkezésre álló információk alapján próbáljuk körvonalazni, hogy a környezet folyamatos változása miként befolyásolta az emberi megtelepedések rendszerét, milyen folyamatokon mentek keresztül. Ebben a környezetben a Balaton egyrészt egy olyan mértékű természetes tényező, amely jelentős szerepet játszik az ember és a környezet közötti kölcsönhatás alakulásában, másrészt természeti szerepe mellett jelentős hatást gyakorolt az egykori emberek életére, gondolkodásukra, az 
őket körülvevő táj megítélésére, így a múltban is jelentős kulturális szerepet tulajdoníthatunk neki. Nem elhanyagolható ezen felül, hogy a tó, tulajdonságai miatt, mint egy természetes „adatbázisként” nagy mennyiségű, a fizikai környezet alakulási folyamataira vonatkozó információt őrzött meg számunkra.

Természetesen tisztában vagyok azzal, hogy a kérdéskör minden tekintetben teljes körű feldolgozása és értékelése jelentősen meghaladja egy doktori disszertáció kereteit. Ennek a problémakörnek a feldolgozásához több diszciplína kutatási tevékenységének szervezett lebonyolítására, megfelelő módon feltett kérdésekre és a kapott válaszok és eredmények kidolgozott alapelvek mentén történő szintézisére van szükség. Éppen ezért munkámat nem tartom egy befejezett kutatás összegzésének, sokkal inkább tekintek úgy rá, mint egy későbbi, fentebb említett interdiszciplináris kutatási projekt egyik leendő fogaskerekére, amely megpróbálja rekonstruálni a tó viszonyaiban bekövetkezett változások és az emberi megtelepedések közötti viszonyrendszert.

A disszertáció alapvető célkitűzése, hogy megpróbáljon képet alkotni arról, miként alakult a Balaton hosszú távú vízállás tendenciája a régészeti korszakok folyamán, valamint ez hogyan hatott az emberi megtelepedés lehetőségeire az első jelentősebb, a tó természetes állapotába történ emberi beavatkozást megelőzően. Ez az alapvetés lényegében meghatározza a dolgozat időbeli keretét is. Feltételezésem szerint ez az esemény a késő római időszakban, az antik forrásból jól ismert időpontban és körülmények között került sor (Sextus Aurelius Victor, Liber de Caesaribus, 40, 9), amelynek eredményeként véleményem szerint nem csak a Balaton, hanem a teljes, Délkelet-Dunántúl természetes hidrológiai rendszere megváltozott (Serlegi 2007, 297-317; Serlegi 2009, 501-514; Pásztókai-Szeőke-Serlegi 2013, 68-79..). A római kori beavatkozás összetett kérdésének vizsgálata és részletes kidolgozása azonban már meghaladná a doktori disszertáció terjedelmi kereteit. Éppen ezért a dolgozat felső időbeli határát, és vizsgálataimat a római kori szabályozás időpontját megelőző időszakokra összpontosítom. A római kori szabályozás komplex kérdésének vizsgálatát pedig hamarosan egy önálló tanulmányban szándékozom bemutatni.

A vizsgálatok eredményeként remélhetőleg közelebb jutunk ahhoz, hogy a tanulmányozott időintervallumban a természetes állapotú tó vízállásában milyen jellegű és mértékű változások mentek végbe és miként befolyásolta ez a Balaton 
déli partvidékén megtelepedett közösségek településviszonyait. Hangsúlyozva hogy a tó vízállás változási tendenciáinak és ennek településszerkezetre gyakorolt hatásmechanizmusának megértése nem jelenti a teljes folyamat megértését, mindössze egy nagyon fontos, el nem hanyagolható információs csomag az emberi kultúra működési mechanizmusának komplex rendszerében.

\subsection{A disszertáció fóbb szerkezeti egységei}

A disszertáció elemeit logikailag összeköti az alapvető célkitűzése, egy olyan kép megrajzolása, amely bemutatja, hogyan befolyásolta a Balaton vízállásának változása a tó környékén élő közösségek megtelepedési viszonyait. A több régészeti korszak megtelepedési viszonyainak összehasonlító elemzése pedig rávilágíthat a régészeti időszakokon belüli vízállás tendenciákra, ami hozzásegíthet minket a Balaton múltbeli változási mechanizmusainak jobb megértéséhez. A múltbeli folyamatok megismerése segít a jövőben várható események előrejelzésében.

Az első, általános bevezetőt követő második fejezet célja, hogy egy kellő módon áttekintő képet adjon arról az elméleti fejlődésről, amelyen a környezetrégészet, mint az ember és környezet kapcsolatát vizsgálni hivatott kutatás az elmúlt évtizedek folyamán átment. Ennek szükségességét abban látom, hogy bemutassa azt a tudományos gondolkodásbeli környezetet, amelybe a disszertáció kutatási témája és eredményei reményeim szerint egy építőkockaként beilleszthető. Nem egy tudománytörténeti áttekintést kívánok adni, hanem felvázolni azt a gondolati fejlődést, amely elvezetett attól a felismeréstől, hogy a környezet nem az emberi történelem változatlan természetes háttere, egészen a napjaink reménybeli módon formálódó inter- és transzdiszciplináris perspektívájáig. Áttekintem azokat az elméleti lépcsőfokokat, amelyek elvezettek az újrégészet időszaka alatt a tényleges környezetrégészet megszületéséig és a hirtelen fejlődésnek induló elméleti megközelítésekig. A posztprocesszuális régészeti gondolkodás megjelenésével jelentős kritikák érték az újrégészet alapvető teóriáit és az ember valamint a környezet viszonyáról és ennek megismerhetőségéről alkotott elképzeléseit. Az értelmező régészet új elméleti irányai és a kialakuló történeti táj szemlélete megtermékenyítően hatott az ember és környezete között lejátszódó kölcsönhatások vizsgálatára. A modern 
inerdiszciplináris kutatások pedig számtalan új lehetőséget nyújtanak a természettudományi és társadalomtudományi megközelítések és módszerek összehangolásával a komplex rendszerek teljes igényű vizsgálatára.

A harmadik fejezet bemutatja azt a nagyobb területet és részeit, amelyekre a kutatás szorítkozik. Részletesen, azonos paraméterek alapján leírom az érintett kistájak jellemzőit, valamint egy bővebb összefoglalást adok a Balaton geológiai és vízrajzi sajátosságairól, kialakulásának folyamatairól. A fejezet végén rátérek arra, hogy a Balaton vízszint ingadozása miként hozható összefüggésbe a régészeti lelőhelyek jelenségeivel és ez miképpen segítheti a tó rövidebb távú vízszint változásainak rekonstrukcióját.

A negyedik fejezetben összefoglalom a Balaton vízállásváltozása és a régészeti lelőhelyek geomorfológiai elhelyezkedése közötti összefüggések kutatásának előzményeit és eredményeit az 1960-as évek végétől napjainkig.

Az ötödik fejezetben ismertetem a Baltonkeresztur-Réti-dűlő (M7/S35) lelőhely régészeti korszakait, valamint megvizsgálom a terület autópálya építést megelőző talajmechanikai fúrásainak adataiból levonható következtetéseket elsősorban a terület talajvízviszonyainak szempontjából. A kapott eredményeket összevetem a régészeti korszakok megtelepedési viszonyaival a lelőhelyen, abból a célból, hogy milyen módon lehet a megtelepedési zónák alapján a talajvíztükör ingadozásaira, illetve ezen keresztül a Balaton vízszintváltozásaira következtetni.

A hatodik fejezetben a Nagyberek területén mélyített üledékgyűjtő fúrás palinológiai elemzésének értékelését mutatom be.

A balatonkeresztúri lelőhely talajvízviszonyaiból és a korszakonkénti megtelepülések elhelyezkedéséből levonható következtetések ellenőrzésérét is igyekeztem elvégezni egy nagyobb terület korszakonkénti településrendszerének elemzésével. Az összehasonlító elemzéshez elkészítettem a kiválasztott terület térinformatikai állományát. A hetedik fejezet ennek a modell-építésnek a technikai részleteit tartalmazza.

A nyolcadik fejezet az elkészült modellbe integrált, régészeti szakirodalom alapján összeállított lelőhelyek korszakonkénti vizsgálatáról szól a modell négy statikus vízborítási értékének tükrében.

A kilencedik fejezet a dolgozat eredményeinek összefoglalását tartalmazza. 


\section{A környezetrégészet elméleti fejlődése}

\subsection{A régészet és a környezetrégészet viszonya}

A 21. századi modern tudományos kutatásban, ahogyan a hangsúly egyre inkább a kutatócsoportok összehangolt tevékenységére helyeződik, jól megfigyelhető a hagyományos diszciplináris keretek leomlása. Mi sem példázza ezt jobban, mint ennek a doktori disszertációnak a megírása. A dolgozat alapvető kérdésfeltevése a klasszikus tudományági felosztás szerint a bölcsészettudományok, azon belül a régészet tárgykörébe tartozik. Ennek ellenére az értekezés a Földtudományi Doktori Iskola keretin belül, természettudományi környezetben kerül beadásra. Ez a helyzet első pillantásra ellentmondásosnak is vélhető. Amennyiben azonban egy kicsit mélyebbre nézünk, könnyen belátható, hogy egyes régészeti kérdések tanulmányozása nem is áll túlzottan messze a földtudományok érdeklődési körétől.

Az általános felfogás szerint a régészet elsősorban a régi korok anyagi kultúrájával és tárgyi emlékeivel foglakozó kutatás (MÉK 1972, 1153.). Ezt a fajta megközelítést ugyan a régészet már régen túlhaladta, azonban elméleti fejlődését ez a kiindulópont alapjaiban meghatározta. A régészet alapvetően a leletanyagokból (tárgyak), régészeti jelenségekből (régészeti objektumok) származó információkra alapozva igyekszik összefüggéseket megragadni, amelyekből egykori emberi közösségek szociális, gazdasági és kulturális jellegére, és az ezeket befolyásoló, formáló folyamatokra következtet. Így végső soron az emberi gondolkodás és kultúra idő- és térbeli alakulásáról alkot elméletet. Azaz empirikusan felfogható és különböző szintű felbontásban vizsgálható anyagi típusú alapadatokból elméleti rendszereken keresztül társadalomtudományi eredményeket és következtetéseket generál.

A régészeti adatok közé nem csak az előkerült tárgyak, régészeti objektumok (mikroscale), településszerkezetek (mezoscale) tartoznak, hanem fontos az a tágabb világ is (macroscale), amelyben ezek a dokumentált jelenségek elhelyezkednek. Ebből adódóan a lelőhelyek tágabb, földrajzi és geológiai értelemben vett környezete már a földtudományok érdeklődésébe is beletartozik, hiszen a felmerülő kérdések már ennek módszereivel is vizsgálhatóak. Ez pedig elvezet a környezetrégészet fogalmához.

Ezen a ponton feltehetjük a kérdést, hogy mit is jelent valójában az a kifejezés, hogy környezetrégészet. Logikusan, következhetne az elnevezésből, hogy érdeklődésének tárgya az ember és környezetének vizsgálata a régészeti időszakokban (Jerem 2003, 
39.), vagy másként, célja rekonstruálni a táj egykori fizikai állapotát, amelyben az emberi közösségek a múltban éltek, gazdálkodtak (Wilkinson-Stevens 2003, 15.). Ha azonban mélyebbre ásunk az értelmezésben, egy sokkal komplexebb kép tárul elénk.

Ennek a fejezetnek a célja, hogy egy áttekintést adjon a környezetrégészet definíciójáról és elméleti fejlődéséről, a régészeten belül betöltött szerepéről és megítéléséről, valamint arról, hogy az elméleti fejlődés következtében milyen szerepe lehet az elkövetkezendő időszak kutatásaiban. Korántsem egy minden részletre kiterjedő tudománytörténeti ismertetés a cél, inkább a gondolkodásbeli és elméleti fejlődésének alakulását igyekszem megfogni.

$\mathrm{Az}$ első probléma rögtön a tudományági besorolásával kezdődik, nehezen meghatározható, hogy a környezetrégészet önálló tudomány (Renfrew-Bahn 1999, 211; Branch et al. 2005, 1.), a régészet egyik ága (Jerem 2003, 39.), vagy a régészet segédtudománya (Wilkinson-Stevens 2003, 12.). Ez a hazai és nemzetközi szakirodalomban egyaránt tapasztalható bizonytalanság egyáltalán nem véletlen. Nem kezelhetjük önálló tudományként, hiszen nincsenek önálló módszertana, saját vizsgálati eszköztára. Nem is definiálhatjuk segédtudományként, mert nem szolgáltat a régészet számára önálló paradigmák alapján alkotott eredményeket. Abban az esetben, ha mindenképpen be szeretnénk sorolni a hagyományos meghatározások sorába, akkor legközelebb talán a régészet egyik ágaként, esetleg kutatási irányként foghatjuk fel (van der Leeuw 2001, 4585; Jerem 2003, 39.). Olyan kutatási irányként, amely megteremti a kapcsolatot a régészeti adatokból és elméleti következtetésekből származó régészeti eredmények és más, az emberi kultúrákat körülvevő környezetet tanulmányozó, elsősorban természettudományos eredmények között.

A lényege talán pont ebben fogható meg, hogy a középpontjában áll az olyan, interdiszciplináris eredményeket is felhasználó, összetett régészeti kutatásoknak, amelyekben a régészeti adat és az adatokból levonható következtetések, több más tudományterület azonos súlyú eredményei mellett, a teljes kutatási tevékenységnek csak az egyik hozzáadott eleme. Véleményem szerint is napjainkban a környezetrégészetet egyfajta szintetizáló folyamatként kell értelmezni. Egy olyan folyamatként, amely segíti a különböző tudományágak, a fizikai környezet tulajdonságait és változások folyamatait előidéző tényezőket vizsgáló természettudományok és az emberi kultúra fejlődésének folyamatait vizsgáló régészettudománynak, illetve más társadalomtudományi ágak eredményeit és vizsgálati módszereit összekapcsolni. 
Feladata nem pusztán a környezettörténeti adatok régészeti adatokhoz való kapcsolása, hanem elősegítse, hogy ezek a különböző megközelítésekkel és módszerekkel dolgozó tudományágak együttesen tudják megfogalmaznia a közös kutatások alapkérdéseit. Ezt követően az eredményeiket összekapcsolva közösen, elméleti szinten tudnak válaszolni az ember és környezet közötti rendkívül komplex viszony kapcsán feltett kérdésekre. Ezzel nagyban segíti a régészet és több természettudomány összekapcsolt eredményeinek a többszintű, transzdiszciplináris kutatások komplex rendszerébe való bekapcsolódást.

Az a felfogás, amely a környezet és az ember viszonyát egy folyamatos kölcsönhatásként fogja fel, amelynek egyszerre vannak fizikai és kulturális ismérvei, a környezetrégészeti kutatásban nagy hagyományokkal rendelkező angolszász régészetben is csak hosszú, elméleti és módszertani fejlődés eredményeként alakult ki. Közép- és Kelet-Európában a régészeti gondolkodás hagyományosan elsősorban az adatok gyűjtésére és tematikus rendszerezésére, illetve kronológiai kérdésekre helyezte a hangsúlyt. Még az elmúlt évtizedekben is sokkal kisebb figyelmet szentelt a rögzített adatok és következtetések átfogó régészetelméleti keretbe helyezett vizsgálatokra. Habár az utóbbi időben egyre szélesebb a felismerés az interdiszciplináris módszerek használatára, ez általában kimerül a természettudományok asszisztenciájának igényében (Pauknerova et al. 2013, 135.). Európának ezeken a részein az egykori környezet tanulmányozása hosszú ideig a tekintélyes adatbázisok és az egykori flórára, faunára vonatkozó adatsorok létrehozására korlátozódott, azonban a környezeti kép komplex rekonstrukciójára vonatkozó átfogó elméleti kérdések hiányoztak (Smyntyna 2006, 84.).

Ezért a környezetrégészet fentebb említett modern szerepének kialakulásához vezető út és a jövőbeli alkalmazási lehetőségek megértéséhez szükség van a környezetrégészet elméleti fejlődésének rövid áttekintésre.

Azoknak a tudományágaknak a tudománytörténeti fejlődéséről, amelyek a fizikai környezet változásait tanulmányozzák, és amelyeknek az eredményeit a környezetrégészet a régészeti eredményekkel hivatott integrálni már nagy részletességgel összefoglalták (Sümegi 2003, 13-23.). Ezért itt ezeknek a legkorábbi, önálló fejlődési szakaszára nem térek ki. 


\subsection{A környezetrégészeti gondolkodás fejlődése}

A környezetrégészet alapjairól, a környezetrégészeti elemzések során alkalmazott tudományágak módszereinek leírásáról és a környezetrégészet elméleti fejlődéséről már számos összefoglaló mű készült, és érhető el az angol nyelvű szakirodalomban (Rosignol, 1992; van der Leeuw 2001; Dincauze 2000; Wilkinson-Stevens 2003; Branch et al. 2005; Rapp-Hill 2006).

A régészettudomány viszonylag hosszú történetén belül, a környezetrégészet intézményesülését, illetve magának a kifejezés használatának a kezdetét az 1950-es évekre tehetjük. Ekkor jön létre az első kifejezetten egyetemi állás. Friedrich Zeunert nevezték ki 1952-ben a környezetrégészet professzorává a londoni Régészeti Intézetben. A természettudományok jelenléte a régészetben azonban hosszabb múltra tekint vissza (Wilkinson-Stevens 2003, 18.).

George Rapp és Christopher Hill könyvében három részre osztja a környezetrégészet fejlődését (Rapp-Hill 2006, 5-20.). Az első, avagy kialakulási fázis a 19. századra és korábbra esik. Ebben az időszakban nem volt valós határ a régészet és a természettudományok között és valójában egyéni tudósok dolgoztak számos diszciplínában egymaguk. Ezek a korai kutatók első sorban Észak-Európából származtak és a felsőbb osztályokhoz tartoztak, akiknek volt ideje és módja, mintegy hobbiszerűen az egyéni érdeklődésével foglalkozni. Fontos szerepet játszottak ezen felül 19. század közepén jelentős fejlődésnek indult biológiai tudományok, amelyek elsőként kezdtek foglalkozni az élőlények fejlődése és a környezeti adottságok közötti összefüggésekkel. Ekkor született meg J.B. Lamarck adaptációs elmélete, amely szerint az élőlények adaptálódnak a környezetükhöz és ezt a szerzett tulajdonságot örökítik tovább utódaikra. Ez az időszak az evolúciós elméletek kialakulásának a kora, Charles Darwintól és Alfred Russel Wallace-tól, akik bizonyították, hogy a fajok jelenlegi kinézete egy fejlődés eredménye és a különböző fajok földrajzi elerjedése eltérő. Ennek egyik oka a külső körülmények változása, mint az éghajlat, vagy más fajok terjeszkedésére adott válasz. Nagy fontosságú felfedezés volt abból a szempontból, hogy felismerte, hogy a környezet, amit ma ismerünk, nem volt mindig ugyan ilyen. Ezt megelőzően ugyanis úgy gondolták, hogy a környezet régészeti léptékben változatlan, és mintegy díszletként hátteret szolgáltat az emberi közösségek tevékenységének. 
A második fázis az úgynevezett együttműködés időszaka. Ebben a szakaszban már a természettudósok és a régészek közösen kezdtek gondolkodni a felmerülő problémákon. Erre az időre a 19. századi polihisztorok korszaka lejárt, megkezdődött a specializálódás, elsősorban a természettudományok művelőinek körében. Egy ember már nem volt elég az összes diszciplína átlátására, összefogására. A közös munka olyan módszerek felfedezéséhez vezetett, mint például a pollen és makrofosszilia analízis, amelyek később fontos elemeivé váltak az interdiszciplináris régészeti kutatásnak.

Ebben a korszakban kezdtek hatni más társadalomtudományok elméleti fejlődésének eredményei a régészeti kutatásra. Elsősorban a szociológia és az antropológia elméletei közül kettő is jelentős hatást gyakorolt a környezetrégészet későbbi fejlődésére: a materializmus és a funkcionalizmus.

A materializmus elképzelései szerint emberi társadalom megértését elsősorban az jelenti, ha megértjük, hogy az emberek miként elégítik ki anyagi szükségleteiket. Képviselői azt vizsgálták, milyen módon szervezi egy társadalom az alapvető igényeinek kielégítését, mert szerintük ez a kiindulópontja a társadalomszervezet irányításának és meghatározója emberi társadalom fejlődésének.

A funkcionalizmust elsősorban Arthur Radlciffe-Brown és Borislaw Malinowski antropológusok nevéhez kötik, ők azonban csak ennek elsősorban antropológiai alkalmazásában jártak az élen. Malinowski elmélete szerint az igények az emberek biológiai szükségleteit jelentik. Az emberi társadalmakban valójában a kultúra helyettesítette a természetes kiválasztódást, amely egy hatékonyabb és megalapozottabb eszköze és módja az alapvető emberi biológiai igények kielégítésének. Malinowski alapvetéséből következik, hogy életünk kulturális elemei valójában a biológiai szükségleteink kielégítését szolgálják.

Malinowski azonban nyitva hagyta a kérdést, hogy ha az emberi kultúra valójában egy továbbfejlesztett biológiai adaptáció, akkor mi az oka a kultúrák változásának, átalakulásának és földrajzi diverzitásának. A nyitva hagyott kérdés megválaszolásra az érvelés következő logikus lépcsőfoka az, hogy a változás és ezzel a mindenkori adaptáció környezetileg meghatározott.

Malinowski elmélete a biológiai tényezőkről egyaránt vonatkozik az emberekre és az állatokra. Egy ponton viszont kapcsolódik egy pszichológiai megközelítéshez, amely környezetrégészeti szempontból egyértelműen összekapcsolja a környezetet és a környezetben élő emberi közösségeket. Ez a pszichológiai megközelítés a 
behaviorizmus, amely az emberi viselkedést veleszületett, környezettől stimulált válaszadásként szemléli.

Amennyiben a kulturális elemeket a válaszadásnak tekintjük, a természetes környezetet a külső kényszerítő erőnek, akkor ebből az következik, hogy az emberi kultúra a környezet által meghatározott. A kultúra nem más, mint egy a környezet által kikényszerített emberi válasz. Így a kultúra valójában egy működési mechanizmus, amely segít az embereknek beszerezni a szükségleteiket a környezetükből.

A környezetrégészet elméleti fejlődésében a következő nagy jelentőségű logikai láncszem Christopher Hawkeshoz köthető. Az úgynevezett Hawkes féle következtetési létra meghatározása alapján a régészeti adatok értelmezésének különböző nehézségi szintjei vannak. A létra alján a legkönnyebben értelmezhető szint a technológia áll. A megértésben a következő szinteken a kapcsolódó tevékenységek következnek nehézségi sorrendben, a gazdaság, szociális szervezet, politika. A létra tetején a múltbéli ideológiák helyezkednek el, amelynek megértése Hawkes szerint szinte lehetetlen. Az elmélet jelentősége abban rejlik, hogy a korábbi kutatásokhoz képest először helyezte a régészeti összefüggések megértésének folyamatába az ideológiák kutatásának jelentőségét és az interpretációs lehetőségeit a gazdasági és társadalmi elemek, így a környezeti kérdések kutatása mögé (Hawkes 1954, 155-168.).

Hawkes elméletével voltaképpen el is érkeztünk a környezetrégészet elméleti fejlődésének harmadik, másként integráló szakaszához, amely a második világháborút követően kezdődött és napjainkban is tart. Erre az időszakra általánosságban az elméletek sokrétű fejlődése volt a jellemző és vezetett el napjaink régészeti gondolkodásnak kialakulásához. Elmondható, hogy ezek a fejlődési folyamatok a régészetelméletben főként az új, elsősorban természettudományos technikák fejlődésének köszönhetőek. Talán a legfontosabb a Willard Libby által kidolgozott rádiokarbon datálás volt. Ez nem csupán forradalmasította az abszolút kronológiát, de lehetőséget biztosított arra is, hogy összehasonlítsanak különböző földrajzi elhelyezkedésű lelőhelyeket. Így a régészet egyik nagy kérdése és feladata a kor megállapítása, és az egymástól független relatív kronológiai rendszerek egymással való szinkronizálása már nem okozott többé problémát, a régészek a nagyobb, átfogó jellegű kérdések felé fordulhattak (Renfrew-Bahn 1999, 36.). Ez a szakasz volt a régészet elméleti fejlődésének időszaka Észak-Amerikában és Angliában egyaránt. 
Észak-Amerikában a korai hatvanas években megújultak a társadalmi evolúciós elméletek. Leslie White a kulturális és technológiai fejlődésben a környezet hasznosításának legenergiatakarékosabb módjára való törekvést látta. White és kutatótársai azt az elképzelést vallották, hogy létezik egy univerzális, legjobb módja a környezeti elemek hasznosításnak. White szerint a kulturális változás mögött új technológiák kialakulása áll, amelyek még hatékonyabb módon tudják kielégíteni a biológiai szükségleteket (kulturális materializmus). Egy közösség összetettsége és a fejlődése azt jelenti, hogy a társadalmak képesek növelni az energia felhasználás hatékonyságát a technológiák felhasználásán keresztül. White elmélete ugyan háttérbe szorítja az adaptáció jelentőségét, de felveti, hogy a kulturális elemek eszközként szolgálnak a társadalmaknak a természetes környezet adaptációjának leghatékonyabb módjában. Habár a kulturális materializmus alapjait White alkotta meg, maga az elmélet Marvin Harris nevéhez füződik. Harris 1964-ben dolgozott ki egy bonyolult elméletet, amely felvetette, hogy a kulturális jellemzők valójában eszközként múködnek, annak érdekében, hogy az emberek minél hatékonyabban tudják hasznosítani a környezetüket.

Ebben az időszakban kezdett egyre nagyobb teret hódítani az a nézet, hogy az emberek interakcióban vannak a környezetükkel és egyben függőségi viszonyban is. Ezt először nem is a régészet, hanem a kulturális ökológia keretei között fogalmazták meg, amelynek egyik első képviselője Julian Steward volt az 1950-es években. Steward a kulturális materializmus elméletével éppen ellentétesen, az adaptációnak nagyobb jelentőséget tulajdonítva, a technikai fejlődést a különböző környezetekhez való alkalmazkodás következményeként látja. Logikája szerint a különböző típusú környezetek adnak magyarázatot az emberi kultúrákban megfigyelhető eltérésekre. Ebben az értelemben a kulturális adaptáció nem a hatékonyság emelésével, hanem a különböző környezetek által kikényszerített technológiai fejlődési irányokkal azonos. A másik faktor, amit Steward beemelt az elméleti rendszerbe, a népességdinamika volt, amely szerinte együtt, de ellentétes ütemben (push-pull mechanism) működik a technológiai fejlődéssel.

Angliában ugyan ebben az időben nagyon hasonló folyamatok játszódtak le, a kutatók igyekeztek eltávolodni a tárgyak interpretálásától, a hangsúly a tárgyak mögött rejlő információk és nagyobb összefüggések, mint például a környezet és az emberi táradalom között meglévő interakció felé fordult. Ez pedig elvezetett annak a megközelítésnek a kialakulásához, amely az őskori közösségeket minden tekintetben 
teljesen a környezettől függőnek feltételezi, ebből egyenesen következtetve magát az őskori társadalmakat is.

A környezetrégészet szempontjából talán a legjelentősebb elméleti iskola az úgynevezett újrégészet, másként processzuális régészet volt. Az újrégészet a régészeti vizsgálatokban és a következtetések során egyaránt igyekezett átvenni és alkalmazni a természettudományokban már meghonosodott módszertani szigorúságot. Annak ellenére, hogy a későbbi elméleti irányzatok képviselői sok szempontból vitatják az újrégészet elméleteit, az elvitathatatlan, hogy olyan légkört teremtett, amelyben a gazdaság, a környezet és az emberi közösségek közötti viszony iránti érdeklődés elvezetett a környezetrégészet, mint tudományos látásmód kialakulásához.

$\mathrm{Az}$ újrégészet valójában a hatvanas évek fiatal szakembereinek, a hagyományos régészeti teóriáival való elégedetlenségéből nőtte ki magát. Többek között Lewis Binfordnak, Colin Renfrew-nak és David Clarke-nak határozott elképzelései voltak, hogy a régészetnek milyen irányba kell haladnia. Törekvésük az volt, hogy a régészetet még tudományosabbá tegyék, megfogalmazva a régészet nagy alapkérdéseit, a tudományos törvényszerűségeket, amelyek a társadalom fejlődését és szerkezetét meghatározzák.

$\mathrm{Az}$ újrégészet sokkal nagyobb figyelmet szentelt a mennyiségileg mérhető adattípusoknak. Ezen felül bevezette az ethnoarchaeologia fogalmát, amelynek során nagy hangsúllyal tanulmányozták természeti népek életét és anyagi kultúráját, ebből igyekeztek következtetéseket levonni az őskori társadalmak tárgyi hagyatékának megismerhetőségi korlátaira. További eredménye a processzuális régészetnek, a „site formation process" és a taphonómia fogalmának és elméletének fókuszba kerülése.

A természettudományokhoz hasonló tudományszemléleti törekvéseik mellett azonban több, más társadalomtudomány, főként a szociológia és az antropológia elméleti eredményeit is átemelték a régészetbe. Az egyik ilyen alapvető teória az úgynevezett „optimal foraging theory”, amely a vadászó-gyűjtögető közösségek ellátására szolgáló területek legoptimálisabb kihasználásának, mint a környezethez történő kulturális adaptációnak az elméletét fogalmazta meg. Ehhez volt hasonló Eric Higgs „site catchment analysis" elmélete, amelyet a letelepedett fölművelő társadalmak lakóhelyének megválasztása és a környezetükben lévő gazdaságilag hasznosítható erőforrások legoptimálisabb kihasználása közötti összefüggések elmélete.

Az újrégészet kétségkívül egyik legjelentősebb alakja Lewis Binford a munkáiban egyesítette a kulturális ökológiát és a kulturális materializmust. A kulturális adaptációt a 
környezet felhasználásának leghatékonyabb eszközének tartja. Elmélete szerint a társadalmi jelenségek egyben válaszok a természeti tényezőkre. A kérdésre, hogy ha az emberek a környezetüket mindig a leghatékonyabb módon használják ki, akkor miért változnak a kultúrák, Binford azzal felelt, hogy a környezeti változások hiányában a társadalmak mindig ugyan olyanok maradnának. Ebből következik, hogy az elmélet alapján a környezeti változások hatalmas szerepet játszanak a kulturális változásokban, más szóval a kultúra az emberiség extraszomatikus eszköze a környezeti adaptációra.

Binford a nyolcvanas években némileg módosította az elképzelését átvette a szociológiából már ismert a középszintű elméletet („middle range theory”). Ebben a régészeti adatokat igyekezett két lépésben a múltbéli kulturális változásokhoz kötni. Első lépésként a statikus régészeti adatoknak a környezeti változásokkal és az emberi magatartás-dinamikával való összekötését (középszint), második lépésként pedig ennek a középszintű eredménynek a régészet nagy, átfogó elméleteinek rendszerébe való beillesztését határozta meg.

Az 1980-as évek elején tűnt fel és gyakorolt egyre nagyobb hatást az úgynevezett humán ökológiai megközelítés, amelyet először 1982-es munkájában Karl Butzer alkalmazott a régészetben (Butzer, 1982).

Az 1980-1990-es években egy eltérő törekvésű régészeti szemlélet alakult ki, amely nagyban támaszkodott az újrégészet elméleti újításaira, azonban jelentős kritikákat fogalmazott meg vele szemben. Ennek a dolgozatnak nem célja, hogy átfogó módon, a régészetelmélet általános fejlődését bemutassa. Éppen ezért, a processzuális régészet időszakát követő posztprocesszuális, avagy értelmező régészet elméleti sokrétegűségét nem részletezem, csak a processzuális régészet szemléletmódjával kapcsolatos kritikákra és a környezettel kapcsolatos általános látásmódjára térek ki. A legélesebb különbség a processzuális és posztprocessuális látásmód között talán abban ragadható meg, hogy az utóbbi képviselői megkérdőjelezték a régészeti következtetések egyértelműségének létezését (Renfrew-Bahn 1999, 42.). Szerintük az objektivitás elérhetetlen, minden régészeti jelenségnek több olvasata is lehet. Ez a felfogás alapvetően szembe megy azzal a természettudományos szemlélettel, hogy a következtetéseknek egyértelműeknek és érzelmektől mentesnek kell lenniük. A posztprocesszuális elmélet képviselői a környezetrégészettel szemben az alábbi, alapvető problémát fogalmazták meg. Általánosítja azt a felfogást, hogy az ember és környezete viszonyában az emberi tevékenység és kultúra a természet-kihasználás 
hatékonyságának növelését szolgálja, és ezt tartja meghatározónak. Ebből adódóan csak gazdasági alapú hipotézisekben tud gondolkodni, más alternatív hipotéziseket figyelmen kívül hagy. Az adatok értelmezése végül ritkán megy túl a hatékonyság magyarázatán, elhanyagolja a tények megértésében a társadalmi és kulturális kontextust (WilkinsonStevens 2003, 257.).

Felrótták, hogy jelenségek funkcionalista megközelítése miatt első sorban azokkal a primer célokkal és eszközökkel számol, amiket az egykori emberek tulajdoníthattak a dolognak. Azonban minden régészeti jelenségnek lehet másod, harmadlagos jelentéstartalma, ha túllépünk az elsődleges, használati értelmezésen és társadalmi kontextusba ágyazva szemléljük azt. A posztprocesszuális elmélet támogatóinak éppen az volt a problémájuk a természettudományos megközelítéssel, hogy az minél inkább redukálni igyekszik az ideológiai, érzelmi jelentéseket, és a hideg, egyértelmű tényekre szándékozik támaszkodni. A természettudományok azonban a dolgokat csak méretük, súlyuk, fizikai reakciójuk alapján tudják vizsgálni, nem tudnak mit kezdeni a kulturálisan beágyazott jelentéstartalmakkal, értelmezési szintekkel. Véleményük szerint a környezetrégészet meghatározható történeti szemléletmódon keresztül is. Így elkerülhető a módszerek és megközelítések természet- és bölcsészettudományok közötti egyesítésének problémája, és eredeti módon, a régészettudomány keretein belül megérthetőek, magyarázhatóak a dolgok. , A kutatás, az emberi tényező elvének hangsúlyozása mellett a környezetrégészetet úgy szemléli, mint annak megértésének módját, hogyan használták az egykori környezetet az emberek. Teszi mindezt azért, hogy megértse és felidézze az egykori életet, és nem törekszik az egykori környeztetek fizikai rekonstrukciójára. Ebben a fordított helyzetben a hangsúly a fizikai környezetre gyakorolt társadalmi befolyásoláson van. A környezet elsősorban a társadalmi fejlődéshez viszonyul, és az élelem megtermeléséhez illetve a lakóhely megteremtéséhez csak másodlagosan (Evans 2003, 19.).

Ekkor alakul ki és állandósul a régészeti terminológiában a táj, a kulturális táj megnevezés, amely a környezettől elsősorban megközelítésében és felfogásában tér el. Az újrégészet környezet koncepciójával szemben a táj- tájkép felfogás sokkal inkább megfelel a fentebb leírt interpretatív történeti és kulturális megközelítésnek (Ickerodt 2006, 54-55.). A tájat egy dinamikusan fejlődő komplex jelenségként fogja fel, amelyet a fejlődése folyamán a különböző korszakokban az ember különböző kulturális folyamatokon keresztül alakított. Ezen változások egymásra épülésével, rétegződésével 
minden korszak egy „történeti tájat” épít, módosít tovább, tehát a táj, mint régészeti jelenség, minden esetben sok korszakot ölel fel, magába foglalva a különböző korszakok embereinek a tájról alkotott elképzelését (Zatykó 2011, 388.).

Fontos elem volt az ember és környezet kapcsolatával foglalkozó kutatások elméleti fejlődésében, amikor az 1970-es évek közepén a biológiatudományokban már 1935-ben A.G. Tansley által megfogalmazott ökoszisztéma elméletet R. Rappaport és A. Vayna átültették a társadalomtudományok területére is. Azt vallották, hogy az ember csak egy faj a rendszeren belül, ugyan azok a törvények hatnak rá, mint más fajokra, tehát saját fajunk az ökológia eszközeivel megismerhető. Annak ellenére, hogy ez a gondolat szemben áll a posztprocesszuális gondolkodás alapvető megközelítésével, nagy hatással volt a környezet és az ember viszonyáról való gondolkodásra. Az ökoszisztéma kibernetikus jellege vezetett ugyanis a rendszerelemzés módszerének alkalmazásához, amely kaput nyitott ahhoz a szemlélethez, amely a környezet és az ember viszonyát egy komplex rendszerként fogja fel. A rendszerelmélet széles teret engedett, hogy az empirikus valóság elemzésével átlépjenek a hagyományos tudományági határokon. Alapvetően a rendszerszemléletű megközelítés holisztikus jellegű, vagyis a rendszer egyes részelemeinek megértése nem lehetséges a teljes rendszer megértése nélkül (Moran 2010, 64-66.). Tehát a környezet és az ember viszonya sem érthető meg anélkül, hogy az egyes elemeit a maguk vizsgálati módszereivel egyenként meg ne vizsgálnánk, (a környezetet a megfelelő természettudományos az embert és az emberi kultúrát pedig a megfelelő társadalomtudományi módszerekkel) majd a rendszer egészének megértéséhez az eredményeket össze kell kapcsolni. A rendszerszemlélet beemelése a vizsgálatok közé lehetőséget biztosított a környezet és ember kapcsolatának rendszer szintű újraértelmezéséhez, amely elvezetett olyan felismerésekhez, mint a non-lineáris, dinamikus rendszerek megléte. Az első generációs, a régészetben alkalmazott kulturális rendszermodellek gyakran hivatkoznak egyenes vonalú fejlődésre, illetve előnyben részesítik az elképzelést a stabilitásról és egy feltételezett halmozódó fejlődésről, amely a növekvő komplexitás felé vezet. Így a kezdeti ökoszisztéma elméletekben egyensúlyi modelleket dolgoztak ki. Az egyensúlyi modellben a figyelem középpontjában annak a vizsgálata áll, hogy az ember milyen technikák segítségével kerül stabil, egyensúlyi helyzetbe saját környezetével. Ez a modell azonban túlhangsúlyozza a negatív visszacsatolások szerepét, és elhanyagolja a pozitív visszacsatolásokat, amelyek valójában gyorsítják a rendszeren belüli változást. Az utóbbi időkben, a modernkori 
éghajlati és környezeti változások hatására egyre nagyobb jelentőségűvé vált az emberi hatások tanulmányozása. Ennek eredményei alapján a zárt ökológiai rendszereket tanulmányozó modelleknek megkérdőjeleződött a megbízhatósága, mert az emberekhez kapcsolható visszafelé ható folyamatokat, váratlan következményeket nem tudta kezelni.

A környezetrégészeti kutatásokban nagy kötöttséget jelentenek ezek a fajta önszabályozó, zárt rendszerekről alkotott elképzelések. Ezek alapvetően megkülönböztetnek embert és környezetet. Ebben az alapjaiban hibás, koncepcionális kettős felosztásban az ember a természetes környezetre gyakorolt hatás szerepét kapta, ami pedig nem az elképzelt egyensúlyi állapot irányába, hanem annak lebontása felé tolta a rendszert.

Az utóbbi idők fizikai és természettudományi eredményei megmutatták, hogy az evolúció útvonala valójában a non-lineáris rendszerekben érhető nyomon és a rendszeren belül lévő folyamatok egymáshoz való viszonya vezet stabil, nagyjából stabil és instabil állapotok irányába. A rendszeren belüli folyamatok változása úgynevezett elágazások sorozatán keresztül foghatóak meg, amelynek során a rendszer minőségi változáson megy keresztül. Ezeknek a komplex rendszereknek az egyik legfontosabb eleme a visszacsatolások mechanizmusa, amelyek erősítik a biológiai, fizikai, vagy szociális folyamatokat. Valójában a rendszerek szerkezete, az átalakulás gyakran az önerősítő pozitív visszacsatolások eredménye, úgymint a szaporodás, együttműködés, verseny az egyéni és közösségi szinteken, bizonyos esetekben ez kialakít olyan instabil helyzeteket, amelyek az átmeneti állapotok létrejöttét erősítik (McGlade 1995, 113.).

Egyértelműen meg kell tehát fogalmazni, hogy a környezetrégészet jóval több, mint egyszerű környezetrekonstrukció. Az alapvető fizikai folyamatok szempontjából interpretálja a múltbeli emberi tevékenységet, és alapvetően járul hozzá tudásunkhoz a múltbeli emberi tevékenységek fizikailag leírható folyamataihoz, ezzel segít megérteni azokat fizikai folyamataik irányából.

Ez az alapelv akkor válik nehezebben magyarázhatóvá, amikor a további interpretációk során felvetődik, hogy mit tud mondani a természettudományi megközelítés a tevékenységek céljáról. Alapvető elvárás, hogy a tudományos kutatás és eredmény semleges és értékmentes legyen. Ezzel szemben sem a múltbeli emberi tevékenységek, sem pedig azok interpretációja nem az. Abban a pillanatban, hogy megállapítjuk, hogy a tevékenység optimális, vagy hatékonyságnövelő, máris értékítéletet mondunk, azzal, 
hogy mit tartunk optimálisnak vagy hatékonynak. De ilyen szubjektív magyarázatot a természettudomány nem ismer. Ezért a magyarázat megtalálásához a kutatók kénytelenek olyan tudományágakhoz fordulni, amelyek alkalmasabbak az alapvető társadalmi kérdések vizsgálatára, mint a szociológia, történelemtudomány, filozófia, kognitív pszichológia, kulturális antropológia.

Az, hogy a múltbéli környezeti folyamatok hogyan érintették az egykori embereket és az emberek hogyan illeszkedtek az akkori társadalmi kontextusba, rendkívül összetett és bonyolult folyamat. Ehhez el kell fogadnunk a több szempontú interpretációk érvényességét ugyan arra a jelenségre.

A tevékenységek, tudás és társadalmi értékek közötti kapcsolat és ezek társadalmi kontextushoz való kapcsolódásának megértéséhez a múltbeli közösségeknél a régészeti adatokat nem elég csupán etnográfiai evidenciákkal összehasonlítani. Meg kell érteni a tényeket saját, eredeti történeti, régészeti összefüggéseikben. Az azonos kultúrához tartozó emberek önmagukat nem csak a saját kultúrájukon belül definiálták, hanem az őket körülvevő világ részeként is (Wilkinson-Stevens 2003, 264.).

A fejezet lezárásaként talán elmondható, hogy a környezetrégészet jövője szempontjából nem jelent hosszú távú perspektívát a processzuális és posztprocesszuális elméletek és megközelítések egymással való szembeállítása. Amint láthattuk, a valóságban ember és környezet kapcsolata nem választható szét, egyazon rendszer különböző módon vizsgálható, de egymással szoros kölcsönhatásban és interakcióban lévő elemeiről van szó. A környezeti változás következtében létrejövő interakció és emberi tevékenység változást okoz a környezetben. A mód, ahogyan a környezet reagál a változásra újabb emberi tevékenységet és magatartást generál. Ez a körforgás soha nem ér véget, nem jut el az egyensúlyi állapotba és nem jelent lineáris fejlődést sem. Éppen ezért az interakciók megközelítésének legjobb módja egy olyan elméleti tér megalapozása, amelyben többféle tudományág módszereit, elméleteit és értelmezési módjait összehangolva létre lehet hozni egy adatalapú, társadalomtudományi magyarázatot. A feladat egy közös tudományos cél megfogalmazása és elérése ezen a tudományágak között létrejött integráción keresztül. Egy transzdiciplináris megközelítésre van szükség, amiben az újszerű elméletek, technológiák és módszerek együtt tudnak működni, hogy új kérdéseket fogalmazzanak meg és új módszertani és koncepcionális kereteket hoznak létre (Pauknerova et al. 2013, 139.). 
Véleményem és reményeim szerint a környezetrégészet, a fent említett felfogással és újraértelmezéssel részben betöltheti ennek az innovatív és integráló keretnek a feladatát.

Hosszútávon véleményem szerint az ilyen típusú kutatások messzire ható sikereket eredményezhetnek. Hosszabb távon gondolkodva ugyanis, nem lehet megállni a múlt egyszerű rekonstruálásánál, mert a múltbeli törvényszerűségek megértésének végső célja, hogy a minél nagyobb valószínűséggel tudjuk előre jelezni a jövőben várható folyamatokat. Abban az esetben, ha sikerül modellezni több ezer évnyi időintervallumon belül a környezet és az ember közötti interakció mechanizmusának alapvető elemeit és szabályszerűségeit, az fontos adalék lehet napjaink egyik leginkább kutatott témájának előrejelzési rendszeréhez. Ez a téma nem más, mint a jelenkori környezetre gyakorolt antropogén hatások, és azok várható, rövid, közép és hosszú távú környezeti reakcióinak modellezése. A modellalkotás azonban ebben az esetben sem állhat meg a primer környezeti következmények szintjén. Mint láthattuk a múltban, így a jelenben és a jövőben sem modellezhető az ember és környezet kapcsolata zárt rendszerként, soha nem éri el az egyensúlyi állapotot. Ebből adódóan az antropogén hatásokra bekövetkezett környezeti változásokra az emberiség válaszreakciója következik, ami újabb hatást gyakorol a környezetre, így gördítve tovább a folyamatot. A környezetrégészet lehetősége, hogy ezt a kérdést évezredes adatsorokon vizsgálhatja és megfelelő integrált módszerek alkalmazásával nagy mennyiségű adatot képes biztosítani a várható emberi és kulturális hatások szempontjából az előrejelző modellek számára. Nagy előnye lehet, hogy nem csak a környezeti elemek fizikai változóit, hanem az egyidejű emberi válaszlépések kulturális elemeit is modellezhető adatként építheti be.

Mint az látható a környezetrégészet kérdésköre már régen szakított az adaptáció, az effektivitás, a kulturális és társadalmi megközelítések problémakörével. A dolgozat következő fejezeteiben kísérletet teszek olyan kezdeti lépések megtételére, amelyek idővel egy reménybeli komplex kutatási rendszer építőkövei lehetnek. 


\section{A kutatásba bevont terület ismertetése}

\subsection{A tágabb nagytáji földrajzi környezet}

A terület (3.1. ábra) nagytáji besorolása szerint a Dunántúli-dombság területére esik. (Marosi-Somogyi 1990, 483-589; Dövényi 2010, 431-526.) A Dunántúli-dombság a Nyugat-magyarországi-peremvidék, a Dunántúliközéphegység és az Alföld között, a Balatontól délre eső heterogén jellegű tájegyüttes (Pécsi 1981, 17.).

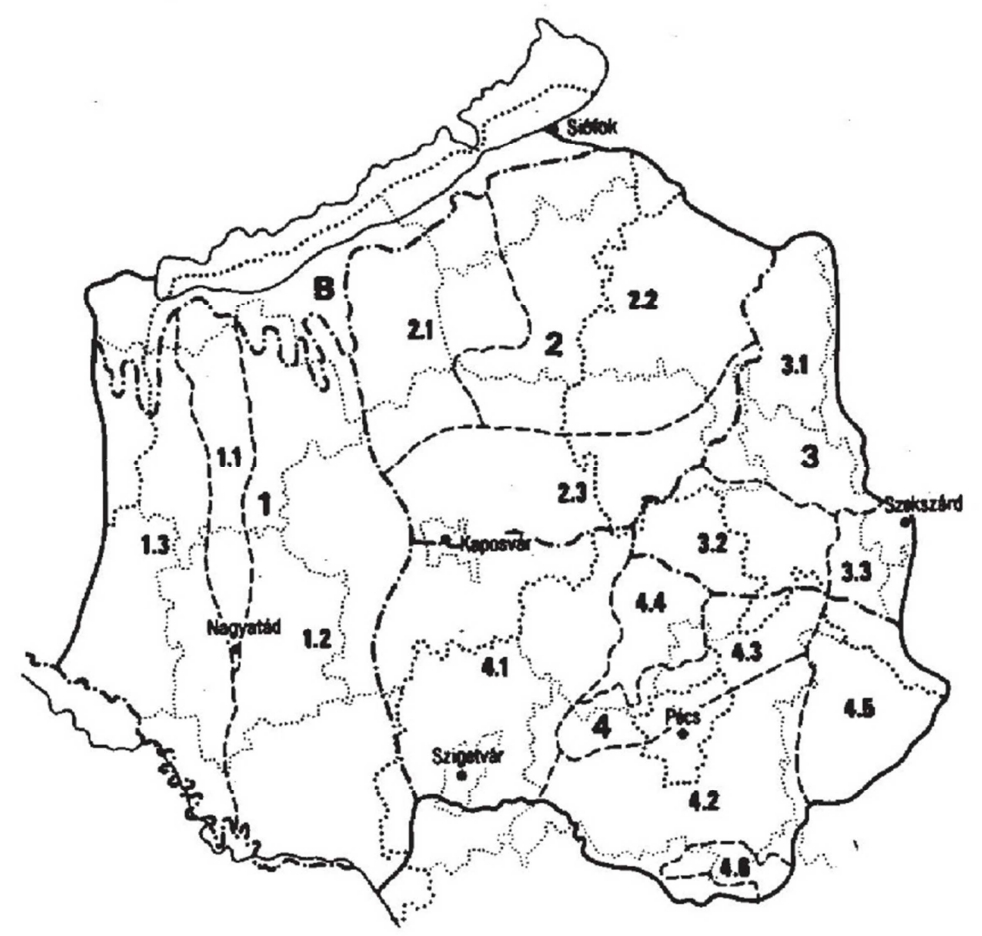

3.1. ábra. Dunántúli-dombság és részei: B: Balatoni-medence déli része; 1: BelsőSomogy; 1.1: Marcali-hát; 1.2: Kelet-Belső-Somogy 1.3: Nyugat-Belső-Somogy; 2:

Külső-Somogy; 2.1: Nyugat-Külső-Somogy; 2.2: Kelet-Külső-Somogy 2.3: DélKülső-Somogy; 3: Tolnai-dombság; 3.1: Hegyhát; 3.2: Völgység; 3.3: Szekszárdidombvidék; 4: Baranyai-dombság; 4.1: Zselic; 4.2: Dél-Baranyai-dombság; 4.3:

Mecsek; 4.4: Baranyai-Hegyhát; 4.5: Mórágy-Geresdi-dombság; 4.6: Villányihegység.

Vizsgálataim szempontjából természetesen a teljes területe nem vehető figyelembe, ezért csak egyes részeire összpontosítok részletesebben (3.2. - 3.5. ábra). Ezek a Somogyi parti sík, a Nagyberek és a Kis-Balatoni-medence kistájak, 
amelyek a Balaton-medence középtájhoz tartoznak, valamint a Marcali-hát kistáj, amely Belső-Somogy középtáj nyugati pereme (Marosi-Somogyi 1990, 483-495, 528-531; Dövényi 2010, 433-446, 471-475.).

A Dunántúli-dombság nagytáj heterogén tájföldrajzi összetételének köszönhetően változatos domborzati képpel rendelkezik, ami tükröződik rendkívüli mezo- és mikroklimatikus gazdagságában is. Szintén a változatos domborzati tagoltságának, fejlett völgyhálózatának köszönhetően bővelkedik felszíni vízfolyásokban, illetve a talajvíz mennyiségében. Ezzel szemben rétegvizekben és hévizekben a szomszédos területeknél jóval szegényebb.

Éghajlatára általánosságban jellemző, a nedvesebb szubmediterrán, szubatlanti jelleg, az Alfölddel szemben például jóval elmosódottabban jelentkeznek a kontinentális éghajlati hatások, mert a terület az óceáni, szubmediterrán és a kontinentális éghajlati hatások peremén helyezkedik el, amely visszatükröződik (Sümegi et al. 2004, 402). Ez a sajátosság tetten érhető a növénytakaróban, a növényzeti és talajmozaikok kifejlődésében is, hiszen déli és délkeleti részén szubmediterrán és nyugat-balkáni, míg délnyugaton mediterrán és atlanti flóraelemekkel találkozhatunk. A területre természetes, illetve természet közeli állapotában a zárt erdő volt jellemző, ez azonban mára a töredéknyire zsugorodott a nagyfokú erdőirtásoknak köszönhetően. Jellegzetes őshonos fafajtái a tölgy, a bükk, gyertyán és az ezüsthárs volt.

Növényföldrajzi képének köszönhetően talajtani szempontból is változatos képet mutat. Az egykori nagykiterjedésű erdők következtében a régióban elsősorban barna erdőtalajok találhatóak, amelyek azonban a nagymértékű és intenzív szántóföldi művelés hatása egyre inkább a mezőségi talaj kialakulását segíti elő (Pécsi 1981, 17-23).

\subsection{Részletesen vizsgált kistájak jellemzői}

Ebben a részben igyekszem összefoglalni a környezetrégészeti vizsgálatok által érintett, a Balaton medencéjének közelében lévő kistájakat. A területekről egységesen néhány kiválasztott kategóriában adom meg a jellemzőket, úgymint a domborzati jellemzőik, földtani jellegük, éghajlati és hidrológiai jellemzőik, valamint a jellegzetes talajtípusaik. Habár az alábbi összefoglalásban a 
paraméterek elsősorban napjaink viszonyaira vonatkoznak, ezeket a kritériumokat azért tartottam fontosnak részletesebben bemutatni, mert elsősorban ezek a paraméterek azok a természetes körülményeke, amelyek az egykori emberi megtelepedések helyét, így a régészeti lelőhelyek elhelyezkedését mindig is meghatározzák. Ezenfelül kitértem a területek jellegzetes növénytakarójára is. Bár a jelenkori növényzet nem minden esetben egyezik meg az egykori növénytakaróval, egyes őshonos fajták (fűz, szil, tölgy, mogyoró, bükk, nád és sásfélék, lápi növényzet) megléte és élőkörülményeik utalnak a terület egykori tájjellegére (Sümegi et al. 2007, 245-246).

\subsubsection{Somogyi parti sík (3.2. ábra)}

Elhelyezkedése:

A Balaton déli partja mentén, a Nagyberektől Siófokig húzódó, megközelítőleg 2-4 kilométer mélységű parti sáv.

\section{Területe:}

Nagyjából 100 négyzetkilométer kiterjedésű (Marosi-Somogyi 1990, 491-495; Dövényi 2010, 439-442.).

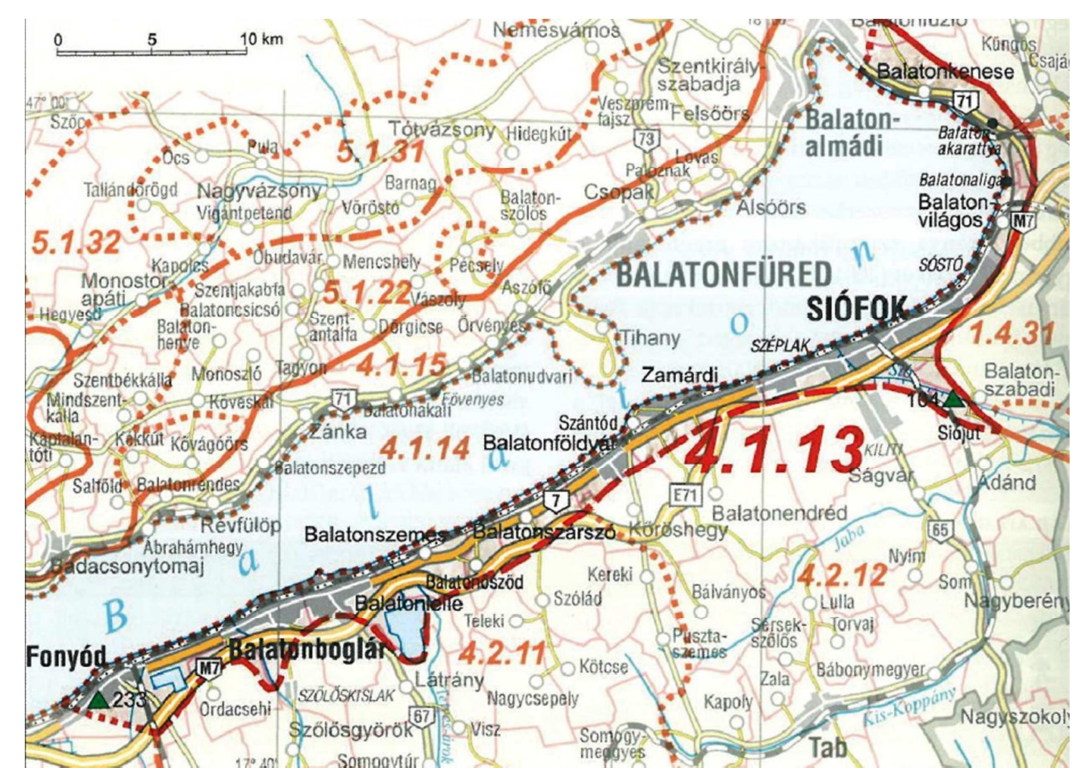

3.2. ábra. Somogyi parti sík 


\section{Domborzat:}

A tó partjának közeléig futó meridionális hátak előterében húzódó domblábi lejtős síkok jelentik. A tó partjáig kifutó, a meridionális hátak között húzódó meridionális patakvölgyek tölcsérszerű kiszélesedései a felöltődés helyszínei, ezeket a napjainkban is jórészt vizenyős területet nevezik berkeknek.

A meridionális hátak tópartig kifutó végeit a Balaton vize alámosta, így ezek magas falakként keretezik helyenként a part menti síkot. A partfalak és a víz széle között húzódik az a parti sáv, amely a szabályozások előtt egymás mögött elhelyezkedő parti turzások rendszere volt. Napjainkra ezt a területe szinte teljesen feltöltötték és beépítették (Marosi-Somogyi 1990, 491-495; Dövényi 2010, 439-442.).

\section{Földtani jelleg:}

A medence bazaltvulkanikus maradványai mellett, a terület nagy része a megsüllyedt pannoniai homokra és agyagra települt prebalatoni hordalékkúp anyagából formálódott. Az alluviális part menti sávon murvával kaviccsal kevert homokréteg terül el, helyenként deflációs eredetű lepelhomokkal elfedve. A berkekben tőzeg, lápi mész, lápi agyag található (Marosi-Somogyi 1990, 491-495; Dövényi 2010, 439-442.).

\section{Éghajlat:}

Éghajlata mérsékelten meleg, a csapadékviszonyokat alapjaiban határozza meg, hogy a mérsékelten nedves és a mérsékelten száraz zónák határán húzódik (Marosi-Somogyi 1990, 491-495; Dövényi 2010, 439-442.).

\section{Hidrológia:}

A Balatont tápláló patakok a Nagyberektől, a Sió-csatorna kifolyásáig tartó partszakaszon érik el a tó partvonalát. Siófoktól keletre egyetlen betorkolló vízfolyás sem található. A patakok azonban az év nagy részében kis vízmennyiséget szállítanak, csak tavasszal és nyár elején van nagyobb vízhozamuk. A talajvíz jellemző mélysége Balatonföldvártól nyugatra általában 2 méter körüli, míg keletre néhol a 4 méteres mélységet is eléri. A rétegvizek 
vízhozama általában közepesnek mondható (Marosi-Somogyi 1990, 491-495; Dövényi 2010, 439-442.).

Növényzet:

A nagyfokú beépítettség miatt napjainkban a természetes ártéri jellegű növénypopulációból, mint a vékony káka és a tengeri szittyó nagyon alacsony százalékban van jelen. Szintén a beépítettség miatt a part menti bokorfüzesek a füz-nyár ligeterdők szigetszerűvé alakultak. Nagyobb nádasok, magassásos állományok az üdülőövezet határán túl maradtak meg, azonban ezeket a részeket az utóbbi időkben az autópálya nyomvonalának kialakítása tizedelte meg (Marosi-Somogyi 1990, 491-495; Dövényi 2010, 439-442.).

\section{Talajok:}

A kistáj vízparti részein lápos réti talajok, és telkesített síkláp talajok vannak, míg a löszös üledékkel borított hátsági felszíneken mészlepedékes csernozjom, csernozjom barna erdőtalajok, és barna földek alakultak ki (Marosi-Somogyi 1990, 491-495; Dövényi 2010, 439-442.).

\subsubsection{Nagyberek (3.3. ábra)}

Elhelyezkedése:

A Nagyberek a Somogyi parti sík nyugati végétől a Boglári-háttól, a Marcali-hát keleti lejtőjéig tart, dél felé a mai partvonaltól megközelítőleg 30 kilométer mélységig a belső-somogyi hordalékkúpba benyúló öblözet.

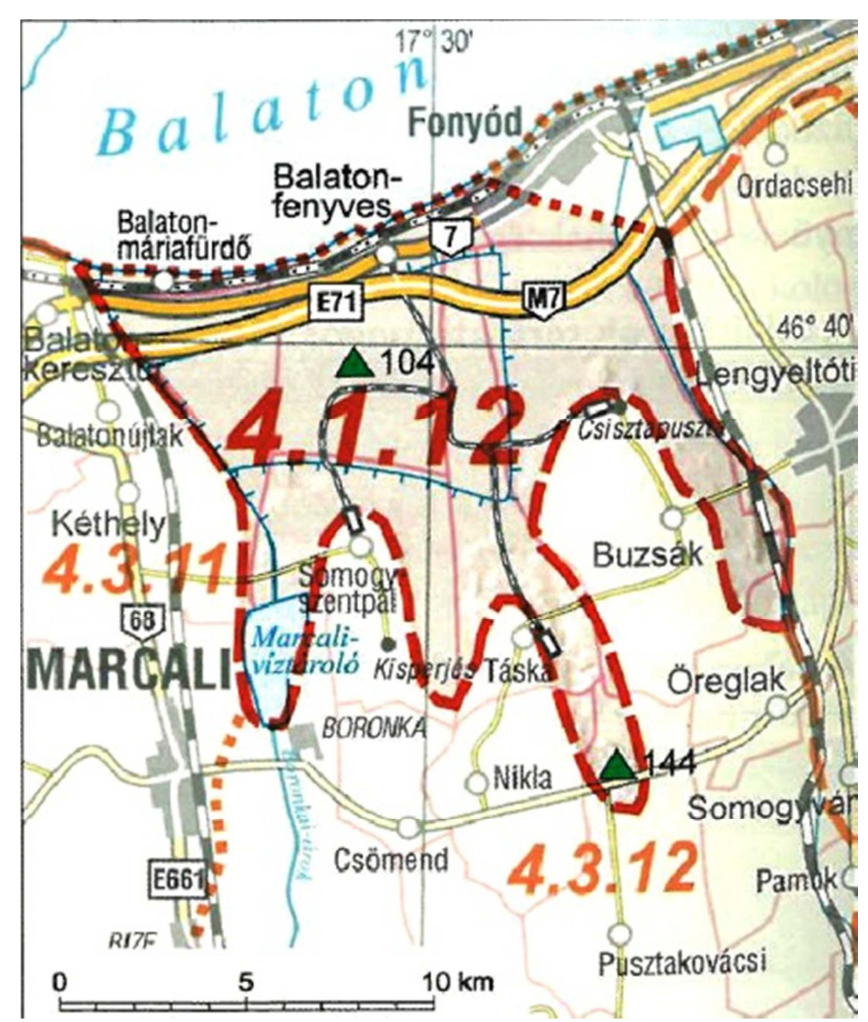

3.3. ábra. Nagyberek 


\section{Területe:}

Kiterjedése valamivel több, mint 140 négyzetkilométer (Somogyi-Marosi 1990, 487-491; Dövényi 2010, 436-439.).

\section{Domborzat:}

Az öblözet területe általában sík, csak a pereme körül fordulnak elő magasabb lépcsők. Alapjában felszíne sík, csak alacsonyabb turzásgátak váltakoznak ovális lápteknőkkel (Somogyi-Marosi 1990, 487-491; Dövényi 2010, 436-439.).

\section{Földtani jelleg:}

Az öblözetet egykor kitöltötte a Balaton vize. Ez a szétterített prebalatoni hordalékkúp kavicsos, murvás homokanyaga mellett más tavi üledékeket, iszapos, agyagos, homokos lerakódásokat is eredményezett. Ebből az üledékből formálódtak a turzásgátak is, amelyek szép lassan elzárták az öblözetet a tótól, aminek eredményeként időnként pangóvizes állapot vált jellemzővé. Ilyenkor nagy mennyiségű tőzeg, lápi mész és különféle lápi és réti talajok képződtek (Somogyi-Marosi 1990, 487-491; Dövényi 2010, 436-439.).

\section{Éghajlat:}

Éghajlata mérsékelten meleg, a csapadékviszonyokat alapjaiban határozza meg, hogy a mérsékelten nedves és a mérsékelten száraz zónák határán húzódik (Somogyi-Marosi 1990, 487-491; Dövényi 2010, 436-439.).

\section{Hidrológia:}

Valójában az egész terület ártérnek tekinthető, amelyet napjainkban is vsak egy kiterjedt vízlevezető és csatornarendszer képes szabályozott viszonyok között tartani. A betorkolló vízfolyások vízhozama éves viszonylatban alacsony, időnként tavasszal, illetve nyár elején növekszik meg. Jelentős terület pufferszerepe is vízrajzi szempontból. A talajvíz szintje az egész területen magas, mindenhol 2 méteren belül van. A rétegvizek mennyisége elhanyagolható (Somogyi-Marosi 1990, 487-491; Dövényi 2010, 436-439.). 
Növényzet:

A Nagyberek növényzetét egykori öblözet jellegéből adódóan főleg nádasok, különböző típusú sások és rendkívül változatos lápi és réti növényvilág jellemzi. Néhol előfordulnak keményfa-ligetek, ezek nagyrészt nemesnyár, akác, erdei és feketefenyő telepítések (Somogyi-Marosi 1990, 487-491; Dövényi 2010, 436439.).

\section{Talajok:}

Az egykori öblözet talaját első sorban lecsapolt síklápi talajok alkotják, amelyeket a Balaton felé humuszos homoktalajok öveznek. A déli részen található magasabb lépcsők homokos üledékén agyagbemosódásos barna erdőtalajok képződtek. (Somogyi-Marosi 1990, 487-491; Dövényi 2010, 436-439.).

\subsubsection{Kis-Balatoni-medence (3.4. ábra)}

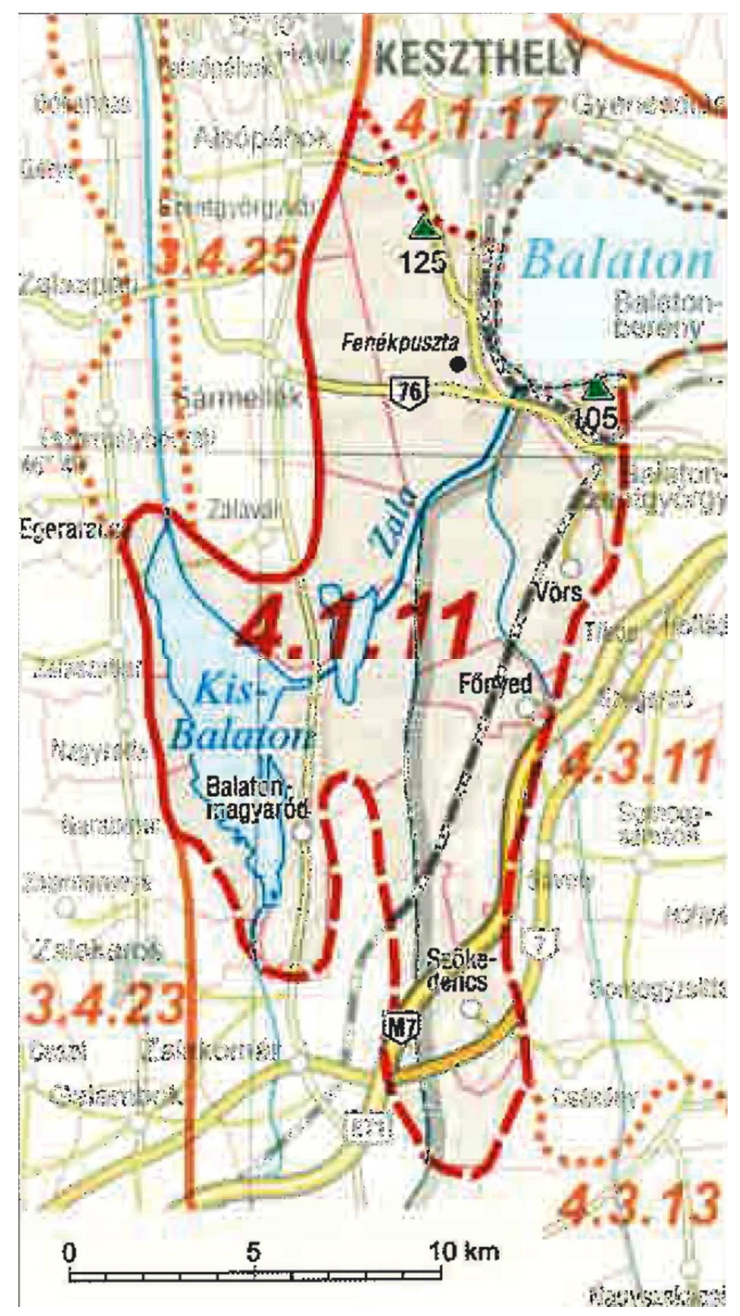

Elhelyezkedés:

A Balatontól délnyugatra húzódik, a Somogysimonyi- és Sávolyi-völgyön keresztül mintegy 10 kilométer hosszan nyúlik be a Byugat-Belső-Somogy homokos hordalékkúp felszínébe (Marosi-Somogyi 1990, 483-487; Dövényi 2010, 433-436.).

Területe:

Megközelítőleg 150 négyzetkilométer kiterjedésű medence (Marosi-Somogyi 1990, 483-487; Dövényi 2010, 433436.). 


\section{Domborzat:}

A Kis-Balaton a balatoni süllyedék délnyugati része, a tótól a fenékpusztai Castrum hát választja el, amelyet a Zala-folyó medre tör át. Dél felé homokos hordalékkúpok határolják. A Castrum-háttal párhuzamosan a futóhomokkal fedett, szintén a Zala-folyó által keresztülvágott meridionális Balatonmagyaródihát ékelődik bele a területébe (Marosi-Somogyi 1990, 483-487; Dövényi 2010, 433-436.).

\section{Földtani jelleg:}

Területe a tó természetes állapotában hozzá tartozott a Balatonhoz, amelynek bizonyítéka a kiterjedt tőzegtelepek, lápföldek, lápi meszek. A területébe ékelődő meridionális hátak futóhomokkal fedettek (Marosi-Somogyi 1990, 483-487; Dövényi 2010, 433-436.).

Éghajlat:

Az éghajlatát alapjaiban határozza meg, hogy a mérsékelten meleg és mérsékelten hűvös éghajlati öv határán helyezkedik el, csapadékviszonyaira a mérsékeltem nedves karakter jellemző (Marosi-Somogyi 1990, 483-487; Dövényi 2010, 433436.).

\section{Hidrológia:}

A területnek mérsékelt vízfeleslege van, a nagy vízhozamú időszakok főleg tavasszal jellemzőek. Kiterjedt ártéri területekkel rendelkezik, belvízmentesítését napjainkban csatornahálózat biztosítja. A talajvíz-tükör magasan, 2 méteren belül van, rétegvízben az ellátottsága közepesnek mondható (Marosi-Somogyi 1990, 483-487; Dövényi 2010, 433-436.).

Növényzet:

A kistájra leginkább a nyílt növényi társulások jellemzőek, főként a nádasok, télisásosok, láprétek, ártéri mocsárrétek jellemzőek. Jóval kisebb százalékban vannak jelen a ligeterdők, elsősorban fűz, kőris, kőris-éger, tölgy-köris-szil ligeterdők jellemzőek (Marosi-Somogyi 1990, 483-487; Dövényi 2010, 433-436.). 


\section{Talajok:}

Medence jellegéből adódóan területére elsősorban a lápos réti és síklápi talajok jellemzőek. A magasabb térszíneken harmadidőszaki üledékeken agyagbemosódásos barna erdőtalajok valamint barnaföldek képződtek (MarosiSomogyi 1990, 483-487; Dövényi 2010, 433-436.).

\subsubsection{Marcali-hát (3.5. ábra)}

Elhelyezkedés:

A Kis-Balaton süllyedéke és a Nagyberek között déli irányban, mintegy 50 kilométer hosszan húzódó dombvonulat (MarosiSomogyi 1990, 528-536; Dövényi 2010, 471-475).

\section{Területe:}

A kistáj kiterjedése valamivel több, nagyjából 300 négyzetkilométer (Marosi-Somogyi 1990, 528-536; Dövényi 2010, 471-475).

\section{Domborzat:}

A hát a belső-somogyi hordalékkúpot osztja két részre. Északi része a tópart közelében kezdődik, a déli vége ellaposodva simul bele a hordalékkúp átlag magasságába. A hát felszínét a szerkezeti vonalak mentén formálódott hordalékkúpok, és a Balaton felől hátravágódó völgyek, valamint a völgyek közötti hátak formaegyüttese jellemzi. Lejtői közepes, vagy gyenge hajlásúak, csak az északi, Balaton felé eső oldal meredekebb (Marosi-Somogyi 1990, 528-536; Dövényi 2010, 471-475).

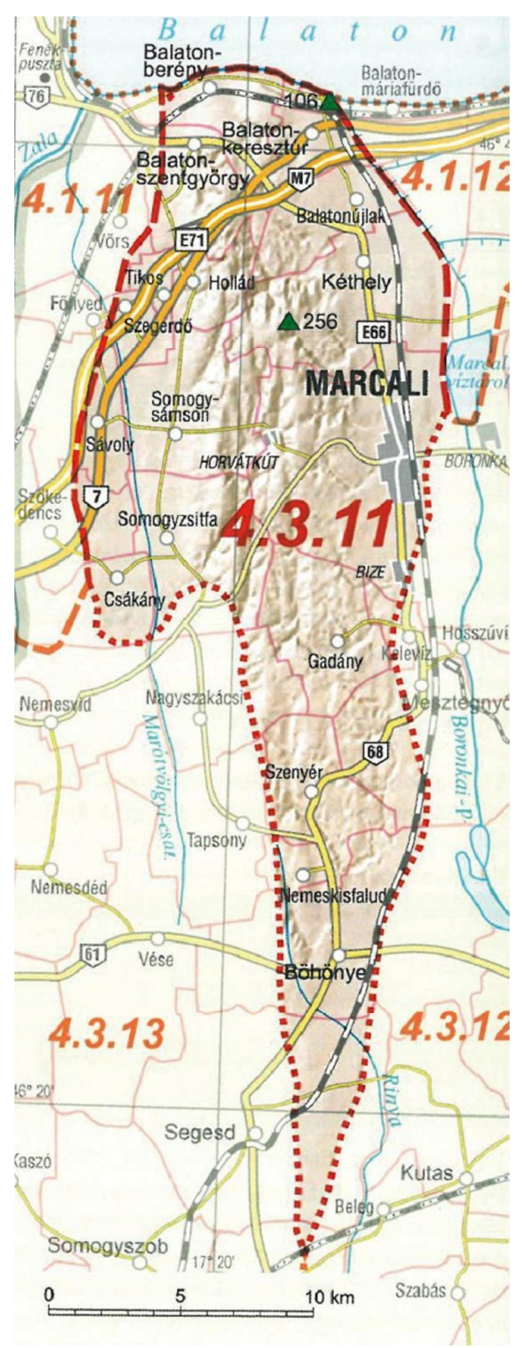

3.5. ábra. Marcali-hát 
Földtani jelleg:

A hátat pannon homok, és agyag, valamint pliocén kori keresztrétegzett homok alkotja. Ezek nagyrészt fedve vannak murvás, folyóvízi üledékekkel és vastag löszös üledékkel. Ez alatt anyaga megegyezik a belső-somogyi hordalékkúp anyagával, ami bizonyítja, hogy a kiemelkedése előtt a hordalékkúp része volt (Marosi-Somogyi 1990, 528-536; Dövényi 2010, 471-475).

Éghajlat:

Mérsékelten meleg és mérsékelten nedves klimatológiai jellemzőkkel rendelkezik (Marosi-Somogyi 1990, 528-536; Dövényi 2010, 471-475).

\section{Hidrológia:}

A területnek jelentős vízfeleslege van, a lefolyási viszonyok alapján vízfolyásai viszonylag ritkán száradnak ki, nagyobb vízhozammal azonban csak a tavaszi, kora nyári időszakban rendelkeznek. A talajvíz szintje a terület nagy részén 4-6 méter között található, míg mélyebb völgyekben 2 méteren jelentkezik. Ezzel szemben a magasabb térszíneken előfordulhat, a talajvíztükör 10 méter alatt található. A rétegvizek mennyisége nem jelentős, de artézi vizekben gazdag (Marosi-Somogyi 1990, 528-536; Dövényi 2010, 471-475).

\section{Növényzet:}

A kistáj növényzetileg a Nyugat-balkáni flóratartomány Somogyi flórajárásába tartozik. Jellegzetes erdőtársuéásai a gyertyános-bükkös, a gyertyános-tölgyes, és a mohos tölgyesek. A patakvölgyek mentén éger- és fűzlápok is kifejlődhetnek (Marosi-Somogyi 1990, 528-536; Dövényi 2010, 471-475).

\section{Talajok:}

Szinte az egész területet löszös, illetve alluviális üledékeken képződött bemosódásos barna erdőtalaj. Emellett megtalálható kis százalékban lápos réti talajok és öntéses réti talajok is (Marosi-Somogyi 1990, 528-536; Dövényi 2010, 471-475). 


\subsection{A Balaton}

Napjainkban a Balaton egy délnyugat-északkeleti irányban, 77 kilométer hosszan elnyúló tó. A Balaton jelenlegi kiterjedése és partvonala a 19. század második feléig tartó szabályozási munkálatok eredménye, amelyek során drasztikusan csökkentették a természetes vízszintet. Ezeknek az intézkedéseknek az eredményeképpen állandósult a napjainkban jól ismert - a természetes állapottól eltérő - balatoni kiterjedés és partvonal.

A tó fejlődéstörténetével számos tanulmány foglalkozott. Már a legkorábbi tanulmányok Lóczy Lajos (Lóczy 1913, 617), László Gábor (László 1913, 567.) és Cholnoky Jenő (Cholnoky 1918, 11-22.) munkái a 19. és 20. fordulóján megállapították, hogy a Balaton vízállása, területi kiterjedése időszakonként jóval meghaladta a mai viszonyokat. A tópartot kísérő turzások, szinlők és tőzegvastagság-vizsgálatok alapján jutottak erre a következtetésre. Fontos eredménye ezeknek a kutatásoknak az a megfigyelés, hogy a tó természetes állapotában csekély mértékű vízszintemelkedés esetén is elönti a déli partot kísérő meridionális völgyek torkolatát, valamint a Nagyberek területét, így ezek a tó természetes öbleivé válnak (3.6. ábra).

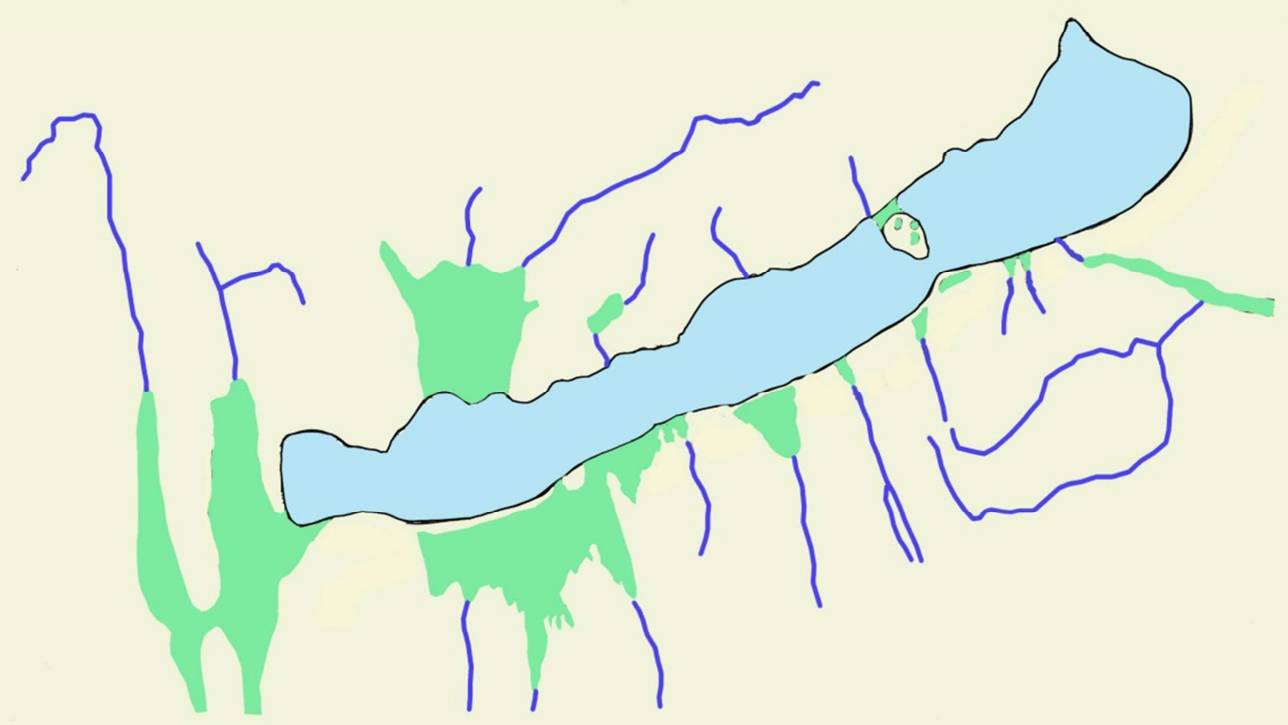

3.6. ábra. A Balaton legnagyobb kiterjedése László Gábor rekonstrukciója alapján 


\subsubsection{A Balaton geológiája}

A Balaton medencéje két nagyobb, neotektnikusan is aktív geológiai egység határán helyezkedik el, északnyugati irányban a lassan emelkedő Dunántúli-középhegység, délkeleti irányba pedig a lassan süllyedő Pannonmedence közötti vonalon.

A tó fejlődéstörténetét vizsgáló kutatások során a tómedencébe mélyített fúrások tanúbizonysága szerint a területén a Balaton kialakulását jóval megelőzően a pannon beltó húzódott. A fúrások mintegy 8-10 méter mélységben érték el a felső pannon rétegeket. Ez a tó azonban nem tekinthető a Balaton elődjének (NagyBodor-Cserny 1998, 360.).

A modern Balaton geomorfológiailag négy részmedencére osztható, a keszthelyi, a szigligeti, a szemesi és a siófoki medencékre valamint ehhez csatlakozik a Kis-Balaton süllyedéke. Ez utóbbi, annak ellenére azonban, hogy látszólag szervesen a tóhoz tartozik, mind létrejöttének időpontjában, és módjában, mind geológiai fejlődéstörténetében különbözik a többi medencétől (Lóczy 1913; Tullner-Cserny 2003, 216.).

A Balaton északi részén szilur, permi, triász, miocén, pliocén és negyedidőszaki formációk azonosíthatóak, míg a déli oldalon pliocén és negyedidőszaki képződmények dominálnak. A teljes területen százalékos arányban a legelterjedtebb formációk a késő pannon üledékekkel - mészkő, homok, agyag együtt előforduló negyedidőszaki képződmények, mint a pleisztocén lösz, diluviális, alluviális és folyami üledékek.

A Balaton medencéjét és magát a tavat számos tényező együttes hatása alakította ki, amelynek kezdete megközelítőleg a Würm végére, Kr.e. 15-16 ezer évvel (Sümegi et al. 2007, 242.). A legújabb kutatások azt mutatják, hogy a Balatonmedence az említett tektonikai törés mentén, a felső pleisztocén időszakában, a tektonikai tevékenység következtében kialakuló medencéket deflációs és eróziós hatások mélyítették tovább (Nagy-Bodor-Cserny 1998, 360; Tullner-Cserny 2003, 219.). A részmedencék vízzel való feltöltődése nem egy időben történt, a megnövekvő csapadék és a felszíni hozzáfolyások eredményeként nyugatról kelete felé egyre később következett be. A Siófoki részmedence csak a késő 
pleisztocén legvégén került vízborítás alá. Ennek a fokozatosságnak a vélhető oka valószínúleg az, hogy a nyugati részmedencékhez kapcsolódik a teljes vízgyűjtőterület nagyobbik része. Későbbiekben, egy rövid időszakban a nyugati, keszthelyi részmedencében mocsári állapotok alakultak ki, amely kelet felé egyre később jött létre és egyre rövidebb ideig tartott (Tullner-Cserny 2003, 234). A tavi abrázió hatására a medencéket elválasztó földhátak fokozatosan leromlottak, létrehozva ezzel a ma ismert Balaton látszólag egységes tómedrét. A mára már megcáfolt korai geomorfológiai vizsgálatok alapján, a részmedencék egyesülése már a pleisztocén folyamán végbement (Lóczy 1913; Marosi-Szilárd 1981, 2227.).

Az utóbbi évtizedek paleolimnológiaia kutatásai viszont azt valószínűsítették, hogy a részmedencék egyesülésére csak fokozatosan, a holocén folyamán került sor (Nagy-Bodor - Cserny 1998, 361; Tullner-Cserny 2003, 219; Jakab et al. 2005, 407). A legújabb komplex vizsgálatok bizonyították, hogy ez már a holocén legelején végbe ment (Sümegi et al. 2014, 76.)

\subsubsection{A Balaton vízrajza és üledékviszonyai}

A Balaton egységes vízfelszíne 600 négyzetkilométer kiterjedésű, a vízmennyisége megközelítőleg 2 köbkilométer. Átlagos vízmélysége 3,35 méter. A tó Zala-folyóval közös vízgyűjtője megközelítőleg 5200 négyzetkilométer (Tullner-Cserny 2003, 216-218).

A tó vízbevételét a felszínére hulló csapadékon kívül 30 állandó és 20 időszakos vízfolyás táplálja, amelyek közül a legnagyobb vízhozamot a Zala-folyó biztosítja. A mederben lévő víz mozgására, a tó sekélysége miatt jelentős hatást gyakorol a szél. A hullámok magassága elérheti az egy métert is hosszuk pedig a 7-10 métert. Az uralkodó északnyugati szél következtében szélsőséges esetben olyan úgynevezett álló hullám is kialakulhat, amelynek következtében a siófoki medencében a víz szintje egy méterrel is magasabb lehet, mint a keszthelyi medence vízállása (Tullner-Cserny 2003, 218; Dövényi 2010, 445.).

A számos tényező hatásaként, mint a part menti területek eróziója, az eutrofizáció

a Balaton feltöltődési folyamata elég jelentős. Az üledékfeltöltődés sebességét 300 éves periódus alapján vizsgálva azt lehet megállapítani, hogy az egész tóra 
vetítve ez átlagosan 0,6-0,8 milliméter évente. Ez a ráta azonban a nyugati részen, a keszthelyi részmedencében elérheti a 1,5-1,7 millimétert évente, a Zala-folyó által behordott üledékek lerakódása következtében. Rendszeres a szél keltette hullámzás miatt az iszapos üledék áthalmozódása is (Tullner-Cserny 2003, 216217.). Az üledék vastagsága az északi part mentén a legnagyobb, a Balatonban uralkodó áramlási viszonyok következtében ezen a részen iszap, míg a déli oldalon inkább a homok rakódik le. A tó átlagos üledékvastagsága 5 méter, azonban az üledék alatti rendkívül változatos mederfelszín miatt a valós vastagság 1,5 és 8 méter között is változhat (Jakab et al 2005, 408.).

\subsubsection{A Balaton vízháztartása}

A jelenlegi Balaton vízháztartását alapvetően négy tényező határozza meg. A csapadék (650 milliméter), a párolgás (870 milliméter), a hozzáfolyás (880 milliméter) és a lefolyás (640 milliméter) (Dövényi 2010, 445). Minthogy napjainkban is a tó vízbevétele és a párolgás mértéke elsősorban az időjárás, ezen keresztül pedig az aktuális klímaviszonyok függvénye (3.7. ábra), ezért az emberi beavatkozás a vízszint kontrolálásába csak a levezetésnél lehetséges. Ennek okán épült a siófoki zsilip1863-ban, amelyet később többször átépítettek, kapacitását megemelték. A tó vízszintjének megfelelő keretek között tartása rendkívül fontos

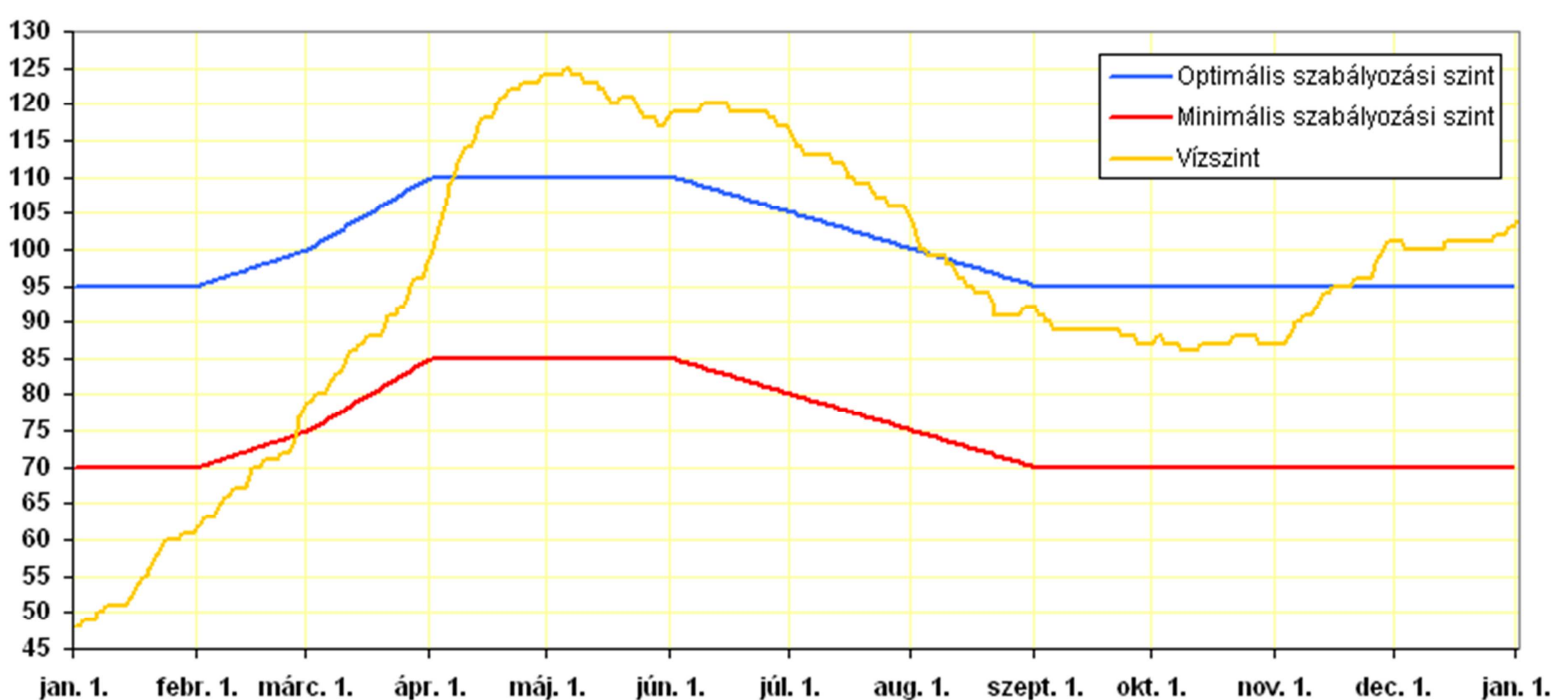

3.7. ábra. A Balaton szabályozási határértékei és a tényleges vízszint alakulása 2013-ban.

(forrás: http://www.kvvm.hu/balaton/lang hu/vizszintb.htm) 
gazdasági, turisztikai és partvédelmi kérdés, ugyanakkor rendkívül összetett és a beavatkozásokra érzékenyen reagáló folyamat. A jelenlegi szabályozás értelmében a tó vízszintje elvileg a siófoki vízmérce null-pontjához viszonyított (103,41 mBf), egy, az év szakaszától függő 0,7-0,85 (104.16-104,31 mBf) méteres minimum és egy 0,95-1,1 (104,36-104,51 mBf) méteres maximum szint közötti sávban ingadozhat.

Természetes állapotában azonban a Balaton vízállását pusztán a klimatikus tényezők határozták meg, így a 19. századi szabályozást megelőző időszakban határozottan szélsőségesebb vízszintingadozásokkal számolhatunk (Jakab et al. 2005, 407).

A vízszintingadozások nagy mértéke mellett, a tó vízháztartásában fontos tényező, hogy természetes állapotában alakja és partvonala is jelentősen megváltozik, mert elönti a déli parti meridionális völgyeket és a Nagyberek területét, így ezek a részek a tó sekély, nyílt vízzel borított öbleivé válnak. Ezzel pedig megváltozik a tó felülete, kiterjedése, amely hatással van elsősorban a párolgás mértékére (Szesztay 1959, 193.). Ez az állapot az újkori védművek hiányában már a mai mesterségesen rendkívül alacsonyan tartott üzemvízszint maximumnál (104,5 mBf) alig 0,5 méterrel magasabb vízállás estén kialakulhat. A tó felülete ebben az esetben a mai másfélszeresére, 900 km²-re növekszik. Ahhoz, hogy a Balaton kiterjedése a mai kétszeresére, azaz 1200 km²-re növekedjen, már egy újabb, 5 méteres vízszintemelkedésre van szükség. A $110 \mathrm{mBf}$ vízszint kialakulása azonban olyan nagy mértékű tótérfogat, ezzel együtt a vízmennyiség növekedésével jár együtt, amely csak egy hosszú ideig tartó rendkívül hűvös és csapadékos időszakban állhat elő. A tó vízháztartási értékei alapján (Szesztay 1959) ez az 5 méteres (105-110 mBf) intervallum, amelyben a tó természetes vízszintje a holocén időszak nagy részben ingadozhatott, tartósan kialakuló vízállása 106-107 mBf körül lehetett (Sümegi et al. 2007, 251).

\subsubsection{A Balaton hatása az emberi megtelepedésre}

Az 1990-es évek végén meginduló megelőző feltárások, amelyet az M7 autópálya nyomvonalába eső számos lelőhely megmentése hívott életre felhívta a figyelmet 
arra, hogy az egykori települések geomorfológiai helyzete és a tó természetes partvonala között jelentős összefüggés lehetett. A nyomvonalba eső nagy számú lelőhely annak köszönheti előkerülését (Bondár et al. 2000, 91-114; Honti et al. 2002, 3-36; Honti et al. 2002, 3-70; Honti et al. 2007, 7-70.), hogy az autópálya nyomvonala a tó mai partvonalával párhuzamosan, a jelenlegi parti településhálózattól néhány kilométeres távolságban fut. A természetes állapotú tó öblökkel tagolt partvonala mentén elhelyezkedő településeket az öblök megközelítőleg észak-déli partvonalára nagyjából merőleges nyomvonal érintette (3.8. ábra). A valamikori öblök helyén napjaink mesterségesen szabályozott vízszintje és a rendszeres szivattyúzás mellett is elmocsarasodott területek, az úgynevezett berkek találhatók (Tóközi-Berek, Szemesi-Berek, Ordai-Berek, Nagyberek).

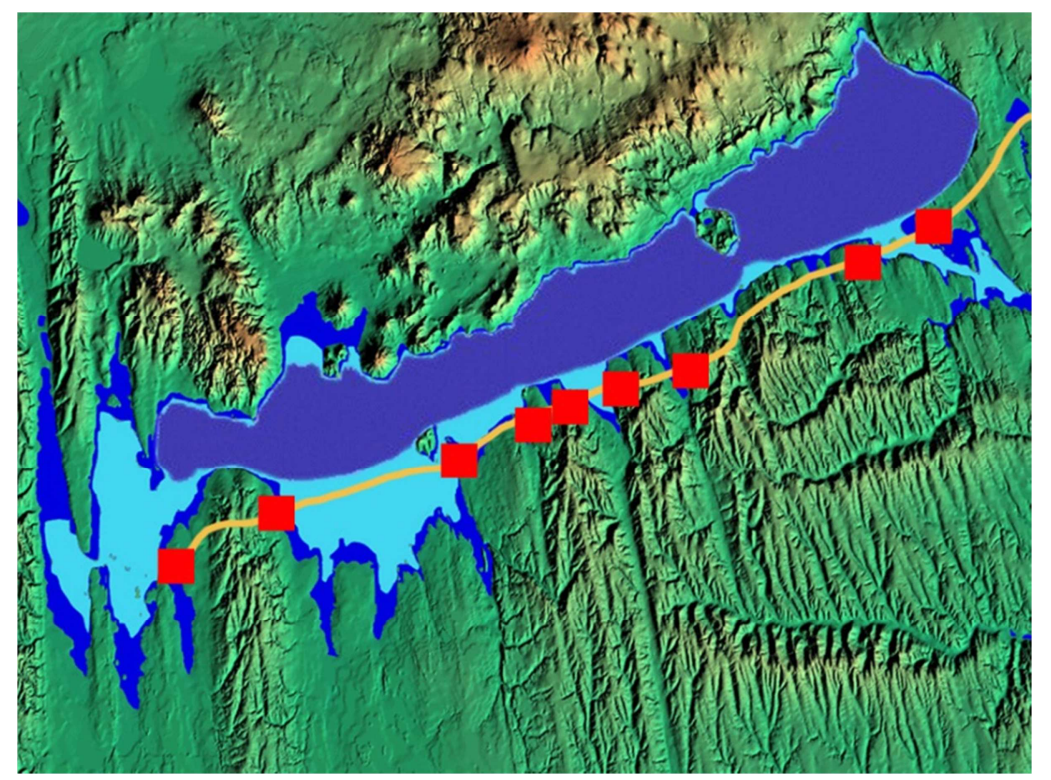

3.8 ábra. A Balaton elvi vízkitöltési modellje, a természetes öblöket keresztező autópálya-nyomvonallal és a potenciális lelőhelyek elhelyezkedésével (az ábra alapja: Tímár et al. 2010, 1.ábra)

Egy esetleges átfogó környezetrégészeti vizsgálatok szempontjából legfontosabb lelőhelyek az egykori öblök között húzódó löszös domboldalakon helyezkednek el. A Balaton mindenkori vízállása, a tófelület nagysága és ennek a talajvízviszonyokra gyakorolt hatása meghatározza a löszhátakon az emberi megtelepedésre alkalmas területek kiterjedését és ezek gazdasági hasznosíthatóságának módját. A Balaton parti lelőhelyeken összességében a 
neolitikumtól egészen a késő középkorig tartó időszakból megtalálhatóak voltak az emberi megtelepedések nyomai. Bár régészeti korszakok szerint különböző eloszlásban, de a lelőhelyek nagy részén számos időszak egymást követő települései is feltárásra kerültek. Ez az azonos helyeken észlelhető településkoncentráció arra utal, hogy a természetes állapotú tó közelében meglehetősen korlátozottak voltak a megtelepedésre megfelelő területek mind a települések létesítése, mint az eltartásuk szempontjából.

A löszhátakon feltárt, különböző korszakú települések elhelyezkedésének szempontjából az egyik legfontosabb tényező a domboldalak vízállásfüggő talajvízviszonyainak alakulása. A tófelület növekedésével megemelkedik a talajvíztükör szintje. A Balaton déli partja mentén, közvetlen vízparti településekről nem beszélhetünk, mert a tó viszonylag kis vízmélysége miatt a part közeli területek elmocsarasodtak. Az öblök között húzódó löszhátakon csak víz közeli településekkel számolhatunk. Ez azt jelenti, hogy a települések a tó közeli domboldalakon mindig olyan övezetben helyezkedtek el, amelyet a tó rövid távú vízállás-ingadozása közvetlenül nem befolyásolt. A letelepülő emberek olyan területeket szálltak meg, amelyeken a tároló vermeiket, földbe mélyített házaikat, sírjaikat nem veszélyeztette a tó évszakos vízállás-ingadozása által befolyásolt talajvíztükör-mozgás, ugyanakkor a település vízellátását biztosító kutakat, víznyerő helyeket nem kellett túl mélyre ásni a talajvízszint eléréséhez. Más szóval a települések a domboldalnak azt a részét foglalták el, ahol a talajvíztükör mélysége mind a két feltételnek egyszerre eleget tett. Fontos szempont lehetett ezen felül, hogy a nyílt vízfelület, mint természetes közlekedési és szállítási útvonal valamint élelemforrás, elérhető közelségben legyen (site catchment). Amennyiben a település élete alatt egy hosszabban tartó száraz időszak következett be, a talajvízszint csökkenése miatt kiapadhattak a telep vízellátását biztosító kutak, a nyílt víztükör túl messzire kerülhetett a településtől. Tartósan emelkedő tóvízszint esetében pedig, a tároló vermek talajvíz hatása alá kerülhettek, a telep körüli szántóföldek, legelők vizenyőssé, használhatatlanná válhattak. Mind a két esetben várható az emberi közösségek környezeti változásokra adott reakciója, amely a változás mértékétől függően lehetett a település súlypontjának eltolódása vagy a telep teljes felhagyása. Így a különböző korú régészeti kultúrák megtelepedési viszonyai egy lelőhelyen, 
azonos geomorfológiai környezetben rávilágíthatnak az adott időszak a talajvíztükör szintjére, ezen keresztül a Balaton vízállásviszonyaira és az időszak klimatikus jellemzőire is.

A megtelepedés időbeli hosszára, a településszerkezetben bekövetkezett változások fázisainak elkülönítésére a régészeti tipológia és a zárt régészeti kontextusból származó radiokarbon adatok együttes értelmezése adhat lehetőséget, amellyel egy régészeti kultúrán belüli, rövidebb időintervallumú változások is tetten érhetők. Ennek következtében a környezet- és klímatörténeti kutatások sok esetben több régészeti korszakot is átívelő általános tendenciákra vonatkozó megállapításait rövidebb szakaszokra lehet osztani.

A régészeti objektumok tengerszint feletti elhelyezkedése, mélysége, funkciója valamint a Balaton vízszintváltozásának hatására elmozduló talajvíztükör közötti összefüggések megfigyelése már korábban is elvezetett ahhoz a felismeréshez, hogy a régészeti jelenségek alapján rekonstruálható a Balaton korszakonkénti vízszintje (Bendefy 1968; Bendefy 1970; Bendefy 1972; Bendefy-V. Nagy 1969; Füzes-Horváth 1971; Sági 1968a; Sági 1968b; Sági 1970; Sági 1971; Sági-Füzesi 1973; Simonyi 1969.). Ezen keresztül pedig a geológiai módszereket kiegészítve a tó rövidebb idejű vízszint változása. A következő fejezetben ennek a kutatásnak az összefoglalása következik. 


\section{A Balaton vízállásváltozásának régészeti kutatása}

\subsection{Az 1960-70-es évek kutatásai}

Mint azt már a harmadik fejezetben említettem, a Balaton történeti korú vízszintváltozásainak vizsgálata elsősorban földtani érdeklődésű kutatóktól indult ki (Lóczy 1913; László 1913; Cholnoky 1918.). Ebben az időszakban a régészeti összefüggésekről, a tó közelében lévő régészeti lelőhelyek geomorfológiai helyzetéről és az egykori emberek életére gyakorolt hatásáról kevés szó esett, a kíváncsiságuk elsősorban a Balatonnak, mint természeti jelenségnek szólt. A régészeti kapcsolat kimerült néhány jelentősebb felfedezés értelmezése kapcsán. Jó példa erre a századfordulón Kuzsinszky Bálint által a siófoki parti turzás közelében talált falak esete, amelyet Kuzsinszky a római kori zsilip maradványainak tartott. Ez a felfedezés és feltételezés napjainkig is eltartó vitát generált. Ennek legtermékenyebb időszaka az 1960-as évek vége és az 1970es évek eleje volt, amikor két kutató, a régész Sági Károly és a geodéta, geológus Bendefy László között zajlott vita éveken keresztül a különböző folyóiratokban megjelent publikációik oldalain (Bendefy 1968; Bendefy 1970; Bendefy 1972; Bendefy-V. Nagy 1969; Sági 1968a; Sági 1968b; Sági 1970; Sági 1971; Sági-Füzesi 1973). A siófoki zsilip és a római kori Balaton viszonyai körül kirajzolódott ellentétes nézőpontok ütköztetése mellett azonban ez az időszak, amikor először szenteltek nagyobb figyelmet a földbeásott régészeti objektumok mélysége és a balatoni vízállás által meghatározott talajvízszint közötti összefüggésnek.

Ezek a munkák a korszak méréstechnikai színvonalának megfelelően - a nagypontosságú, háromkoordinátás, GPS alapú helymeghatározás hiányában - a jelenségek szintezési és geodéziai bizonytalanságai miatt számos kérdéses elemet tartalmaznak. Tovább nehezítette a korszak kutatóinak munkáját a rendelkezésre álló adatok alacsony száma. Ezen felül problémát jelentett a szedimentológiai rétegsorok pollen zónákon alapuló datálásának és a régészeti - önmagukban is bizonytalan - relatív kronológiai időszakkok összehangolása. A következtetéseik bizonytalanságát tovább növelte, hogy nem vették figyelembe a terület süllyedéses folyamatait (Sümegi et al. 2014). A süllyedési folyamatok figyelmen kívül hagyása egy-egy régészeti objektum fenékszintjének pontszerű magassági 
adataira alapozott vízszint rekonstrukciós kísérletek esetében számos hibát rejt magában. Természetesen a ma rendelkezésre álló geodéziai műszerek, számítógépes kapacitás és térinformatikai szoftverek, a radiokarbon datálás lehetősége és több száz hektárnyi feltárt terület régészeti információinak birtokában nem nehéz észrevenni a 40 évvel ezelőtti kutatásokban rejlő hibalehetőségeket. Éppen ezért a fentebbi összegzést nem Sági Károly és Bendefy László munkásságának a kritikájának szántam, hanem a célom mindössze annyi volt, hogy felhívjam a figyelmet a bennük rejlő bizonytalanságra. Megfigyelhető, hogy a Balaton történeti korú vízállásának említésekor, sok esetben még ma is az ő adataikat használják a régészeti és más tudományágak szakirodalmában. A Balaton környékének környezetrégészeti kutatása esetében azonban sokkal nagyobb annak a szemléletnek a jelentősége, hogy a két kutató munkássága felhívta a figyelmet arra, hogy a régészeti jelenségek vizsgálata és a régészeti időrend korrelációja a vízszintváltozás tendenciáival tovább finomíthatja a geológiai eredmények időbeli felbontását a térképi ábrázolások megjelenése előtti időszakból.

A következőkben igyekszem összefoglalni, hogy Bendefy László és Sági Károly a rendelkezésükre álló információk alapján milyen következtetésekre jutottak (4.1. ábra).

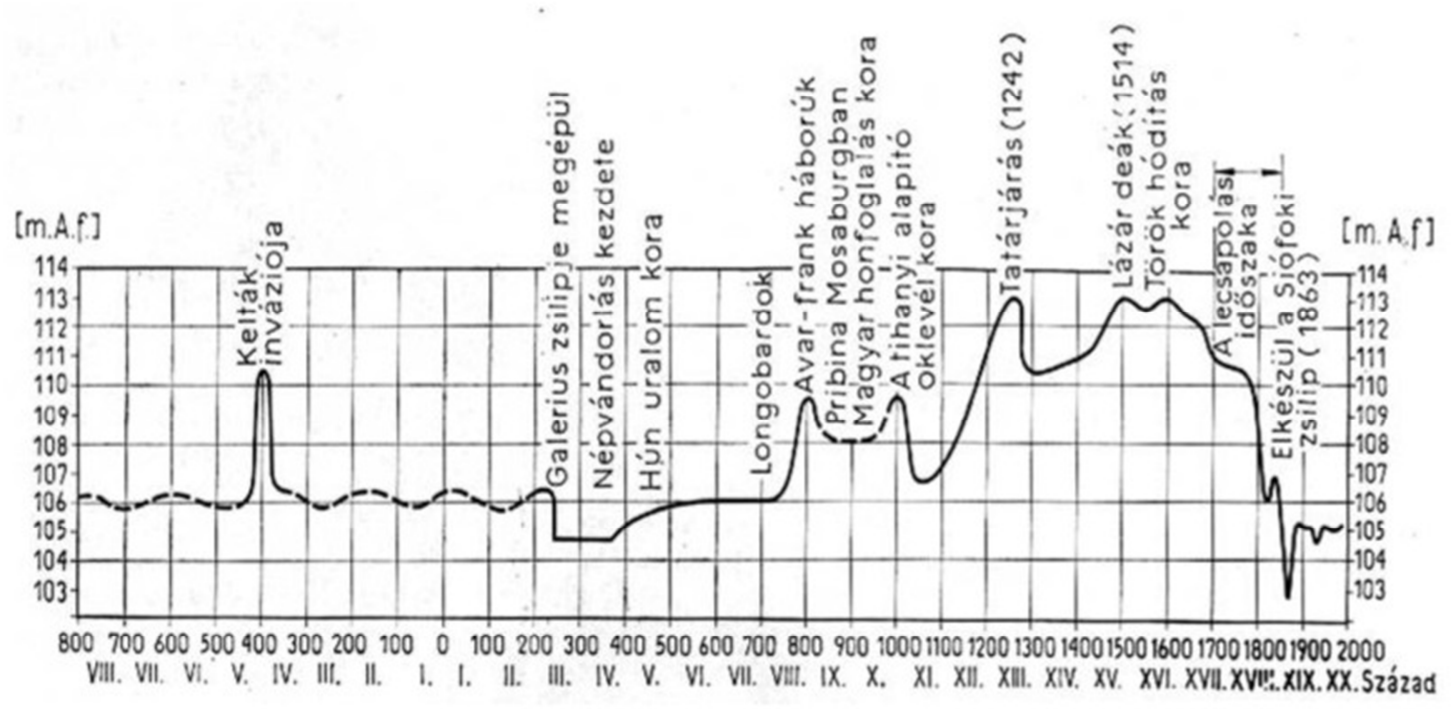

4.1. ábra. A Balaton Bendefy László által rekonstruált vízszintingadozása

(Bendefy - V. Nagy 1969, 1.51. ábra) 
A publikációikban a tengerszint feletti adatokat mind a ketten a régészeti szakirodalomban szokásos Adriai-tenger feletti magasságban adták meg (mAf). A dolgozat további fejezeteiben azonban nagymértékben támaszkodom a megelőző feltárások régészeti geodéziai adataira, amelyek Balti-tenger feletti értékekben vannak rögzítve. $\mathrm{Az}$ adatok számának nagyságrendi különbsége miatt célszerűbbnek láttam a régi adatok átszámolását balti magasságra (mAf - 0,675 $\mathrm{m}=\mathrm{mBf}$ ), így a dolgozat további részeiben a tengerszint feletti magasságok minden esetben balti szintben (mBf) értendők.

A legkorábbi időszak vízállásával kapcsolatban Sági Károly, Lóczy Lajos és Zólyomi Bálint megfigyeléseire hivatkozott, akik a Keszthelyi-öbölben két tőzegréteget figyeltek meg $(97,2$ és 99,6 méteres tengerszint feletti magasságban). A kettő között kagyló és csigahéjakban gazdag iszapos réteg húzódott. Sági Károly ezt a felső tőzegréteget Zólyomi által meghatározott pollenadatora támaszkodva a mezolitikum időszakával azonosította. Ennek alapján egy nagyon alacsony vízszintet határozott meg. Véleménye szerint a mezolit leletanyag azért hiányzik a Balaton partvidékéről, mert a telepeket az egykori vízpartján a későbbi vízszintemelkedés során a Balaton elborította (Sági 1968b, 442.). Ezt az elképzelést azóta sem cáfolta meg a kutatás, ma is elfogadják Sági Károlynak ezt a véleményét (Bánffy 2008, 154.).

A régészeti objektumok és a talajvízszint közötti összefüggések tanulmányozása kapcsán azt az elméleti alapot követte, hogy egy adott régészeti korszak földbeásott objektumainak fenékszintje nem érhette el a talajvíztükör szintjét. A módszer hibája, hogy csak a talajvízszint maximumának, így a tó vízállásának felső értékére nézve ad információt. Hozzátehetjük ehhez, hogy a feltárt telepen belüli kutaknál, abban az esetben, ha sikerül megfigyelni a nyugalmi vízszintre jellemző vasas kiválást a kút gödrének oldalán, akkor a talajvíztükör minimumértékére nézve is kapunk támpontot, hiszen a kutak esetében pont az volt acél, hogy elérjék a talajvíz szintjét (Sümegi et al. 252.).

A neolitikum időszakára, a Kis-Balatonban húzódó Zalavár-Hosszúsziget neolit gödreinek szintezési adatai alapján Sági arra a következtetésre jut, hogy a tó vízszintje a korszakban nem lehetett magasabban, mint napjaink szabályozott vízállása. Idézi Csalog József medinai (Tolna megye) megfigyeléseit, amely szerint 
a neolitikumra keltezhető objektumok fenékszintje alapján a Balaton egykori vízállása a mainál alacsonyabban lehetett (Sági 1968b, 442.).

Ugyan erre az időszakra Bendefy közelebbről meg nem határozott és meg nem nevezett „neolit kori telepek és temetők” tengerszint feletti magassága alapján magas, legalábbis a mainál jó egy méterrel magasabb vízszintet valószínűsít (Bendefy 1968, 257.).

Kora rézkorban Sági szerint a vízszint szintén alacsony volt. Megállapítása során Kalicz Nándor szóbeli közlésére hivatkozik, aki Fenékpuszta közelében (Halászrét) tárt fel egy rézkori objektumot, amelynek alja 105,7 méter tengerszint feletti magasságon volt és közel fél méter talajvíz gyűlt benne össze.

A késő rézkorban, a balatonszentgyörgyi vasútállomás közelében feltárt péceli kultúra idejére keltezett (badeni időszak) gödör fenékszintje (105,3 m) alapján szintén alacsony vízszintet valószínűsít. Ezt erősíti szerinte a fenékpusztai vasútállomás mellett 106,5 méter magasságon lévő neolit és kora rézkori telepek gödreinek fenékszintje is, ezek pontos értékét azonban nem adta meg. A telepet a későbbi korszakokban a Balaton teljesen elmosta (Sági 1968b, 443.).

A bronzkor elejére Sági németországi példákra támaszkodva (Schwabedissen 1958, 30, 35) magas vízállást feltételez, amelyet pontosabban, tengerszint feletti értékben, nem határozott meg. Véleménye szerint a „bronzkor későbbi szakaszában” újra alacsony vízállás következett, Csalog medinai megfigyelései alapján.

Az őskor későbbi szakaszai esetében, a kora és késő vaskor időszakát, illetően arra a következtetésre jutott, hogy nem lehetett a mainál lényegesen magasabb vízállás, de maga is elismeri, hogy erre az időszakra kevés adattal rendelkezik (Sági 1968b, 442-443.).

Ezzel szemben Bendefy a bronzkor folyamán magas vízszintet valószínűsített, egy Fenékpusztán, a késő római tábor mellett, a tőzegréteg alatt feltárt, meghatározása szerint cölöpökön álló halászkunyhó alapján. Az építményt bronzkoriként említi, azonban a bronzkoron belül nem adta meg pontosabban a korát. Az építmény padlószintjét 107,5 méteres magasságban rekonstruálta, és ebből, a hullámzás magasságával is kalkulálva 106,3 méter körül határozta meg a tó korabeli vízszintjét. A bronzkor későbbi szakaszában Bendefy újabb 2 méteres vízemelkedést valószínűsített, aminek bizonyítékát abban látta, hogy a tihanyi 
bronzkori földvártól északra véleménye szerint a bronzkorban egy árkot alakítottak ki. Érvelésének alapja, hogy csak magas vízállás esetén szűkül le a félszigetre vezető földnyelv annyira, hogy azt érdemes legyen egy árokkal keresztülvágva szigetté alakítani. Úgy számolt, hogy ehhez legalább 108,3 méteres vízállásnak kellett bekövetkeznie. A késő vaskor időszakában „morfológiai jegyekre” hivatkozva Bendefy megközelítőleg két méteres vízszintingadozást feltételezett, amely a szárazabb években 106-106,5 méteres szintig süllyedhetett, míg csapadékosabb időszakokban elérhette a korábbi, késő bronzkori 107,8-108,3 méteres szinte is (Bendefy 1968, 257-258.).

A Dunántúl római uralmának első háromszáz évére Bendefy szerint ugyan ez az alacsony vízállás a valószínű, és ezzel magyarázza a római kori lecsapolási munkálatokat a Kr.u. 3. század legvégén (Bendefy 1968, 258.).

Ezzel szemben Sági kora császárkori vízszinttel kapcsolatban egy, a „fenékpusztai vasúti sorompóhoz vezető út északi oldalán”, a homokbányában feltárt sír adataira támaszkodott, aminek az alja 104,6 méteres tengerszint feletti magasságban volt (MRT1 1966, 88.). Mint leírja, a talajvíz sem a sír feltárásakor, illetve logikusan a temetés időpontjában sem jelentkezett. Ebből a mai szabályozott szint vagy az alatti alacsony vízállásra következtet erre az időszakra is. A későbbi császárkort illetően két, Alsóörs és Balatonalmádi között talált, Kuzsinszky által feltárt téglabéléses sír mélységadataira támaszkodik. A sírok Kuzsinszky által megfigyelt mélységére és a megállapításaira alapozva véleményét Sági a tó vízszintjét a Kr. u. 4. században a mainál is alacsonyabbra valószínűsíti. Összefoglalva azt a következtetést vonja le, hogy a Balaton vízszintje a mezolitikum után megnövekedett, de a számára rendelkezésre álló adatok szerint nem emelkedett a mai szabályozott szintnél lényegesen magasabbra A római kori lecsapolási munkálatokat Sági szerint nem indokolták a korszak klimatikus viszonyai és vízállása, így véleménye szerint ezek a munkák a Mezőföld területén, a pannoniai úthálózat zavartalan működésének biztosítására irányultak. (Sági 1968b, 443-444.).

A két kutató között a legintenzívebb vita a római kori lecsapolás kérdésében bontakozott ki. A római kort követő időszakokra jelen dolgozat témája nem terjed ki, ezért a két kutató erre vonatkozó kutatásait és eredményeit nem tárgyalom. A Balaton történeti vízállásának vizsgálata kapcsán említett többi 
kutató főként Sági Károly és Bendefy László vitájához kapcsolódóan szóltak hozzá a témához, elsősorban a népvándorlás és kora középkori időszakot érintve (Simonyi 1969, 260-262; Füzes-Horváth 1971, 491-497.).

\subsection{Az utóbbi évtized kutatásai}

Az 1960-1970-es évek régészeti összefüggésű balatoni vízállás kutatásai után az érdeklődés a téma iránt a kétezres évek első évtizedében, az M7 autópálya megelőző régészeti feltárásai kapcsán merült fel újra.

Ugyan már a megelőző feltárások időszaka alatt, de még az előző néhány évtized kutatásainak összegzéseképpen látott napvilágot az Environmental Archaeology in Transdanubia (EnvArch 2007.) címü összefoglaló kötet. A munka kapcsán a Balaton környéki, illetve más dunántúli területek régészeti kutatási eredményeit és ugyan ezeken a területeken végzett környezettörténeti mintavételezések kiértékelését és környezetrekonstrukciókat szerkesztettek egy kötetbe. A munkában a kis-balatoni régióban, a Kis-Balaton rehabilitációs munkák kapcsán elvégzett régészeti feltárások (Évezredek 1996) és a közelükben mélyített környezettörténeti fúrások kiértékelésének összefoglalása mellett, a Balaton-felvidék, a Somogyi-dombság, az Alpokalja, a Devecseri-síkság, a Mezőség és Hahót-völgy, régészeti és környezettörténeti összefoglalása szerepel. Ez utóbbi környezeti viszonyairól és ezek településhálózati összefüggéseiről már 1995-ben jelent meg egy kisebb összefoglalás Szőke Béla Miklóstól (Szőke 1995, 13-34.).

Az M7 autópálya feltárásaihoz közvetlenül kapcsolódó munkák a kétezres évek elején jelentek meg, amelyekben a lelőhelyek régészeti ismertetése mellett már a régészeti anyaggal kapcsolatos interdiszciplináris kutatások is helyet kaptak, többek között a tó vízállásával kapcsolatos vizsgálatok is. Sümegi Pál és szerzőtársai készítettek átfogó régészeti geológiai és környezettörténeti munkákat (Sümegi et al. 2004, 399-420; Sümegi et al. 2007, 241-253.). A geomorfológiai elemzésekhez vizsgálataik során űrfelvételeket, légifotókat, történelmi fényképeket topográfiai felméréseket, illetve talajfúrások kiértékeléseit is felhasználták. Jelentősége, hogy a palinológiai, makrofosszíliai és malakológiai elemzések alapján megrajzolt paleovegetációs környezet rekonstrukciója mellett a fúrások eredményeire, valamint néhány régészeti 
objektumban feltárt jelenség értékelésére támaszkodva igyekszik rekonstruálni a Balaton vízállását a különböző korszakokban.

A kutatások kimutatták, hogy a pleisztocén időszak végén kialakult a részmedencékben vízborítás, de ezek együttes kiterjedése sem érte el a mai tó méretét. A részmedencék közötti küszöböket a korai holocén során önti el a tó, az ekkor létrejövő egységes Balaton a mai szabályozott tónál nagyobb kiterjedésű volt. A komplex vizsgálatok azt valószínűsítik, hogy ekkoriban a tó vízszintje 105,3-106,3 méteres tengerszint feletti magasságban volt. Habár a vízszint a vízbevétel és a párolgás mértékében jelentősen, akár egy métert is ingadozhatott, a neolitikum, a rézkor és a bronzkor jelentős részében ez lehetett a tó jellemző vízállása. Ekkor kiterjedése a 800-900 négyzetkilométert is elérhette.

Jól azonosítható változás a késő bronzkor végén, kora vaskor elején következett be. Ennek bizonyítékát szolgáltatta az Ordacsehi-Kistöltés lelőhelyen feltárt 2 méter mély árok, amely 119,3 méteres szintről indulva egészen 105,3 méterig lejtett, elérve az egykori vízpartot. Az árok közvetlen kapcsolatát a nyílt víztükörrel az árok tölcsérszerűen kiszélesedő végén jól azonosítható a parti hullámverés nyomai bizonyították, ami arra utal, hogy a tó vízszintje az árok kialakításának korában, a késő bronzkorban, ebben a magasságba volt. Az árok betöltésének üledékeiben azonban egészen 107 méteres szintig eutrof tavi üledéket lehetett kimutatni, az árok oldalán, pedig a hullámverés nyomai voltak azonosíthatóak. Ebből következően a szedimentológiai és malakológiai adatok jól bizonyítják a tó 2 méteres vízszintemelkedését a késő bronzkor, kora vaskor határán.

A régészeti feltárások során előkerült kutak oldalában, a pangó víz által előidézett a vasas kiválások vizsgálata alapján arra a következtetésre jutottak, hogy a római uralom első századaiban a talajvíztükör mélyen volt, következésképpen a Balaton vízállása is alacsony volt, ami a népvándorlás korára, a Kr.u. 5-6. századra egyértelműen megváltozik, a talajvíztükör és a tó vízszintje megemelkedik. Az összegyűjtött adatok alapján rekonstruálták a Balaton feltételezett kiterjedését a különböző időszakokban (4.2.-4.3. ábra). 


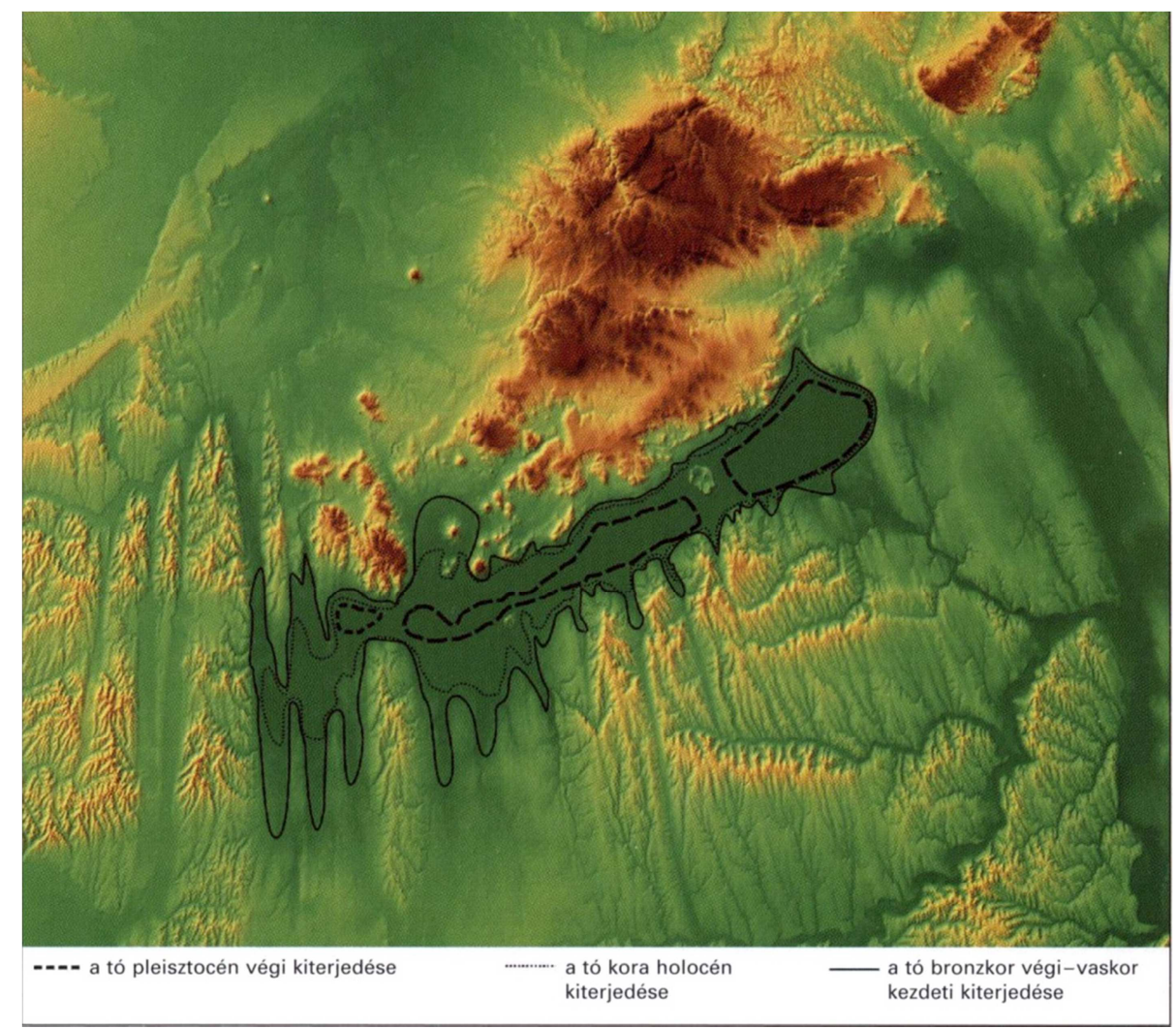

4. 2. ábra. A Balaton pleisztocén és kora holocén kori vízállása

(Sümegi et al. 2007, 245. kép)

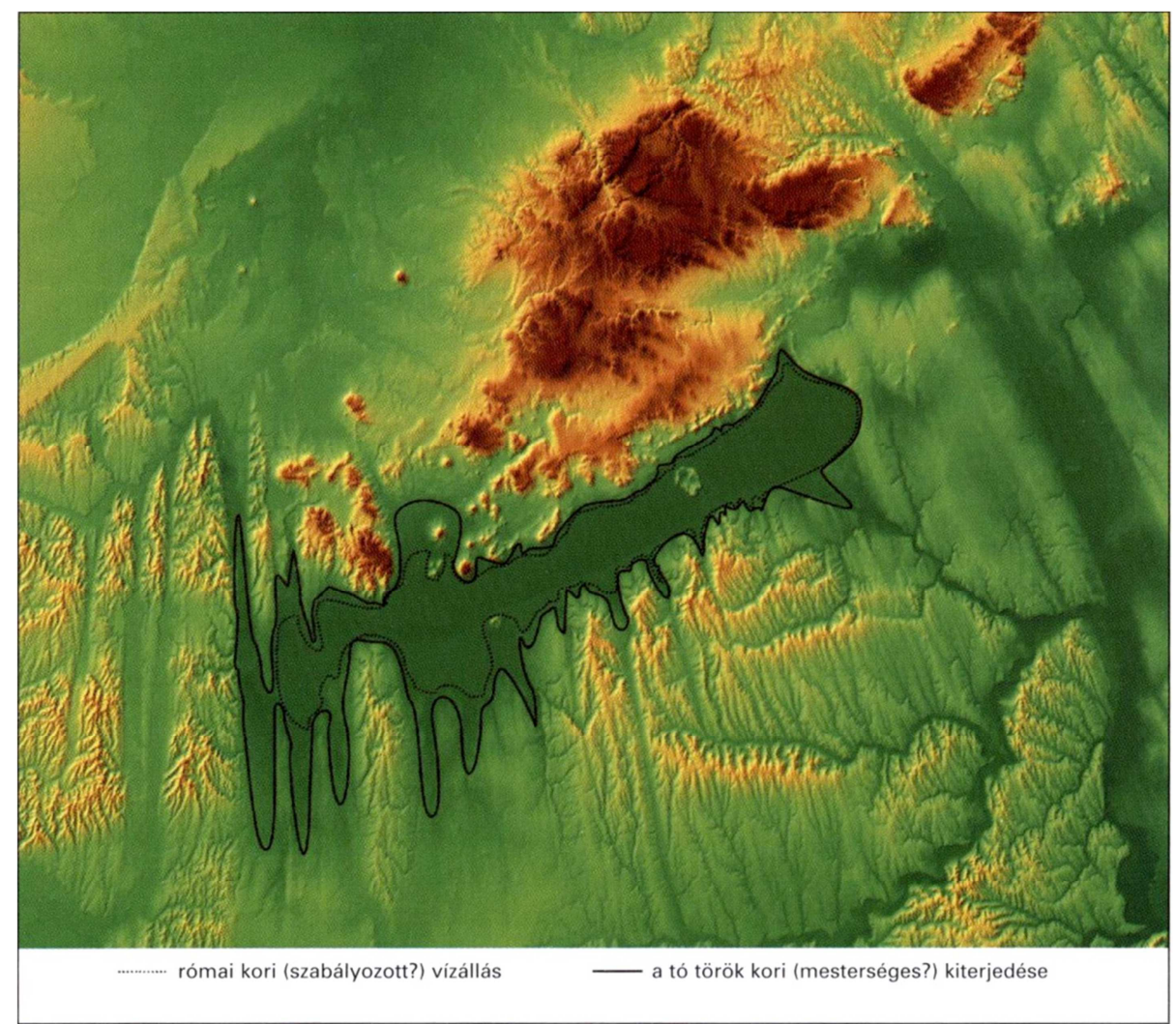

4.3. ábra. A Balaton római kori és középkori vízállása

(Sümegi et al. 2007, 246. kép) 
A következő, mindenképpen megemlítendő környezetrekonstrukciós és környezetrégészeti kutatás a Kis-Balaton térségében a keszthely-fenékpusztai késő római erőd és a környék lakosságának késő antik továbbélését vizsgáló programhoz kötődik. A Heinrich-Tamáska Orsolya által vezetett projekt keretében szintén Sümegi Pál és munkatársai végeztek kiterjedt vizsgálatokat a témában, mélyítettek több mintavételi fúrást is a késő római erőd közelében (Sümegi et al. 2011 541-572.) Részletes szedimentológiai, geokémiai, izotóp geokémiai, makrobotanikai, palinológiai, és malakológiai adatok alapján nagyjából teljes környezettörténeti rekonstrukció végeztek.

A területen a növénytermesztés és az állattenyésztés, a palinológiai adatok szerint a neolitikum végén, a rézkor elején kezdődött. Ennek közvetett eredményeként nagyfokú erózió és szervesanyag beáramlás kezdődött meg ebben az időszakban a Kis-Balaton öblözetébe, ami felgyorsította a meder feliszapolódását.

A medence történetében egy rendszeres ciklikusság fedezhető fel, amelynek során a mocsaras, lápi környezetet felváltja a tavi környezet, amelyet újból egy elmocsarasodott állapot követ. A középső bronzkortól a kora középkorig három ilyen ciklust azonosítottak a vizsgálat végzői.

Az első a kora és középső bronzkor idejére esik, a második a késő bronzkor és a kora vaskor időszakára, a harmadik pedig a késő vaskor és a római császárkor idejére.

Az elemzések alapján az is kimutatható volt, hogy a római korban jelentősen megváltozik a termesztett növények összetétele, számos új, főként a kertkultúrára jellemző faj jelenik meg a környéken.

Ugyan ehhez a kutatási témához kapcsolódnak Heinrich-Tamáska Orsolya legújabb eredményei, amelyekben Keszthely-Fenékpuszta környékének késő antik, népvándorlás kori történetét vizsgálja. Munkájában foglalkozik a Balaton római kori vízállásának tendenciáival a környezettörténeti adatokra alapozva, valamint elsősorban a pannoniai késő római belső erődhálózat és a pannoniai úthálózat kapcsán felmerülő kérdéseket fejtegeti a környezeti elemek figyelembe vételével (Heinrich-Tamáska 2014, 403-428). 
Végül meg kell említenem, hogy jómagam is több tanulmányban foglalkoztam szerzőtársaimmal közösen a Balaton régészeti korú vízállásváltozásaival, elsősorban a római kori vízállás és a sok vitát kiváltott római kori lecsapolás kérdéskörében (Fábián-Serlegi 2007, Pásztókai-SzőkeSerlegi 2013, 68-79; 273-284; Serlegi 2007, 297-317; Serlegi 2009, 501-514.). Ezen kívül több tanulmány is készült részvételemmel a késő rézkor időszakában a régészeti jelenségek alapján észlelhető éghajlati és vízállásváltozás, valamint ennek stabilizotóp geokémiai bizonyítékai kapcsán (Barna et al. 2009, 59-63; Demény et al. 2010, 82-94; Schöll-Barna et al 2012, 87-100; Serlegi et al. 2012, 139-150.). Ezekre a munkákra, minthogy a dolgozat következő fejezeteiben az ott közölt eredményeket is felhasználom, itt most részletesen nem térek ki.

Összefoglalva tehát elmondható, hogy a régészeti jelenségek geomorfológiai elhelyezkedése és tengerszint feletti magasságuk, valamint a Balaton vízszintváltozása közötti összefüggések tanulmányozása egyáltalán nem előzmények nélküli. Az M7 autópálya több korszakú lelőhelyeinek adatai újra nagy lendületet adhatnak a kérdéskör komplex vizsgálatainak. 


\section{Balatonkeresztúr-Réti-dűlő}

\subsection{A lelőhely leírása}

Balatonkeresztúr Réti-dűlő lelőhely feltárására 2003-2005 között az M7 autópálya tervezett nyomvonalának Somogy megyei szakaszán folyó megelőző régészeti feltárások, és építés közbeni leletmentések kapcsán került sor. A nagyberuházást megelőző feltárási munkálatokba a Somogy Megyei Múzeumok Igazgatóságának $^{1}$ felkérésére az MTA Régészeti Intézete ${ }^{2}$ is bekapcsolódott. Az esettanulmány lelőhelyén a 2003 és 2004 között folyó megelőző feltárást Fábián Szilvia $^{3}$ vezette, melynek munkálataiba a 2004. év során jómagam is bekapcsolódtam (Fábián 2004a, 2004b, 2005, 2007). A 2004 és 2005 évben a

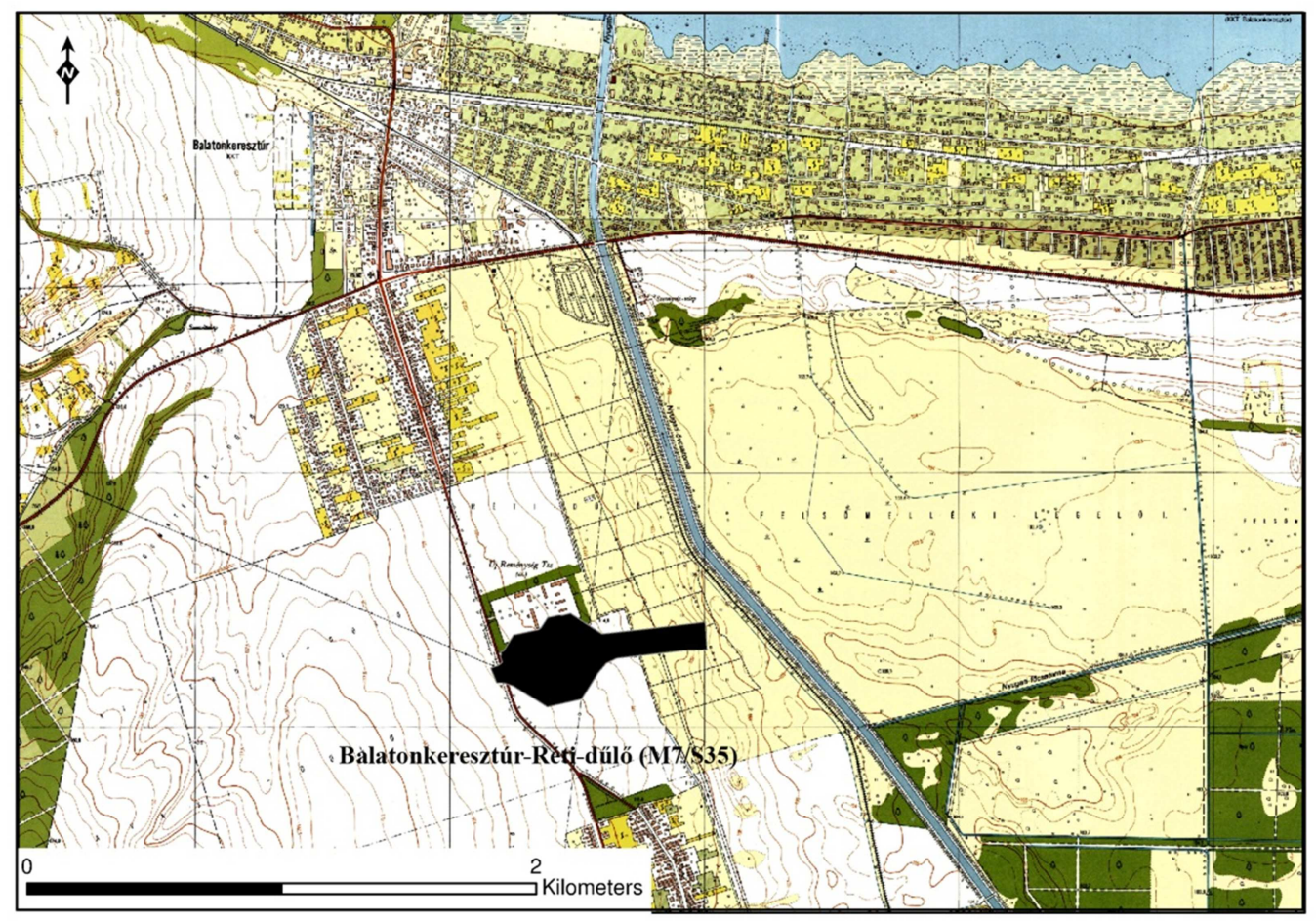

5.1. ábra. Balatonkeresztúr-Réti-dűlő (M7/S35) lelőhely elhelyezkedése

\footnotetext{
1 Jelenleg Rippl Rónai Múzeum, megyei hatókörű városi múzeum, Kaposvár.

2 Jelenleg MTA Bölcsészettudományi Kutatóközpont Régészeti Intézet

${ }^{3}$ A feltárást Fábián Szilvia az MTA RI munkatársaként vezette (jelenlegi munkahelye MNM NÖK). Az adatok átadásáért neki tartozom köszönettel.
} 
komplex pihenő által kijelölt terület építés közbeni feltárása zajlott (Fábián et al 2007).

A lelőhely a Balaton délnyugati partjához közel, Balatonkeresztúrtól 2 kmre déli irányba, a Balatonújlakra vezető 6707 műúttól keletre eső területen helyezkedett el (5.1. ábra). A tervezett M7 autópálya nyomvonala kelet-nyugati irányban 100 méter, a komplex pihenőhely részénél 350 méter széles sávban a Balaton partvonalával párhuzamosan szelte át a Marcali-löszhátat, amely fontos geomorfológiai megfigyelésekre nyújtott lehetőséget. A nyomvonal és a komplex pihenő által meghatározott, közel 900 méter hosszú és 100-350 méter széles terület, a középső rézkor elejétől kezdve, a késő bronzkor- kora vaskor, a római kor és a népvándorlás kor késői szakaszait leszámítva, egészen a középkorig szinte folyamatosan lakott volt (Fábián 2004a, 2004b, 2005, 2007; Fábián et al 2007; Fábián - Serlegi 2007, 2009).

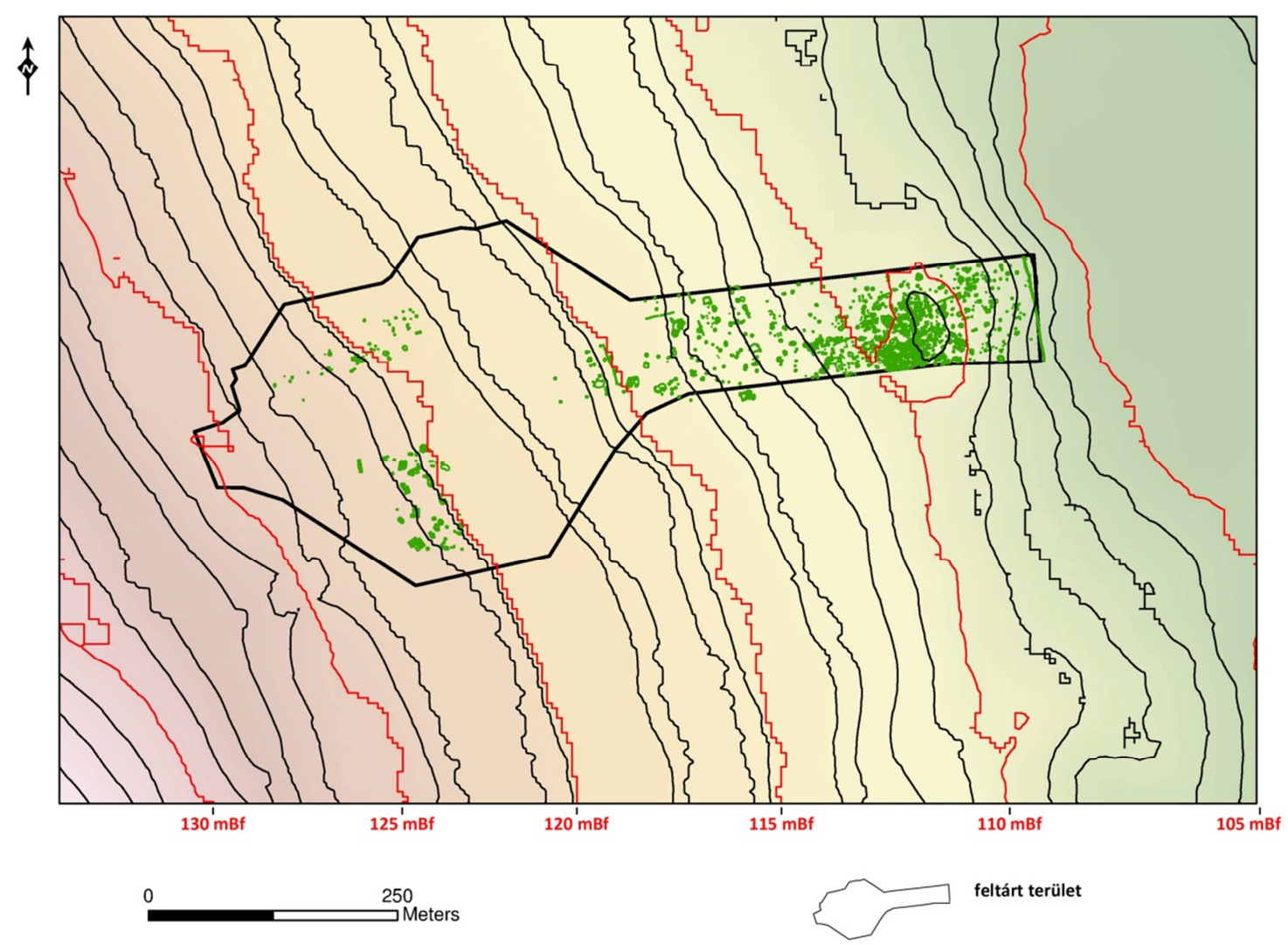

5.2. ábra. A balatonkeresztúri lelőhely régészeti fedettsége 
A terület nyugati része szántóföldi művelés alatt állt, míg keleti felét, amely egy meredekebbé váló lejtővel simult bele a Nagyberek mocsaras területébe legelőként hasznosították a feltárás időszakát megelőzően. A 2003-2005-ös év folyamán összesen közel $60.000 \mathrm{~m}^{2}$ területen több mint 3000 régészeti objektum került feltárásra (5.2. ábra). Hét régészeti korszak számos népességének emlékanyaga és megtelepedésének nyomai kerültek elő a területen (5.3. ábra). Az egybefüggő, nagy kiterjedésű felületeknek köszönhetően jól megfigyelhető volt a terület domborzati viszonyainak hatása az emberi megtelepedésre a különböző régészeti korszakokban, amelyek a későbbi elemzések során számos hasznos településtörténeti információval szolgáltak.

A lelőhelyen legkorábban a középső rézkori, Balaton-Lasinja kultúra népessége telepedett meg. Az elsősorban tároló és hulladék gödrökkel, gödörkomplexumokkal és egy alapárkos ház nyomaival jellemezhető, sűrűn lakott terület a lelőhely nyugati, műúthoz közel eső részén húzódott, de néhány objektuma szórványosan a meredekebb lejtő peremén is megtalálható volt (Fábián 2004a, 10; 2007, 28; Fábián et al 2007, 42-44.).

A késő rézkori badeni kultur-komplexum népessége az a középső rézkori objektumoktól keletebbre telepedett meg. Mind a korábbi bolerázi, mind a klasszikus és kései badeni időszak településmaradványai a Nagyberek mocsaras területéhez közel helyezkedtek el. A badeni település magja a Marcali-löszhát dombszerű kiemelkedésén helyezkedett el, de a bolerázi megtelepedés az attól kelet felé a Nagyberek partjához lefutó domboldalon is megtalálható volt. A dombtetőn koncentrálódó késő rézkori objektumok, a badeni kultúra nagy kiterjedésű, gödörkomplexumai, tároló és hulladék gödrei, tűzhelyek és egy boltozattal rendelkező kerámiaalapozású kemence mellett több, egész állatvázat tartalmazó „áldozati” gödör és néhány badeni temetkezés is napvilágra került. A mocsaras Nagyberek közvetlen közelében feltárt további nyolc É-D-i tájolású, zsugorított testhelyzetű, csontvázas temetkezés közül néhányat a melléklete feltételesen a késő rézkori horizonthoz köti (Fábián 2004a, 10; 2007, 27-28, VIII. tábla 1; Fábián-Serlegi 2007, 273-275; 2009, 203-205.).

A kora bronzkori Somogyvár-Vinkovci és kisapostagi kultúra népességének települési objektumai gödrök, épületnyomok és temetkezések ismét a felület nyugati részén koncentrálódtak, a lelőhely keleti felén csak 
elszórtan jelentkeztek megtelepedési nyomaik Feltehetően a kora bronzkor második feléhez köthető, a terület középső részére lévő 11 temetkezésből álló csontvázas rítusú sírcsoport, amelyben a halottak enyhén zsugorítva, oldalukra fordítva feküdtek, kezüket a sírba tétel során legtöbbször arcuk elé helyezték. A temetkezésekből néhány bronz ékszer is előkerült. Ezen a területen szórványosan a középső bronzkori mészbetétes kerámia kultúra időszakára keltezhető településnyomok is fellelhetők voltak (Fábián 2004a, 13-14.).

A balatonkeresztúri lelőhelyen a késő vaskor, La Tène C-D időszakában kelta népcsoport szállta meg a Marcali löszhát keleti lejtőjét. A felület nagy részén, egészen a Nagyberek széléig igen intenzív megtelepedés volt megfigyelhető. Ebben a korszakban a lejtős terület alsó részén tizenegy félig földbemélyített épület, öt kemence, számos verem és cölöplyuk került feltárásra. A keltezés szempontjából kiemelkedően fontos lelet volt az egyik ház járószintjén talált pénzérme, amelyet a Kr.e. 3. századi görög gyarmatvárosban, Neopolisban vertek. ${ }^{4}$ Az épületek közül egy másikban pedig nagy mennyiségű öntőtégelytöredék és fémsalak került elő utalva a területen működő műhelyek meglétére (Fábián 2004a, 13; 2007, 28.).

Szintén a lelőhely keleti részén, egy kisebb területen, egymáshoz közel, három, jellegzetes, hat cölöplyukból álló szerkezettel rendelkező, alig földbe mélyedő épület nyomai kerültek feltárásra. Ezekből, valamint néhány gödör, tároló verem és egy római tegulával bélelt kút leletanyaga alapján a Kr.u. 6. század elején, a környéken megtelepülő germán népcsoport, a langobardok megtelepedési nyomaira lehetett következtetni (Skriba 2006, 55-93.; FreedenVida 2007, 378-383.). A házak padlószintjéről, cölöplyukaiból és a gödrökből néhány jellegzetes bepecsételt mintával díszített edénytöredék, vaseszközök és tegulák kerültek elő (Fábián 2007, 29.).

A középkor időszakában az Árpád-kori megtelepedés nyomai a lelőhely szinte teljes hosszában és szélességében a Marcali-löszhát permének közelében is észlelhetőek voltak, bár igen elszórtan jelentkeztek. Legtöbb települési objektum, többek között egy félig földbemélyített épület, vermek és három kemence maradványa a felület középső részén, a dombtetőn összpontosult. A háztól kicsit

\footnotetext{
${ }^{4}$ Az érme meghatározását Dr. Redő Ferenc, régész végezte el. Az információért Neki tartozunk köszönettel.
} 
távolabb, nyugati irányban egy csoportban került elő öt nyújtott vázas temetkezés. A 10-11. századra keltezhető sírokban két felnőtt és három kisgyermek feküdt. Feltehetően ehhez a középkori megtelepedéshez kapcsolható még egy, a szokásostól eltérő módon, oldalára fekve eltemetett, nyújtott vázas, melléklet nélküli temetkezés is, amelyet a lelőhely északi szélén tártak fel az ásatók (Fábián 2004a, 14; 2007, 29.).

A középkor későbbi szakaszában hasonlóan a kelet-nyugati irányú lösz-plató és a lankás domboldal felső peremén sűrűn objektumkoncentráció volt tapasztalható, azonban az alacsonyabban fekvő, Nagyberekhez közeli helyeken már nem telepedtek meg. Ez a 13-15. századra keltezhető település a mai Balatonkeresztúrtól délnyugatra húzódó középkori Cholta nevű falu lehetett ${ }^{5}$ (Kiss 2006, 7-11). A plató legmagasabb részén nagyon intenzív települési nyomokat dokumentáltak, amelyek közvetlenül a jelenkori felszín alatt húzódtak. Egy többosztatú lakóház alapozásmaradványai olyan jó állapotban őrződtek meg, hogy ez alapján részben rekonstruálható az építmény egykori struktúrája. Az épületen belül egy többször megújított, kerámia-alapozású kemence és gazdag leletanyag is feltárásra került. Emellett több cölöpszerkezetes ház és félig földbe mélyített gazdasági épületek nyomai, vermek, kemencék, néhány faszerkezettel kibélelt kút és egy K-Ny-i irányú keskeny árok jelenti a középkori megtelepedést a lelőhelyen (Fábián 2004a, 14-15; 2007, 29.).

\begin{tabular}{|c|c|c|c|}
\hline $\begin{array}{c}\text { Régészeti korszak } \\
\text { és kultúra }\end{array}$ & Objektumok száma & Objektumok típusa & $\begin{array}{c}\text { Elhelyezkedésük } \\
\text { (tengerszint feletti } \\
\text { magasságuk) }\end{array}$ \\
\hline $\begin{array}{c}\text { középső rézkor, } \\
\text { Balaton-Lasinja } \\
\text { kultúra }\end{array}$ & 21 & $\begin{array}{c}\text { gödrök, gödör- } \\
\text { komplexumok, } \\
\text { cölöplyukak, kút, árok }\end{array}$ & $122-113 \mathrm{~m}$ \\
\hline $\begin{array}{c}\text { késő rézkor, Badeni } \\
\text { kultúra }\end{array}$ & 259 & $\begin{array}{c}\text { gödrök, kutak, } \\
\text { tűzhelyek, sírok, } \\
\text { cölöplyukak }\end{array}$ & $112-107 \mathrm{~m}$ \\
\hline $\begin{array}{c}\text { kora bronzkor, } \\
\text { Somogyvár-Vinkovci } \\
\text { kultúra }\end{array}$ & 97 & $\begin{array}{c}\text { gödrök, félig } \\
\text { földbemélyített } \\
\text { épületek, sírok }\end{array}$ & $117-110 \mathrm{~m}$ \\
\hline
\end{tabular}

\footnotetext{
${ }^{5}$ A lelőhely középkori leletanyagát Kiss Csaba dolgozta fel szakdolgozati téma keretében, valamint a telepölés nevét (Cholta) szintén ő azonosította okleveles adatok alapján.

${ }^{6}$ A régészeti kultúrához köthető objektumok száma.
} 


\begin{tabular}{|c|c|c|c|}
\hline $\begin{array}{c}\text { régészeti korszak és } \\
\text { kultúra }\end{array}$ & Objektumok száma & $\begin{array}{l}\text { Objektumok } \\
\text { típusa }\end{array}$ & $\begin{array}{l}\text { Elhelyezkedésük } \\
\text { (tengerszint feletti } \\
\text { magasságuk) }\end{array}$ \\
\hline $\begin{array}{l}\text { kora - középső } \\
\text { bronzkor, Kisapostagi } \\
\text { kultúra }\end{array}$ & 97 & $\begin{array}{l}\text { gödrök, félig } \\
\text { földbemélyített } \\
\text { épületek, sírok }\end{array}$ & $117-112 \mathrm{~m}$ \\
\hline $\begin{array}{l}\text { középső bronzkor, } \\
\text { Mészbetétes kerámia } \\
\text { kultúrája }\end{array}$ & 12 & gödrök & $117-110 \mathrm{~m}$ \\
\hline $\begin{array}{l}\text { késő vaskor, Kelta (La } \\
\text { Tène C-D) }\end{array}$ & 415 & $\begin{array}{c}\text { gödrök, félig } \\
\text { földbemélyített } \\
\text { épületek, kemencék, } \\
\text { kút, cölöplyukak }\end{array}$ & $117-110 \mathrm{~m}$ \\
\hline $\begin{array}{l}\text { népvándorláskor, } \\
\text { Langobard }\end{array}$ & 45 & $\begin{array}{l}\text { gödrök, félig } \\
\text { földbemélyített } \\
\text { épületek, kút, } \\
\text { cölöplyukak }\end{array}$ & $114-105 \mathrm{~m}$ \\
\hline középkor, Árpád-kor & 225 & $\begin{array}{c}\text { gödrök, félig } \\
\text { földbemélyített } \\
\text { épületek, kemencék, } \\
\text { kút, cölöplyukak }\end{array}$ & $110-105 \mathrm{~m}$ \\
\hline késő középkor & 1532 & $\begin{array}{l}\text { gödrök, félig földbe } \\
\text { mélyített épületek, } \\
\text { kemencék, kút, } \\
\text { cölöplyukak }\end{array}$ & $116-110 \mathrm{~m}$ \\
\hline
\end{tabular}

\section{3 ábra. A lelőhely régészeti korszakonkénti összesítő táblázata}

Az egybefüggő, nagy kiterjedésű felületeknek köszönhetően jól megfigyelhető volt a terület domborzati viszonyainak hatása az emberi megtelepedésre a különböző régészeti korszakokban. A terület legmagasabb pontja, a löszhát platója minden időszakban kedvelt volt, amit jól mutatnak a sűrűn egymásba ásott objektumok. Ettől a résztől keletre illetve nyugatra húzódó területeken az objektumsűrűség csökken, valamint jól követhetően megváltozik a terület különböző részeinek korszakonként megoszló kihasználtsága (Fábián-Serlegi 2007, 275-276.). 


\subsection{A lelőhely területének rétegtani vizsgálatai}

\subsubsection{A vizsgálathoz felhasznált adatok}

A Balatonkeresztúr-Réti-dűlő lelőhelyen megfigyelt régészeti jelenségek és a korszakonkénti településszerkezeti elmozdulások hátterében lévő indokok jobb

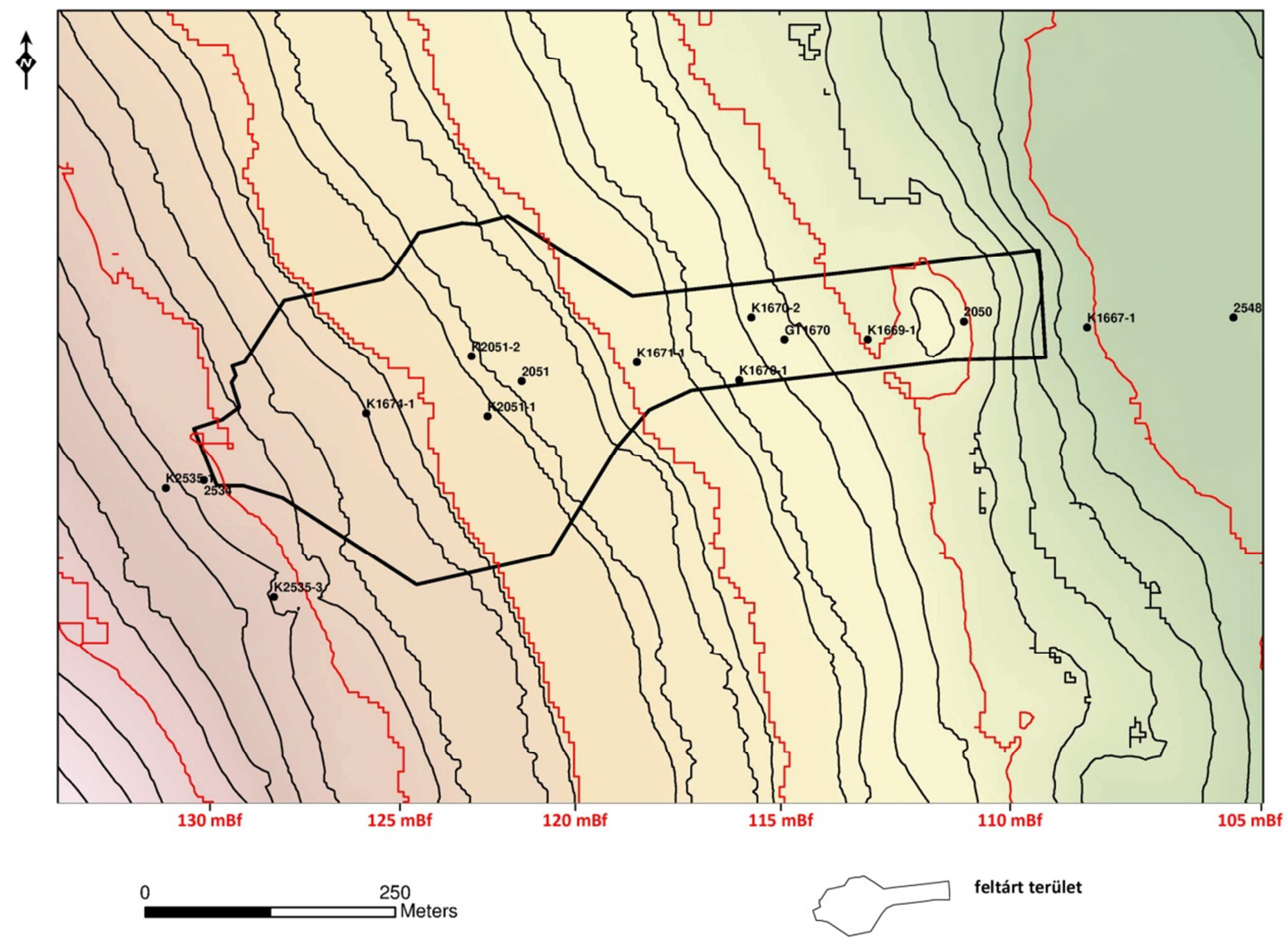

5.4. ábra. A balatonkeresztúri pihenőhely területén és környékén végzett talajmechanikai vizsgálatok helyszínei.

megértéséhez szükséges volt a terület földtani rétegzettségének és talajvízviszonyainak, a lehetőségekhez mért tisztázására. Sajnálatos módon, a lelőhely területén volt lehetőségünk a geológiai célú mintavételezésekre. Ezért az egyetlen elérhető, a terület földtani jellegére vonatkozó információs anyag az autópálya kivitelezését megelőző talajmechanikai vizsgálatok eredményei voltak. A vizsgálatokat az egykori Nemzeti Autópálya Rt. megbízásából a Fővárosi Mérnöki Tervező Részvénytársaság (FŐMTERV) Talajmechanikai Irodája végezte. 
Az adatokat a megrendelő engedélyével a FŐMTERV bocsátotta rendelkezésemre, tudományos kutatás céljaira7 .

A FŐMTERV-től kapott fúráskiértékelő adatlapok tartalmára támaszkodva megszerkesztettem a balatonkeresztúri lelőhely talajmechanikai adatok alapján rekonstruálható rétegtani és talajvízszint viszonyait. Az alábbi ábrák és következtetések ezeken az adatokon alapulnak, és ennek a modellezésnek az eredményeit mutatják be.

A balatonkeresztúri komplex pihenőhely területén és annak környékén összesen 17 fúrást mélyítettek (5.4. ábra). Az összes fúrás közül 10 volt alkalmas egy keresztszelvény kiszerkesztésére, megközelítőleg egy északkelet-délnyugati tengely mentén a lelőhely teljes hosszában (5.5. ábra).

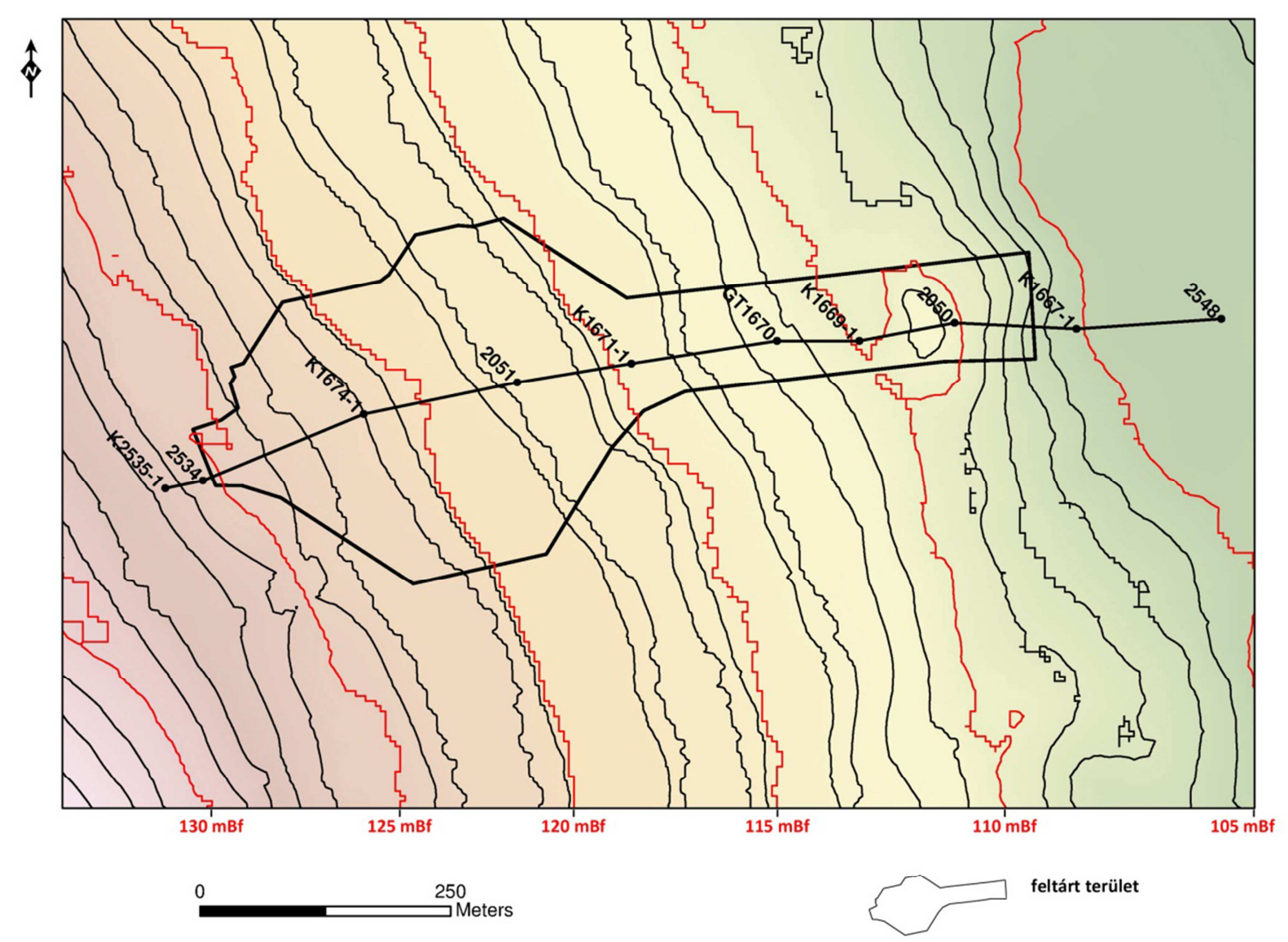

5.5. ábra. A talajmechanikai fúráspontok alapján kiszerkesztett talajmechanikai keresztszelvény vonala.

\footnotetext{
${ }^{7}$ Honti Imre irodavezető ez ügyben nyújtott segítségét ezúton is külön köszönöm.
} 
A fúrások eredeti célja az volt, hogy talajmechanikai eredményeket szolgáltasson a készülő autópálya létesítményeinek műszaki kivitelezéséhez. Ebből adódóan, a rendelkezésre álló adatok nem tették lehetővé a terület részletes geológiai kiértékelését, a dokumentált rétegek földtörténeti korú meghatározását. A rétegváltások mélységi adatai mellett elsősorban a rétegek teherbíró képességének vizsgálata érdekében a réteg kavics, homok, homokliszt és agyag összetevőinek arányát, sűrűségét és tömörödési arányát, illetve a fúrás időpontjába jelentkező talajvízszintet jegyezték fel. A réteghatárok mélységadatainak és a talajvízszintek rögzítése következtében azonban alkalmas volt a felszín alatti domborzati viszonyok és két, eltérő vízálláshoz tartozó talajvíztükör kiszerkesztésére.

A mintavételek mélysége eltérő volt, a legmélyebb fúrás 18 méter mély (K25351) míg a legsekélyebbek 5 méter mélyek $(2050,2051)$ voltak. A fúrások nagy részét 1992. februárjában (4 darab fúrás) és 2003. nyarán (5 darab fúrás) végezték, valamint egy fúrás 2001. novemberében készült. A VITUKI Központi Hidrológiai Adattárának adatai alapján, az 1992-es esztendő tél végi, februári vízállása átlagosnak mondható, a siófoki vízmérce nullpontja (103,41 mBf) feletti vízállás 1,02 méteres volt, ami 104,43 méteres vízszintet jelent ${ }^{8}$. Ez a vízállás még belül van napjaink szabályozási maximum értékén. Ugyan ennek az adatbázisnak az utóbbi két évtized egyik legszárazabb nyarára, 2003. augusztusra vonatkozó adatai alapján a vízszint a siófoki vízmérce nullpontja felett 0,35 méterrel volt, ami 103,76 méteres vízszintet jelent. Ez a vízállási érték 0,35 méterrel van az szabályozási értékek által engedett minimumszintnek ${ }^{9}$. Ez pedig természetes körülmények között is rendkívül alacsony vízállásnak felel meg.

A terület talajmechanikai rétegzettségének kiszerkesztéséhez használt 10 fúráspontból 8 a Marcali-hát keleti lejtőjére esett (K2532-1, 2534, K1674-1, 2051, K1671-1, GT1670, K1669-1, 2050), míg 2 már a Nagyberek területére (K-1667-1, 2548).

\footnotetext{
${ }^{8}$ (http://www.hydroinfo.hu/vituki/archivum/ba.htm)

${ }^{9}$ (http://www.kvvm.hu/balaton/lang hu/vizszintb.htm)
} 


\subsubsection{A szerkesztés során alkalmazott módszer}

A terület rétegzettségének általam elvégzett kiszerkesztésénél a kiindulási pont a talajmechanikai fúrások jegyzőkönyveinek értékelő adatlapja volt (1. melléklet). Minthogy a 2003. évi fúrásokat már a megelőző régészeti munkák megkezdése után végezték, így számos esetben a fúrás talppontja a már lehumuszolt felületre esett. Ezeken a részeken nem állt rendelkezésemre humuszvastagság, azonban a többi fúrás adatai alapján az egész területre nézve egy átlagos 0,6 méteres humuszréteggel számoltam. A mélyebb rétegekben az adatlapokon a vizsgálat jellegének megfelelően a homokos/homoklisztes és az agyagos/iszapos rétegeket különböztették meg elsősorban. Az azonos rétegek megfeleltethetőek voltak a különböző fúrásokban. Az adatlapokon feltűntetett rétegváltások relatív mélysége alapján könnyen átszámolható volt a rétegváltások abszolút tengerszint feletti magassága. A kivitelezőtől kapott koordinátajegyzék és a tengerszint feletti magasságok alapján előállítható volt a réteghatárok három téradattal rendelkező pontállománya. Ezt a pontállományt térinformatikai szoftverbe (ArcGIS - ArcMap 10.2) importálva, a pontok közötti interpolációval előállítottam a rétegváltások raszteres állományát, amelyre már rászerkeszthető volt a fúráspontok között a rétegváltások határvonala. A módszerből fakadóan a megközelítőleg egy kilométer hosszú keresztszelvényben elosztott tíz pont között az interpoláció csak egy elvi rétegtani határt tudott meghatározni, a keresztszelvény modelljében nem tudtam belekalkulálni a két pont között esetlegesen véget érő, majd újra induló illetve az átlapoló rétegeket.

A létrehozott három téradattal rendelkező réteghatár-vonalakat egy 3D megjelenítő programba (ArcGIS - ArcScene) importáltam, amelyben jól ábrázolhatóak voltak az egymás fölé rendeződő rétegek. A megfelelő nézőpont beállítása után az állományt a 3D megjelenítő programból kép formátumban exportáltam és később grafikai programmal vizualizáltam.

\subsubsection{Eredmények és következtetések}

A kiszerkesztett keresztszelvény alapján jól megfigyelhető (5.6. ábra), hogy a rétegzettség a domboldalon nagyobb mélységben is hasonló domborzati 
képet mutat, mint napjaink felszíne. Az átlagosan 0,6 méter vastagságú humusz alatt egy változó vastagságú, homokos-homoklisztes helyenként a 10 méteres vastagságot is elérő réteg húzódik. Ez alatt egy keskenyebb, ám helyenként a 3-6 méteres vastagságot is elérő agyagréteg következik. Az agyagréteg alatt egy második, az előzőnél vékonyabb homokos-homoklisztes réteg található. Ez alatt pedig újra egy agyagos réteg húzódik. Ennek a rétegnek a vastagságáról nem állnak rendelkezésre információk, a legmélyebb fúrások is ebben az agyagos

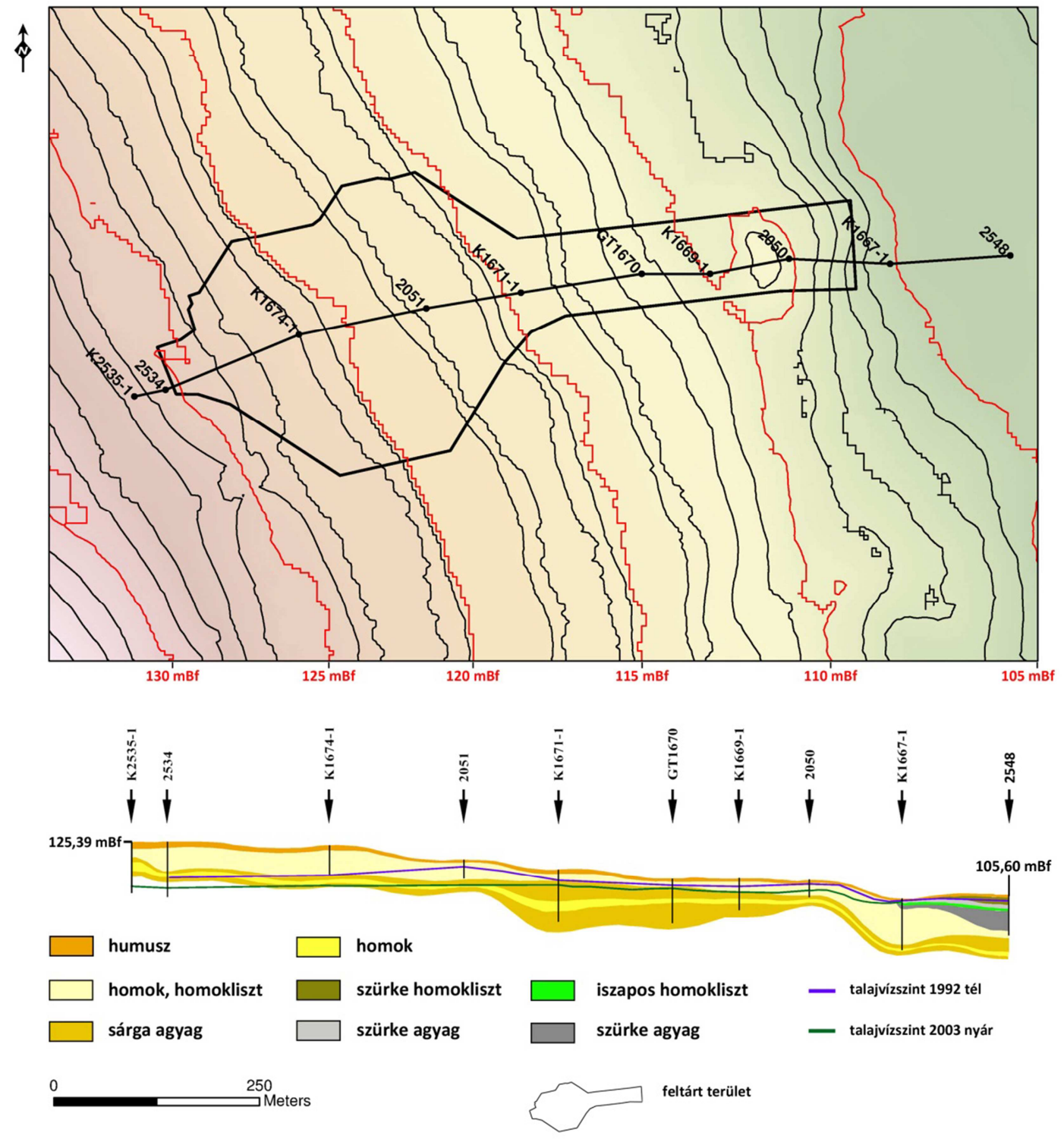

rétegben álltak meg.

\section{6. ábra. A balatonkeresztúri lelőhely kiszerkesztett talajmechanikai} keresztszelvénye a talajvízállásokkal. 
Általánosságban elmondható, hogy a felszín alatti rétegek megközelítőleg a maihoz hasonló domborzati viszonyokat követnek, kivételt képez ez alól a Marcali-hát és a Nagyberek határzónája, ahol az agyagos rétegek és a mélyebben lévő homokos réteg jóval meredekebb, mielőtt átmegy egy nagyjából vízszintes szakaszba. Ezen a részen a mai és a földtani kor reliefje közötti különbséget, a mélyebben fekvő felszín és a humuszréteg között, a humuszréteg alatti homokoshomoklisztes réteg legvastagabb része egyenlíti ki. A Nagyberek területén mélyített két fúrás (K-1667-1, 2548) azonosítható rétegei jól mutatják, hogy a korábbi, mélyebben húzódó homokos és agyagos rétegek fölé, a dombláb és a berek határán nem túl mélyen újabb, elsősorban tavi jellegű üledékek, szürke agyag és iszapos homokliszt deponálódtak.

A harmadik fejezetben, már érintettem, hogy a Balaton déli partja mentén a meridionális völgyek között húzódó hátak lejtőin megtalálható települések helyét első sorban a terület talajvízviszonyai határozták meg. A talajvíztükör mélységének ugyanis egyszerre kellett megfelelni annak a két feltételnek, hogy a Balaton évszakos vízállásváltozásai következtében emelkedő, illetve süllyedő talajvízszint ne befolyásolja a közösségek földbemélyített tárolóvermeit, ugyanakkor a települések vízellátásában nagy szerepet játszó kutakban az év minden szakaszában megfelelő mennyiségű víz legyen.

A fúráspontokban feljegyzett nyugalmi talajvízszintek adatai alapján a keresztszelvény modellezése kapcsán lehetőségem nyílott két eltérő, egy napjainkban is átlagosnak mondható, valamint rendkívül alacsony balatoni vízállása idején rögzített talajvíztükör modellezésére is (5.6. ábra).

A talajvíz szintje mind a két vízállás esetén a vizsgált lejtő magasabb térszínein, 126-127 méteres tengerszint feletti részeken húzódik a legmélyebben (5.6. ábra). Itt a fúrások adatai szerint eléri a 8-10 méteres mélységet is, a két időszak talajvízszintje között megközelítőleg másfél méter van (1992 tél - 8,5 méter; 2003 nyár - 9,8 méter). A modell alapján a két talajvíztükör nagyjából párhuzamos lefutást mutat, egyetlen jelentős kivétel a lejtő középső szakaszán 116-117 méteres felszíni magasságú részeknél rajzolódott ki, ahol a magas tavi vízállás esetében a talajvíz viszonylag a felszínhez közel, nem egészen 2 méter mélységben található, míg az alacsony vízállásnál egészen mélyen húzódik. Hozzá kell ehhez azonban tennünk, hogy a 2003. évi K1674-1 fúráspontban a 6 méter 
mélységig nem jelentkezett a talajvíz. Ez ugyan viszonylag mélyen húzódó talajvízszintet feltételez, de így a K2535-1 és K1671-1 fúráspontok közötti hosszú szakaszon a keresztszelvény vonalában csak interpolált adatok állnak rendelkezésre a 2003. évi talajvíztükör mélységét illetően. Az interpolált adatokat erősíti azonban két másik fúrás talajvízadata (K2051-1, K2051-2). Ezeket a fúrásokat szintén 2003 nyarán mélyítették, feltehetően kontrollvizsgálatok céljából. Bár nem esnek a keresztszelvény vonalába, azonban arra merőlegesen az 1992. évi 2051 fúrással vannak egyvonalban (5.3. ábra). A 2051 számú fúrásban a nyugalmi talajvízszint 1992 telén 116,3 méteren volt. A vonalába eső K2051-1 és K2051-2 fúrásokban 2003 nyarán a talajvíz szintje mind a két esetben 112,9 méteren, mintegy 3,5 méterrel mélyebben volt, ami erősíti az interpolált adatok valóság közeli értékét.

A lejtő középső szakaszától kezdődően, egészen a 110-111 méteres tengerszint feletti magasságban lévő nagyjából vízszintes platószerű részig a két talajvíztükör nagyjából párhuzamosan, a felszíntől viszonylag kis mélységben halad. A plató vízszintes részénél egészen a felszín közelében húzódik, majd a 110 méteres szint alatt, a Nagyberek széléig viszonylag meredekebben lejtő szakaszon megközelítőleg a felszíni domborzattal megegyező lejtéssel, nem túl nagy mélységben halad. Ezen a meredekebb részen a két vízálláshoz köthető talajvízszintek mélysége között nagyobb a különbség, mint a felső, alacsonyabb lejtésű domboldalon. A dombhát és a Nagyberek találkozásánál egészen felszín közeli értékeket mértek a fúrások időpontjában (1,1 méter a K1667-1 fúráspontban 2003 nyarán), valamint az 1992-es talajvízszint interpolációja során kapott szint is rendkívül magas értéket ad ezen a ponton. Ehhez mérten a Nagyberekben 1992 telén mért 1,15 méteres talajvízszint (2548 fúrás) furcsának tetszik, azonban nagy valószínűséggel e-mögött az érték mögött a Nagyberek mesterséges csatornázottságát és a folyamatos, a Balatonba történő vízátemelés kell sejtenünk.

Összefoglalásként elmondható, hogy a Marcali-hát keleti lejtőjén, a mélyebben fekvő, idősebb geológiai rétegek váltakozó agyagos és homokoshomoklisztes üledékekből állnak. A felszín alatti rétegek lejtési viszonyai nagyjából megegyeznek a mai felszín reliefjével. A korábbi geológiai rétegsorok mélyebben fekvő szakaszai folytatódnak a Nagyberek alatt is. Ezen a részen a 
korábbi rétegekre eltérő összetételű feltehetően tavi eredetű üledékek rakódtak a lejtő legaljánál, a mai berek területén. A Balaton fejlődéstörténetét és vízborításának kialakulását tárgyaló fejezetben leírtak alapján ezek az agyagos és iszapos üledékek már a holocén folyamán keletkezhettek.

A talajmechanikai vizsgálatok során tapasztalt talajvízviszonyok alapján modellezett talajvíztükrökről elmondható, hogy a domboldal felsőbb rétegeiben a vízállástól függetlenül mélyen húzódik, és a lejtőn keleti irányba haladva fokozatosan egyre inkább a felszín közelében található. A 110-111 méteres tengerszint feletti magasságban található nagyjából vízszintes platónál észlelhető legmagasabban a Nagyberekig tartó meredekebb szakaszon pedig követi a felszín lejtését. A Nagyberek és a dombláb találkozásánál egész csekély mélységű. A modell értelmezéséhez hozzá kell azonban tennünk, hogy a megközelítőleg egy kilométer hosszú keresztszelvényben a talajvíz adatok megoszlanak a szerkesztéshez használt 10 fúráspont között. Ebből adódóan a két érték közötti interpolált szakasz hossza is megnövekszik. A már említett kivételtől eltekintve a két modellezett talajvíztükör meglehetős párhuzamosságot mutat, ami erősíti a modell használhatóságát, azonban a két ismert pont közötti szakaszon a talajvízszint abszolút magassági értékeinek megállapítására nem alkalmas. Természetesen ez a megállapítás érvényes a geológiai rétegsorok határának két pont közötti abszolút magassági értékeire is, ebben az esetben a felhasználható nagyobb számú pont következtében valamivel jobb a modell felbontása.

A talajvíztükör és a fúrásokban észlelt vízszintek esetében meg kell még említenünk, hogy a lelőhely keleti végén, a Nagyberek nyugati szélén fut napjainkban a Nyugati-övcsatorna, amely a Nagyberekbe torkolló vízfolyások vizét hivatott összegyűjteni. A rendelkezésre álló adatok alapján nehéz megítélni a csatorna modern kori, mesterséges medrében lévő vízmennyiség talajvízre gyakorolt visszaduzzasztó hatását. Feltételezhető, hogy a természetes állapotban az övcsatorna hatása nélkül alacsonyabb talajvízszinttel számolhatunk a dombhát lejtőjén, azonban ennek mértékét a jelen pillanatban rendelkezésemre álló adatok alapján nem lehet megbecsülni 10 .

10 Köszönettel tartozom Dr. Sümegi Pálnak, hogy a Nyugati-övcsatorna visszaduzzasztó hatására felhívta figyelmemet a beszélgetéseink során. 


\subsection{A régészeti korszakok megtelepedési zónái a lelőhelyen}

A balatonkeresztúri lelőhely modellezett talajvízviszonyainak ismeretében meg kell vizsgálnunk a lelőhelyen megtalálható korszakok megtelepedési zónáit, települési súlypontjait és az esetleges korszakra jellemző sajátosságokat.

\subsubsection{A középső rézkor - Balaton-Lasinja kultúra időszaka (4300-4000 cal BC)}
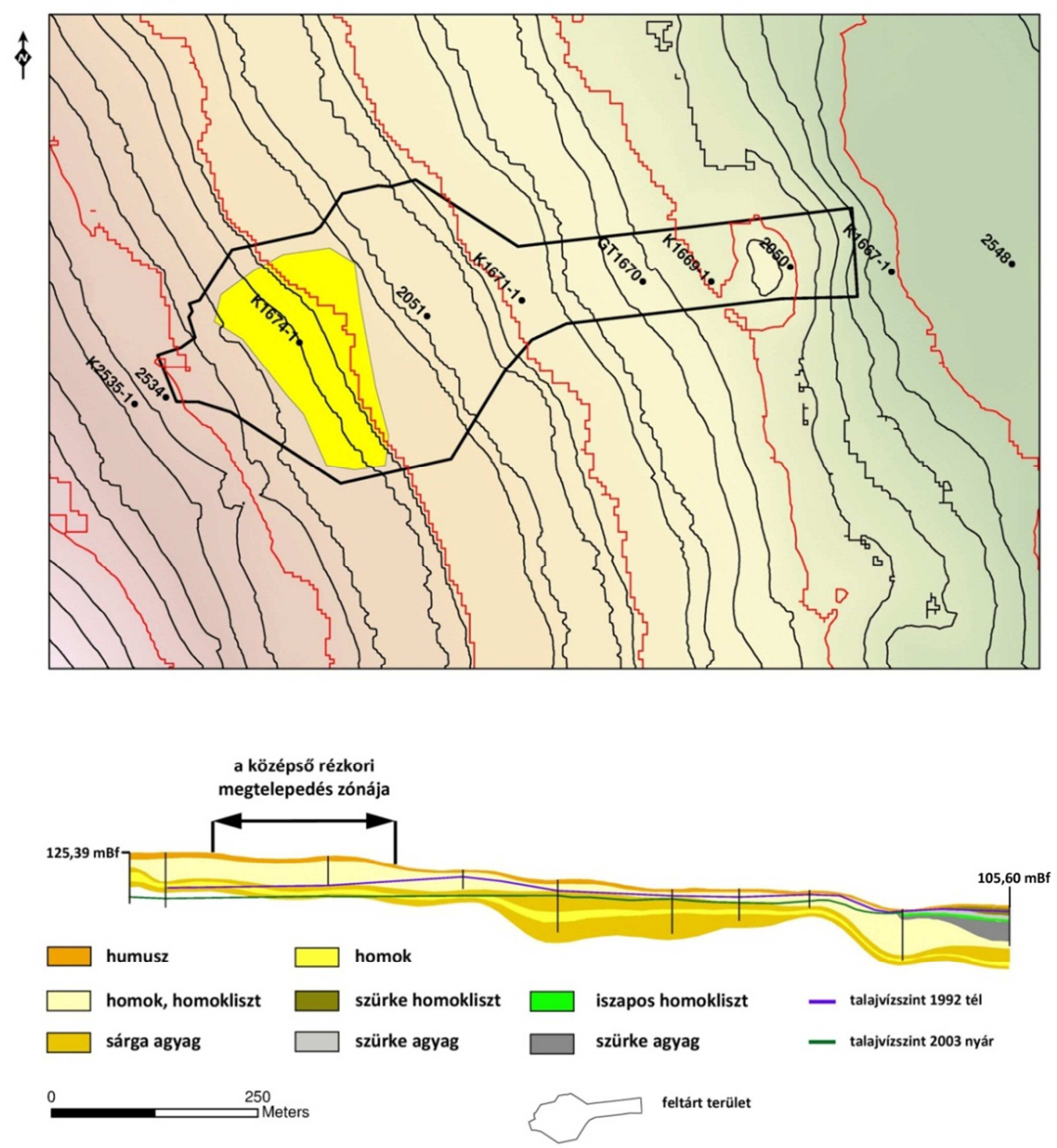

5.7. ábra. A középső rézkori megtelepülés zónája a balatonkeresztúri lelőhelyen. 
A középső rézkori megtelepedési zóna jól látható módon a Marcali-hát keleti lejtőjének magasabb, 120 méter körüli térszínein található (5.7. ábra). A vizsgált területnek ez a szakasza, ahol a talajvíztükör mind az alacsonyabb, mind a magasabb vízállás esetén egyaránt nagymélységben húzódik. A talajvízviszonyok meghatározó szerepéről mondottak alapján ebben az időszakban rendkívül magas balatoni vízállásviszonyokat rekonstruálhatnánk. A középső rézkori megtelepedés súlyponti zónáján kívül, azonban a feltárt felületen néhány esetben előkerültek a korszak jellegzetes anyagával keltezhető objektumok ${ }^{11}$. A B-1589 kútjellegű beásás a domboldal alsóbb szakaszán került elő. A gödör megtalálási szintje, a humusz eltávolítását követően 108,85 méteren volt bontható, a legalját nem tudták elérni a folyamatosan, nagy erővel beáramló talajvíz miatt. A kút bontásának idején 2004 áprilisában a Balaton vízállása 104,1 méter körüli volt 12 .

Ebből következően viszont feltételezhetjük, hogy a középső rézkor időszakában egy alacsonyabb talajvízszinttel és egy alacsonyabb balatoni vízállással számolhatunk. Természetesen ebben az esetben is figyelembe kell vennünk a Nyugati-övcsatorna esetleges visszaduzzasztó hatását.

\subsubsection{A késő rézkor -Boleráz-Badeni kultúra időszaka (3600-2900 cal BC)}

A késő rézkori megtelepedés zónája a lejtő alsó szakaszán és a 110-111 méteres magasságban lévő vízszintes platón koncentrálódik. A 107 méteres szint alatt nem találhatóak a korszakhoz köthető objektumok (5.8. ábra). A lelőhely régészeti korszakai közül a késő rézkori leletanyag feldolgozása van a legelőrehaladottabb állapotban. Fábián Szilvia a korszakra vonatkozó kerámia tipológia segítségével három megtelepedési fázist tudott elkülöníteni a késő rézkor időszakán belül. A három fázison belül a település szerkezetében történt változások is megfigyelhetőek voltak. Ezt a három, régészeti adatok alapján jól elkülöníthető, időben egymást követő fázist a későbbi radiokarbonkeltezés is megerősítette (Fábián-Serlegi 2009, 206-215; Serlegi et al. 2012, 140-142.).

\footnotetext{
11 Fábián Szilvia szíves szóbeli közlése alapján

12 (http://www.hydroinfo.hu/vituki/archivum/ba2004.htm)
} 
A legkorábbi, bolerázi időszakhoz köthető megtelepedésre egy viszonylag szórt település szerkezet jellemző a késő rézkori megtelepedés zónáján belül. Ennek a
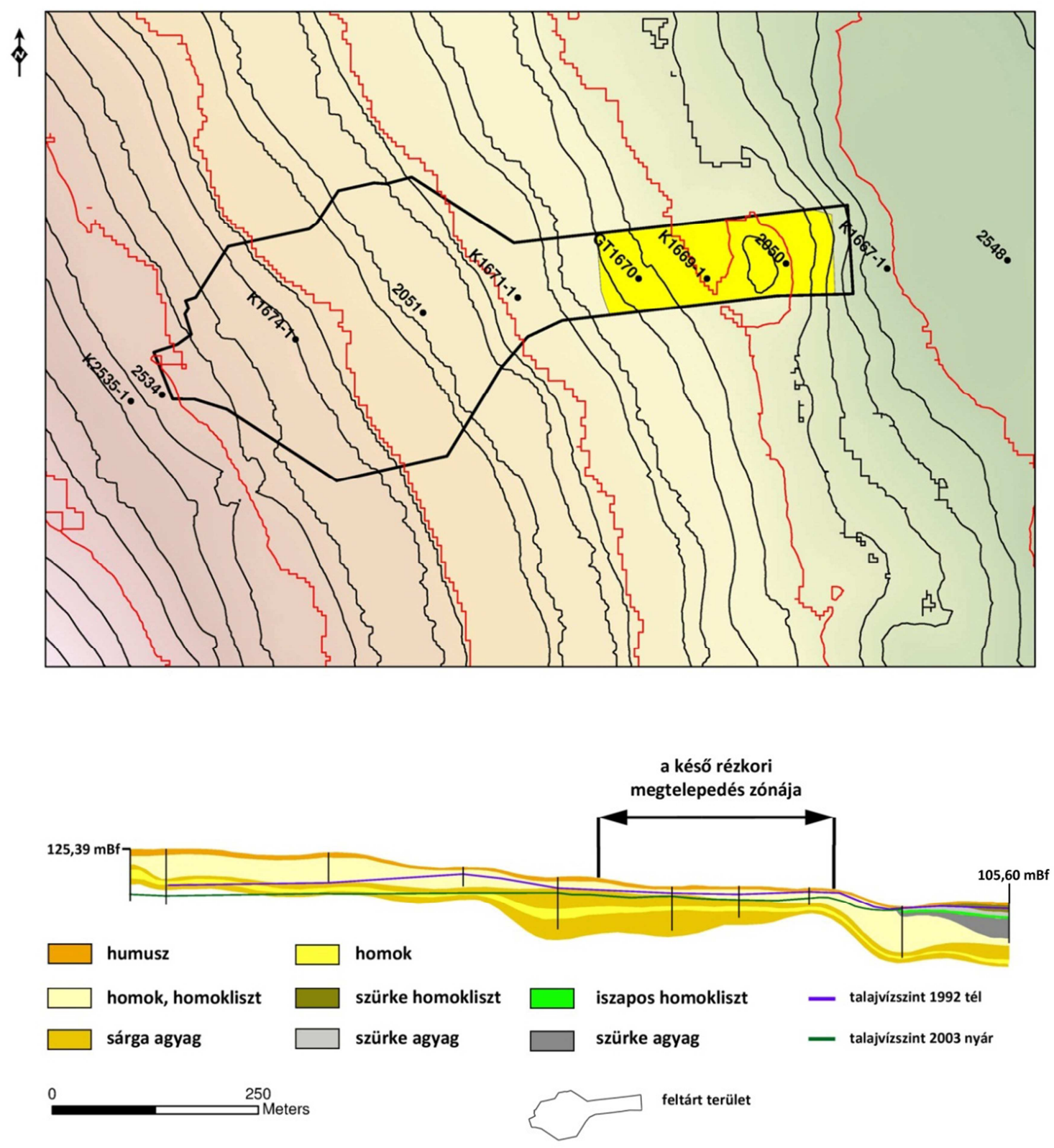

5.8. ábra. A késő rézkori megtelepülés zónája a balatonkeresztúri lelőhelyen.

fázisnak az objektumai találhatóak a legalacsonyabb tengerszint feletti magasságon a késő rézkor időszakán belül. A korai klasszikus időszakban egy településkoncentráció megindulása figyelhető meg, a vízszintes platón megsűrűsödtek az objektumok. A késő klasszikus badeni időszakra ez a 
településkoncentráció folytatódott, a telep kiterjedése kisebb lett, elsősorban a platóra összpontosult (5.9. ábra).

A településszerkezeti megfigyelések alapján egy fokozatosan csapadékosabbá váló időszak következtében emelkedő balatoni és talajvízszintre lehetett következtetni, ami a megtelepedésre alkalmas területek szűkülését
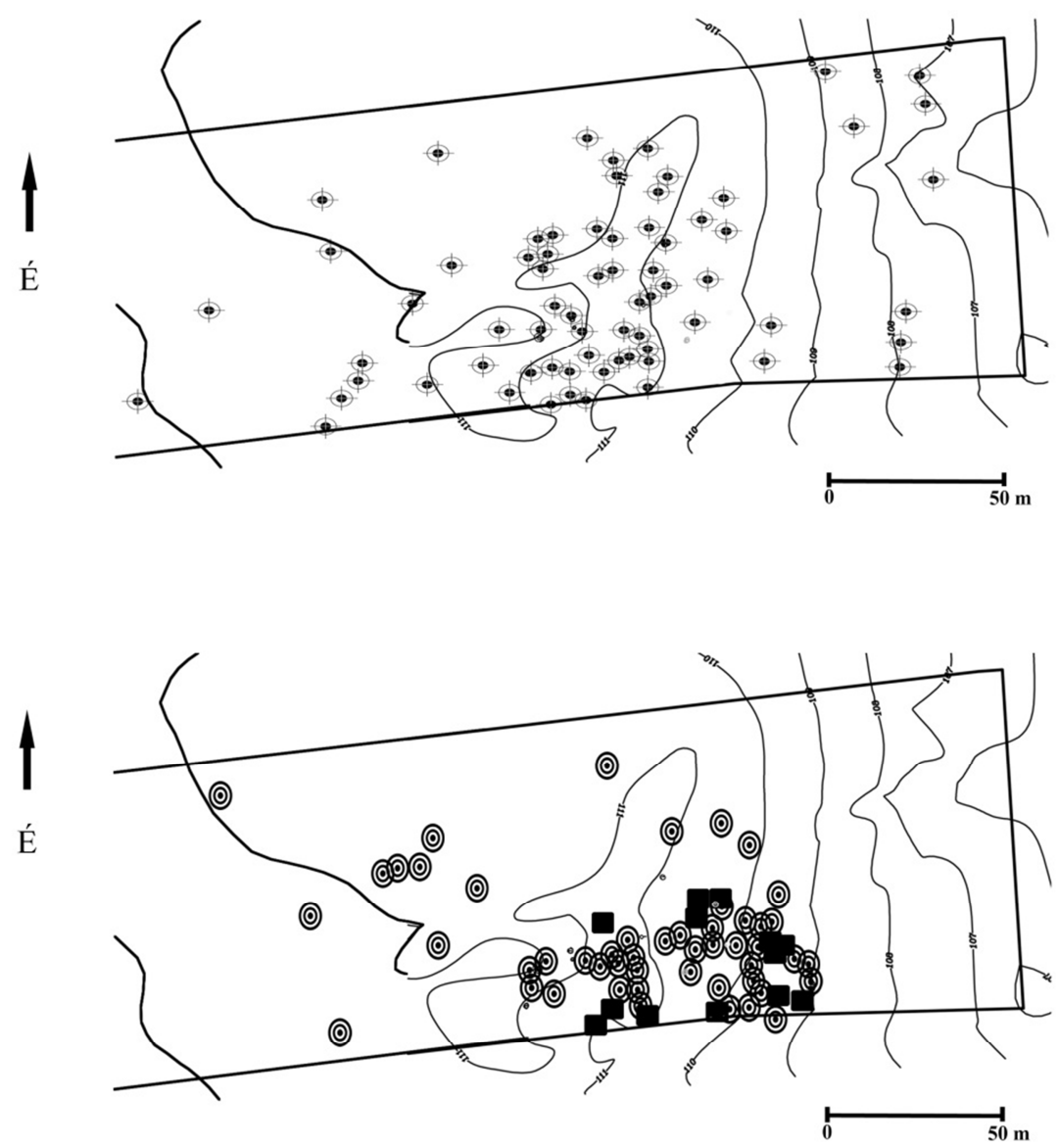

- bolerázi időszak

๑ korai klasszikus baden - késő klasszikus baden

5.9. ábra. A késő rézkori időszak fázisainak elhelyezkedése a balatonkeresztúri lelőhelyen. (Serlegi et al. 2012, 1. ábra)

eredményezte, ennek következtében zsugorodott a település súlypontja. Ezt a feltételezést erősítette a három időszak állatcsont anyagának archaeozoológiai elemzése is. A vizsgálatok azt mutatták, hogy a bolerázi időszak túlnyomóan szárazságtűrő fajtáinak dominanciája a klasszikus badeni időszakban megszűnik, a súlypont az állatállományban először a szarvasmarha, majd a nedves 
körülmények között megfelelő módon tartható sertéstartás irányába tolódott el (Fábián-Serlegi 2009, 215-218; Serlegi et al. 2012, 142-144.).

A következtetések igazolására az három időszak szignifikáns objektumaiból származó kagylókon (Unio pictorum) stabilizotóp geokémiai vizsgálatokat $\left(\delta^{18} 0\right)$ végeztünk a korszak éghajlati jellegének meghatározásához (Barna 2009, 59-63; Demény et al. 2010, 87-88; Schöll-Barna et al. 2012, 87-100; Serlegi et al. 2012, 144-146.). A stabilizotóp geokémiai elemzések nem igazolták mindenben a régészeti adatokból levonható következtetéseket, illetve tovább árnyalták a képet.

Az eredmények alapján a bolerázi időszakban viszonylag kiegyensúlyozott éghajlati körülmények uralkodtak. A bolerázi időszak végén, a korai klasszikus badeni időszak elején lévő átmeneti fázisban az stabilizotópok tanúsága szerint az éghajlat csapadékossá és szélsőségesen ingadozóvá vált, majd a korai badeni időszak kicsit csapadékosabb fázisa után az éghajlat a késő klasszikus időszak végére a bolerázi időszak éghajlati viszonyaihoz hasonlóan alakult.

Jól látható, hogy az emberi közösségek reakciói nincsenek mindig szinkronban a környezeti és éghajlati változásokkal, a megváltozó környezeti feltételek következtében meginduló társadalmi, gazdasági folyamatok a klimatikus visszarendeződés esetén nem feltétlenül térnek vissza a változások kezdete előtti állapotba.

\subsubsection{A kora és középső bronzkor -Somogyvár-Vinkovci, Kisapostagi és Mészbetétes Kerámia kultúrák időszaka $(2500 / 2400$ - 1600/1500 cal BC)}

A kora és középső bronzkori kultúrák megtelepedési zónája a balatonkeresztúri lelőhelyen a domboldal középső szakaszán van (5.10. ábra). Ez az az időszak, leszámítva a középső rézkor idejét, amikor a település objektumai nem észlelehetőek a vízszintes platótól keletre eső meredekebb domboldalon. Sajnálatos módon, a korszak lelőhelyen tapasztalt jelenségeinek részletesebb elemzését sem a leletanyag feldolgozottsági állapota, sem a viszonylag kisszámú objektum nem teszi lehetővé. Hozzátehetjük azonban, hogy a megelőző feltárásokat követő építés közbeni régészeti munkálatok során a lelőhelynek azon 
a részén, ahová a középső rézkori megtelepedési zóna súlypontja esik további két kora bronzkori gödör került elő (Honti et al. 2007, 42-44). Ezen felül a megelőző feltárások során külön lelőhelyként kezelt, a 6707-es műút túloldalán 130 méteres tengerszint feletti részen húzódó Balatonkeresztúr-Kiserdei-dűlő (M7/S36)
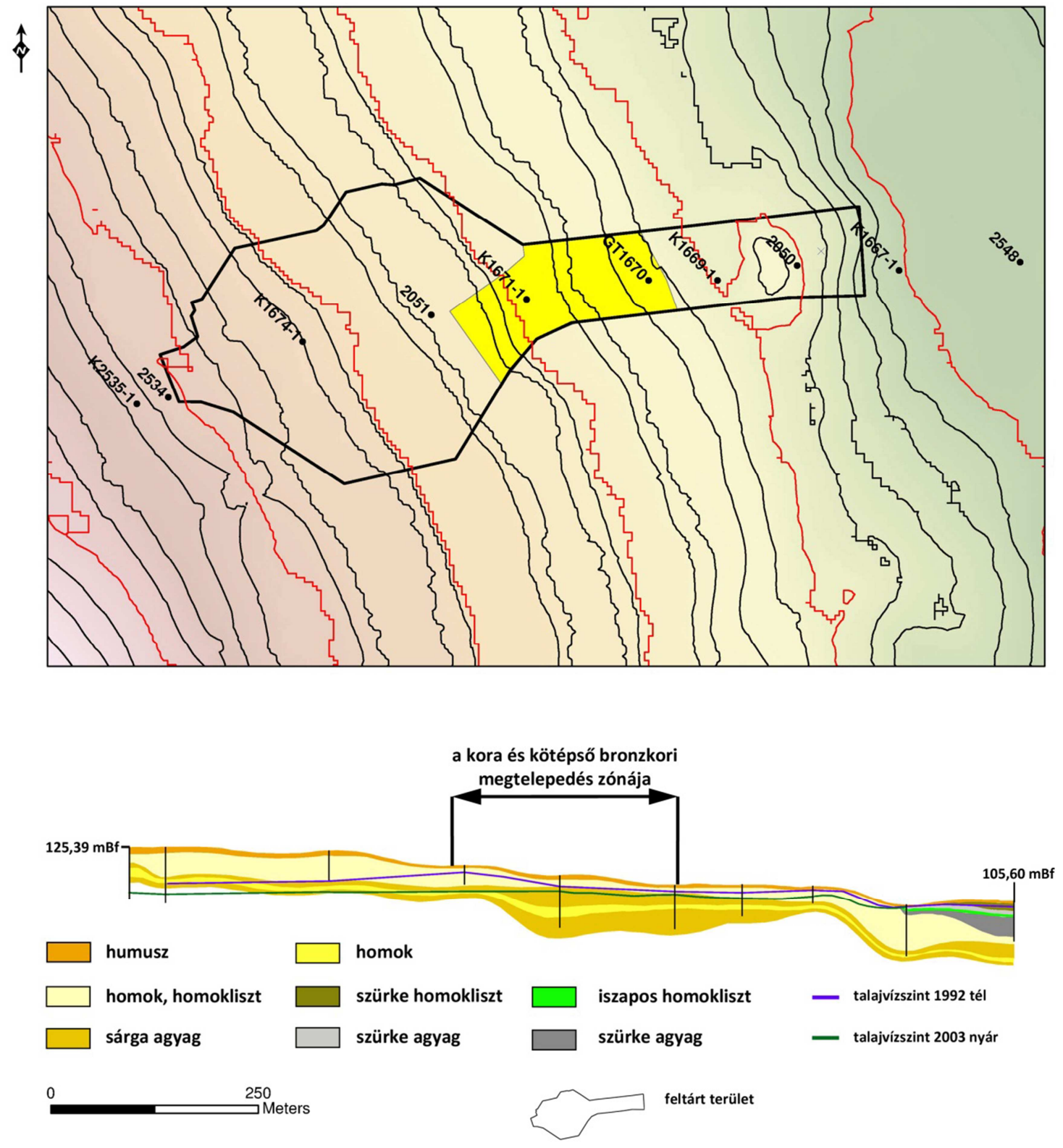

5.10. ábra. A kora és középső bronzkori megtelepedés zónája a balatonkeresztúri lelőhelyen. 
lelőhelyen kevés objektumában de szintén megtaláltuk a kora bronzkori Somogyvár-Vinkovci és Kisapostagi kultúrák telepjelenségeit (Honti et al. 2004, 9-10.). A jelenlegi adatok alapján nem dönthető el, hogy az előkerült objektumok ugyan ahhoz a településhez tartoznak-e, de minden esetre jól jelzi, hogy a kora bronzkori népesség a domboldalak magasabb régióiban alakította ki településeit, ahol a talajvízszint már minimum 9-10 méteres mélységben van. Ilyen mélység mellett nehéz elképzelni, hogy bármilyen mértékű tavi vízszintemelkedés következtében a talajvíz befolyással lett volna a települési objektumokra és a megtelepedés helyének kiválasztása szoros összefüggésben lenne a talajvíz, valamint a tó vízállásával.

\subsubsection{A késő vaskor - La Téne C-D kultúra időszaka (Kr.e 4-1. század)}

A késő vaskori megtelepedés zónája a lelőhelyen a domboldal teljes alsó szakaszán megfigyelhető volt (5.11. ábra). Ebből az időszakból ismerjük az első olyan településobjektumokat, amelyeket szinte egészen a Nagyberek széléig tartó lejtőszakaszon alakítottak ki. Jelen pillanatban a korszak leletanyagáról nem rendelkezünk részletes régészeti feldolgozással. A késő vaskori megtelepedés Balatonkeresztúr-Réti-dűlő lelőhelyen tapasztalt településszerkezeti adatai, valamint a korszak általános éghajlat kutatási eredményei alapján megkockáztathatunk néhány következtetést. A viszonylag alacsony, 105 méteres tengerszint feletti részen észlelt objektumok alapján feltételezhetjük, hogy ebben az időszakban a tó vízállása rendkívül alacsony volt. Ezt alátámasztják a dendrokronológiai vizsgálatok eredményei is, amelyek erre az időszakra rendkívül száraz és meleg időszakot valószínűsítenek a fák éves növekedési mutatói alapján. Jól mutatja ezeket az éghajlati tényezőket a „pannoniai tölgykronológia”, a Kr.e. 170-től a Kr.u. 90-ig tartó, egybefüggő szakasza. Az adatsort magyarországi régészeti lelőhelyek famintáiból Grynaeus András állította össze (Grynaeus 2004, 93-94.). Ezeknek az adatoknak a figyelembevételével megalapozottnak tûnik, hogy a lelőhelyen tapasztalt késő vaskori megtelepedés tengerszint feletti magasságai egy viszonylag alacsony vízállást sejtetnek az időszakban. 

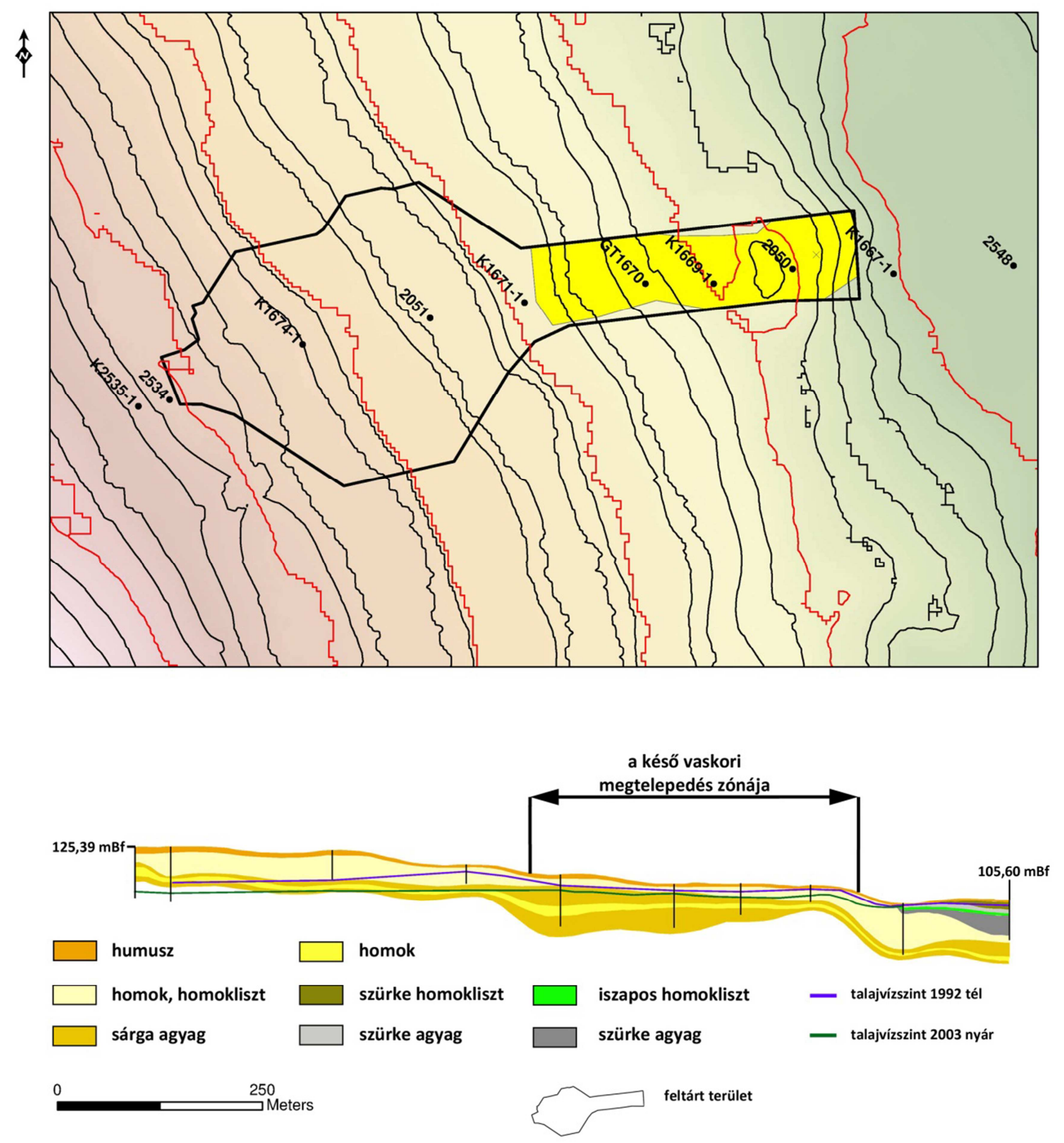

5.11. ábra. A késő vaskori megtelepedés zónája a balatonkeresztúri lelőhelyen.

\subsubsection{A népvándorlás kor (Langobard) időszaka}

(Kr.u. 6. század)

A népvándorlás kori megtelepedési zóna a domboldal legalsó, Nagyberekhez közeli részén volt megfigyelhető a lelőhelyen (5.12. ábra). Ez az időszak már a római kori első jelentősebb antropogén beavatkozás időpontja utánra esik. Ebből a szempontból érdekes, hogy a lejtő legalsó régiójában, a talajvízhatással leginkább érintett területen kerültek elő a korszakhoz köthető településnyomok. Ez lényegében teljesen ellentmond annak az általánosan 
elterjedt nézetnek, hogy Pannonia provincia római felhagyása után a római kori szabályozási létesítmények felhagyása után a karbantartás hiánya miatt a Balaton
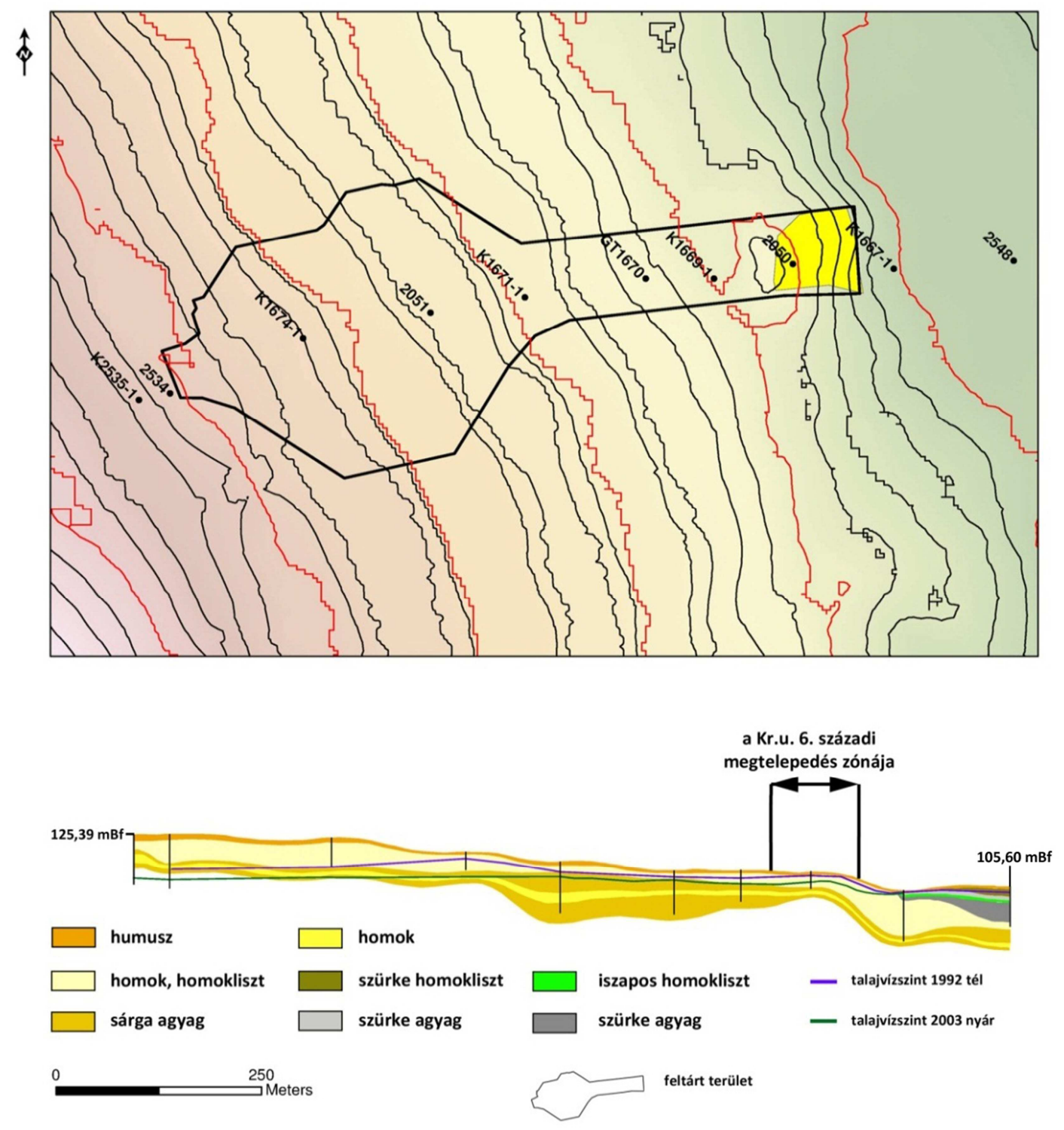

5.12. ábra. A népvándorlás kori (Kr.u. 6. század) megtelepedés zónája a balatonkeresztúri lelőhelyen.

siófoki kifolyása - legalábbis részlegesen - elzáródott és ezért a tó vízállása megemelkedett (Bendefy 1968, 258.). A Zamárdi-Kútvölgyi-dűlőben feltárt népvándorlás kori kútban észlelt vasas kiválás által bizonyítható 103,3-104,3 méteres tengerszint feletti nyugalmi vízszint a lelőhely leletanyagának jelenlegi feldolgozottsági szintjén nem hozható teljesen szinkronba a balatonkeresztúron tapasztalt jelenségekkel (Sümegi et al. 2007, 252.). A zamárdi lelőhely 
népvándorlás kori telepének összetett kronológiai viszonyai mellett nem dönthető el a kút pontos kora. Ezen kívül nem rendelkezünk pontos információkkal a lelőhelyen uralkodó talajvízviszonyokról sem. A két lelőhely adatainak összehangolása egy későbbi kutatás feladata lehet.

\subsubsection{Az Árpád-kor időszaka}

(Kr.u. 10-11. század)

Az Árpád-korra keltezhető település megtelepedési zónája a domboldal középső szakaszán figyelhető meg. A keleti végén a vízszintes platóig tart, objektumai nem fordulnak elő 110 méter alatti szinteken. A jellegzetes Árpádkori település elszórt objektumai jól megfigyelhetőek az egész területen (5.13. ábra). A korszak megtelepedési zónája megközelítőleg ugyan azon a területen helyezkedik el, ahol a korábbi, a tó vízállásába történő emberi beavatkozást megelőző időszakok régészeti kultúráinak nagytöbbsége. A természetestől eltérő állapotok miatt azonban csak annyi valószínűsíthető, hogy ebben az időszakban sem lehetett a Balaton vízállása lényegesen eltérő a korábbi időszakokéhoz képest.

\subsubsection{A középkor időszaka}

(Kr.u. 13-15. század)

A középkori Cholta falu megtelepedési zónája lényegében ugyan azt a területet foglalja el, mint az Árpád-kori település. Ebben a későbbi időszakban viszont egy jóval sűrűbb megtelepedés és objektumok koncentráció jellemzi a területet (5.14. ábra). A települési objektumok ebben a korszakban sem húzódnak a 110 méteres szint alá, ami az Árpád-korihoz hasonló talajvízviszonyokat feltételez.

A település pusztulására nézve konkrét adataink nincsenek, de más, Kárpátmedencei, a korszakra vonatkozó adatokkal párhuzamba állítva a balatonkeresztúron tapasztalt jelenségeket, elképzelhető, hogy a felhagyása összefüggésben áll a kezdődő kis jégkorszak következtében a Balaton mentén is megváltozó környezettei feltételekkel (Mészáros-Serlegi 2011, 215.). 

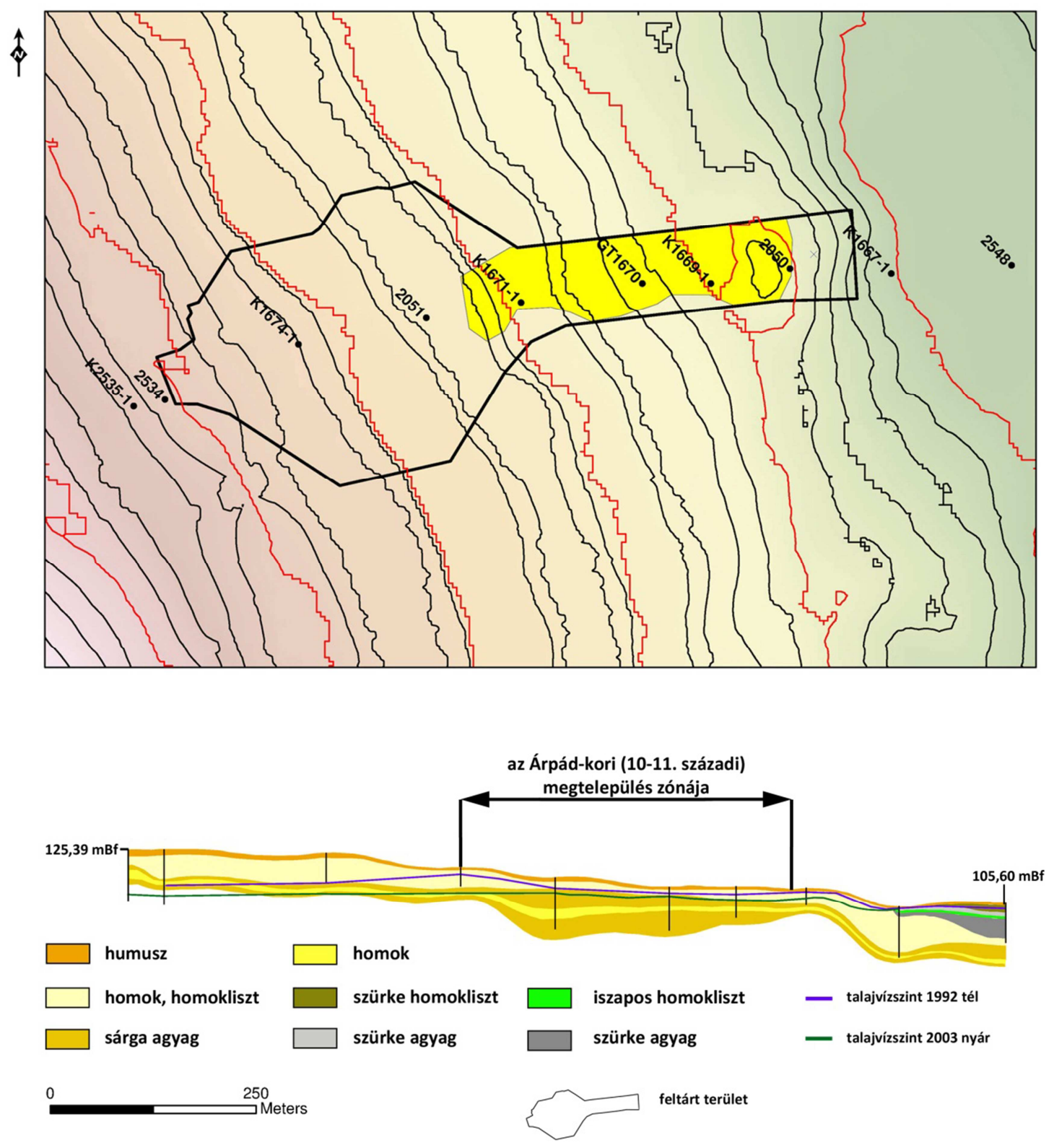

5.13. ábra. Az Árpád- kori megtelepedés zónája a balatonkeresztúri lelóhelyen 

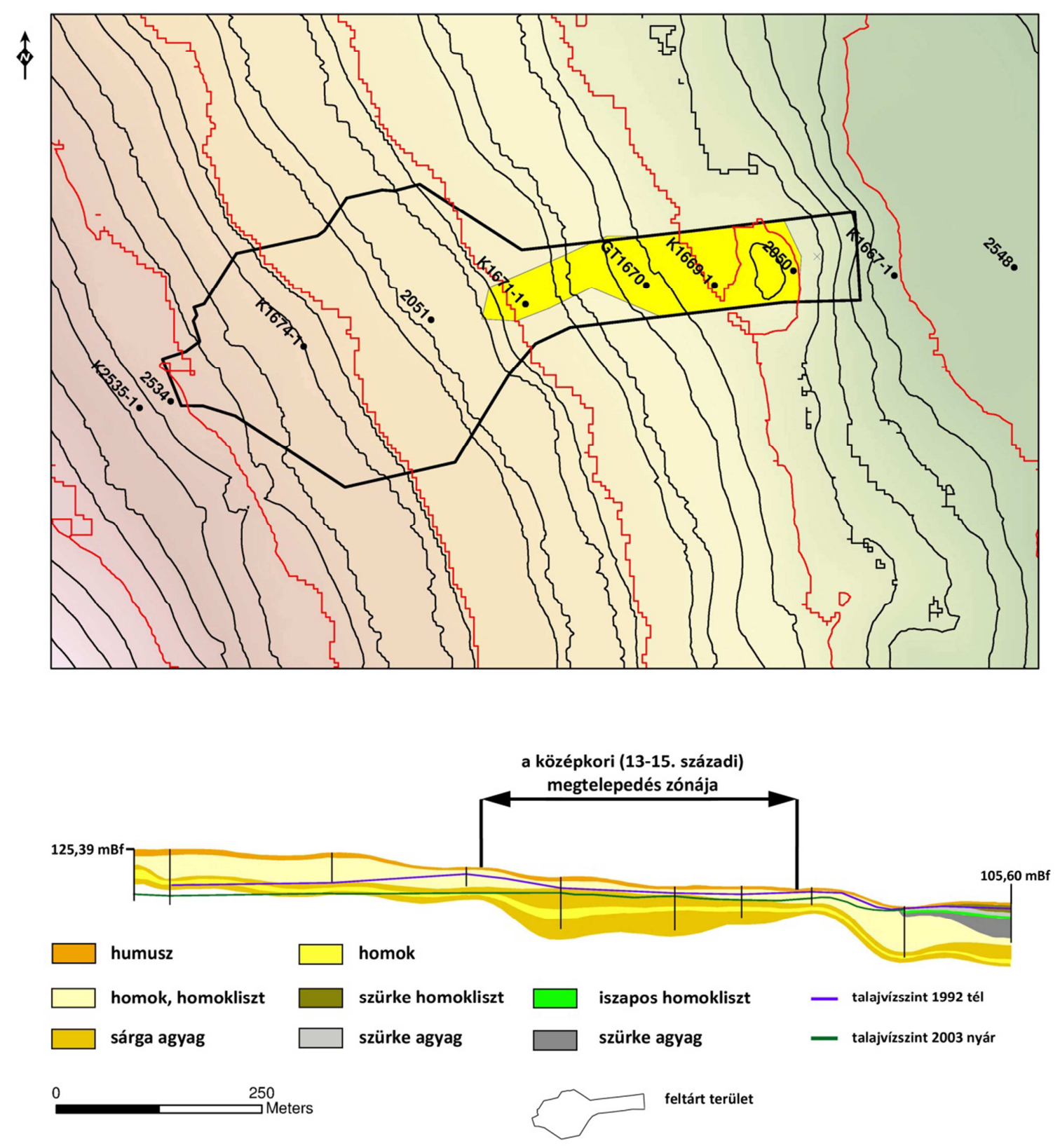

5.14. ábra. A középkori megtelepedés zónája a balatonkeresztúri lelőhelyen

\subsection{A talajvízmodell és a korszakonkénti megtelepedési zónák közötti összefüggések összefoglalása}

A balatonkeresztúri lelőhelyen a FŐMTERV által végzett talajmechanikai vizsgálatok eredményei alapján általam elkészített rétegtani és talajvíz modell, valamint a területen feltárt régészeti kultúrák időszakaihoz köthető települések megtelepedési zónái között kirajzolódó összefüggések alapján megfogalmazhatunk néhány megállapítást.

A hét régészeti korszakhoz kapcsolható megtelepedések közül hat (késő rézkor, kora és középső bronzkor, késő vaskor, népvándorlás kor, Árpád-kor és 

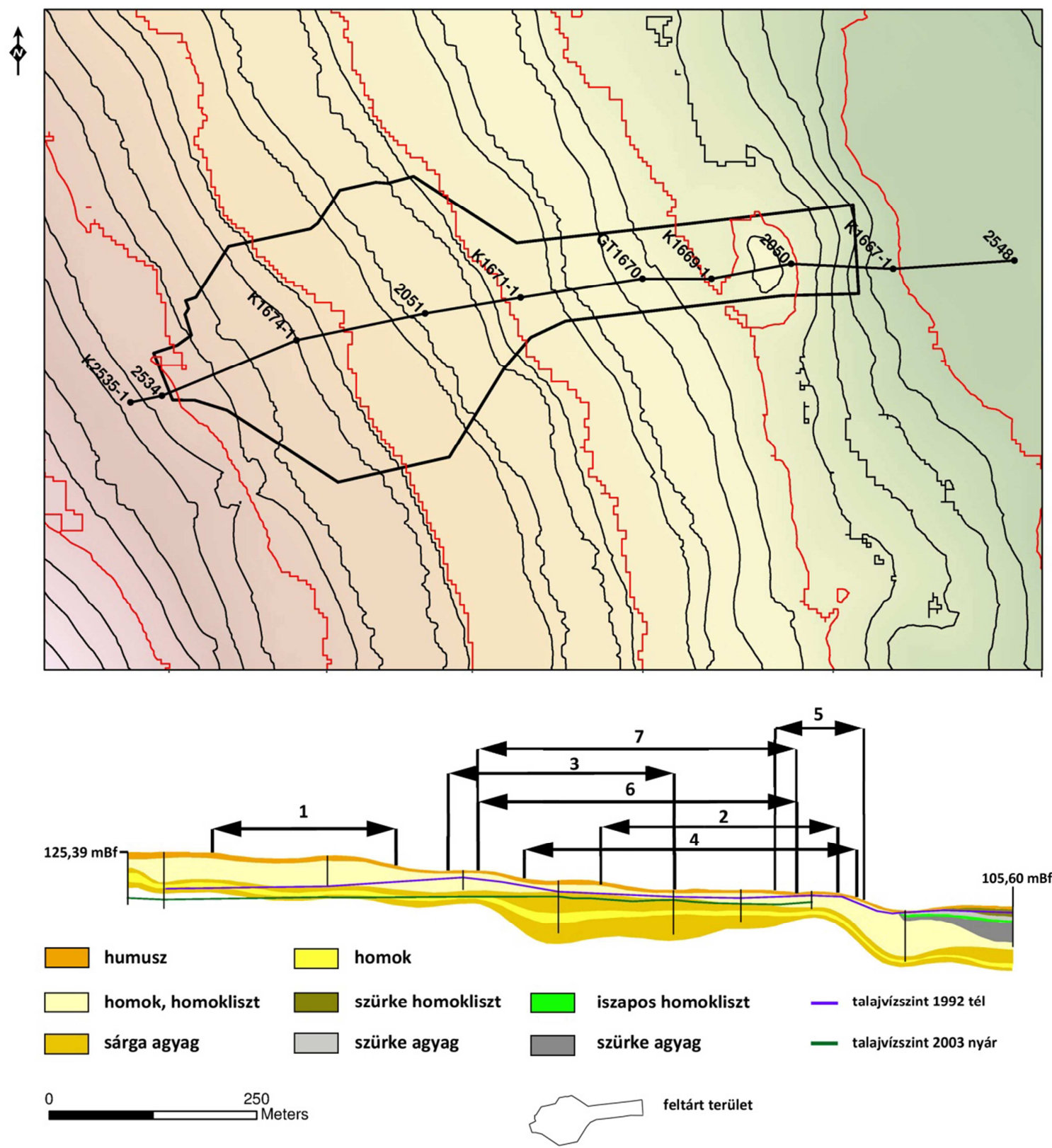

5.15. ábra. A megtelepedési zónák helyzete a balatonkeresztúri lelöhelyen: 1.

középső rézkor; 2. késő rézkor; 3. kora és középső bronzkor; 4. késő vaskor; 5. népvándorlás kor (Kr.u. 6. század); 6. Árpád-kor (10-11. század); 7. középkor (13-

\section{5. század)}

középkor) a lejtőnek azon a szakaszán található, ahol a talajvíztükör a mind a két balatoni vízállás esetén a felszínhez képest viszonylag csekély mélységben van (5.15. ábra). Tapasztalható némi eltérés azonban ezek között a megtelepedési zónák között is. A kora és középső bronzkor időszakának települése ennek a résznek is a felső régiójában található, a legmagasabb térszínen. A késő rézkor, az 
Árpád-kor és a középkor megtelepedései nagyjából azonos magasságú részeken találhatóak, de a késő rézkori telep gödrei megtalálhatóak a domboldal 108 méteres magasságú részein is, míg az Árpád-kori és középkori objektumok nem lépik át a vízszintes plató 110 méteres határvonalát. Ezzel szemben az utóbbi két korszak beásásai nyugati irányban a domboldalon majdnem a bronzkori megtelepedés legmagasabb szintjeivel vannak egy magasságban. Ezen a részen késő rézkori megtelepedés már nem volt észlelhető. A késő rézkori bolerázi időszakra, valamint az Árpád-kori jellemző szórt településszerkezettel szemben a késő rézkori második felében és a középkori idején a települések koncentrációja a 110-111 méter körüli magasságban lévő vízszintes platón alakul ki elsősorban. Két időszak, a késő vaskori és a Kr.u. 6. századi település objektumai intenzíven megtalálhatóak a plató alatti meredekebb domboldalon is egészen a Nagyberek széléig. A terület legalsó részén már a napjaink szabályozott vízállása mellett, és a Nyugati övcsatorna duzzasztó hatásával is számolva, de a feltárás időszakában is megfigyelhető volt a talajvíz felszíni megjelenése.

Az egyetlen kivétel a régészeti korszakok közül a középső rézkor időszaka, amelynek objektumai a terület legmagasabban fekvő részén voltak megfigyelhetők, ahol a talajvíztükör mélysége egyértelműen kizárja, hogy az objektumok bármikor is talajvíz hatása alá kerüljenek. A korszakhoz köthető kút mélysége alapján azonban, amely a terület legalacsonyabb részén került elő egy viszonylag alacsony talajvízszintet valószínűsíthetünk az időszakra. Ezért a Balaton-Lasinja kultúra megtelepedésének helye egyértelműen független a vízállástól. Felmerül ugyan ez a lehetőség a kora bronzkor időszakában. Mindaddig azonban, amíg az említett Balatonkeresztúr-Kiserdei-dűlőn tapasztalt kora bronzkori jelenségekről egyértelműen nem derül ki, hogy a vizsgált bronzkori megtelepedéssel azonos településhez tartoznak, addig a középső rézkori településre tett megállapításomat nem terjeszthetem ki erre az időszakra is.

A megfigyelések alapján elmondható, hogy a középső rézkor időszakát leszámítva a megtelepedések előnyben részesítették a lejtő középső (110-117 méteres magasságú) a vízszintes platóig tartó, és az alatta lévő (105-110 méteresmagasságú) legalsó szakaszát, ahol a talajvíz a felszín viszonylagos közelségében van. A modernkori vízállás adatok és a talajvíztükör változása 
között tapasztalható összefüggés alapján megállapíthatom, hogy a Balaton vízszintjében bekövetkezett 0,7 méteres vízállásváltozás esetén a talajvíztükör egyes szakaszain ugyan feltételezhető jelentősebb eltérés, azonban az intenzíven lakott zónában ebben az esetben az ingadozás nem jelentős, valamint a rendkívül alacsony $(103,76)$ méteres szint esetén sem süllyed túl mélyre. Ebben az esetben felmerül a Nyugati övcsatorna visszaduzzasztó hatása. Az adatok alapján, ebben az időszakban a csatornában is rekord alacsony, 104 méter alatti vízállásokat mértek (legalacsonyabb vízállás a Nyugati-övcsatornában 103,57 mBf 2003.10.07) ${ }^{13}$.

A már részletesen feldolgozott késő rézkori megtelepedés több tényezőt vizsgáló komplex feldolgozásának ismeretében egyértelműen látszik, hogy egy hosszabb ideig tartó megtelepedés ideje alatt a tó vízállásában nagymértékű, a talajvíztükröt jelentősen befolyásoló változás nem állhatott be. Annak ellenére sem, hogy a badeni kultúra három, egymást követő fázisában a stabilizotóp geokémiai adatok alapján jól bizonyíthatóan egy rövidebb ideig tartó szélsőséges karakterű éghajlati időszak, majd egy rövid idejű, csapadékos szakasz után fokozatos visszarendeződés tapasztalható az éghajlati körülményekben. A bolerázi és a klasszikus badeni időszak határán, vélhetően részben ennek az éghajlati ingadozásnak a hatására karakterisztikus változás megy végbe a közösségek anyagi kultúrájában és gazdálkodásában (Fábián-Serlegi 2009, 215218; Serlegi et al. 2012, 142-144.). Ez alatt az időszak alatt a településszerkezet átrendeződik, az objektumok koncentrációja a vízszintes platón a környező területekhez képest megnövekszi, de a megtelepedési területet nem adják fel a domboldalon. Minthogy a domboldalnak ez a szakasza a tó természetes állapotában több esetben, hosszabb időszakokon keresztül is lakott volt, szinte nagyvalószínűséggel kijelenthetem, hogy néhány évszázados intervallumban a tó vízszintje az 1-2 méteres vízingadozást nem haladta meg, mert az már olyan mértékű változásokat okozott volna a talajvíztükör mélységében, ami alapvetően befolyásolta volna a település létét. Valamint valószínűsíthető, a késő rézkori adatok alapján, hogy a kisebb amplitúdójú klímaesemények a tó vízállásában nagymértékű változást nem okoztak. Arra vonatkozóan, hogy bármelyik korszak

${ }^{13}$ (http://www.vizugy.hu/?mapModule=OpGrafikon\&AllomasVOA=A48DE6CE-7734-4681-A95682F432E541B1\&mapData=Idosor) 
települése a tavi vízszintnek és a talajvíztükörnek a kritikus érték fölé emelkedése miatt szűnt volna meg, jelenleg nem rendelkezünk elegendő információval.

A lejtő legalsó részét (106 méteres magasságig), elfoglaló két időszakban (késő vaskor, Kr.u. 6. század) a tengerszint feletti adatok alapján egy viszonylag alacsonyabb alacsony tavi vízszintet feltételezhetünk. Legalábbis alacsonyabbat, mit azoknak az időszakoknak az esetében, amikor a 110 méteren lévő vízszintes plató vonalát és annak környékét a fölbemélyített objektumok nem lépik át.

Az említett intervallumnál nagyobb vízemelkedésre a balatonkeresztúri lelőhelyen közvetlen adatunk nincsen. Elképzelhető, hogy a magasabb vízállású periódusokra egyes időszakok hiánya utalhat. A már korábban említett Ordacsehi-Kistöltés lelőhelyen feltárt késő bronzkor végére, kora vaskor elejére keltezhető árokban észlelt 107,3 méterig emelkedő vízszint esetleg a balatonkeresztúri domboldalon olyan magas talajvíztükröt eredményezett volna, hogy a domboldal középső és alsó régiói alkalmatlanok lettek volna a megtelepedésre (Sümegi et al. 2004, 410-411; Sümegi et al. 2007, 251-252.). Ennek a feltételezésnek a bizonyítására csak akkor lenne lehetőség, ha lennének a balatonkeresztúri vizsgálatokkal megegyező elemzések több lelőhelyről, olyanokról is ahonnan késő bronzkori és kora vaskori leletanyag is előkerült.

Végezetül ki kell még egyszer térnem a Nyugati-övcsatorna talajvízviszonyokra gyakorolt hatására. Feltételezhető, hogy napjainkban a talajvíztükör mindenkori szintjére a csatorna vízállása nagyobb hatással van, mint a tó nyílt víztükrének magassága. Így a talajvíztükör tengerszint feletti értékének meghatározására a Balaton vízállásának függvényében csak akkor lenne lehetőség, ha több, azonos helyen, de eltérő időpontokban végzett mintavételezések nyugalmi talajvízszint adatait és a Balaton, valamint a Nyugati övcsatorna aktuális vízszintjével nagyobb mintaszámú adatsoron értékelnénk. Mindaddig, amíg ez nem történik meg, addig a balatonkeresztúri lelőhely régészeti és talajvíz adatai alapján csak tendenciákat tudunk meghatározni a régészeti korszakokra, a tó egykori vízállásának és ezzel összefüggésben a talajvíztükör tengerszint feletti magasságának megállapítására nem alkalmas. 


\subsection{A balatonkeresztúri lelőhely régészeti korszakainak abszolút kronológiája}

A balatonkeresztúri lelőhely azon régészeti korszakaiból, amelyek az első, római kori antropogén eredetű környezet átalakítás időpontját megelőzték rendelkezünk radiokarbon adattal. A legnagyobb számban a feldolgozásban leginkább előrehaladott késő rézkor idejére vonatkoznak, ebből a korszakból a kultúra alfázisairól is rendelkezünk megfelelő számú adattal. A középső rézkorból, a kora és középső bronzkorból, valamint a késő vaskorból egy-egy adat áll rendelkezésünkre.

A mérések mindegyike a bécsi VERA - Vienna Environmental Research Accelerator laborban készül, állati és emberi csontokból. Az eredményeket az 5.16. ábrán összesítettem.

\begin{tabular}{|c|c|c|c|}
\hline laborszám & uncal BP & $\begin{array}{c}\text { cal BC } \\
(68,2 \%)\end{array}$ & korszak \\
\hline VERA-5460 & $5320 \pm 35$ & $4235-4060$ & középső rézkor \\
\hline VERA-4221 & $4645 \pm 35$ & $3500-3360$ & késő rézkor \\
\hline VERA-4222 & $4665 \pm 35$ & $3520-3370$ & késő rézkor \\
\hline VERA-4223 & $4655 \pm 35$ & $3510-3360$ & késő rézkor \\
\hline VERA-4226 & $4545 \pm 30$ & $3370-3120$ & késő rézkor \\
\hline VERA-4227 & $4515 \pm 35$ & $3350-3110$ & későrézkor \\
\hline VERA-4228 & $4385 \pm 30$ & $3080-2920$ & késő rézkor \\
\hline VERA-4229 & $4405 \pm 25$ & $3090-2930$ & késő rézkor \\
\hline VERA-4230 & $3455 \pm 35$ & $1875-1690$ & kora-középső \\
& & & bronzkor \\
\hline VERA-4225 & $2210 \pm 30$ & $360-205$ & késő vaskor \\
\hline
\end{tabular}

5.16. ábra. A balatonkeresztúri őskori régészeti kultúrák abszolút kronológiai adatai

Habár a késő rézkor időszakát leszámítva a balatonkeresztúri megtelepedés régészeti időszakainak rövidebb idejű szakaszairól nem rendelkezünk információval, a megtelepedések abszolút kronológiai időpontja 
támpontot adhat egy környezettörténeti vizsgálat rétegsorának radiokarbon keltezésével való összehasonlításra. 


\section{A balatonkeresztúri lelőhely és a Nagyberek környezettörténeti rekonstrukciójának problematikája}

\subsection{A mintavételezés helyszíne}

Az előzetes terveknek megfelelően a balatonkeresztúri lelőhelytől északkeleti irányba 900 méteres távolságban a Nagyberek területén 2005 februárjában mintavételi szándékkal térképező üledéktani fúrást mélyítettünk (fúráspont koordinátái, EOV_x: 523089.70; EOV_y: 151113.95). A kiválasztott terület a Nagyberek egy mélyebb területén, a Nyugati-övcsatorna keleti oldalán volt, megfelelő távolságban az addigra már megépült autópálya nyomvonalától, a kivitelezési munkálatok által sem érintett területrészen (6.1. ábra). A munkálatokat a Szegedi Tudományegyetem Földtani és

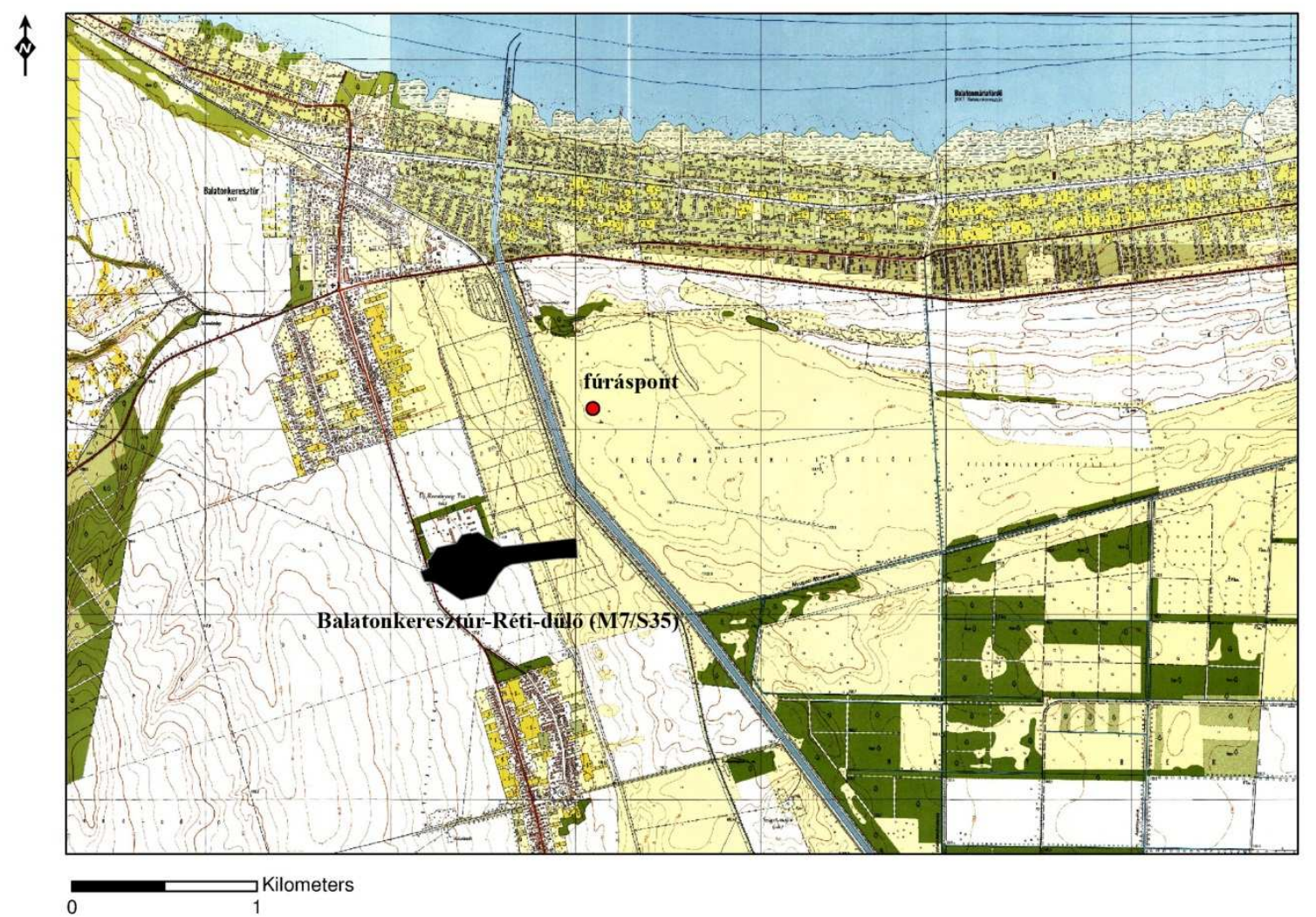

6.1. ábra. A balatonkeresztúri mintavételi pont és a lelőhely helyzete

Őslénytani Tanszékének szakemberei végezték Dr. Sümegi Pál vezetésével. A 2,8 méteres mélységig hatoló, zavartalan magfúrást a helyszínről kiértékelésre az egyetem Geoarchaeológiai és környezettörténeti laboratóriumába szállítottuk, ahol szakszerű tárolási körülmények között készítették elő az értékelő vizsgálatokra. A tervbe vett, és a 
rétegsoroknak a régészeti adatokkal való összevetése szempontjából elsődleges fontosságú radiokarbon keltezésére az anyagi források szűkössége miatt azonban sajnálatosan a mai napig nem kerülhetett sor, ami a fúrásminta teljes kiértékelését nem teszi lehetővé.

\subsection{A fúrásminta palinológiai értékelésének módszere}

A fúrásmag pollenanalitikai vizsgálata a Szegedi Tudományegyetem Földtani és Őslénytani Tanszékének Geoarchaeológiai és környezettörténeti laboratóriumában készült Lycopodiumos módszerrel, 4 centiméteres felbontásban. A vizsgálatokat Nagyné Bodor Elvira végezte. A dolgozat elkészültéig egyelőre publikálatlan, teljes jelentését a dolgozat 2. számú melléklete tartalmazza14.

\subsection{A vizsgálati eredmények rövid összefoglalása}

A kiértékelt fúrásmag üledéktani rétegsorának fejlődése, egymást váltó tőzeg, eutróf és mezotróf tavi üledékek alapján, összehasonlítva korábbi balatoni fúrások radiokarbon módszerrel keltezett üledékrétegeivel, lefedi az elmúlt 10.000 év fejlődéstörténetét. A fúrásban tapasztalható változások folyamata és a palinológiai azonosságok alapján a vizsgálatot végzők a fúrás teljes mélységét 6 zónára tudták felosztani: késő Boreális, Atlantikus 1, Atlantikus 2, Szubboreális, Szubatlantikus 1 és Szubatlantikus 2. Jelen pillanatban a vizsgált fúrás szerves maradványaiból vett minták radiokarbonkeltezésének hiányában ennél részletesebb felosztásra és a megfigyelt jelenségek, tendenciák abszolút dátumokkal való összekötésére nincsen mód.

Ennek ellenére az értékelés alapján jól megfigyelhető a szárazföldi és a vízi növényzet változásaiból, hogy a fúrásmag által lefedett időszakban a Balaton, illetve a Nagyberek a vízborítása rendszeresen ingadozott, területén nyíltvízi és a mocsaras környezet váltakozott. A tó vize a mezotróf és eutróf állapotok között változott. Az üledékekben a növényi maradványok alapján azonosítani lehetett a változó intenzitású emberi tevékenység nyomait is.

\footnotetext{
${ }^{14}$ A lehetőségért, hogy a publikálatlan vizsgálati eredményeket a disszertációmban felhasználhatom Nagyné Bodor Elvirának és Dr. Sümegi Pálnak egyaránt köszönettel tartozom.
} 
A növényi maradványok elemzése alapján a tó vízborításának jellege és a víz tápanyagtartalmát jelző fajok elterjedése alapján a víz minőségének változása röviden így foglalható össze.

A késő Boreálisban mezotróf, nyíltvízi állapotok uralkodtak, a nyílt víztükröt Sphagnum láp vette körül. Ezt követően az Atlanikus 1 elején eutróf jellegű tó vélhetőleg mezotróf jelleget ölt, egyes fajok eltűnése alapján sekélyesedésre lehet következtetni. Felszaporodnak a mezotróftól-eutrófig terjedő életkörülményeket jól viselő fajok. Az időszak végére újból megjelennek a nyíltvízi körülményeket, és a vízparti életteret kedvelő hínárfajok, ami a vízszint emelkedésére utal. Az Atlantikus 2-ben a nyíltvízre jellemző hínárok számaránya megnövekszik, valamint jól követhetően nő a víz trofitása is. Ebben az időszakban már azonosíthatóak gabonafélék pollenei, ami kiterjedt agrártevékenységet tükröz. A Szubboreálisban csak a nagyon sekély vízre utaló növényi maradványok találhatóak a fúrásminta rétegeiben. A Szubatlantikus 1 időszakában a vízi növényzet annyira megritkul, hogy százalékos értékelésre alkalmatlan. A kezdeti időszakban még kevés, elsősorban eutrof körülményeket kedvelő vízinövény faj még előfordul, amelyet jelentős láposodás követ. A Szubatlantikus 2-ben a vízborítás teljes mértékben eutóf jellegű, a jelentős lápi hatás érvényesül a mintákban.

A rövid összefoglalásból is egyértelműen látszik, hogy a vizsgált időszakban, amely teljes mértékig lefedi a balatonkeresztúri lelőhelyen megtelepedett régészeti korszakok időszakait is, a tó vízborításában és vízminőségében a vízi növényzet összetétele alapján is jelentős ingadozásokat lehet kimutatni.

A Dunántúl környezeti képének változásait vizsgáló kötetben (EnvArc 2007.), Juhász Imola készítette el a Kis-Balaton medencéjében végzett környezetrekonstrukciós fúrásminták rétegsorainak korrelációját (Juhász 2007, 36-51.). A felhasznált, és regionális szinten a lehetőségekhez mérten egységes módszer alapján vizsgált mintavételek közül a Kis-Balaton keleti szélén mélyített főnyedi fúrás van térben a legközelebb a balatonkeresztúri mintavétel helyszínéhez (Szántó-Medzihradszky 2004, 691-699; Medzihradszky 2005, 77-100). A balatonkersztúri minta szárazföldi és vízi növényzet alapján megállapított pollenzónái és a főnyedi fúrás radiokarbon módszerrel datált rétegei abban az esetben lennének korrelálhatók, ha a balatonkeresztúri fúrás mintáiból rendelkeznénk abszolút kronológiai dátumokkal. Ebben az esetben a balatonkeresztúri rétegsor beilleszthető a lenne a Balaton nyugati medencéjének fejlődéstörténetébe. Ezek hiányában, valamint a némileg eltérő földrajzi környezett 
miatt komolyabb következtetést azonban nem lehet levonni annak ellenére sem, hogy a domináns fafajták (Corylus, Quercus, Fagus, Tilia, Ulmus) megjelenési és csúcsidőszakaiban, illetve változásaik tendenciáiban kimutatható egyfajta hasonlóság. A radiokarbon módszerrel keltezett rétegsorok hiánya ezen felül azt sem teszi lehetővé, hogy a Balaton, illetve a Nagyberek mintavétel alapján kimutatható vízborítási tendenciáit összehasonlítsam a balatonkersztúri lelőhelyen feltárt régészeti korszakok megtelepedési viszonyaival. Valamint, hogy egyes korszakok hiányát közvetett bizonyítékként használva a magasabb vízállási korszakokra fényt derítsünk. A felmerülő kérdések tisztázása egy későbbi tudományos kutatás feladata lehet. 


\section{A statikus vízkitöltési modell}

A balatonkeresztúri lelőhelyen elvégzett, a Balaton vízszintje által befolyásolt talajvíztükör mozgásnak a régészeti kultúrák megtelepedési viszonyaira gyakorolt hatását igazolandó, egy nagyobb területen elemeztem a települések elhelyezkedését a Balaton partvonalának közelében. Az elemzés ebben az esetben csak a tavat ért első, római kori jelentősebb antropogén hatás előtti időszakra korlátoztam.

\subsection{A kiválasztott terület}

A vizsgált, 36 kilométerszer 24 kilométer nagyságú, valamivel több, mint 860 négyzetkilométer kiterjedésű terület a Balaton nyugati végét a Nagyberekkel,

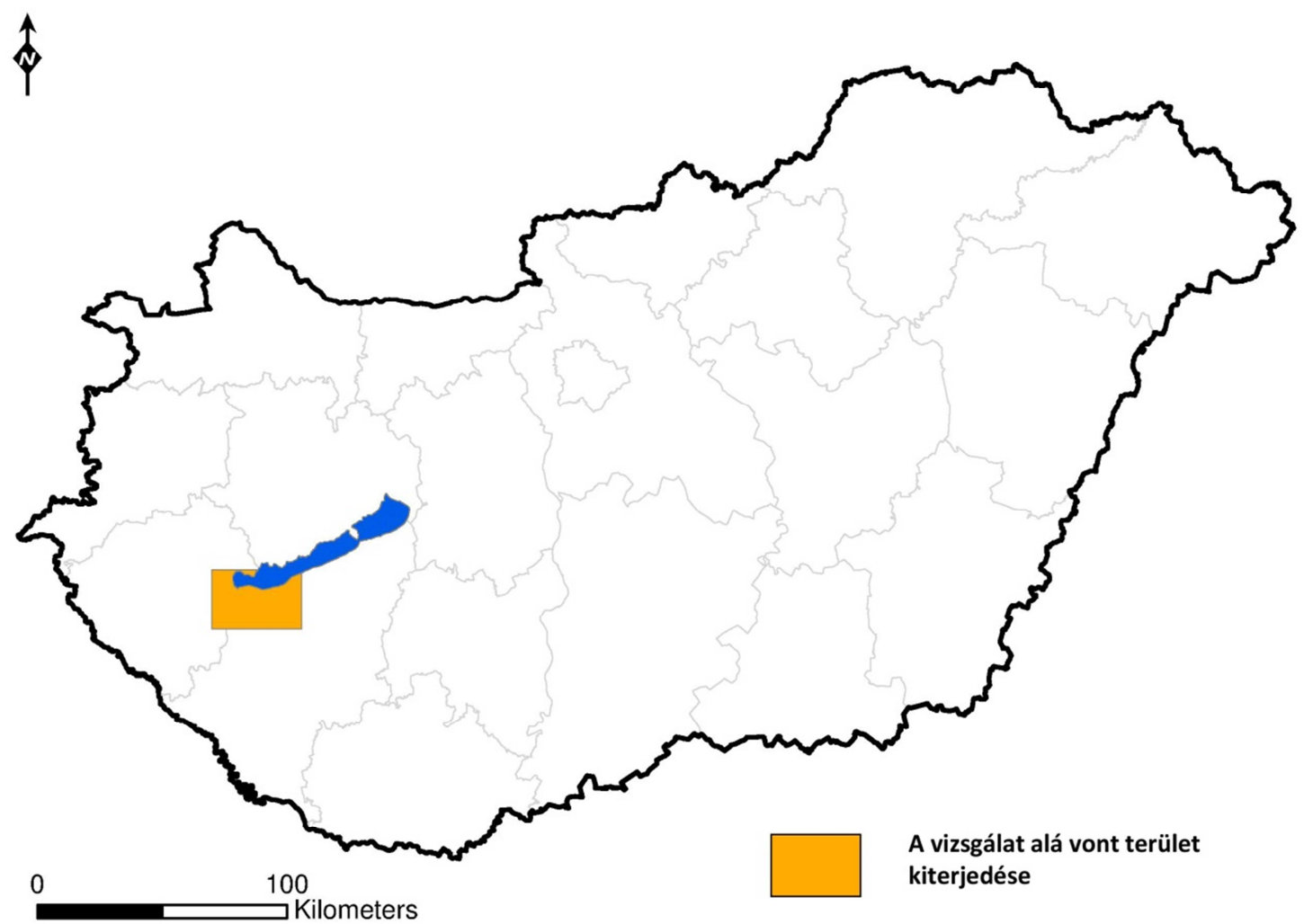

7.1. ára. A vizsgálat alá vont terület helye és kiterjedése

a Marcali-löszhát északi részét, valamint a Kis-Balaton medencéjének keleti felét fedi le (7.1. ábra). A terület kiválasztását elsősorban az indokolta, hogy a 
balatonkeresztúri lelőhely közeléből erről a területről rendelkezünk publikált és digitalizálható, térinformatikailag értelmezhető régészeti topográfiai adatokkal. Köszönhető ez a Magyarország Régészeti Topográfiája sorozat, a keszthelyi és tapolcai járás lelőhelyeit feldolgozó kötetének (MRT 1966.), és a Kis-Balatonrekonstrukció során elvégzett feltárások összefoglaló publikációinak (Évezredek 1996.), valamint az M7 autópálya érintett szakaszának megelőző feltárásairól kiadott előzetes jelentéseknek (Honti et al. 2004, 3-70; Honti et al. 2007, 7-70.). A területre vonatkozó egyéb adattári anyag beépítése a vizsgálatba, térképi ábrázolások, vagy még pontosabb koordinátával rendelkező adatok hiányában nem volt lehetséges.

\subsection{A modell létrehozása során használt módszerek}

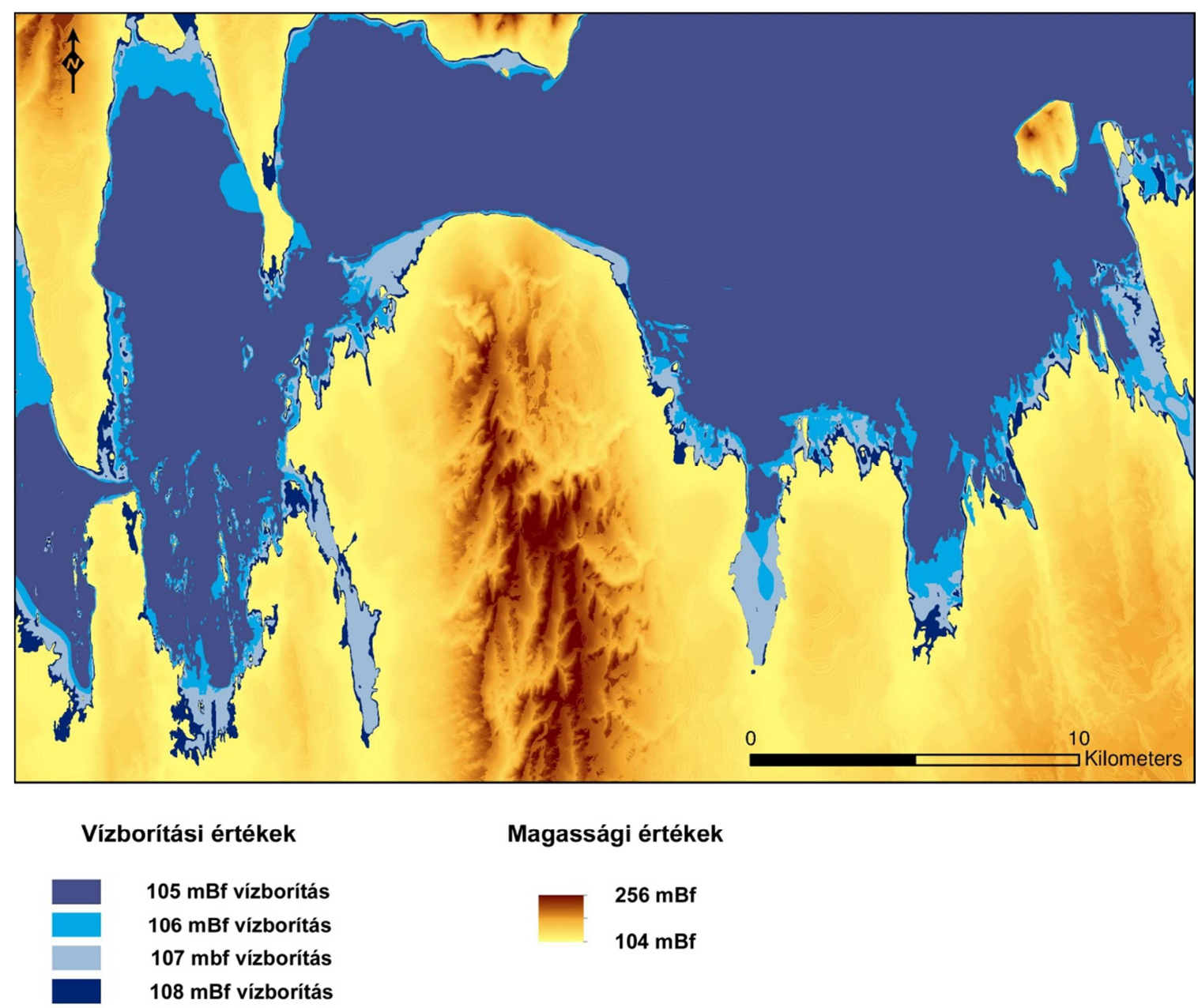

7.2. ábra. A vizsgált terület digitális domborzatmodellje a vízborítási értékek korrigált poligonjaival 


\subsubsection{A vízborítás modellezése}

Az elemzés alapját a DDM10-es 10 méter vízszintes felbontású digitális domborzatmodell szolgáltatta (Tímár et al. 2010, 457.), amelyet újraosztályoztam (ArcGIS -ArcMap 10.2 Reclassify tool) oly módon, hogy olyan állományokat kapjak, amelyek a 105, 106, 107, 108 méteres Balti-magasságú területeket lefedik. Az így kapott raszteres állományokat poligonná konvertáltam (ArcGIS ArcMap 10.2 - Raster to polygon tool). Minthogy a DDM10-es digitális domborzatmodell az 1:50.000 méretarányú katonai térképek 5 méteres alap szintvonalainak digitalizált állományán alapul (Tímár et al. 2010,457.), így az újraosztályozott állomány sok estben korrekcióra szorult a terület alacsony lejtési viszonyai miatt. A vizsgálat esetében 1 méteres szintkülönbségű vízállások

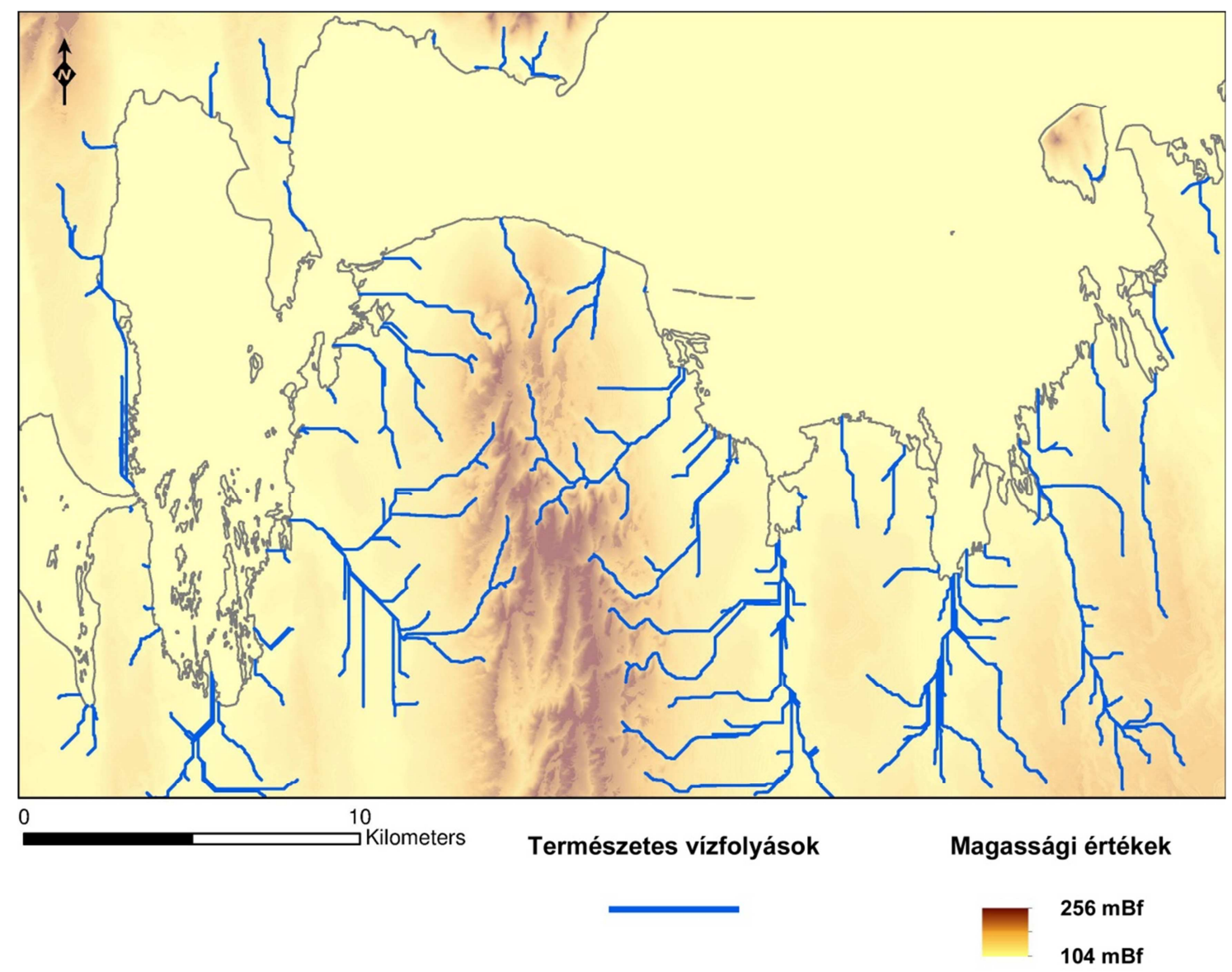

7.3. ábra. A természetes vízfolyások digitális domborzatmodell alapján előállított hálózata a tó 105 mBf vízborítása esetén 
által lefedett területi kiterjedésének rekonstrukciójára volt szükség ezért a digitális domborzatmodell által kínált 5 méteres függőleges irányú felbontás nem volt elégséges. A poligonok határa nem illeszkedett az 1:10.000-es méretarányú topográfiai térkép szintvonalaira. Ennek korrigálására a poligonokat rávetítettem megfelelő, digitalizált térképlapokra, amelyek 1 méteres alapszintvonalai alapján módosítottam a poligonok határait, kialakítva így négy darab, 1 méter szintkülönbségű statikus vízborítási modellt (7.2. ábra). A poligonok korrekciójának során nem vettem figyelembe a Nagyberek és a tó déli partja között húzódó turzás és a feltöltött part menti részek napjainkban már teljesen mesterséges domborzati viszonyait.

\subsubsection{A felszíni vízfolyások modellezése}

A különböző magasságú vízállás esetén vízzel borított területek meghatározását követően a digitális domborzat modell alapján meghatároztam a domborzatból adódó vízlefolyási irányokat. Ennek során az ArcGIS - ArcMap 10.2 - flow accumulation tools alkalmazása után a kapott raszteres állományt újra osztályoztam oly módon, hogy a vízfolyás alsó határértékét 5.000-ben határoztam meg. Vagyis minden olyan tízszer tíz méteres rasztert vízfolyásnak tekintettem, amelyikbe minimum 5.000 különböző másik raszterből „folyik” össze a víz. Az így kirajzolódó vízfolyások jól mutatják a Marcali-hátról, a Zalavári-hátról és a Somogyi-dombság északi, Nagyberek felé néző lejtőiről a tóba folyó természetes vizek folyásirányát (7.3. ábra).

\subsubsection{A domborzati sajátosságok modellezése}

A felszíni hidrológia modellezése után elkészítettem a terület lejtőkiettségi elemzését (ArcGIS - ArcMap 10.2 - slope tool), amelyre azért volt szükség, hogy a viszonylag alacsony domborzati reliefen belül, a lejtőértékek újraosztályozásával meghatározhatóak legyenek a megtelepedés szempontjából meredekebb és kevésbé meredek lejtők (7.4. ábra). 


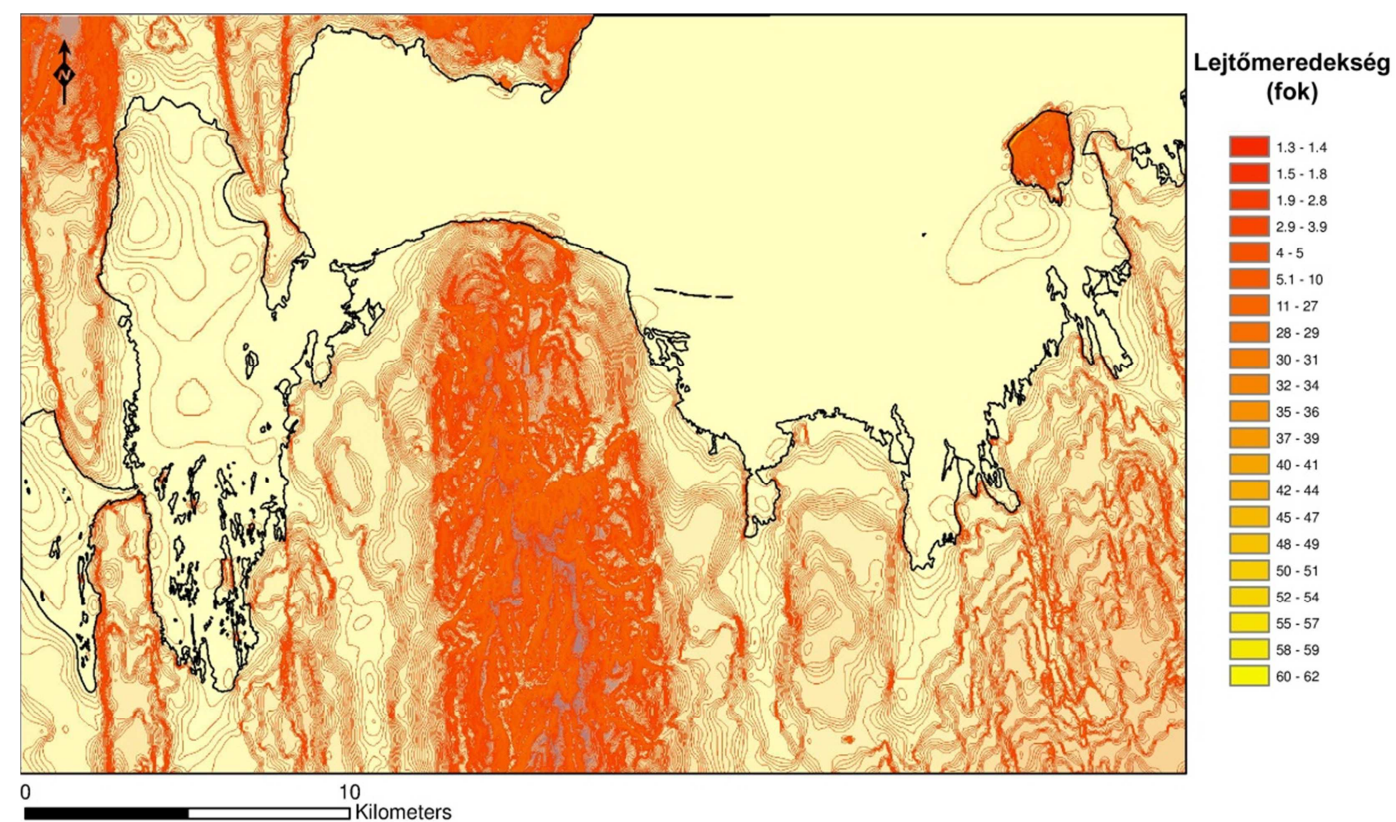

7.4. ábra. A vizsgált terület lejtökitettségi térképe és a 105 mBf vízborítás kiterjedésének határa

\subsubsection{Az üledékviszonyok, a talajtakaró és a felszín alatti hidrológia modellezése}

Ezt követően, a térinformatikai állományba importáltam a vizsgált terület 1:100.000 méretarányú földtani térképnek (7.5. ábra), a talajvízmélység (7.6. ábra), illetve a talajtakaró területre jellemző talajtípusainak elterjedését mutató térképek (7.7. ábra) georeferált állományát ${ }^{15}$.

${ }^{15} \mathrm{~A}$ terület földtani térképe a MÁFI 1:100.000 léptékű földtani térképműve (forrás: http://loczy.mfgi.hu/fdt100/) , a talajvízmélység térkép pedig a MÁFI 1:100.000-es méretarányú, a 0-8 méter mélységú talajvíz térképmúve alapján készült (forrás: http://loczy.mfgi.hu/tvz 1248/).A talajtípusokat összefoglaló térképi ábrázolás az MTA ATK TAKI szintén M:1:100.000-es léptékü AGROTOPO térképmű területre vonatkozó része alapján készült (forrás: http://maps.rissac.hu/agrotopo/). 


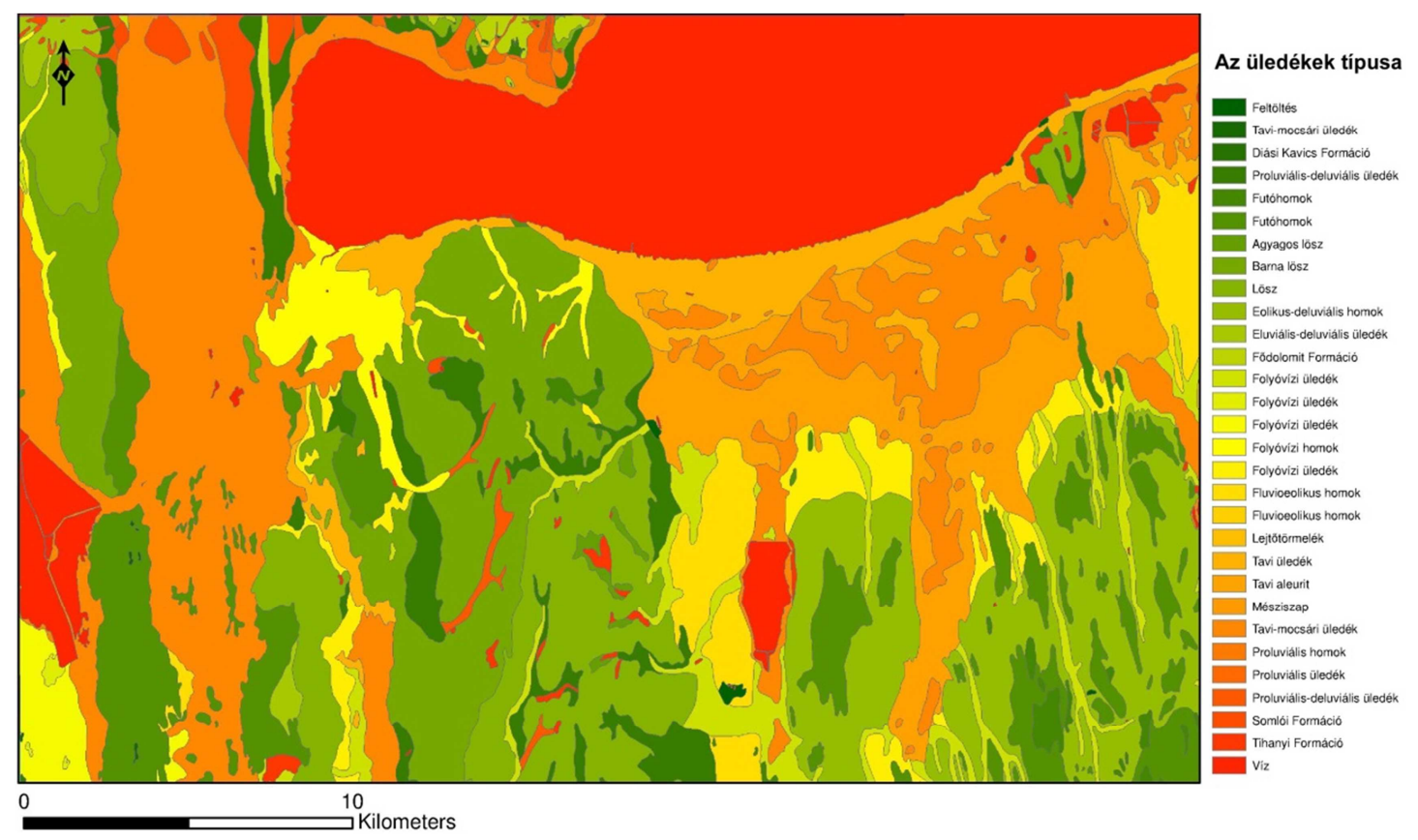

7.5. ábra. A vizsgált terület üledékföldtani térképe (forrás: http://loczy.mfgi.hu/fdt100/)

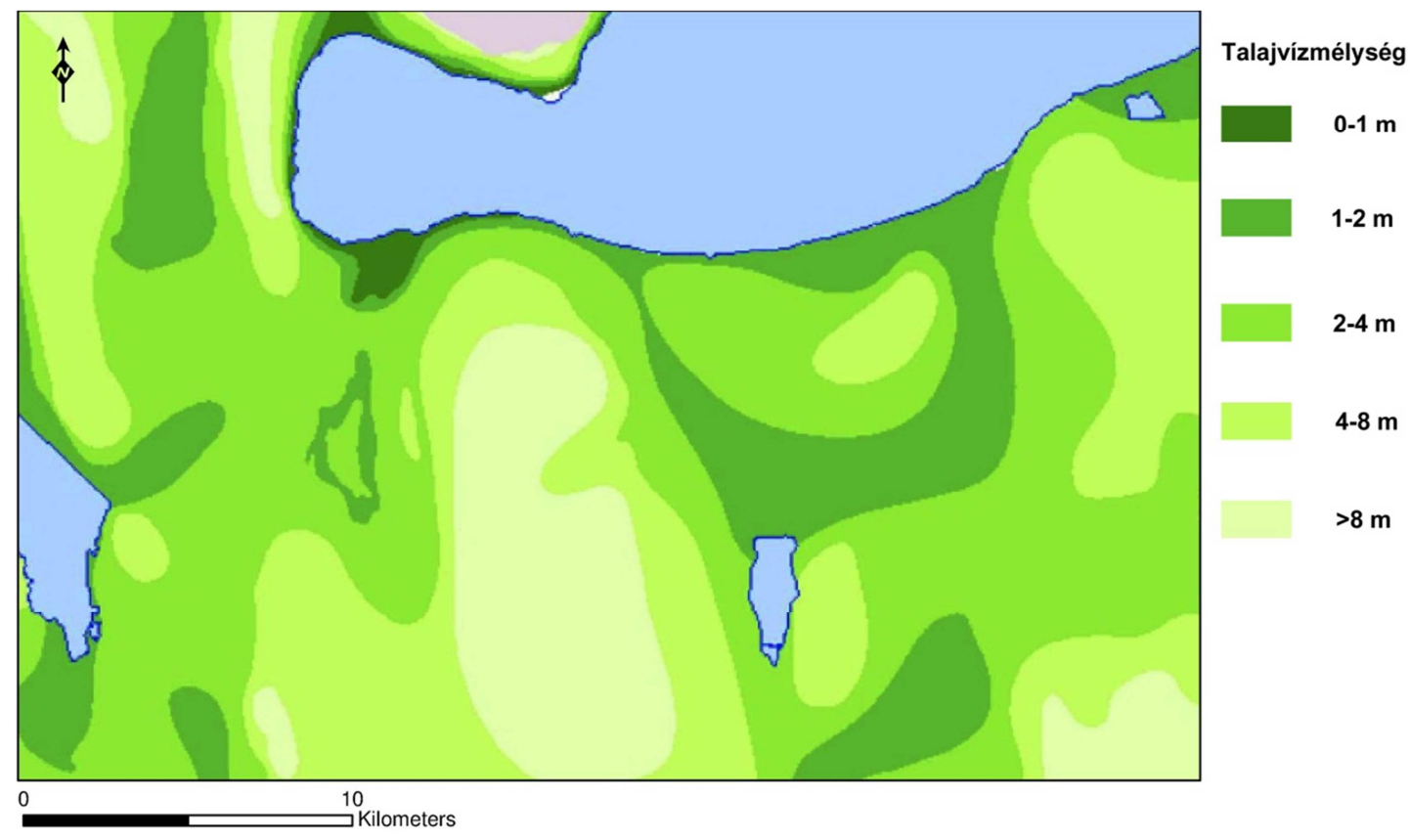

7.6. ábra. A vizsgált terület talajvízmélységét bemutató térkép (forrás: http://loczy.mfgi.hu/tvz 1248/) 


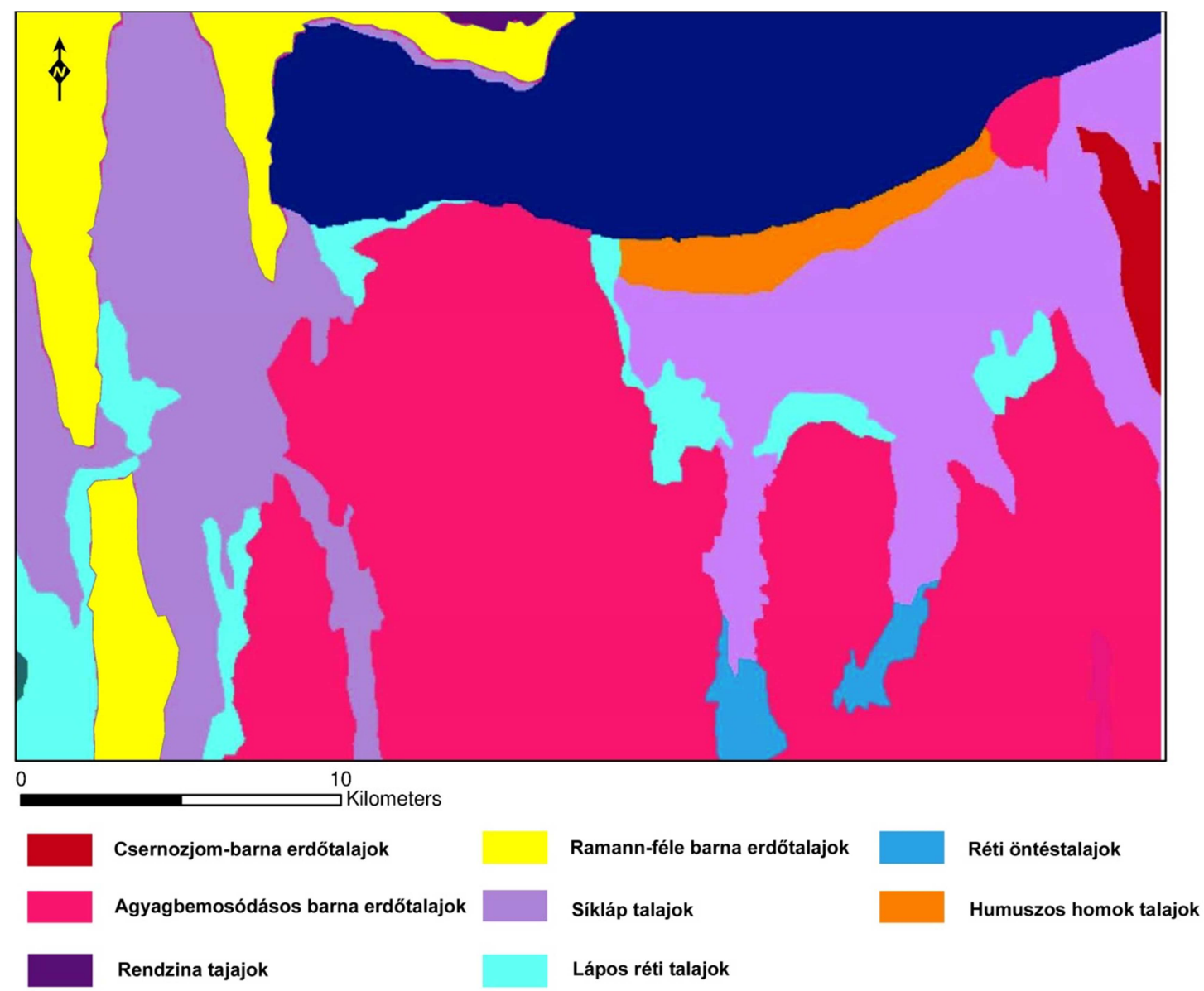

7.7. ábra. A vizsgált terület talajtakaró térképe

(forrás: http://maps.rissac.hu/agrotopo/)

\subsubsection{A régészeti lelőhelyek állományának integrálása}

Utolsó lépésként integráltam a modellbe a vizsgált terület régészeti szakirodalomból ismert lelőhelyállományát. A lelőhelyek és a lelőhelyeken talált feltárt régészeti korszakok részletes listáját a dolgozat 3. melléklete tartalmazza.

A modellalkotás végeredményeként előállítottam egy olyan térinformatikai állományt, amely a lelőhelyek összesítő pontállománya mellett összekapcsolja a vizsgált területen a felszín tengerszint feletti magasságára, domborzati és üledékföldtani jellegére, valamint a felszíni vízborítás és a vízfolyások elhelyezkedésére, a talajvízszint átlagos mélységére és a települést körülvevő, hasznosítható területek talajtípusaira vonatkozó adatokat. Ezek azok az alapvető változók, amelyek általában meghatározzák a települések 
elhelyezkedését egy adott tulajdonságokkal rendelkező területen belül (van Leusen et al. 2009, 138-143; Mesterházy-Stibrányi 2011, 13-16; Stibrányi et al. 2012, 28-39.).

\subsection{A modellből levonható általános következtetések}

Az elemzés első lépéseként az összes - a már korábban említett források alapján - felgyűjtött lelőhelyet, a megtalálható korszakoktól függetlenül együttesen kezeltem, igyekeztem kideríteni azokat a meghatározó tényezőket a települések helyének kialakításánál, amelyek általánosnak mondhatóak minden korszakban. Hozzá kell azonban tennünk, hogy a regisztrált lelőhelyek nagy részének pontos elhelyezkedéséről, kiterjedéséről nincsenek adataim, többségük mindössze pontszerű adat. Ezeknek az adatoknak is csak egy kis része, az M7 autópálya nyomvonalába eső lelőhelyek rendelkeznek valós EOV koordinátákkal, a kis-balatoni lelőhelyek esetében a visszaazonosításuk a publikáció térképmelléklete és az 1:10.000-es térképlapok szintvonalainak összevetése alapján történt. Az állomány pont jellege miatt, amelyben minden egyes lelőhelyet mindössze csak egy pont jelöl, valamint a terület arányaiból adódóan a modell tartalmaz egy bizonyos szintű bizonytalanságot. A modell pontosságát nagyban növelné, ha a lelőhelyek integrált állományát nem egy-egy pont, hanem sarokpontjain három koordinátával rendelkező poligonok alkotnák, amelyek megadnák a lejtőkön való pontos elhelyezkedést és kiterjedést. A lelőhelyek területi visszaazonosítása és a kiterjedésük térinformatikailag is értelmezhető meghatározása a dolgozat kereteit meghaladja, ennek elvégzése egy későbbi kutatás feladata lesz.

Így a pontos kiterjedésük és geomorfológiai helyzetük ismeretének hiányában a lelőhelyek elhelyezkedését nem lehet minden tekintetben összehasonlítani a balatonkeresztúri lelőhely részletes elemzéseivel (FábiánSerlegi 2007, 2009; Demény et al. 2010; Serlegi et al. 2012; Schöll-Barna et al. 2012). 


\subsection{1 Üledékek, talajok}

Az üledékföldtani térkép alapján jól megfigyelheto, hogy a lelőhelyek nagy része a balatoni öblök között húzódó hátak, első sorban pleisztocén kori, barna löszből $\left(e_{-} Q p 3 b l\right)$ és futóhomokból $\left(e_{-} Q p 3-h h\right)$ felépülő térszínein helyezkednek el. Néhány lelőhely található a geológiai értelemben vett tavi-mocsári $\left(I b_{-} Q h\right)$, üledékekkel fedett részeken, de ezek általában a löszös, homokos felületek határa mentén helyezkednek el, valamint a Kis-Balaton természetes, nyílt vízzel borított területéből kiemelkedő szigeteken találhatóak (7.8. ábra).

Megközelítőleg ugyan ez a jelenség figyelhető meg a terület talajtípus szerinti fedvényének kapcsán is. A lelőhelyek nagy része a meridionális hátakon és a hátak lejtőin képződött agyagbemosódásos barna erdőtalajjal, illetve Ramann-féle barna erdőtalajjal fedett részeken helyezkedik el, azonban nagy számban található a lápos réti talajjal, illetve síklápi talajokkal fedett részeken is. Mint az üledéktérkép esetében itt is megfigyelhető, hogy a síklápi és lápos réti talajokkal fedett területeken lévő lelőhelyek a barna erdőtalajjal fedett hátak peremén húzódnak (7.9. ábra).

\subsubsection{Domborzati sajátosságok}

Ezeket a megfigyeléseket egészítette ki a terület domborzati sajátosságaira jellemző lejtésviszonyokat vizsgáló analízis (ArcGIS - ArcMap 10.2 - slope tool). A terület lejtési viszonyait megjelenítő fedvény jól mutatja, hogy lelőhelyek a relatíve alacsony relief ellenére is megfigyelhető módon, általában a dombhátak lejtőinek meredekebb szakaszainak felső peremén, vagy a lejtő felett húzódó vízszintesebb, platószerű részeken helyezkednek el. Ezeken a szakaszokon kívül a lelőhelyek még a meredek domblejtők lábánál, a tómedence és a meridionális hátak határvidékén is megtalálhatóak (7.10. ábra). Ezzel szemben ritkán fordulnak elő megtelepedések a lankásabb, kevésbé meredek domboldalakon. Valószínűsíthető, hogy ezeknek a megfigyeléseknek a hátterében a domboldalak talajvízviszonyai húzódhatnak. A magasabb vízállással rendelkező időszakokban a lankásabb domboldalak talajvízviszonyai olyan értékeket érhettek el, amelyek már befolyással lehettek a megtelepedési viszonyokra, míg az alacsonyabb 

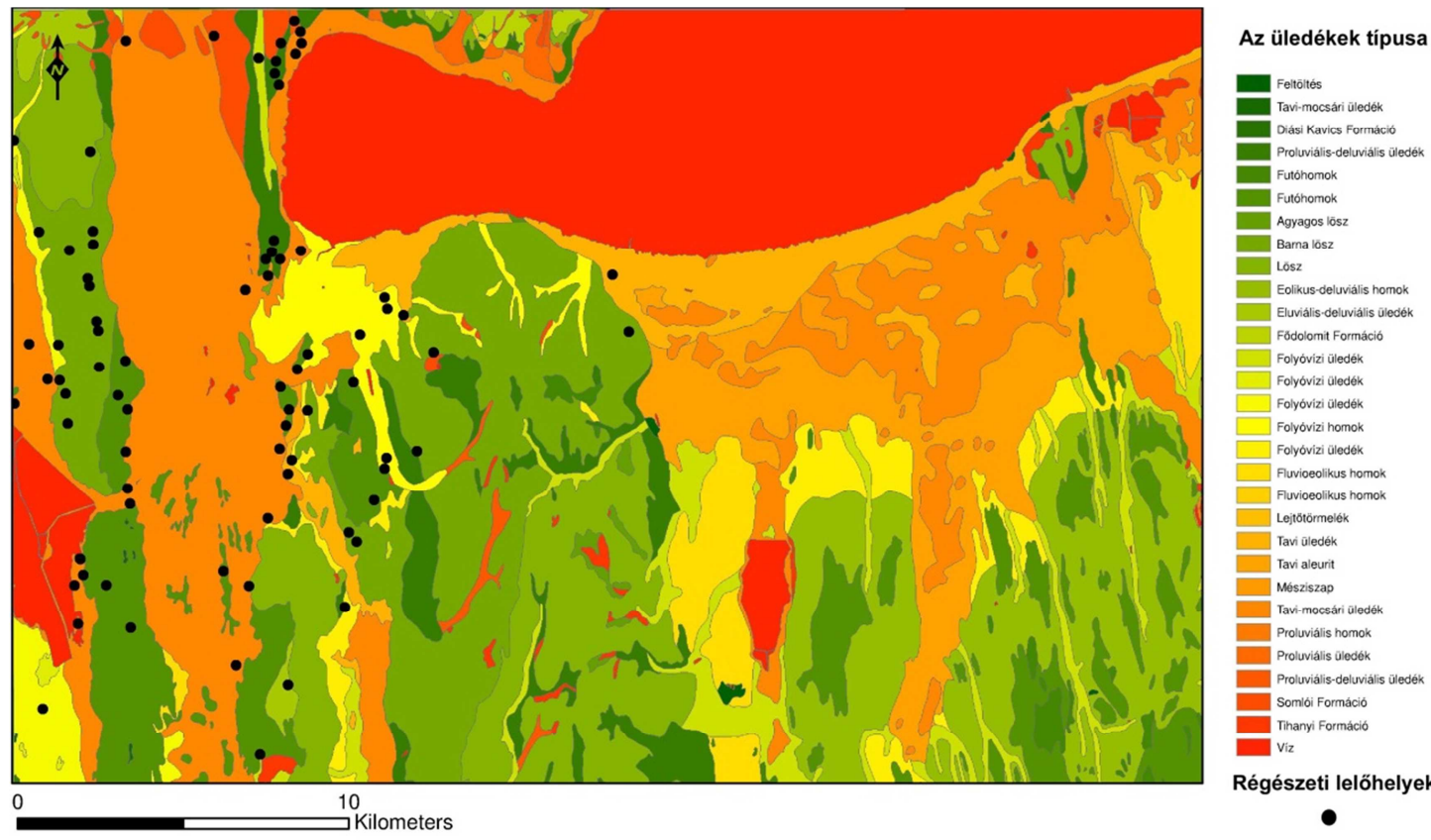

7.8. ábra. A vizsgált terület üledékföldtani térképe a lelőhelyekkel

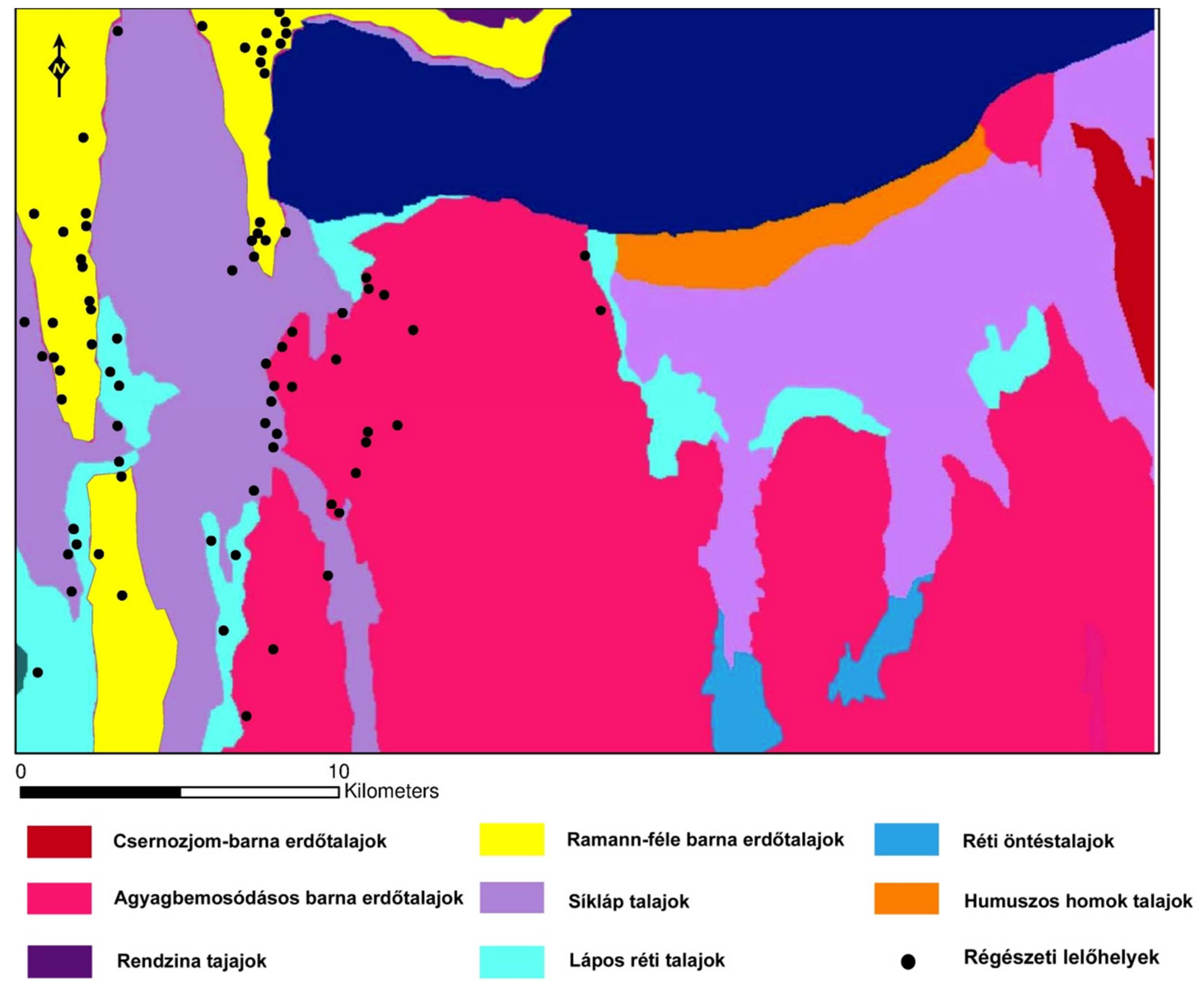

7.9. ábra. A vizsgált terület talajtakaró térképe a lelőhelyekkel 
vízállások esetén még a domblábi régiók is használhatóak lehettek. Ez jól összehangolhatónak tűnik a balatonkeresztúri megfigyelésekkel, ahol a 110-111 méter alatti lejtőt csak néhány, feltételezhetően alacsonyabb vízállású periódusban használták intenzíven.

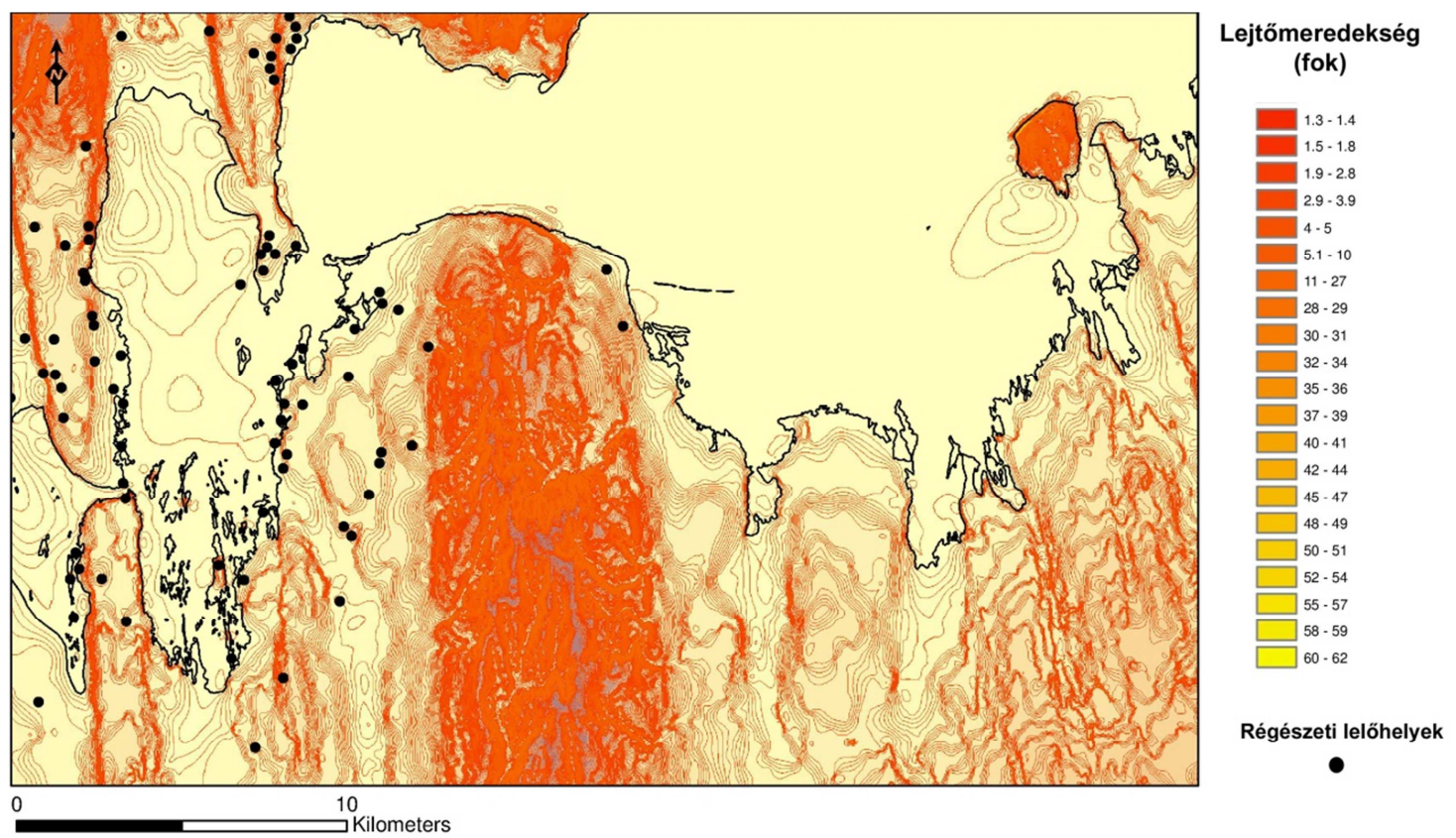

7.10. ábra. A vizsgált terület lejtókitettségi térképe és a 105 mBf vízborítás kiterjedésének határa a lelőhelyekkel

\subsubsection{Felszíni és felszín alatti hidrológia}

A vizsgált terület felszín alatti hidrológiájáról lényegében összefoglalható, hogy a lelőhelyek túlnyomó többsége abban a zónában helyezkedik el, amelyben - legalábbis 1:100.000-es léptékarányban - a talajvíz mélysége a 2-4 méter mélységű intervallumba esik (7.11. ábra). Úgy gondolom, hogy ez a tény tovább erősíti azt a feltevést, hogy a Balaton partvonala mentén az egykori települések abban a zónában jöttek létre, ahol a talajvíz mélysége az évszakos ingadozások által befolyásolt intervallumon belül folyamatosan elérhető volt, és a tó időszakos, hosszabb távú vízingadozásai sem voltak rá szignifikáns hatással. 


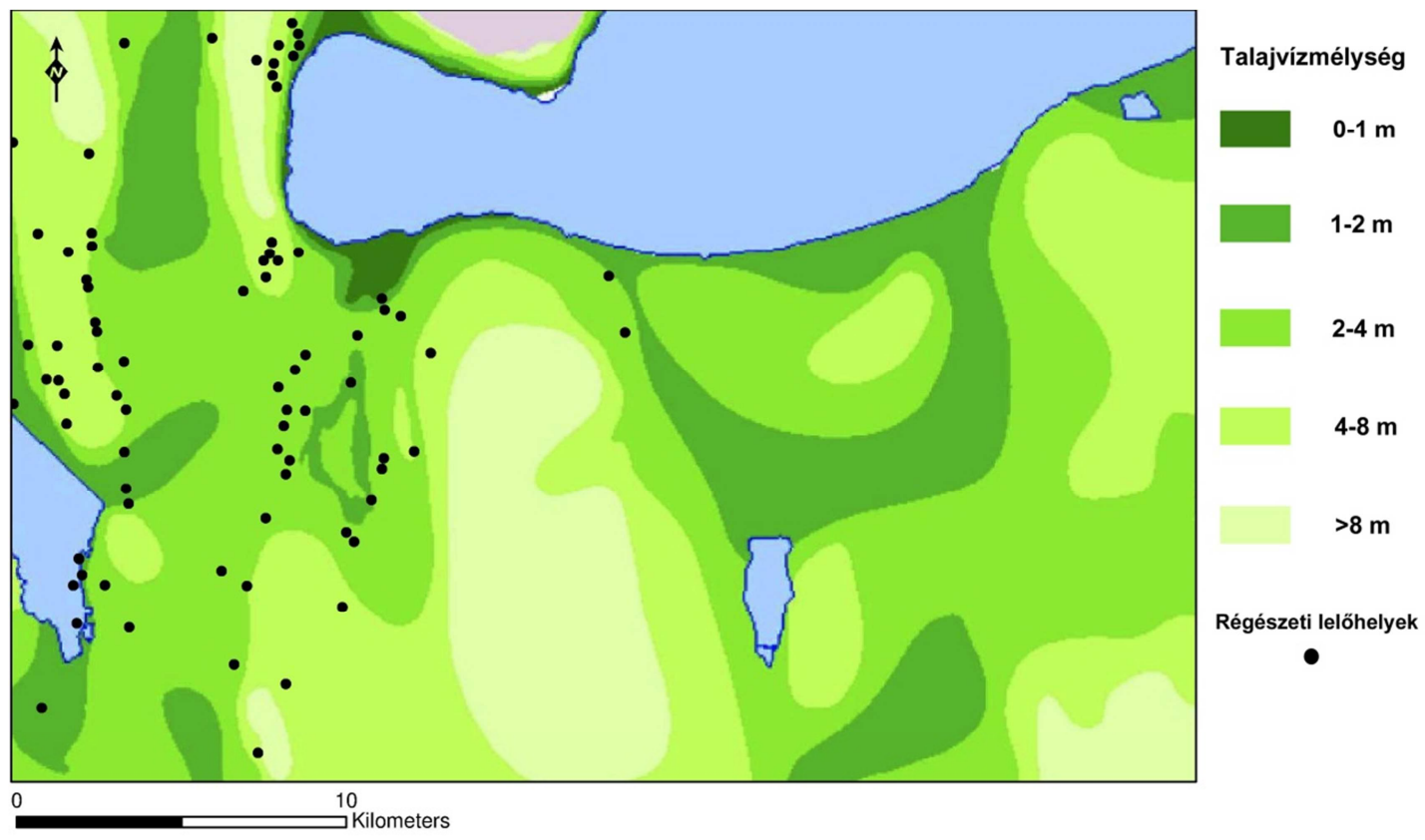

7.11. ábra. A vizsgált terület talajvízmélységét bemutató térképe a lelőhelyekkel

A felszíni hidrológiai viszonyok szempontjából két jelentős elemet kellett figyelembe vennem. Az egyik a tó felületének kiterjedése és a partvonal alakulása a különböző tengerszint feletti vízborítás esetén, valamint a tavat táplálóvízfolyások iránya és lefutása.

A tó vízborítását egy három méteres intervallumban négy különböző értékre határoztam meg (105-108 mBf). A két határérték kijelölésének kettős oka volt (7.2. ábra). Az alsó határ 105 méteres szintben való meghúzása a felhasznált DDM10 digitális domborzatmodell technikai paramétereiből adódott, ugyanis a domborzatmodell ezen a területen 105 mBf magassági szint alatt csak korlátozott információtartalommal bír. A felső érték meghatározásánál az Ordacsehi-Kisöltés lelőhely késő bronzkori árkának kapcsán megállapított késő bronzkor végére, kora vaskor elejére keltezett legmagasabb vízállási adatokra támaszkodtam (Sümegi et al. 410-411; Sümegi et al. 2007, 251-252.), és kiindulva a régészeti adatokból, feltételeztem, hogy az általam vizsgált időszakon belül, a tó természetes állapotában ez volt a legmagasabb vízállás. 


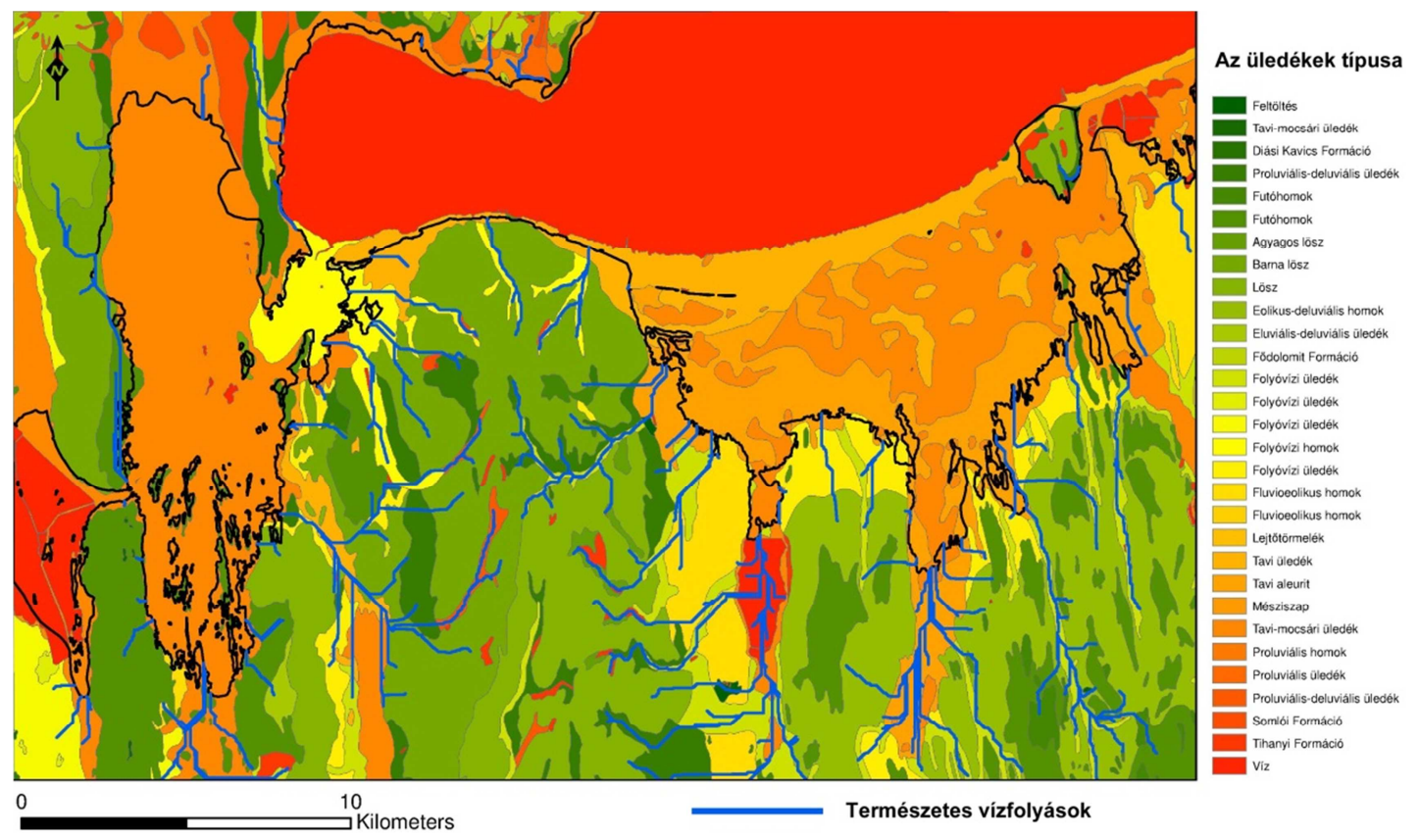

7.12. ábra. A vizsgált terület üledékföldtani térképe a domborzati modell alapján készített természet vízfolyásokkal, 105 mBf vízborítás esetén

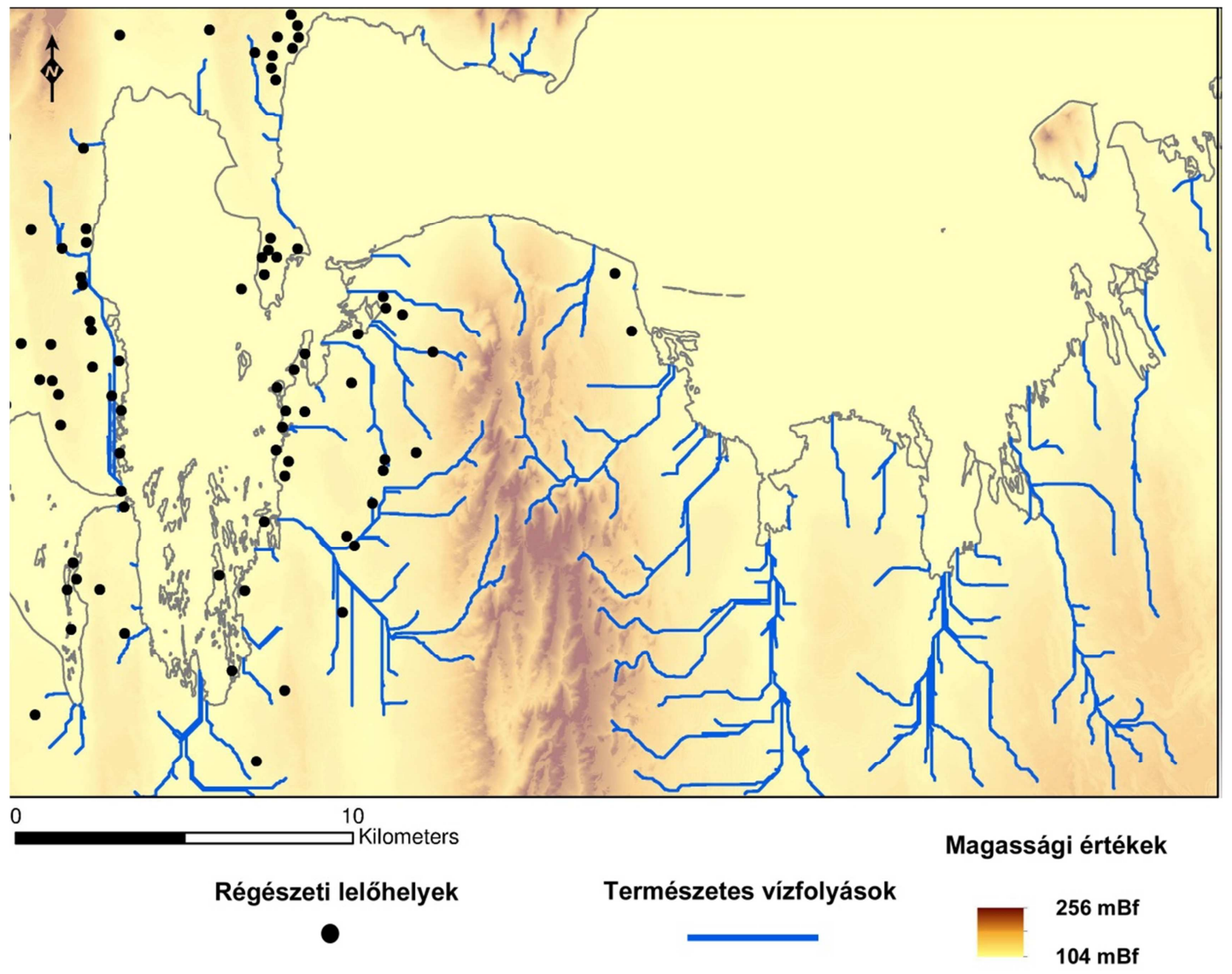

7.13. ábra. A természetes vízfolyások digitális domborzatmodell alapján előállított hálózata a lelőhelyekkel, a tó 105 mBf vízborítása esetén 
A különböző vízszinteknél kialakuló partvonalak, és a lelőhelyeknek a partvonalhoz viszonyított helyzetének vizsgálatakor a terület statikus vízborítási modelljét használtam. A statikus modell a mai, szintvonalas térképekről leolvasható magasságértékkel számol, nem veszi figyelembe a vízborítás megállapításánál a vizsgált időintervallumon belül az emelkedő és süllyedő mozgások mértékét és irányát. Mint hogy ebből a szempontból a Balaton medencéje ma is aktív terület, a teljes tóra vonatkoztatott, abszolút dátumokhoz kötött vízszintek és vízborítás megállapítása esetében a maihoz képest eltérő felszínmagasságok meghatározása elengedhetetlen (Tímár et al. 2010, 455-462.). Mint ahogy azt az ötödik fejezet végén azonban már megjegyeztem, hogy a rendelkezésemre álló adatok csak vízállás tendenciák meghatározására alkalmasak, a különböző régészeti korszakok vízszintjének tengerszint feletti, számszerűsített magasságának megállapítására nem használhatóak, így a statikus modell hibájából származó bizonytalanság elhanyagolható. A statikusmodell használhatósága mellett szól az az érv is, hogy a különböző mértékű süllyedő és emelkedő mozgások tekintetében a nulla érték meghatározása komoly elméleti problémákat okoz, így a vizsgált terület korszakonkénti vertikális elmozdulására alkalmazható abszolút értékủ adatok meghatározása sem egyértelmű (Tímár et al. 2010, 456.). Ezért az nem erősítené tovább a statikus modell jelen pillanatban elérhető megbízhatóságát.

A vízszint emelésével a statikus vízborítási modellben, a vizsgált területre eső tórészlet felülete folyamatosan növekedett (105 méter - 340km²; 106 méter - 374 km²; 107 méter - 408 km²; 108 méter - 427 km²). A mai 104,5 méteres vízmaximumnál fél méterrel magasabb vízállás esetén a mesterséges part menti feltöltések nélkül a tó elönti a Nagyberek területét és a Kis-Balaton keleti medencéjének szinte egészét, valamint a nyugati medence egy részét. További egyméteres vízemelkedéssel tovább növekszik a Kis-Balaton részmedencéinek elöntöttsége, valamint víz alá kerülnek a Nagyberek déli oldalán befutó patakvölgyek torkolatvidékei is. Újabb egy méteres szintemelkedés esetén, 107 méteres vízállásnál, a tó felületének növekedése mellett jelentős vízborítás jelentkezik a Kis-Balatonba és a Nagyberekbe déli irányból torkoló, szabályozott Pogány-völgyi-víz és a Marót-völgyi-csatorna völgyében. A vizsgált 108 méteres maximumértéknél az elemzett területen újabb jelentős részek nem kerülnek 
vízborítás alá, azonban jól látható a kiterjedő vízfelület gyarapodása mind a KisBalaton és a Nagyberek déli partvonala mentén, mind azokon a részeken, ahol az öblök közé nyomuló meridionális hátak lejtői meredekebbek. Ezeken a részeken annak ellenére érzékelhető felületnövekedés mind a négy vízállás esetén, hogy ez a növekedés kevésbé látványos, mint az öblözetek déli partvonalain.

A vízfelület növekedésével a tó partvonala egyre tagoltabb lett, egyre mélyebben benyúló öblözetek és köztük kisebb félszigetek alakulnak ki, amelyek nem egy esetben a vízszint további emelkedésével szigetekké alakulnak.

A Balaton partvonalának és kiterjedésének emberi megtelepedésre gyakorolt hatása mellett a másik hidrológiai tényező a felszíni vízfolyások iránya. A modell elkészítésének és az abba integrált elemeknek az ismertetésénél már részletesen kitértem a felszíni vízfolyások rekonstrukciójára. Az így kapott vízfolyások az interpolált digitális domborzat modellen és nem napjaink valós vízügyi adatain alapulnak, így nem minden esetben feleltethetőek meg napjaink létező patakjaival. Ennek ellenére mégis jól mutatják a hozzáfolyás irányát és helyét a terület természetes állapotában. Ezt jól bizonyítja a modell is, ugyanis, az egymástól függetlenül készült víz akkumulációs modell és a földtani térképmú folyóvízi, proluviális és deluviális üledékviszonyai a területen igen nagy egybeesést mutatnak (7.12. ábra). Ebből adódóan elfogadhatjuk, hogy a terület természetes állapotában ezek a zónák voltak a területre hullott csapadékvíz összegyűlésének fóbb irányai, ezzel állandó, vagy ideiglenes vízfolyásokat kialakítva. A vízfolyások meghatározó szerepét a település helyének kiválasztásában jól mutatja a partvonaltól kicsit távolabb, a Marcali-hát lejtőinek magasabb tengerszint feletti térszínein megtalálható települések elhelyezkedése. Ezek a lelőhelyek zömmel az M7 autópálya nyomvonalának megelőző munkálatainak során kerültek feltárásra, és jól láthatóan, kivétel nélkül olyan völgyekben helyezkednek el, amelyekben a vízfolyás akkumulációs algoritmus a beállított értékek és a domborzati sajátosságok alapján vízfolyást határozott meg (7.13. ábra). 


\subsection{A Kis-Balaton szigetei}

A vízkitöltési modell előállításakor külön figyelmet kellett szentelnem a Kis-Balatonban lévő számos, kisebb-nagyobb szigetnek. A lelőhelyeknek egy nagy része ugyanis ezeken a szigeteken helyezkedik el.

Az 1:50.000 méretarányú térképen alapuló DDM10-es digitális domborzatmodell 5 méteres vertikális felbontása miatt a négy vízborítási érték újraosztályozott raszteres és az abból előállított vektoros állomány lefedte legtöbb sziget 105 és 110 méter közötti legmagasabb szintértékeit. A Kis-Balatonban lévő szigetek nagy többsége éppen ebbe a tengerszint feletti magassági tartományba tartozik. A szigetek területét külön kellett kivágni a vízborítás poligonjaiból.

A szigetek magasságának jelentősége, a modellkészítés technikai részletei mellett abban rejlik, hogy a különböző vízállási értékek esetén miként változik a szigetek területe és a vízszint feletti magassága, amely jelentősen befolyásolja a megtelepedés lehetőségeit. A vizsgálat során a szigetek számába a két legnagyobb szigetet Fonyód-Várhegyet és az északi parton lévő, de a vízborítási modellben megjelenő Vonyarcvashegy, Szent Mihály-dombot nem vettem bele.

A szigetek számának alakulásában érdekes jelenséget figyelhetünk meg, ugyanis a 105 méteres vízborítás esetén kialakuló 151 kisebb-nagyobb sziget egy méteres vízállás emelkedés esetén 106 méteres vízborításnál jelentős számbeli növekedést mutat. Ennek kettős oka van, részben az újonnan elöntött területeken számos új sziget keletkezik, másrészt a korábbi, nagyobb kiterjedésű szigeteken a kiemelkedések közötti, 105 méteres magasságú részek víz alá kerülnek. Így a korábbi nagyterületű szigetek több, kisebb szigetté „esnek szét”. A szigetek száma 189-re emelkedik, annak ellenére, hogy néhány korábbi szigetet az emelkedés során elönt a tó vize.

Újabb egy méteres vízszintemelkedés esetén 107 méteres vízállásnál a szigetek száma már csökkenő tendenciát mutat, száma közel azonos a 105 méteres vízálláséval, 149 darab. Ebben az esetben már jóval kevesebb új sziget keletkezik a 107 méteres vízszint esetén újonnan elöntött területeken, mint egy méterrel alacsonyabb vízszintnél. A szigetek „darabolódása” folytatódik, és több kisebb korábbi szigetet teljesen elönt a tó vize. 


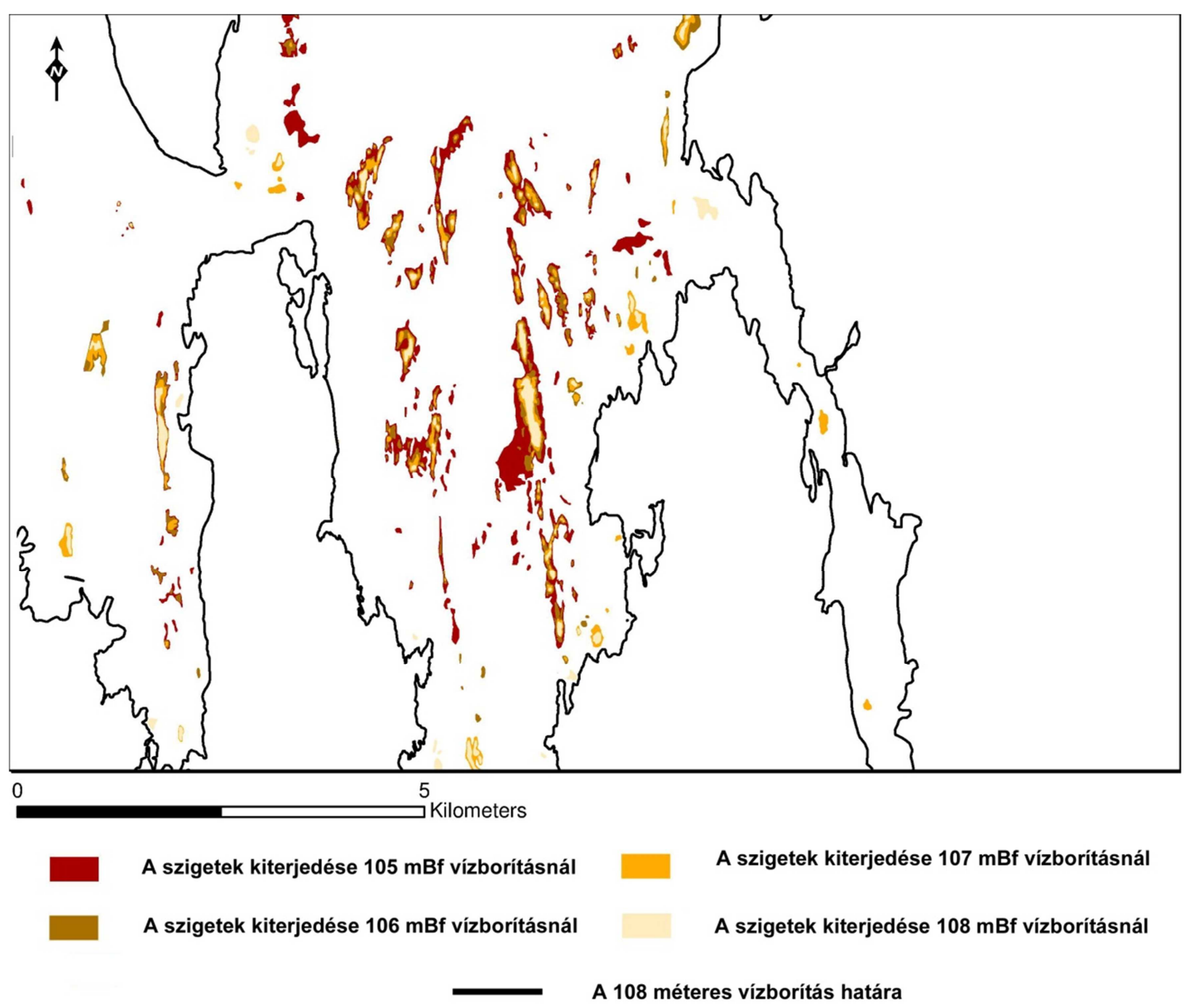

7.14. ábra. A kis-balatoni szigetek kiterjedésének változása a négy vízborítási érték esetén

Abban az esetben, ha a vízszintet a vízkitöltési modell maximumértékéig emeljük, akkor azt vehetjük észre, hogy a szigetek száma tovább csökken 99 darabra. Új szigetek alig keletkeznek, ellenben számos olyan szigetet elönt a víz, amelyek 107 méternél még, ha csekély mértékben is, de a vízfelszín fölé magasodtak.

Jóval egyértelműbb összefüggések figyelhetők meg a vízállás emelkedése, és a szigetek összterületének csökkenése között. A csökkenés mértéke folyamatos, egyetlen vízállás esetén sem figyelhető meg területnövekedés (105 méter - 8,7 km²; 106 méter - 7,9 km²; 107 méter - 2,9 km²; 108 méter -1,6 km²). A legjelentősebb változás a 106 és 107 méteres vízszintek közötti váltás esetén figyelhető meg, amikor a szigetek összterülete kevesebb, mint a felére csökken. A legkisebb csökkenést 105 és 106 méter közötti vízállásváltozásnál figyelhetünk 
meg, amelyet indokol a szigetek számának növekedése. Ezzel szemben 107 méteres vízállásnál a szigetek száma megközelítőleg ugyan annyi, mint 105 méteres szint esetén. Miközben a szigetek összterülete több mint 60 százalékkal csökken a 105 méteres szinthez tartozó értékhez viszonyítva (7.14. ábra).

A szigetek magassága rendkívül alacsony, amelyet már a digitális domborzatmodell 5 méteres vertikális felbontásából adódó korrekciók szükségessége is jól mutatott. Mindössze 15 sziget tengerszint feletti magassága éri el a 110 métert, a legmagasabb pont Sávoly-Fekete-szigeten van, ami 112,3 méter. A vízből leginkább kiemelkedő 15 sziget közül mindössze 4 esetében rendelkezünk adatokkal régészeti lelőhelyekről, Sávoly-Fekete-sziget, Balatonmagyaród-Kányavári-sziget, Sávoly-Nyírfás-sziget és Vörs-Papkert B. Az utolsóként említett lelőhely csak 106 méteres vízállás esetén válik szigetté.

A vizsgált terület szigeteiről összességében elmondható, hogy domborzati szempontból rendkívül alacsonyak, területük a vízállás emelkedésével rohamosan csökken, ezért érzékenyen reagálnak a tó vízállásváltozására. Ez pedig rendkívül jelentősen befolyásolja az emberi megtelepedési viszonyokat. Hozzátehetjük még ehhez, hogy a megtelepedés feltételeit nem csak a nyílt víztükör szintje befolyásolja, hanem a talajvízhatás, valamint a Balaton hullámzása is. Ebből adódóan a szigetek nem csak abban az estben válnak lakhatatlanná, amikor elborítja őket a Balaton vize, hanem a csúcsmagasságuknál legalább egy méterrel alacsonyabb vízállásnál is előáll ez a helyzet.

Még egyszer vissza kell térnem röviden a tektonikai tényezőre. Mint azt már korábban említettem, a statikus vízborítási modell nem számol a tektonikai tényezőkkel. Ebből adódóan a különböző régészeti korszakokban a szigetek abszolút magassága és a mindenkori vízszint tengerszint feletti magassága nem feltétlenül egyezik meg a mai szintmagasságokon alapuló vízkitöltési modell abszolút értékeivel. Ezért az elemzések során használt 105-108 méteres tengerszint feletti magasságok nem a korszak tényleges vízszintjét, hanem a tendenciák egyértelmű megítéléséhez szükséges, a vizsgált három méteres intervallumon belüli határértékeket jelölik. 


\section{A statikus vízkitöltési modell és a régészeti lelőhelyek geomorfológiai helyzete közötti összefüggések elemzése}

\subsection{A lelőhelyek}

A régészeti lelőhelyek elhelyezkedésének a területre vonatkoztatott, általános szabályszerűségeinek vizsgálatát követően igyekeztem felmérni a korszakokra vonatkoztatható szabályszerűségeket a négy vízállás függvényében. Ennek célja, hogy a lelőhelyek elhelyezkedésére vonatkozó általános meghatározó tényezőkön belül felfedezhetőek-e környezeti okra visszavezethető, vagy azzal nem indokolható változások. Ezek segíthetnek felfedezni a kisebb amplitúdójú változásokat, a Balaton hosszú távú változási mechanizmusán belül.

A tó állapotába történő, első antropogén eredetű beavatkozás időhatárán belül a balatonkeresztúri lelőhelyen megtalálható régészeti kultúrákkal azonos korú megtelepedések geomorfológiai helyzetét is vizsgáltam. A régészeti szakirodalom és a publikációk térképi állományára támaszkodva, a minél szélesebb, vizsgálható mintasor érdekében azonban elkészítettem a neolitikus Vonaldíszes Kerámia kultúrájának (Bánffy et al. 1996, 28-29; Honti et al. 2007, 770.), a neolitikus és kora rézkori lengyeli kultúrának (Bánffy et al. 1996, 28-29.), a középső rézkori Balaton-Lasinja kultúrának (Bánffy et al. 1996, 30-31; Honti et al. 2007, 7-70.), a késő rézkori Badeni kultúrának (Bánffy et al. 1996, 38-40; Honti et al. 2007, 7-70.), a kora bronzkori Somogyvár-Vinkovci és Kisapostagi kultúráknak (Bondár et al. 1996, 53-55; Honti et al. 2007, 7-70.), a középső bronzkori Mészbetétes Kerámia kultúrájának (Bondár et al. 1996, 53-55; Honti et al. 2007, 7-70.), a késő bronzkori Urnamezős kultúra (Bondár et al. 1996, 72-73; Honti et al. 2007, 7-70.), és a késő vaskori La Téne C-D időszak (Horváth et al. 1996, 8182; Honti et al. 2007, 7-70.) és a kora császárkori (Horváth et al. 1996, 88-91; Honti et al. 2007, 7-70.) lelőhelyeinek pontállományát ${ }^{16}$. A lelőhelyek részletes listáját a dolgozat 3. melléklete tartalmazza.

A késő bronzkorra (Urnamezős kultúra) vonatkozó lelőhelyek vizsgálatát a korszak objektumainak a balatonkeresztúri lelőhelyen tapasztalt teljes hiánya, és az ordacsehi lelőhelyen megfigyelt magas korabeli vízállás indokolta, a

\footnotetext{
${ }^{16}$ A pontállománnyal kapcsolatos problematika kifejtését lásd a dolgozat 7.3 fejezetrészében.
} 
feltételezett összefüggés indoklása szempontjából a több lelőhely geomorfológiai adataiból levonható következtetések érdekesek lehetnek.

\subsection{A neolitikum időszaka}

A neolitikum időszakából a vizsgált területen két korszak megtelepedéseit ismerjük. A középső neolitikum időszakára keltezhető Vonaldíszes Kerámia kultúráját és a késő neolitikumra, valamint részben a kora rézkorra keltezhető Lengyeli kultúra településeit. A két időszak településeit, valamint azokat a lelőhelyeket, amelyeken mind a két időszak megtelepedéseinek nyomai előfordulnak, külön választva elemeztem.

\subsubsection{A Vonaldíszes Kerámia kultúrájának időszaka}

A középső neolitikum időszakára keltezhető időszak településjelenségei a 105 méteres vízállás esetén minden tekintetben kiegyensúlyozott képet mutattak. A telepek a tó partvonala mentén a meredekebb lejtők peremén és a meridionális hátak vízszintes platóin, valamint néhány esetben a Kis-Balaton szigetein helyezkedtek el (8.1. ábra).

Egy méterrel magasabb vízszint, 106 méteres vízállás esetén a lelőhelyek nagy részét a meredek lejtők miatt továbbra sem fenyegette a tó vize általi elöntés, kivéve a feltárások bizonyítékai alapján rendkívül alacsonyan fekvő ZalavárBalatonhídvég lelőhelyet, (M. Virág 1986a, 271; Bánffy et al. 1996, 30. 72. lh.), amely ebben az esetben közel került a partvonalhoz. A kis-balatoni szigetvilágban lévő, Sávoly-Fekete-sziget (Honti 1986a, 265.17; Bánffy et al. 1996, 29. 154. lh.) területe jelentősen leszűkült (8.1. ábra).

Amennyiben a vízszintet további egy méterrel 107 méter magasságúra növeltem, abban az esetben a Zalavár-balatonhídvégi lelőhelyet már csak kisebb, vízből alig kilógó kiemelkedések jelentik, míg Sávoly-Hupolagos (Honti et al. 2007, 18-19.) lelőhely, amely az előző két esetben a Kis-Balaton felé lejtő, vízfolyással rendelkező völgyben feküdt, a völgy elárasztásával vízpart közeli településsé vált.

${ }^{17}$ A publikációban a lelőhely Főnyed-Feketesziget néven szerepel. 
A szigetek területe tovább szúkül, Sávoly-Fekete-sziget területe már alig látszott ki a vízből, megtelepedésre alkalmatlanná vált (8.2. ábra).

A vizsgálat szempontjából legmagasabb 108 méteres érték esetén a meredekebb lejtőszakaszok peremén létesült part közeli települések továbbra is nagy biztonságban vannak a közvetlen elöntéssel szemben. Sokkal inkább veszélybe kerülnek a kis-balatoni szigetvilág települései. A szigeteket BalatonmagyaródKányavári-sziget (Bánffy et al. 1996, 29. 114. lh.) kivételével teljesen elönti a Balaton vize (8.2 ábra).

Összefoglalásul azt állapíthatjuk meg, hogy a középső neolitikum időszakában a települések nagy része még magas vízállás esetén is biztonságos helyen van. A Zalavár-Balatonhídvég lelőhely, valamint a szigeteken lévő lelőhelyek adatai szerint az időszakban számolnunk kell egy alacsonyabb vízállású periódussal is, amikor ezekeknek a lelőhelyeknek a területe megtelepedésre alkalmasak voltak. Ebben az esetben vagy a Balaton vízállásának időszakon belüli nagyobb méretű változását kell valószínűsítenem vagy a megtelepedés helyszínét meghatározó elemként a Balaton vízállása mellett, több más tényezőt is figyelembe kell venni.

\subsubsection{A Lengyeli kultúra időszaka}

A késő neolitikum és a korai rézkor időszakára keltezhető Lengyeli kultúra kisszámú lelőhelye a Balaton partvonalától nagyobb távolságban magasabb térszíneken helyezkedik el. Ki kell azonban emelnem Vörs-Kerékerdő (Bánffy et al. 1996, 29. 141. lh.), valamint a Kis-Balatonban keleti medencéjében lévő Balatonmagyaród-Szarkavári-sziget (Bánffy et al. 1996, 29. 116. lh.) lelőhelyeket. Vörs-Kerékerdő lelőhely Vörs községtől északnyugatra a Kis-Balatonba benyúló félszigeten fekszik. A Balatonmagyaród-Szarkavári-sziget lelőhely körül a sziget kiterjedése már 105 méteres vízállás esetén is rendkívül kicsi (8.3. ábra).

Egy méteres vízszintemelkedés esetén, 106 méteres vízszintnél Vörs-Kerékerdő lelőhely környékén a félsziget területe jelentősen csökken, valamint a Balatonmagyaród-Szarkavári-sziget kiterjedése is nagymértékben zsugorodik. Vörs-Battyáni-disznólegelő lelőhely (Honti 1986b, 271; Bánffy et al. 1996, 29. 
138. lh.) pedig egy szűk, három oldalról a Balaton által körülvett félszigetté szűkül (8.3. ábra).

Az ismételt egy méteres vízszint emelkedés esetén, 107 méteres vízborításnál a Vörs-Kerékerdő lelőhely már csaknem egy szigeten helyezkedik el, Balatonmagyaród-Szarkavári-sziget területét teljes mértékben elönti a tó. Vörs Battyáni-disznólegelő lelőhelyet körülveszi a tó, területe egy mindössze 3 hektár kiterjedésű szigetté megy össze (8.4. ábra).

Újabb 1 méteres, 108 méteres szintet elérő vízszintemelkedés esetén VörsKerékerdő lelőhely egy kiskiterjedésű szigetre szorul, valamint az eddig a partvonaltól viszonylagos távolságban lévő Keszthely-Halászrét (Bánffy et al. 1996, 28. 35. lh.) lelőhely közetlen közelébe ér a Balaton nyílt víztükre. VörsBattyáni-disznólegelő egy a Balatonból alig kiemelkedő, kisméretű, megtelepedésre alkalmatlan szigetté zsugorodik (8.4. ábra).

A felsorolt tendenciák alapján a késő neolitikum és a kora rézkor időszakára a neolitikum korábbi időszakánál magasabb vízállást feltételezhetünk, a települések a partvonaltól távolabb helyezkednek el. A Szarkavári-szigeten lévő lelőhely magassági adatai szerint azonban 106 méteres szintnél a sziget legmagasabb pontja épphogy kiemelkedik a vízből, területe kicsire zsugorodik, ebben a szakaszban a sziget tartós megtelepedésre már nagy valószínúséggel nem alkalmas

\subsubsection{A több korszakú neolitikus lelőhelyek}

A vizsgálat alá vont területen összesen négy olyan lelőhelyet (Balatonmagyaród-Hídvégpuszta (Szőke-Vándor 1987, 85-86; Bánffy et al. 1996, 29. 113. lh.), Sávoly-Bákos-domb (Honti et al. 2007, 19.), Vörs-Máriaasszonysziget (Bánffy et al. 1996, 29. 140. lh.), Zalavár-Ökörsziget (Bánffy et al. 1996, 29. 76. lh.)) ismerünk, ahol egyaránt megtalálhatóak a középső neolitikumra keltezhető Vonaldíszes Kerámia kultúrájának és a későbbi Lengyeli kultúrának a településobjektumai. Ebből két eshetőség adódik, egyrészt, hogy a lelőhelyek minden szempontból megfeleltek egy hosszabb távú, korszakokon átnyúló megtelepedésre, vagy pedig a terület több fázisban időszakonként volt lakott. 
A felsorolt lelőhelyek közül a sávolyi az M7 autópálya nyomvonalában, a partvonaltól messze a meridionális dombhát nyugati lejtőjén került elő. A másik három lelőhely 105 méteres vízszint esetén nem messze a partvonaltól helyezkedik el, azonban a lelőhelyek elnevezéséből következően (Máriaasszonysziget, Ökör-sziget) magasabb vízállások esetén már a Kis-Balaton szigetvilágának részeivé válnak (8.5. ábra).

Ezt jól mutatja, a 106 méteres vízborítási modell, ekkor ugyanis Zalavár-Ökörsziget a valóságban is sziget lesz, míg Vörs-Máriaasszony-sziget még ugyan félsziget, de csak egy keskeny földnyelv köti össze a magasabban fekvő part menti részekkel (8.5. ábra).

Újabb egy méteres vízszintemelés esetén, 107 méternél Vörs-Máriaasszony-sziget ténylegesen szigetté válik, Zalvár-Ökör-sziget területe tovább zsugorodik (8.6. ábra).

Zalavár-Ökör-sziget lelőhelyet újabb 1 méteres vízemelkedés, 108 méteres vízállás esetén elönti a tó, Vörs-Máriasszony-sziget még ugyan kint van a vízből, de a szintvonalas térkép adatai szerint egy mindössze 2 hektár kiterjedésű és fél méterrel a vízszint fölé magasodó szigetté válik. Ilyen körülmények között elképzelhetetlen a huzamosabb ideig tartó megtelepedés a szigeten (8.6. ábra).

A neolitikum és a kora rézkor időszakára keltezhető, közvetlenül a partvonal mentén, illetve a szigeteken lévő települések geomorfológiai helyzete és a vízborítási modell összefüggései alapján a tárgyalt időszakra valószínűsíthető egy vagy több kisebb intervallumú vízingadozás. A modell tapasztalatai alapján azonban a 108 méteres szint elérése nem állapítható meg biztosan, mert az esetek túlnyomó többségében a part menti telepeket és a szigeteket már jóval korábban elönti a víz, vagy olyan csekély kiemelkedés alakul ki, amely megtelepedésre alkalmatlanná teszi őket. Ezzel szemben olyan szigeteken, amelyeknek legmagasabb kiemelkedése 110-112 méter, nem ismerünk a korszakhoz tartozó megtelepedéseket. Ebből következően, a középső és késő neolitikum időszakára feltételezhetünk ugyan időleges vízingadozásokat, azonban azok nagy valószínűséggel az esetek túlnyomó többségében megmaradnak a 105-107 méter közötti 2 méteres intervallumon belül. A domboldalak lejtőinek felsőbb régióiban és a 110-120 méteres tengerszint feletti magasságú vízszintes platókon azonosított lelőhelyek esetében, a terület 
talajvízviszonyainak ismerete nélkül nem állapítható meg összefüggés a megtelepedések helye és a tó vízállásváltozásai közötti összefüggések.

\subsection{A középső rézkor időszaka}

A középső rézkor időszakára keltezhető lelőhelyekről általánosságban elmondható, hogy a vizsgált terület magasabb térszínein a vízállásváltozás által közvetlenül nem befolyásolt részeken helyezkednek el (8.7. ábra). Kisszámú kivétel azonban itt is tapasztalható. Néhány lelőhely (Balatonmagyaród-Pörköltsziget (Bánffy et al. 1996, 31. 120. lh.), Balatonmagyaród-Szarkavári-sziget (Bánffy et al. 1996, 31. 116. lh.), Zalavár-Basa-sziget (Bánffy et al. 1996, 30. 77. lh.)) a Kis-Balaton szigetein található, illetve néhány középső rézkori megtelepedés a már 105 méteres vízállás esetén is a partvonal közvetlen közelébe esik (Sávoly-Demjén-telep (Bánffy et al. 1996, 31. 126. lh.), Vörs-Kanászkert (Bánffy et al. 1996, 31. 153. lh.), Vörs-Nyíres-sziget (Bánffy et al. 1996, 31. 152. lh.), Vörs-Papkert B (Bánffy et al. 1996, 31. 143. lh.), Zalavár-Balatonhídvég (M. Virág 1986, 271; Báffy et al. 1996, 30. 72. lh.), Zalavár-Hídvégi-legelő (Bánffy et al. 1996, 31. 81. lh.), Zalavár-Kövecses (Bánffy et al. 1996, 31. 80. lh)).

Egy vízszintemelkedés esetén 106 méteres vízborítás kialakulásakor a szigetek területe jelentősen lecsökken (főleg a Balatonmagyaród-Szarkavári-sziget és a Vörs-Nyíres-sziget területe), valamint Vörs-Papkert B lelőhely kiemelkedését is körbeveszi a Balaton. Ennek a vízállásnak az esetében, Zalavár-Hídvégi-legelő, Zalavár-Kövecses lelőhelyeket elfedi a tó vize, míg Sávoly-Demjén-telep közvetlen vízparti teleppé válik (8.7. ábra).

A következő, 107 méteres vízállás esetén a Balatonmagyaród-Pörkölt-sziget kivételével az összes szigetet elönti a víz, és nagyrészt víz alá kerül a ZalavárBalatonhídvég lelőhely is. Vörs-Kanász-kert egy, a Kis-Balatonba benyúló keskeny félszigeten helyezkedik el a 107 méteres vízállás esetén (8.8. ábra).

A vizsgált legmagasabb, 108 méteres vízállás során a 107 méteres szinthez viszonyítva a megfigyelhető állapotok nem sokat változnak, egyedül a Balatonmagyaród-Pörkölt-sziget területe szűkül olyan kicsire, hogy emberi megtelepedésre alkalmatlanná válik (8.8. ábra). 
A középső rézkori part menti és szigeteken elhelyezkedő telepek tengerszint feletti magasságértéke és a vízborítási modell adatainak összefüggése alapján a középső rézkor időszakára jelentősebb vízállás emelkedést nem valószínűsíthetek, mert azok a szigetek, amelyeken a korszakhoz köthető megtelepedések nyomai ismertek, már csekély vízemelkedés esetén is lakhatatlanná váltak csakúgy, mint a part menti telepek. A magasabb térszíneken, a dombhátak platóin lévő telepek esetében a megtelepedés helyének kiválasztásában más tényezők játszhattak szerepet. A megfigyelést a balatonkeresztúri lelőhely jelenségei is megerősítik, ahol a lelőhelyen belül a legmagasabb térszínen helyezkedtek el a korszak objektumai, azonban az időszakhoz köthető kút feltárási adatai alacsony talajvízszintet feltételeztek.

\subsection{A késő rézkor időszaka}

A késő rézkor időszakának települései jól látható módon, néhány kivételtől eltekintve a tó partvonalának közelében és a part menti domblejtők magasabb részein helyezkedtek el. A kivételek az M7 autópálya Marcali-háttól nyugatra futó nyomvonalába eső települések (Sávoly-Bákos-domb, (Honti et al. 2007, 19.) Szőkedencs-Cölömpös-árok (Honti et al. 2007, 20-22.), Tikos-Bari-dűlő (Honti et al. 2007, 15.), Tikos-Homokgödrök (Honti et al. 2007, 16-18.) és Tikos-Nyárfásdűlő (Honti et al. 2007, 15-16.)). Ezeknek a lelőhelyeknek a geomorfológiai elhelyezkedése és a vízállási viszonyok változása közötti közvetlen kapcsolata a talajvízviszonyok rekonstrukciójának hiányában nem lehetséges.

A vízállás viszonyok rekonstrukciójának kapcsán rendkívül szemléletes a Keszthely-Hévizi-öböl (MRT1 1966, 78. 21/15. lh; Bánffy et al. 1996, 39. 18. lh.) lelőhely elhelyezkedése, amely már az alacsonynak mondható 105 méteres vízállás esetén is a partvonaltól messze, a modellben vízzel borított területen helyezkedik el. A Keszthely-Hévizi-öbölben előkerült, korszakra jellemző leletanyag azonban mindössze néhány bögre és agyagnehezék volt, amely csatornaásáskor vastag tőzegtakaró alól került elő. A tőzegréteg bizonyíthatja, hogy a későbbi időszakokban magasabb vízállások esetén váltakozó nyíltvízi és mocsári állapotok voltak a területen. A lelőhely kiterjedésére, az esetleges rézkori 
telephez tartozó objektumokra azonban nincsen adat, így ezeknek a hiánya miatt a jelen vizsgálat szempontjából a lelőhely nehezen értékelhető.

A Kis-Balaton szigetein csak Balatomagyaród_Kányavári-szigeten valószínűsíthetünk késő rézkori telepjelenségeket (Bánffy et al. 1996, 38. 114. lh). Ez a sziget a Kis-Balatonból az egyik leginkább kiemelkedő szárazföldi rész (8.9. ábra).

A vízszint emelésével, 106 méteres vízállásnál víz alá kerül a BalatonszentgyörgyFelüljáró (Bánffy et al. 1996, 39. 172. lh) lelőhely, valamint FonyódBézsenypuszta (Honti et al. 2007, 35-38.) lelőhely közvetlen közelébe kerül a Balaton partvonala (8.9. ábra).

Újabb egy méteres vízállás emelkedés, 107 méteres vízszint esetén a Balaton körülveszi a Balatonszentgyörgy-Vasútállomás (Bánffy et al. 1996, 39. 136. lh.) lelőhelyet, a kialakuló sziget alig egy méterrel emelkedik a víz fölé. Ennél a vízállásnál a tó vize elönti a Balaton nyugati végén lévő Keszthely-Honvéd utca lelőhely területét is (Bánffy et al. 1996, 39. 10. lh) (8.10. ábra).

A vizsgált vízállások 108 méteres maximumának esetében a szigeteken, jelentősen leszűkült területük és a vízből való alacsony kiemelkedésük miatt nem valószínűsíthető jelentősebb megtelepedést (8.10. ábra).

A balatoni öblök között húzódó meridionális hátak lejtőin lévő településeket a vízállás emelkedés közvetlenül egyáltalán nem befolyásolta, a területek talajvíz viszonyairól nem rendelkezünk adatokkal, így a közvetett hatását nem tudom megítélni.

A kis-balatoni program keretében előkerült és a topográfiai gyűjtések során azonosított késő rézkori lelőhelyek nagy számuk ellenére sem kiterjedésben sem belső kronológiai változatosságukban nem mérhetőek az autópálya nyomvonalában feltárt több hektáros településrészek régészeti adatmennyiségéhez. Így sok esetben nem dönthető el, hogy a badeni kultúra időszakán belül a területen több fázis megtelepedései is megtalálhatóak-e. Az autópálya megelőző feltárásainak lelőhelyei azonban jól mutatják, hogy általában a telepek több fázisúak, a bolerázi időszakra jellemző leletanyaggal azonosítható a megtelepedés korai fázisa (Tikos-Homokgödrök) de több esetben a telepek klasszikus baden időszakában is léteznek (Balatonkeresztúr-Réti-dűlő, TikosBari-dűlő). Néhány esetben a késő rézkori megtelepedés egészen korai 
időpontban, a protobolerázi horizont időszakában kezdődik (Sávoly-Bákos-domb, (Honti et al 2007, 19.) Tikos-Nyárfás-dűlő (Honti et al. 5007, 15-16.)).

Feltételezhető, hogy ez a differenciáltság jellemző a többi, kisebb lelőhelyre is (Balatonmagyaród-Hídvégpuszta (Bánffy et al. 1996, 38. 113. lh.), Balatonmagyaród-Kiskányavár (Horváth 1984, 257; Bondár 1985, 268; Horváth 1986, 264; Bondár 1991, 137-154; Bánffy et al. 1996, 38. 115. lh.), KeszthelyVámház (MRT1 1966, 81. 26.lh; 30. lh; Bánffy et al. 1996, 39. 20. lh..), SármellékÉgenföld (M. Virág 1986b, 269; Bánffy et al. 1996, 40. 65. lh; M. Virág 1999, 3354.)). A balatonkeresztúri lelőhely településszerkezeti megfigyelései, valamint a részletesen feldolgozott leletanyag relatív és abszolút kronológiai fázisai alapján elvégzett stabilizotópos geokémiai vizsgálatok azt mutatták, hogy az időszak alatt feltételeznünk kell egy kulturális szempontból jelentős hatású klimatikus ingadozást (Serlegi et el. 2012; Schöll-Barna et al. 2012). Ez az éghajlati esemény minden bizonnyal befolyással volt a tó vízállására is, ami azonban az autópálya több fázisú lelőhelyeinek tanúsága szerint a korszak településeinek helyére nem volt hatással. Valószínűnek tartom, hogy a többi, domboldali település esetében is ugyan ezzel a jelenséggel állunk szemben, erre azonban biztos választ csak hasonló részletességű kronológiai és településszerkezeti megfigyelések birtokában adhatunk.

A késő rézkori megtelepedések geomorfológiai elhelyezkedése és a vízborítási modell összefüggéseiből a következtetések csak a balatonkeresztúri megfigyelésekkel kiegészítve vonhatóak le. Ezek azonban jól kiegészítik egymást abban a tekintetben, hogy a bizonyítható éghajlati ingadozások ellenére a Balaton vízállásában nem következett be olyan lényeges változás, ami érdemben befolyásolta volna a megtelepedések helyét a késő rézkor időszaka alatt.

\subsection{A kora bronzkor időszaka}

A kora bronzkor időszakát a vizsgált területen két kultúra megtelepedési periódusára osztja a kutatás, a Somogyvár-Vinkovci és a Kisapostagi kultúrák korszakaira. A két időszak településeit, valamint azokat a lelőhelyeket, amelyeken mind a két időszak megtelepedéseinek nyomai előfordulnak, külön választva elemzem. 


\subsubsection{A Somogyvár-Vinkovci kultúra időszaka}

A korai bronzkornak a Somogyvár-Vinkovci kultúra időszakával jellemezhető szakaszából viszonylag kisszámú lelőhellyel rendelkezünk. A lelőhelyek elhelyezkedése ezen belül azonban változatos képet nyújt. A lelőhelyek egy része az alacsony vízállású partvonalaktól viszonylag távol (SzegerdőLegelői-dűlő (Bondár et al. 1996, 54. 192. lh.), Szőkedencs-Cölömpös-árok (Kulcsár 2009, 237. 217. lh.)), vagy a meredekebb domboldalakon (KeszthelyHalászcsárda (MRT1 1966, 1. kieg 21/49. lh; Bondár et al. 1996, 53. 9. lh.; Kulcsár 2009, 237. 107. lh.) és Sármellék (MRT1 1966, 139. 40/11-12. lh; Bondár et al. 1996, 53. 68. lh.), találhatóak. További két lelőhely azonban a Kis-Balaton szigetein (Balatonmagyaród-Szarkavári-sziget (Bondár et al. 1996, 53. 116. lh; Kulcsár 2009, 236. 18. lh.) és Sávoly-Nyírfás-szigeten (Bondár et al. 1996, 53. 166. lh; Kulcsár 2009, 237. 186. lh.) helyezkednek el.

A vízszint fokozatos emelése esetén a modellben a vízállás 105-108 méter közötti szinteken jól megfigyelhető módon nem érinti a part menti lejtők magasabb régióiban és a parttól távolabb elhelyezkedő lelőhelyeket (8.11-8.12. ábra). Szegerdő-Legelői-dűlő lelőhely esetében azonban 108 méteres vízállásnál egy keskeny és sekély mellék-öblözet alakul ki, így a lelőhely közvetlenül a vízpart közelébe kerül. A parttól távolabb lévő lelőhelyek alapján felvázolható, hogy a kora bronzkor kezdeti szakaszában elképzelhető egy magasabb balatoni vízállás, ugyanis az emelkedő víz által befolyásolt zónában nem találunk a korszakhoz tartozó lelőhelyeket. Ezt a megfigyelést erősítik a két balatonkeresztúri lelőhelyen feltárt jelenségek, amelyek a lejtő magasabb térszínein voltak megtalálhatóak. Ugyan ezt a megfigyelést erősíti a Fonyód-Vasúti-dűlő (Honti et al. 2007, 26. Kulcsár 2009, 237. 61. lh.) lelőhelyen feltárt kisszámú, az időszakhoz köthető beásás 108 méter feletti elhelyezkedése.

Részben ellent mondanak viszont a megfigyelésnek a kis-balatoni szigetek lelőhelyei. Vörs-Nyíresszigeti lelőhely (Bondár et al. 1996, 54. 152. lh; Kulcsár 2009, 237. 240. lh.) még 108 méteres vízállás esetén is jócskán, több mint 3 méterrel a vízszint fölé emelkedik, habár területe csak 0,8 hektár (8.12. ábra). Ezzel szemben a Kis-Balaton keleti medencéjében lévő Balatonmagyaród- 
Szarkavári-sziget (Bondár et al. 1996, 53. 116. lh) már 106 méteres vízállás esetén is alkalmatlanná válik a tartós megtelepedésre, a legmagasabb pontja alig emelkedik a víztükör szintje fölé (8.11. ábra).

A Balatonmagyaród-Szarkavári szigeten megfigyelt eset ellenére, összefoglalva a kevés lelőhely alapján a Somogyvár-Vinkovci kultúra időszakában egy viszonylag magasabb vízállású időszakot valószínűsíthetünk. A vízállás az időszakban sem haladhatta meg a 108 méteres magasságot, de a kultúra időszakának egyes periódusaiban minden bizonnyal magas vízállás volt jellemző.

\subsubsection{A Kisapostagi kultúra időszaka}

A kora bronzkor második feléből megközelítőleg ugyan annyi lelőhelyet ismerünk a vizsgált területen belül, mint a megelőző időszakból. A lelőhelyek elhelyezkedésében azonban jelentősebb változás figyelhető meg. A korszakhoz köthető megtelepedések közelebb találhatóak a tó partvonalához, a vízszint emelkedésével több lelőhely alkalmatlanná válik a megtelepedésre. A vízállás 105 méteres szintjénél még az összes lelőhely alkalmas a megtelepedésre (8.13. ábra). Abban az esetben, ha a vízszintet egy méterrel 106 méteres szintre emeljük, Zalavár-Vársziget (MRT1 1966, 185. 59/20. lh; Bondár et al. 1996, 54. 85. lh.) lelőhely ténylegesen szigetté alakul. Keszthely-Honvéd utca lelőhely (MRT1 1966, 21/70. lh; Bondár et al. 1996, 53. 10. lh.) egészen a vízpart közelébe kerül (8.13. ábra).

Újabb egy méteres vízszint emelés esetén, 107 méteres vízállásnál VörsMáriaasszony-sziget (Bondár et al. 1996, 54. 140. lh.) is tényleges sziget lesz (8.14. ábra).

A modellben használt vízállásmaximum, a 108 méteres szint esetében KeszthelyHonvéd utca lelőhelyet elönti a Balaton vize, míg Vörs-Máriaasszony-sziget egy ugyan 2 hektár kiterjedésű, ám a víztükör szintje fölé mindössze 0,5 méterrel magasodó, emberi megtelepedésre alkalmatlan szigetté válik (8.14. ábra).

Összefoglalva a kora bronzkor két időszakára a lelőhelyek geomorfológiai elhelyezkedéséből és a vízborítási modellből levonható, a vízállás változásaira vonatkozó következtetéseket, az állapítható meg, hogy az időszak elején egy feltételezhető, magasabb vízállású időszak volt. A vízállás tengerszint feletti 
értékének megállapítására a modell nem alkalmas, azonban a lelőhelyek elhelyezkedése alapján akár a modell felső határértékének közelében valószínűsíthető. A kora bronzkor második felében a vízállás minden bizonnyal csökkent, így a Kisapostagi kultúra időszakára keltezhető telepek a vízparthoz közelebbi részeken és a vízállás emelkedésével szigetekké alakuló területeken találhatóak.

\subsubsection{A kora bronzkori időszak több korszakú lelőhelyei}

A vizsgálat alá vont területen a modellben használt lelőhelyek közül mindössze kettő található, amelyeken mind a két kultúrához köthető települési objektumok megtalálhatóak (Balatonmagyaród-Hídvégpuszta, TikosHomokgödrök). A rendkívül alacsony lelőhelyszám és a két lelőhelynek eltérő geomorfológiai környezetben való elhelyezkedése, illetve a partvonalhoz képest eltérő távolsága miatt a vízállásváltozás tendenciáira nézve nem vonhatóak le megalapozott következtetések.

\subsection{A középső bronzkor időszaka}

A középső rézkori Mészbetétes Kerámia kultúra időszakára keltezhető önálló településnyomok szintén viszonylag kis számban álltak rendelkezésemre a vizsgált területen. Az alacsony számuk mellett ezen felül rendkívül változatos képet is mutattak. A lelőhelyek egy része a modell maximális vízborítása esetén is partvonaltól távol helyezkedik el (Zalavár-Ürmöspuszta (MRT1 1966, 184. 59/16. lh; Bondár et al. 1996, 55. 89. lh; Kiss 2012, 312. 400. lh.)), BalatonszentgyörgyTéglagyár (Bondár et al. 1996, 53. 191. lh; Kiss 2012, 272. 40. lh.)). Emellett egy lelőhely, Zalavár-Ökör-sziget (MRT1 1966, 189. 59/31. lh; Bondár et al. 1996, 55. 76. lh; Kiss 2012, 312. 399. lh.) alacsony vízállás esetén a tó partvonalához közel, alacsony szintmagasságú részen található (8.15. ábra). Ezen kívül egy másik lelőhely, a Kis-Balaton szigetén, Sávoly-Fekete-szigeten (Bondár et al. 1996, 53. 154. lh; Kiss 2012, 294. 271. lh.) található. 
Egy méteres vízemelkedés esetén, 106 méteres vízállás esetén Zalavár-Ökörsziget ténylegesen szigetté válik, Sávoly-Fekete-sziget területe pedig jelentősen leszűkül (8.15. ábra).

Ismételt egy méteres vízemelkedés esetén 107 méteres vízállásnál Zalavár-Ökörsziget területe kicsire zsugorodik, alig fél, egy méterre emelkedik ki a Balaton felszíne fölé. Ennél a vízállásnál a sziget emberi megtelepedésre alkalmatlan (8.16. ábra).

A modell vízállásmaximumát jelentő 108 méteres szint esetén jelentősebb változás nem történik, a már korábban lakhatatlanná váló Zalavár-Ökörszigetet teljes mértékben elfedi a tó vize. Sávoly-Fekete-sziget, amely a Kis-Balaton szigetei közül a legmagasabban emelkedik ki a tóból, 108 méteres vízállásnál is alkalmas a megtelepedésre. A partvonaltól távolabb lévő települések továbbra sem érintettek a tó közvetlen vízingadozása által (8.16. ábra).

A középső bronzkori időszakra a vízborítási modell eredményeiből messzemenő következtetéseket nem lehet levonni, köszönhetően a változatos lelőhely elhelyezkedéseknek. A szigeteken megfigyelt tendenciák alapján annyi valószínűsíthető, hogy az időszakban a korábbi, Kisapostagi kultúra időszakához képest lényeges eltérés nem mutatkozik.

\subsection{A kora és középső bronzkori több korszakú lelőhelyek}

Abban az esetben, ha azokat a lelőhelyeket jelenítjük meg a modellben, amelyeken Kisapostagi kultúra és a Mészbetétes Kerámia kultúra megtelepedései egyaránt megtalálhatóak, akkor megfigyelhetünk egy alacsonyabb vízállású időszakot a két kultúra váltásának időszakában. A mindkét időszakban lakott telepek Keszthely-Fenékpuszta (Bóna 1964, 42; MRT1 1966, 79-80. 21/23. lh; Kalicz-Schreiber 1991, Abb.4; Bondár et al. 1996, 53. 15. lh; Kiss 2012, 284. 163. lh.), Vörs-Kerékerdő (Bándi 1967, 16; Bondár et al. 1996, 54. 141. lh; Kiss 2012, 311. 392. lh.), Vörs-Papkert B (Bondár et al. 1996, 54. 143. lh; Kiss 2012, 311. 394. lh.) a Balaton alacsony vízállású időszakaiban is a part közelében helyezkedtek el. Keszthely-Fenékpuszta és Vörs-Kerékerdő enyhe lejtésű, alacsonyabban fekvő területeken, míg Vörs-Papkert B egy meredekebb oldalú 
magaslaton, de közvetlenül a 105 méteres vízállás partvonalának közelében találhatóak (8.17. ábra).

A vízszint egyméteres emelkedése esetén, 106 méteres vízálláskor Vörs-Papkert B lelőhelyet körbeveszi a Balaton, a terület szigetté válik, Vörs-Kerékerdő lelőhelynek helyet adó félsziget pedig tovább szűkül (8.17. ábra). Újabb egy méteres vízszintemelkedés esetén 107 méteres értéknél mindkét lelőhely egyre kisebb területre szorul vissza, Vörs-Kerékerdő lelőhely már kis híján szigetté alakul (8.18. ábra).

A modell vízállásmaximumánál, 108 méteres vízállásnál Vörs-Kerékerdő szigetté alakul, területe jelentősen lecsökken és csak egy méterrel emelkedik a legmagasabb pontja a víztükör szintje fölé. Ilyen vízállásviszonyok mellett a szigeten emberi megtelepedés nem valószínűsíthető (8.18. ábra).

A kora és középső bronzkor időszakából a vizsgált területen mindössze egyetlen olyan lelőhelyet ismerünk Vörs-Battyáni-disznólegelő (Bondár et al. 1996, 54. 138. lh. Kulcsár 2009, 237. 237. lh; Kiss 2012, 310. 390. lh.), ahol mind a három periódus megtelepedései megtalálhatóak.

A kora és középső bronzkor időszakának vízállás tendenciáiról, a vízkitöltési modell és a lelőhelyek elhelyezkedése alapján összefoglalóan azt lehet felvázolni, hogy a Somogyvár-Vinkovci kultúra időszakára magasabb vízállás valószínűsíthető, ami a Kisapostagi kultúra időszakára alábbszáll és ezzel nagyjából megegyező vízállásviszonyok lehetnek a középső bronzkor idején is. Egy alacsonyabb vízállású időszak a két időszak határán valószínűsíthető, ugyanis azok a lelőhelyek vannak az emelkedő vízállás által erősebben befolyásolt területeken, amelyeken mind a két időszak, a Kisapostagi kultúra és a Mészbetétes Kerámia kultúra megtelepedésének nyomai egyaránt kimutathatóak.

\subsection{A késő bronzkor időszaka}

A késő bronzkor időszakából viszonylag nagyszámú lelőhelyet ismerünk a vizsgált területről. Ez az időszak abból a szempontból is fontos, mert mint azt már többször említettem, az Ordacsehi-Kistöltés lelőhelyen a korszak végére, jól bizonyíthatóan rendkívül magas, a modell maximumértékét megközelítő vízállásadatok állnak rendelkezésünkre. Ennek kapcsán, hipotézis szintjén 
felmerült, hogy a korszak megtelepedésének hiányát a balatonkeresztúri lelőhelyen, értelmezhetjük-e egy magasabb vízállású időszak indirekt bizonyítékaként.

A késő bronzkori lelőhelyek geomorfológia elhelyezkedése nagy számuknak köszönhetően változatos képet mutat. Az elemzés szempontjából azok a lelőhelyek voltak elsődlegesen fontosak, amelyek már alacsony vízállási értéknél is partközeli részen találhatóak (8.19. ábra). Ezek BalatonmagyaródHídvégpuszta (Horváth 1994, 219-221; Bondár et al. 1996, 72. 113. lh.), FőnyedGólyásfa (Bondár et al. 1996, 72. 155. lh.), Keszthely-Halászcsárda (MRT1 1966, 95. 21/61. lh; Bondár et al. 1996, 72. 9. lh.), Sármellék-Bekötőút (MRT1 1966, 139. 40/12. lh; Bondár et al. 1996, 73. 66. lh.), Vörs-Battyáni-disznólegelő (Honti 1994, 147-155; Bondár et al. 1996, 138. 138. lh.), Vörs-Papkert C (Bondár et al. 1996, 73. 144. lh.), és Zalavár-Ökörsziget (Bondár et al. 1996, 73. 76. lh.). Valamint a Kis-Balaton szigetein észlelt lelőhelyek, mint BalatonmagyaródKányavári-sziget (Bondár et al. 1996, 72. 114. lh), Balatonmagyaród-Brúnersziget (Bondár et al. 1996, 72, 112. lh.), Sávoly-Nyírfás-sziget (Bondár et al. 1996, 73. 166. lh.), Vörs-Papkert A (Bondár et al. 1996, 73. 142. lh.).

Egy méteres vízszintemelkedés esetén, 106 méteres vízállásnál a korábban még part közeli Zalavár-Ökörsziget és Vörs-Papkert C lelőhelyek környéke ténylegesen szigetté válik, a Kis-Balatonban lévő szigetek használható területe jelentősen lecsökken, Vörs-Battyáni-disznólegelő lelőhely egy erősen leszűkülő félszigetre szorul (8.19. ábra).

Még egy méterrel magasabb 107 méteres vízállásnál Főnyed-Gólyásfa lelőhelyet elborítja a tó, Balatonmagyaród-Brúner-sziget csaknem egészét elönti a Balaton, csak egy kis rész kerül a vízfelszín fölé alig fél méterrel. Ebben az esetben a sziget területe megtelepedésre alkalmatlanná vált. Vörs-Battyáni-disznóllegelőt körülzárja a tó vize, kis szigetté alakul, amely alig egy méterrel emelkedik ki a nyílt víztükörből. Nagy valószínűséggel ez a lelőhely is alkalmatlanná vált a megtelepedésre 107 méteres vízállás esetén (8.20. ábra). A többi sziget területe folyamatosan zsugorodik.

A modell 108 méteres vízállásmaximumánál Balatonmagyaród-Kányavári-sziget és talán Vörs-Papkert C lelőhely északi része kivételével a szigetek, valamint a szigetekké alakult partközeli települések alkalmatlanná válnak a megtelepedésre. 
A partvonaltól távolabb lévő és a magasabb tengerszint feletti magasságú régiókban elhelyezkedő településeket továbbra sem befolyásolja közvetlenül a tó vízszintjének emelkedése (8.20. ábra).

Összefoglalásul megfogalmazhatom, hogy a modell a Kis-Balaton környéki késő bronzkori megtelepedések esetében nem igazolta, a magas vízállás hipotézisét a teljes időszakra. Elképzelhető, hogy az időszak végén tényleg volt egy jelentős vízszintváltozás, de hogy ez miként érintette késő bronzkori telepeket a vizsgált régióban azt a modell alapján nem lehet megállapítani.

\subsection{A késő vaskor időszaka}

A késő vaskori megtelepedések geomorfológiai elhelyezkedése nem sokban különbözik a késő bronzkori lelőhelyeknél megfigyelt jellegtől. A települések egy része szintén az alacsony vízállású partvonal közelében található, úgymint Főnyed-Gólyásfa (Horváth et al. 1996, 82. 155. lh.), Vörs-Battyánidisznólegelő (Horváth et al. 1996, 82. 13. lh.), Vörs-Kerékerdő (Horváth et al. 1996, 82. 141. lh.) és Vörs-Papkert B (Horváth et al. 1996, 82. 143. lh.). Néhány lelőhely megtalálható a Kis-Balatonban lévő szigeteken, ezek BalatonmagyaródKányavári-sziget (Horváth 1987, 60-61; Horváth et al. 1996, 82. 114. lh.), Balatonmagyaród-Szarkavári-sziget (Horváth 1987, 59-60; Horváth et al. 1996, 82. 117. lh) valamint Vörs-Papkert A (Horváth 1996, 82. 142. lh.).

Az M7 autópálya nyomvonalában előkerült késő vaskori megtelepedések, Szegerdő-Marótvölgyi-csatorna (Honti et al. 2007, 18-19.), SzőkedencsCölömpös-árok (Honti et al. 2007, 20-22.), Tikos-Bari-dűlő (Honti et al. 2007, 15.), Tikos-Nyárfás-dűlő (Honti et al. 2007, 15-16.) jelentős távolságban vannak a tó partvonalától, ebből adódóan a megtelepedés viszonyaira a Balaton vízállása közvetlen hatással nem volt, a talajvíz mozgásáról ezeken a területeken egyelőre nem rendelkezem adatokkal. Az autópálya nyomvonalába eső lelőhelyek közül Szegerdő-Marótvölgyi-csatorna lelőhely jelenti az egyetlen kivétel, ugyanis magasabb vízállású időszakokban a Balaton elöntötte a mai Marótvölgyet, így a település ilyen esetben rendelkezett közvetlen tavi kapcsolattal (8.21. ábra).

A vízszint egy méteres emelkedésével, 106 méteres vízállásnál Főnyed-Gólyásfa lelőhely egy nagyon kis területű szigetté zsugorodik, Vörs-Battyáni-disznólegelő 
körül nagy területeket foglalt el a víz és a lelőhely egy szűk félszigetre szorult. Vörs-Papkert B lelőhelyet körbeveszi a tó, a lelőhely és környéke szigetté változik, a már korábban is szigeteken lévő lelőhelyek körül a használható területek jelentősen szűkülnek (8.21. ábra).

Újabb egy méteres vízszintemelkedés esetén 107 máteres szintnél FőnyedGólyásfa és Balatonmagyaród-Szarkavári-sziget lelőhelyek teljesen víz alá kerülnek. Vörs-Battyáni-disznólegelő ennél a vízállásnál már szigetté alakul, Vörs-Kerékerdő lelőhelyet kevés híján körbeveszi a Balaton az egyelőre félszigetszerű terület jelentősen leszűkül.

A Balaton 107 méteres vízállás esetén elönti a Marótvölgyet, így az M7 autópálya nyomvonalában lévő Szegerdő-Marótvölgyi-csatorna lelőhely vízpart közeli településsé válik (8.22. ábra).

A modell vízállásmaximumánál a tó vize teljesen elborítja Vörs-Battyánidisznólegelő és Vörs-Papkert A és Vörs-Kerékerdő lelőhelyeket, így ezek ennél a vízállásnál emberi megtelepedésre alkalmatlan szigetekké válnak. A szigetek közül csak Balatonmagyaród-Kányavári-szigeten és a vízállás emelkedés során szigetté váló Vörs-Papkert B lelőhelyeken feltételezhetőek megtelepedésre alkalmas körülmények (8.22. ábra).

A késő vaskori vízállás tendenciáiról a vízkitöltési modell és a korszak lelőhelyeinek geomorfológiai elhelyezkedése közötti összefüggések alapján összefoglalóan azt lehet elmondani, hogy a korszak jelenségei sok hasonlóságot mutatnak a késő bronzkor időszakánál tárgyalt tendenciákkal. Az OrdacsehiKistöltés lelőhelyen feltárt árokban észlelt, 107 méter feletti tavi hullámzási nyomok alapján a késő bronzkor végére, kora vaskor elejére keltezhető magas vízállás a későbbiekben nem maradhatott fent, legkésőbb a késő vaskor időszakára visszatért a késő bronzkorban tapasztalt szintre.

Mint már korábban, a balatonkeresztúri lelőhely késő vaskori megtelepedési viszonyai kapcsán említettem, az úgynevezett „pannoniai tölgykronológia” (Grynaeus 2004, 93-94.) a Kr.e. 2. század időszakára nagy biztonsággal száraz és meleg éghajlati viszonyokat mutat. A Kis-Balaton partvonalának közelében és a szigeteken lévő lelőhelyek alapján azonban nem fedezhető fel kiugróan alacsony vízállás a többi vizsgált időszakhoz képest. 


\subsection{A kora rómaikor időszaka}

A vizsgált terület kora császárkorra keltezett lelőhelyeit két csoportra bontottam. Az egyik csoportba az úgynevezett falusias jellegű telepeket soroltam, míg a másodikban a tégla és kő építményekkel együtt azonosított, kora császárkori leletanyaggal datált lelőhelyek kerültek.

A megkülönböztetésre azért volt szükség, mert a kutatásban régóta meglévő vélemény, hogy a Balaton déli partja közelében a falusias jellegű telepek valójában a római uralom ideje alatt is tovább élő bennszülött, kelta lakosságnak a megtelepedései (Szabó 1963, 72-72; Gabler 1982, 73; Müller 1996, 85.). Az M7 autópálya nyomvonalának feltárásai nagymennyiségű, újabb adattal járultak hozzá ehhez a kérdéskörhöz (Németh 2007, 42-43; Serlegi 2007, 299-300; Serlegi 2009, 502.). Ordacsehi-Bugaszeg, (Honti et al. 2002, 15-20; Honti et al. 2004, 4044.) Ordacsehi-Cserföld (Honti et al. 2002, 20-23.) , Balatonboglár-Berekre-dűlő (Honti et al. 2002, 28-31.), Balatonlelle-Kenderföld (Honti et al. 2004, 15-18; 5456.), Balatonszemes-Szemesi-berek (Honti et al. 2002, 6-9.), BalatonszemesEgyenes-dűlő (Honti et al. 2004, 29-31.) Baltonlelle-Rádpuszta-Romtemplommellett (Honti et al. 2007, 51-56), Tikos-Homokgödrök (Honti et al. 2004, 45-47; Honti et al. 2007, 15-17.) és Szőkedencs-Cölömpös-árok (Honti et al. 2007, 2022.) lelőhelyek kevert, jellegzetes késő vaskori és Kr.u. 2-3. századi római leletanyaga, valamint a települési objektumok jellege jól bizonyítja a császárkor korai szakaszában is létező bennszülött telepeket.

A másik csoportba azok a lelőhelyek kerültek, amelyeken jellegzetes római kori építőanyagok maradványait (falazótégla, imbrex) és más kőépületekre utaló nyomok kerültek elő. A jellegzetes római kori építkezés nyomai alapján feltételezhető, hogy ezeknek a lelőhelyeknek nem volt késő vaskori előzménye.

A vaskori előzményekkel rendelkező lelőhelyekről szintén elmondható, hogy az M7 autópálya nyomvonalába eső lelőhelyek (Tikos-Homokgödrök (Honti et al. 2004, 45-47; Honti et al. 2007, 15-17.), Szőkedencs-Cölömpös-árok (Honti et al. 2007, 20-22.)) esetében nem lehet feltételezni direkt kapcsolatot a tó vízborítása és a település geomorfológiai helyzete között. 
A modell vízállásminimuma, 105 méteres vízszint esetén az autópálya nyomvonalába eső lelőhelyek valamint Sávoly-Sziget-dűlő lelőhelyek kivételével a települések a partvonal közelében helyezkednek el (8.23. ábra).

A vízszint egy méterrel való emelése esetén, 106 méteres vízszintnél Balatonmagyaród-Szarkavári-dűlőt (Horváth et al. 1996, 88. 118. lh.) elönti a tó vize, Balatonmagyaród-Szarkavári-sziget (Horváth et al, 1996, 88. 116. lh.) területe jelentősen leszűkül. Vörs-Battyáni-disznólegelő a környéke a Balatonba nyúló keskeny félszigetté válik (8.23. ábra).

Újabb egy méteres vízemelkedés esetén, 107 méteres vízállásnál Balatonmagyaród-Szarkavári-szigetet elfedi a víz. Vörs-Battyáni-disznólegelő területét teljesen körbeveszi a Balaton, alacsony, kiterjedésű szigetté válik. VörsKerékerdő (Horváth et al. 1996, 90. 141. lh.) területét kevés híján a Balaton elvágja a szárazföldtől. Sávoly-Szigeti-dűlő (Horváth et al. 1996, 89. 179. lh.) a Marótvölgy víz alá kerülésével a vízpart közelébe kerül (8.24. ábra).

A modell vízállásmaximumánál, 108 méteres szintnél a tó szinte teljesen elönti Vörs-Battyáni-disznólegelő és Vörs-Kerékerdő területét, a lelőhelyek megtelepedésre alkalmatlanokká válnak (8.24. ábra).

A második csoportba tartozó, kő- és téglaépítményeket is magukba foglaló lelőhelyek közül három, Balatonszentgyörgy (Horváth et al. 1996, 88. 172. lh.), Keszthely-Pusztatemplom (MRT1 1966, 79. 21/17. lh; Horváth et al. 1996, 89. 16. lh.) és Zalavár-Nedám (MRT1 1966, 188. 59/25. lh; Horváth et al. 1996, 91. 86. lh;) jól megfigyelhető módon a domblejtők meredekebb szakaszain helyezkednek el. Egyetlen lelőhely helyezkedik el a Kis-Balaton szigetén, Vörs-Pogány-sziget (Horváth et al. 1996, 90-91. 182. lh.).

A modell vízállásminimumánál a part menti lelőhelyeket nem veszélyezteti a tó vízállása, a domblejtők felsőbb szakaszait nem érinti a közvetlen vízingadozás. Vörs-Pogány-sziget mintegy 5 méterrel emelkedik a víz szintje fölé (8.25. ábra). Egy méteres vízemelkedés esetén, 106 méteres vízállásnál, a tó szinte körbeveszi Balatonszentgyörgy lelőhelyet, Vörs-Pogány-sziget két, kisebb kiemelkedésből álló szigetre válik szét, az alacsonyabb részeket elönti a Balaton vize (8.25. ábra). Amennyiben újabb egy métert, 107 méteres szintre emelkedik a tó vize, abban az esetben Vörs-Pogány-sziget déli kiemelkedését is elönti a tó, Balatonszentgyörgy 
lelőhely pedig egy kis kiterjedésű, tagolt partvonalú félszigetre szorul vissza (8.26. ábra).

A modell vízállásmaximumánál, 108 méteres vízállás esetén Vörs-Pogány-sziget egy rendkívül kicsi, de a vízből alig egy méterre kimagasló szigetté válik. Ilyen körülmények között nem valószínű, hogy egy kőépítmény és melléképületei lakhatók és fenntarthatók lennének, ha beleszámoljuk a tó hullámzás általi vízmagasodását is. Ugyan ezek a megfontolások érvényesek a 108 méteres szintnél szigetté váló Balatonszentgyörgyi lelőhely esetében is (8.26. ábra).

A vízkitöltési modell és a vizsgált terület késő vaskori, római kori bennszülött településeinek, valamint kő- és téglaépítkezéseinek összefüggései alapján azt a következtetést lehet levonni, hogy az egymást követő időszakok lelőhelyeinek geomorfológiai elhelyezkedése nem mutat lényeges vízállásváltozást az időszakon belül. Közvetett adatokra alapozva azonban valószínűsíthetünk egy olyan volumenű környezeti változást, feltehetően a késő vaskor legvége felé, amely hatással lehetett a bennszülött lakosság életkörülményeire. Mint már említettem, az őslakosság zavartalan továbbélését a római uralom kezdete után korábban is feltételezte a kutatás, aminek jó bizonyítékát szolgáltatták az autópálya nyomvonalában feltárt kora császárkori bennszülött települések. Mind a kis-balatoni régióban, mind a Balaton egykori partvonala mentén kimutathatóak azonban olyan megtelepedések, amelyek léteznek a késő vaskorban, de császárkori továbbélésük nem bizonyítható. Az M7 autópálya nyomvonalában feltárt Ordacsehi-Kistöltés, Balatonősződ-Temetőidűlő (Honti et al. 2004, 23-25.), Zamárdi-Kútvölgyi-dűlő (Honti et al. 2004, 47 51.), valamint a részletesen tárgyalt Balatonkeresztúr-Réti-dűlő lelőhelyek késő vaskori időszakán túl, nem ismert kora császárkori periódusa (Serlegi 2007, 299300.). A feldolgozottság jelen állapotában nem dönthető el, hogy a felsorolt késő vaskori településeknek mi az időbeli felső határa, de az bizonyos, hogy a Kr.u. 2. század második felében a területen megjelenő jellegzetes római kori leletanyag nem található meg a feltárt objektumokban. A Zamárditól Szőkedencsig tartó, a Balaton teljes természetes, déli partvonalát keresztülvágó 80 kilométeres szakaszon, valamint a Kis-Balaton régiójában ilyen nagy számban, minden szabályosságot nélkülöző módon előforduló tovább élő illetve megszűnő telepek jelensége mögött egy környezeti változást sejthetünk. A Badeni kultúra 
időszakára eső, jól dokumentált éghajlati ingadozás adataiból kiindulva elképzelhetőnek tartom, hogy a késő vaskorban is előfordulhatott egy a késő rézkorihoz hasonló klímaesemény. Ennek volumenéről közvetlen adataink nincsenek, de elképzelhető, hogy hatására ebben a korszakban bizonyos esetekben előfordulnak településfelhagyások. A kérdésre azonban a késő vaskori telepek természettudományos vizsgálatokkal, talajvízmozgási rekonstrukcióval kiegészített, szisztematikus belső kronológiai és településszerkezeti kutatásának befejezéséig megnyugtató választ nem lehet adni.

A vízkitöltési modell és a települések tóhoz viszonyított helyzetének összefüggései alapján jelen pillanatban mindössze annyi állapítható meg, hogy abban az esetben, ha volt is a késő vaskor végén egy rövidebb lefolyású klimatikus ingadozás, az éghajlati körülmények a római kor első évszázadaira visszaálltak a késő vaskorihoz hasonlóra.

\subsection{A több korszakú lelőhelyekből levonható következtetések}

A vízborítási modell szintértékei és a partvonal közelében elhelyezkedő emberi megtelepedések geomorfológiai viszonyai közötti összefüggések tanulmányozása szempontjából a legtöbb információt azok a lelőhelyek adhatják, amelyeken a balatonkeresztúron feltárt lelőhelyhez hasonlóan számos időszak megtelepedései megtalálhatók.

Az M7 autópálya nyomvonalába eső lelőhelyek feltárási adatai alapján arra lehet következtni, hogy a Balaton és környékének természetes környezeti állapota esetén a mesterséges beavatkozásoktól mentes hidrológiai viszonyok között a megtelepedésre alkalmas helyek korlátozott számban álltak rendelkezésre. Ez az oka annak, hogy a balatoni berkek és a közöttük húzódó meridionális dombhátak határán lévő lelőhelyeken az esetek túlnyomó többségében számos korszak megtelepedését lehetett azonosítani (Bondár et al. 2001, 91-114; Honti et al. 2002, 3-36, Honti et al. 2004, 3-70, Honti et al. 2007, 7-70.).

Feltételezhető ez alapján, hogy időben egymástól több ezer év távolságra lévő, eltérő kulturális tradíciókkal, hiedelemvilággal és gazdálkodásmóddal rendelkező, mégis azonos geomorfológiai körülmények között megtelepedő időszakok népességeit a település helyének kiválasztása során elsősorban a 
kulturális tényezőktől mentes, gyakorlati szempontok irányították. Minden bizonnyal ezeket a gyakorlatias szempontokat a környezeti tényezők alapvetően befolyásolták.

A vizsgálat alá vont területen a lelőhelyek nagy részén egynél több időszak megtelepüléseinek objektumai láttak napvilágot. Vizsgálatom szempontjából több korszakú lelőhelynek azokat a lelőhelyeket vettem, amelyen a fenti, korszakos bontás alapján legalább négy különböző időszak megtelepedése megtalálhatóak voltak. Ilyen lelőhelyből összesen 10 volt, amelyből 2 az M7 autópálya nyomvonalában (Szőkedencs-Cölömpös-árok - 5 korszak, Tikos.-Homokgödrök 5 korszak), míg a többi 8 a Kis-Balaton térségében (BalatonmagyaródHídvégpuszta - 8 korszak, Balatonmagyaród-Kányavári-sziget - 4 korszak, Balatonmagyaród-Kiskányavár - 4 korszak, Balatonmagyaród-Szarkavári-sziget 5 korszak, Keszthely-Fenékpuszta - 5 korszak, Keszthely-Gáti-domb - 4 korszak, Vörs-Battyáni-disznólegelő - 7 korszak, Vörs-Kerékerdő - 5 korszak) található.

A 10 lelőhelyből 5 a balatonkeresztúri lelőhelyhez hasonlóan a dombhátak meredekebb lejtőin, vagy magasabban térszínű platókon helyezkednek el (Szőkedencs-Cölömpös-árok, Tikos.-Homokgödrök, BalatonmagyaródKiskányavár, Keszthely-Fenékpuszta, Keszthely-Gáti-domb), amelyek esetében a tó vízszintjének nincsen közvetlen hatása a megtelepedésre.

A szigeteken lévő és a partvonal közelében elhelyezkedő telepek 105 méteres vízállásnál megtelepedésre alkalmasnak tűnnek, bár BalatonmagyaródSzarkavári-sziget területe nem túl nagy, alig egy hektár (8.27. ábra).

A vízállás egy méterrel való emelése, 106 méteres vízszint esetén Balatonmagyaród-Szarkavári-sziget két kisebb szigetre esik szét, a legmagasabb pontja körüli északi rész területe már alig fél hektár kiterjedésű és mindössze egy méterrel magasodik a vízszint fölé. Vörs-Battyáni-disznólegelő lelőhely egy szűk, három oldalról vízzel körülvett félszigetre szorul (8.27. ábra).

Újabb egy méteres vízszintemelkedés esetén, 107 méteres vízállásnál Balatonmagyaród-Szarkavári-szigetet teljesen elönti a Balaton vize. VörsBattyáni-disznólegelő egy 3 hektár méretű szigetre szorul vissza, legmagasabb pontja mindössze egy méterrel van a víz szintje felett. Vörs-Kerékerdő lelőhelyet kevés híján szintén körbezárja a víz (8.28. ábra). 
A vízkitöltési modell maximumánál Vörs-Battyáni-disznólegelő egy 0,2 hektáros egy méter magas, megtelepedésre alkalmatlan szigetté zsugorodik. VörsKerékerdőt is körbezárja a víz, legmagasabb pontja csak egy méterrel emelkedik ki a vízből. Balatonmagyaród-Kányavári-sziget is két kisebb szigetre válik szét, azonban az északi része mind mérete, mind kiemelkedése alapján alkalmasnak tűnik a megtelepedésre (8.28. ábra).

A több korszakú lelőhelyek elemzése alapján arra következtethetek, hogy a balatonkeresztúri lelőhelyhez hasonlóan, a balatoni öblök között húzódó meridionális hátak lejtői minden időszakban megfelelő helyet biztosítottak a megtelepedésre.

A part menti lelőhelyek és a szigetek megtelepedései már sokkal változatosabb képet mutatnak. Balatonmagyaród-Kányavári szigetről, amely a vizsgált legmagasabb vízállási érték esetén is alkalmas a megtelepedésre mindössze két korszak, a középső neolitikum és a késő rézkor időszakából ismerünk településnyomokat. Ezzel szemben Balatonmagyaród-Szarkavári szigetről öt időszak, a késő neolitikum-kora rézkor, a középső rézkor, a kora bronzkor, késő vaskor és a kora császárkor időszakainak telepjelenségi is ismertek. A szigetet 107 méteres vízállás esetén már teljesen elönti a tó vize, azonban a talajvízviszonyok és a hullámverés miatt feltételezhető, hogy már 106 méteres magasságú vízállás esetén is alkalmatlan a megtelepedésre, tehát a felsorolt korszakokon belül egy tartósan alacsony vízszintet kell feltételeznem.

A partvonal közelében lévő települések hasonló tendenciákat mutatnak, mint a szigetek lelőhelyei. Vörs-Kerékerdő lelőhelyen, amely a vízállás emelkedésével egy kisebb kiterjedésű, szűk bejáratú félszigetté alakul, majd a modell vízállásmaximumánál egy kis kiterjedésű szigetté válik, 5 régészeti korszakban, a késő neolitikum-kora rézkorban, kora bronzkor második felében, a középső bronzkorban, a késő vaskorban és a kora császárkorban volt lakott. A közelében lévő Vörs-Battyáni-disznólegelőn, amely 106 méteres vízállás esetén egy keskeny félszigetté alakul, majd 107 méteres vízszintnél alig egy méterrel a víz fölé emelkedő, megtelepedésre alkalmatlan szigetté zsugorodik, összesen 7 régészeti időszak, a késő neolitikum-kora rézkor, a kora bronzkor mindkét periódusa, a középső bronzkor, a késő bronzkor, a késő vaskor és a kora császárkor 
időszakának megtelepedései azonosíthatóak. Vörs-Kerékerdő lelőhely mind az 5 megtelepedési időszakának jelenségei megtalálhatóak a szomszédos lelőhelyen is.

\subsection{2 Összegzés}

A tíz régészeti korszak egyenkénti és bizonyos periódusok együttes megtelepedéseinek elemzését követően elmondható, hogy a Balaton régészeti korszakokban feltételezett vízállás tendenciáira elsősorban a több korszakú lelőhelyeken tapasztalható jelenségek alapján következtethetünk. A balatonkeresztúri lelőhely tapasztalatai alapján feltételezhetjük, hogy a több korszakú lelőhelyek azon részénél, amelyek a dombhátak lejtőinek magasabb térszínein, illetve a magasabb tengerszint feletti platókon helyezkednek el, a megtelepülés helyét elsősorban a talajvízviszonyok befolyásolták.

Az ingadozás mértékére jóval több információt hordoznak azok a lelőhelyek, amelyek a vízállás emelkedésével közvetlen kapcsolatba kerülnek a Balatonnal. A két balatonmagyaródi és a két vörsi lelőhelyen feltárt régészeti korszakok egybevetése alapján kiderül, hogy a megtelepedések a négy lelőhelyen lefedik a teljes vizsgált időszakot. A középső neolitikumtól, a kora császárkorig elemzett 10 korszak mindegyike megtalálható a négy lelőhelyen, különböző megoszlásban. Mind a két lelőhelytípusra jellemző, hogy a vízállás emelkedésével a modellben alkalmazott vízállásértékek alapján a vízállásminimum értékéhez viszonyított két méteres vízemelkedés esetén a lelőhelyek emberi megtelepedésre alkalmatlanná válnak. Ennek a mind a négy lelőhelyre általánosítható megállapításnak, valamint annak a ténynek az összekapcsolásából, hogy a négy lelőhely megtelepedései lefedik a teljes vizsgált időintervallumot, arra következtethetünk, hogy a régészeti korszakokban a Balaton hosszú távú vízállás ingadozása belül maradt ezen a két méteres intervallumon. Természetesen a középső neolitikum idejétől, a kora császárkorig tartó időszakon belül bizonyítható rendkívül magas vízállás (Ordacsehi-Kistöltés késő bronzkor végi árkának geoarchaeológiai vizsgálata), valamint a megtelepedés szerkezetére is hatással lévő éghajlati ingadozás (Balatonkeresztúr-Réti-dűlő késő rézkori település komplex vizsgálatának eredményei), ennek ellenére feltételezem, hogy ezek időszakos, és a vizsgált több ezer éves intervallumhoz viszonyítva valószínűleg rövid idejű jelenségek lehettek. 
Megállapítható, hogy pontszerűen térképre vetített, és térinformatikai állományba integrált, néhány gödörből álló feltárásokra, terepbejárási adatokra, valamint nagy felületű feltárások előzetes jelentéseire támaszkodó vizsgálatnak megvannak a határai. Ez alapján meghatározható az a relatív szintmagasságú vízállás-ingadozási tartomány, amelyben a tó vízszintje a régészeti adatok alapján a holocén időszak nagy részében, természetes körülmények között ingadozhatott. A rövid lefolyású, feltehetően klimatikus eseményekhez kapcsolható, az általános tendenciáktól eltérő események azonban, elsősorban a nagy felületű lelőhelyek szisztematikusan feldolgozott, radiokarbon módszerrel keltezett belső kronológiai fázisainak azonosítása, valamint korrelálható környezettörténeti elemzésekkel és más természettudományos vizsgálatokkal kiegészített, komplex kutatása esetén mutathatóak ki.

A Balaton vízállás tendenciái és a települések geomorfológiai összefüggéseinek vizsgálatát a tó természetes állapota mellett tanulmányoztam. Nézetem szerint ez az állapot a késő római időszakban, az antik forrásból is jól ismert időpontban és körülmények között szűnt meg (Sextus Aurelius Victor, Liber de Caesaribus, 40, 9). Ennek az emberi beavatkozásnak eredményeként véleményem szerint nem csak a Balaton, hanem a teljes, Délkelet-Dunántúl természetes hidrológiai rendszere megváltozott (Serlegi 2007, 297-317; Serlegi 2009, 501-514; Pásztókai-Szeőke-Serlegi 2013, 68-79.). Így ennek az összetett, a Balaton medencéjénél jóval nagyobb területeket érintő beavatkozásnak és hatásának vizsgálata és részletes kidolgozása már meghaladná a doktori disszertáció terjedelmi kereteit.

\subsection{A környezeti és kulturális tényezők kapcsolata}

A vízállásváltozások összegzését követően egy rövid gondolat erejéig szeretnék kitérni a megtelepedések geomorfológiai elhelyezkedésének környezeti és kulturális aspektusára. Ennek szemléltetésére jó példa a Balatonmagyaród-Hídvégpuszta lelőhely, amely egy 115 méterig magasodó, északi és keleti irányba a tó felé viszonylag meredek lejtésű kiemelkedésen helyezkedik el. A lelőhelyen összesen 8 régészeti korszak megtelepedései azonosíthatóak a középső neolitikum időszakától a kora császárkorig. A 
lelőhelyről csak a középső rézkori és a késő vaskori megtelepedések nyomait nem ismerjük.

A geomorfológiai elhelyezkedés mellett, a terület „népszerűsége” a régészeti korszakokban részben annak is köszönhető volt, hogy az egymással szemben elhelyezkedő, északi Zalavári- és a déli Balatonmagyaródi-hát között leszűkülő rész, minden korszakban stratégiai fontosságú lehetett az átkelési lehetőség miatt. A mélyebb, mocsári és nyíltvízi jellegű területek között ez a két hát jelentette az egyetlen észak-déli irányú közlekedésre alkalmas útvonalat. A két hát csúcsa között, a Kis-Balaton keleti és nyugati medencéje között leszűkülő tavon ezen a szakaszon volt lehetőség legkönnyebben az átkelésre. A két tényező, a megfelelő geomorfológiai elhelyezkedés és az ellenőrzés gyakorlása szempontjából jelentős stratégiai helyzete jól indokolja BalatonmagyaródHídvégpuszta régészeti fedettségét a legtöbb időszakban. Megállapítható, hogy a település helyének kiválasztásánál a geomorfológiai sajátosságok mellett, amelyek a környezet által meghatározott tényezők, szerepet játszanak a stratégiai megfontolások is, ezeket viszont egyértelműen kulturális elemként kell kezelnünk.

Jól megfigyelhető, hogy az északi Zalavári-hát déli lejtőjének aljában lévő ZalavárBalatonhídvég lelőhelyen jóval kisebb számban, mindössze két korszakból ismerünk telepjelenségeket. Ezen a részen a dél felé néző domboldal jóval enyhébb lejtésű, a vízszint emelkedésével egyre nagyobb területeket önt el a víz. A Zalavári-háton, a 105 méteres vízborítás partvonalához viszonyítva, észak felé több mint egy kilométeres távolságban húzódnak a 110 méter magasságú felszínek, amelyek a vízkitöltési modell és a balatonkeresztúri talajvízmodell alapján az időszakok nagy részében megtelepedésre alkalmas területek voltak. Így az átkelőhely északi oldalán, annak ellenére, hogy stratégiai szempontok a déli oldalhoz hasonlóan indokolnák az intenzív régészeti fedettséget, az enyhe lejtés viszonyok és a tó vízmozgása által közvetlenül érintett területek kiterjedése következtében ez csak néhány korszakban lehetséges.

Balatonmagyaród-Hídvégpuszta és Zalavár-Balatonhídvég lelőhelyek jó bizonyítékai tehát annak, hogy a települések helyének kiválasztásában minden korszakban környezetei és kulturális tényezők együttes hatása volt a meghatározó. Amennyiben az egyik tényező valamilyen okból korlátozott vagy 
hiányzik, az visszatükröződik a régészeti fedettség intenzitásában. A Zalavári-hát déli csúcsa stratégiailag legalább olyan fontos, mint a Balatonmagyaródi-hát északi vége. A magyarázata annak, hogy az intenzíven lakott BalatonmagyaródHídvégpusztával szemben fekvő lelőhelyen nem találunk hasonlóan sűrű megtelepedési nyomokat, a két terület eltérő környezeti viszonyaiban rejlik (8.29. ábra). 

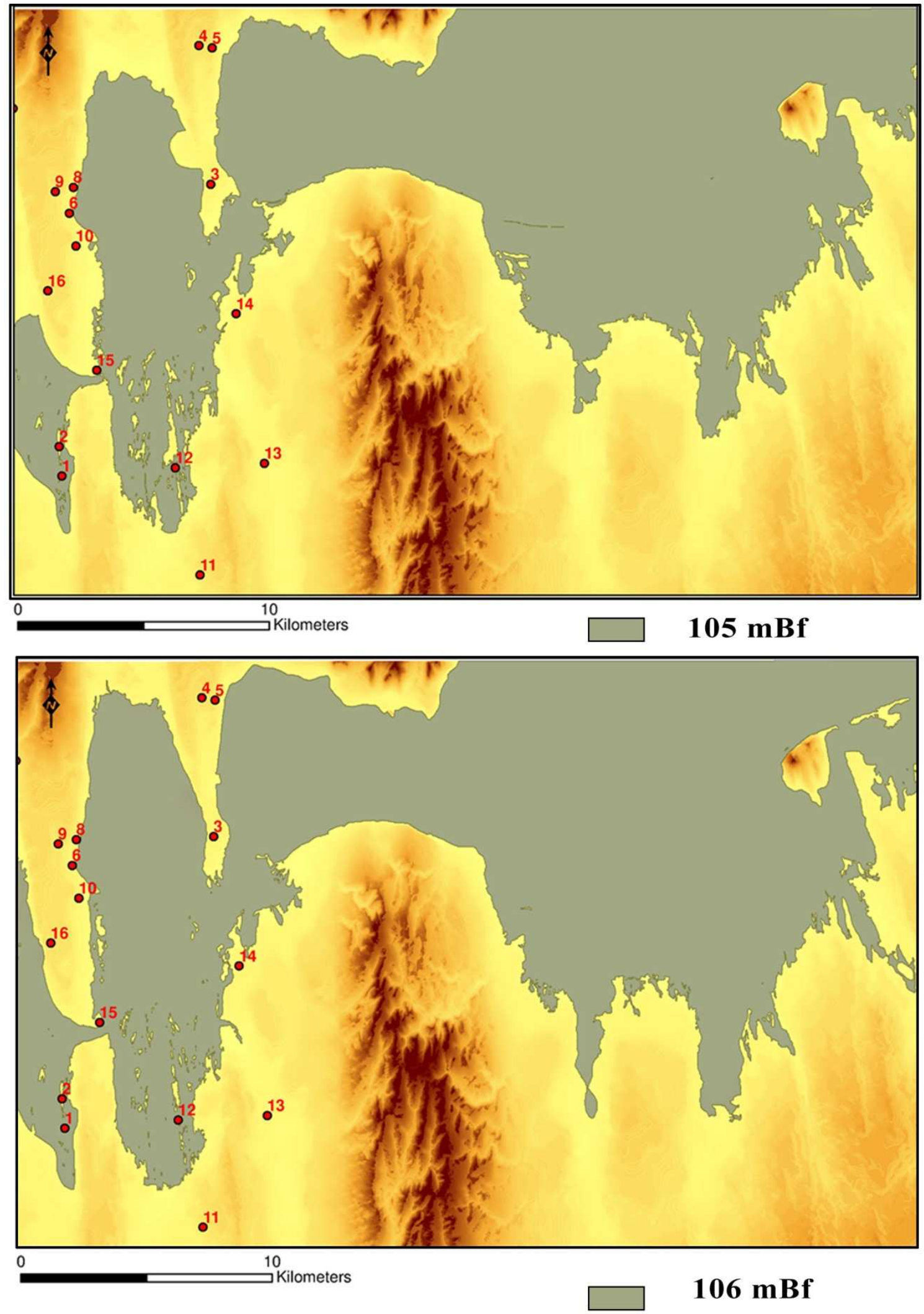

8.1 ábra. A középső neolitikus Vonaldíszes Kerámia kultúrájának lelőhelye: 1. Balatonmagyaród-Brúner-sziget; 2. Balatonmagyaród-Kányavári-sziget; 3. KeszthelyFenékpuszta; 4. Keszthely-Méntelep; 5. Keszthely-Római-út; 6. Sármellék-Agyagbánya; 7. Sármellék-Devecseri-mező; 8. Sármellék-Fenéki-út; 9. Sármellék-Zalavári-domb; 10. Sármellék-Zalavári-határárok; 11. Szőkedencs-Cölömpös-árok; 12. SávolyFekete-sziget; 13. Sávoly-Hupolagos; 14. Vörs-Tótok-dombja; 15. Zalavár-Balatonhídvég; 16. Zalavár-Belterület 

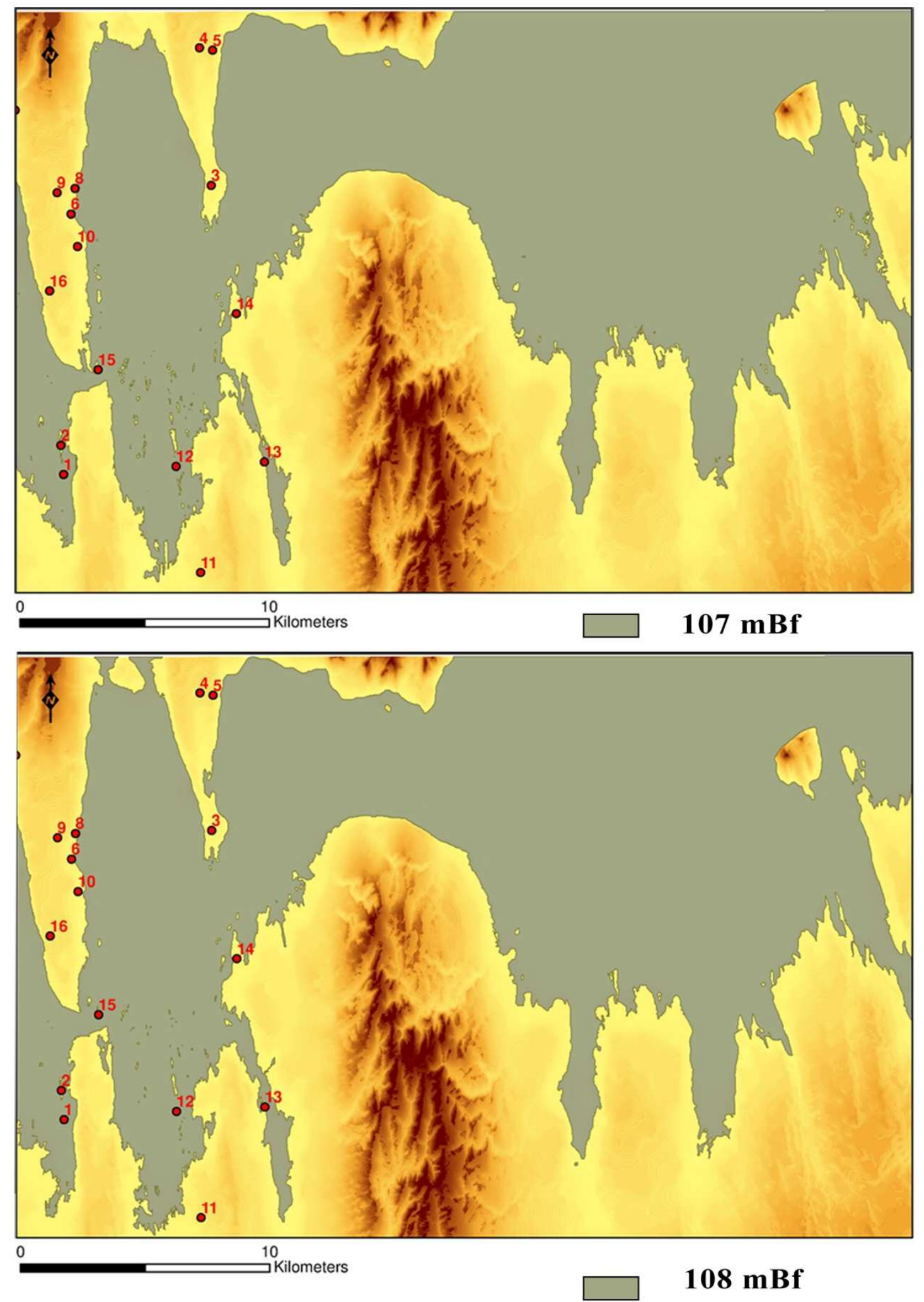

8.2. ábra. A középső neolitikus Vonaldíszes Kerámia kultúrájának lelőhelyei: 1. Balatonmagyaród-Brúner-sziget; 2. Balatonmagyaród-Kányavári-sziget; 3. KeszthelyFenékpuszta; 4. Keszthely-Méntelep; 5. Keszthely-Római-út; 6. Sármellék-Agyagbánya; 7. Sármellék-Devecseri-mezö; 8. Sármellék-Fenéki-út; 9. Sármellék-Zalavári-domb; 10. Sármellék-Zalavári-határárok; 11. Szőkedencs-Cölömpös-árok; 12. SávolyFekete-sziget; 13. Sávoly-Hupolagos; 14. Vörs-Tótok-dombja; 15. Zalavár-Balatonhídvég; 16. Zalavár-Belterület 

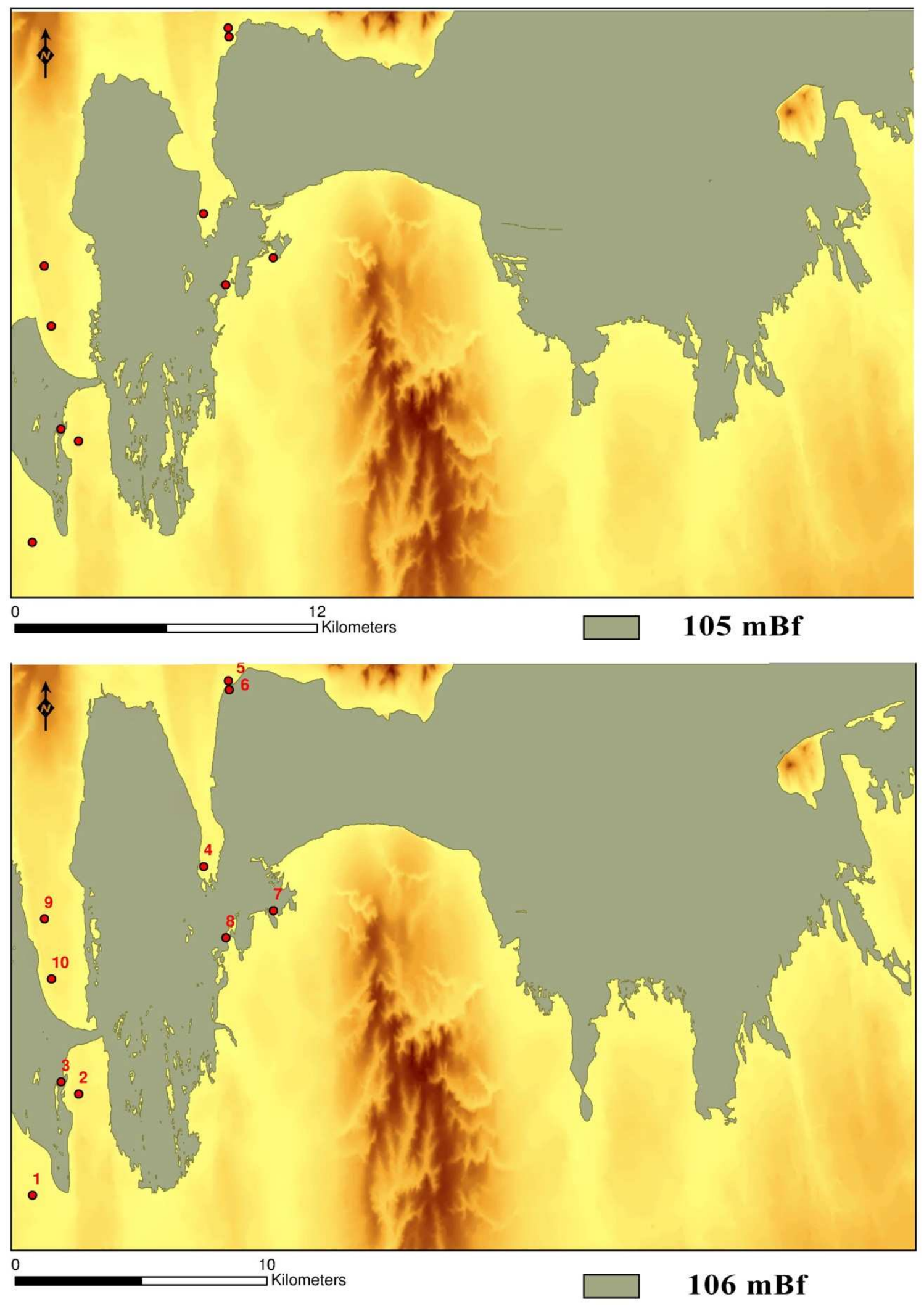

8.3. ábra. A késő neolitikus-kora rézkori Lengyeli kultúra időszakának lelöhelyei: 1. Balatonmagyaród-Fenyves-sziget; 2. Balatonmagyaród-Kiskányavár; 3. BalatonmagyaródSzarkavári-sziget; 4. Keszthely-Halász-rét; 5. Keszthely-Hunyadi utca; 6. Keszthely-Zrínyi utca; 7. Vörs-Battyáni-disznólegelö; 8. Vörs-Kerékerdő; 9. Zalavár; 10 Zalavár-Mekenye 

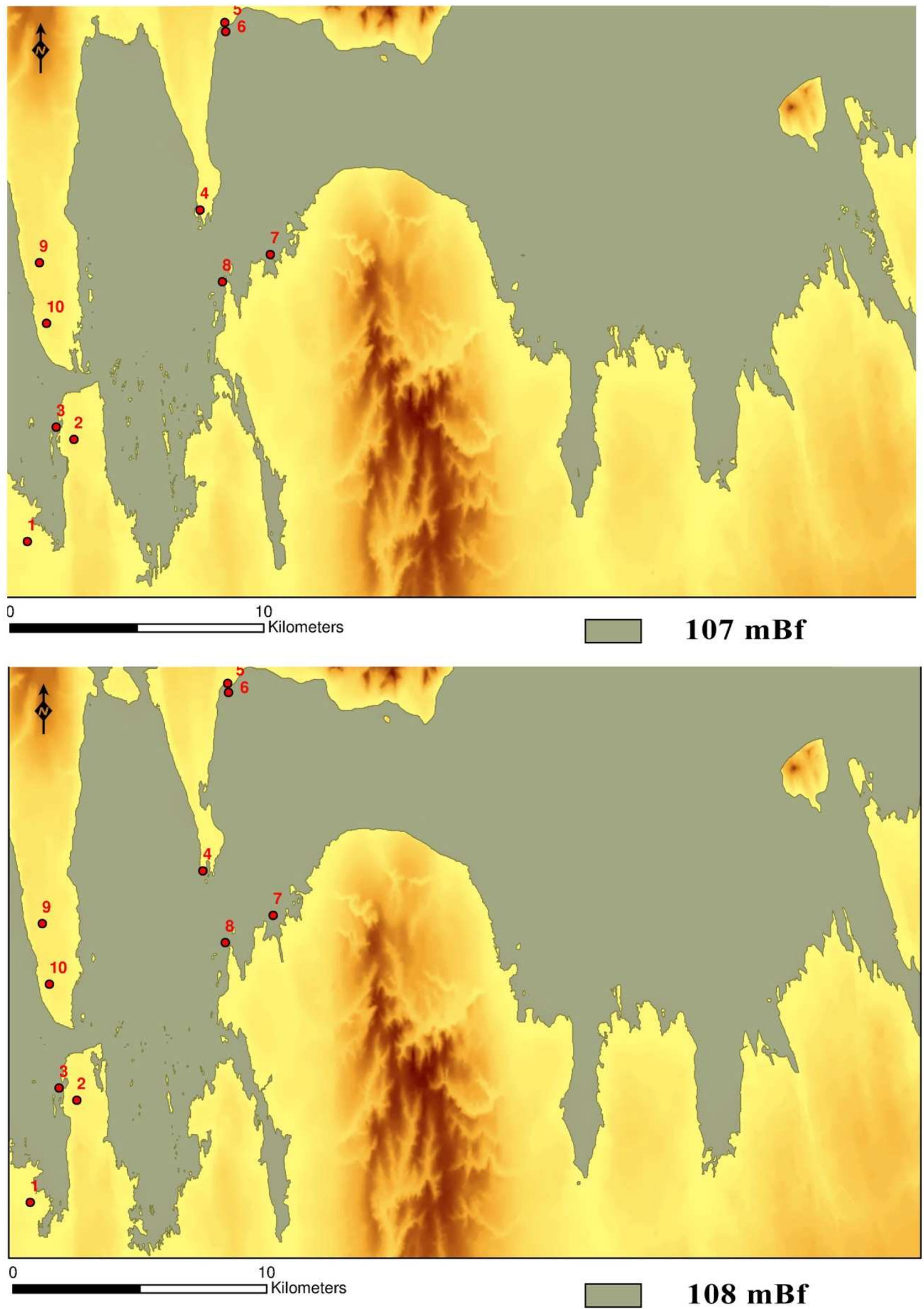

8.4. ábra. A késő neolitikus-kora rézkori Lengyeli kultúra időszakának lelőhelyei: 1. Balatonmagyaród-Fenyves-sziget; 2. Balatonmagyaród-Kiskányavár; 3. BalatonmagyaródSzarkavári-sziget; 4. Keszthely-Halász-rét; 5. Keszthely-Hunyadi utca; 6. Keszthely-Zrínyi utca; 7. Vörs-Battyáni-disznólegelö; 8. Vörs-Kerékerdő; 9. Zalavár; 10 Zalavár-Mekenye 

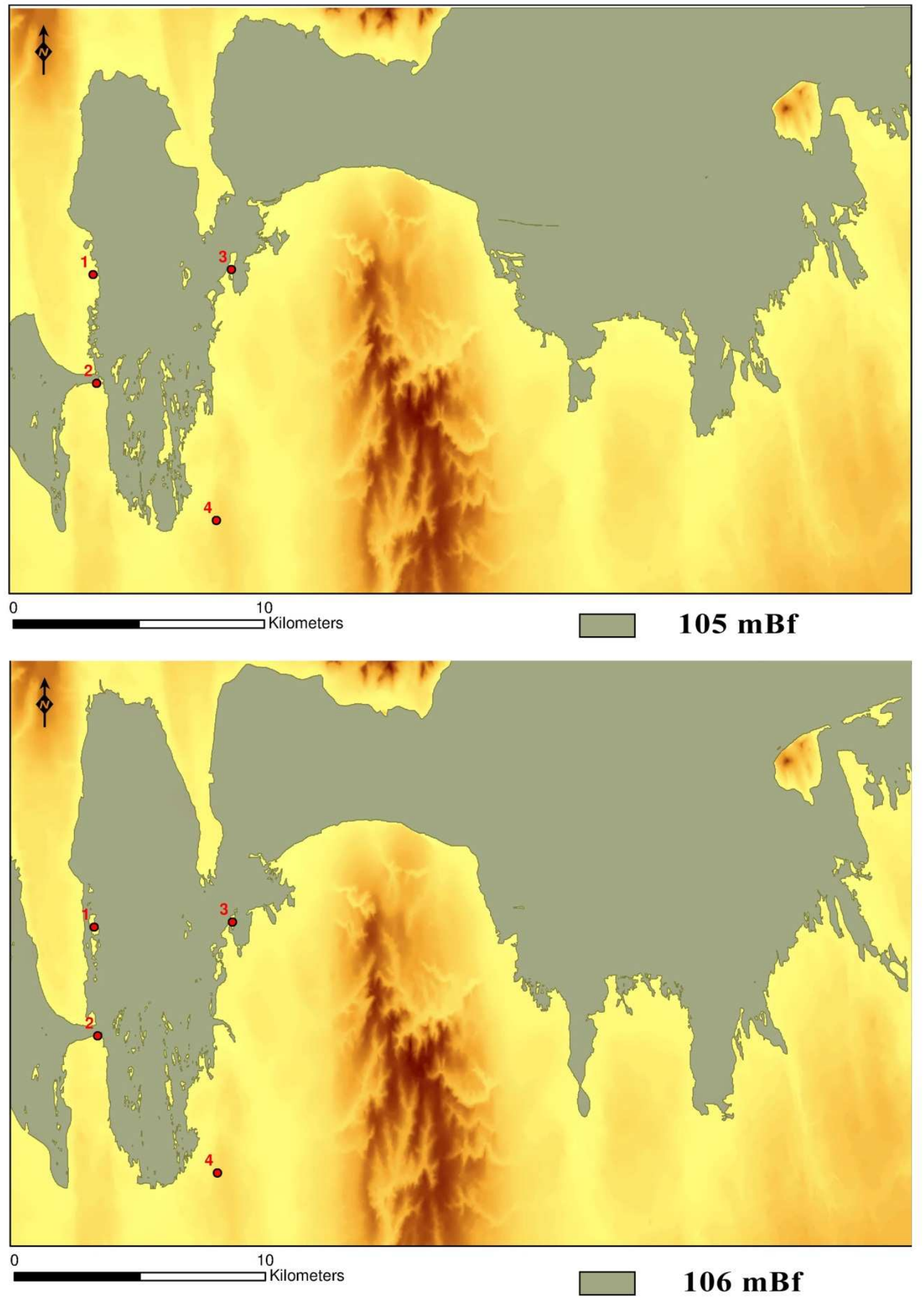

8.5. ábra. A több korszakú neolitikus lelöhelyek: 1. Zalavár-Ökörsziget; 2. BalatonmagyaródHídvégpuszta; 3. Vörs-Máriaaszzony-sziget; 4. Sávoly-Bákos-domb 

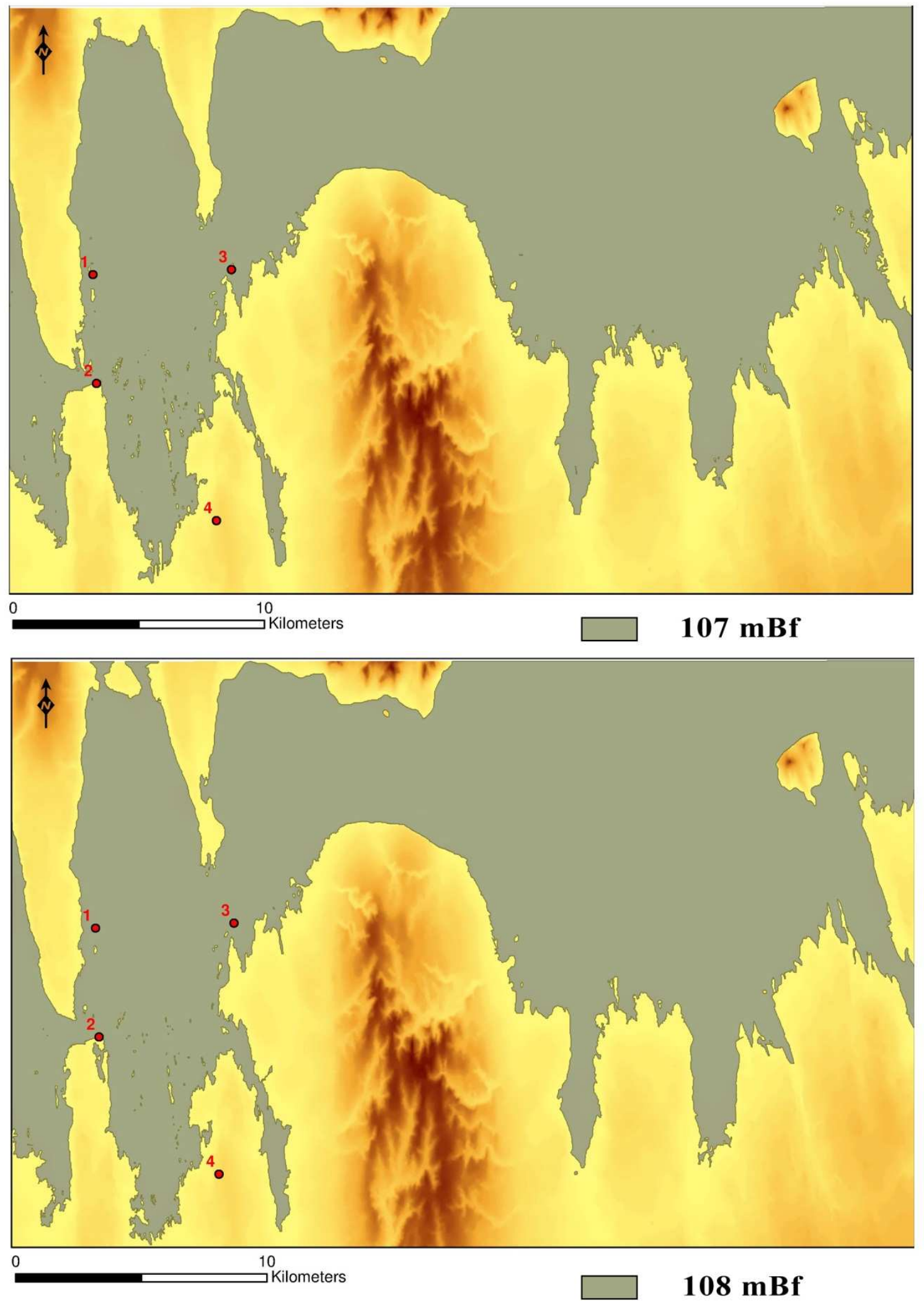

8.6. ábra. A több korszakú neolitikus lelöhelyek: 1. Zalavár-Ökörsziget; 2. BalatonmagyaródHídvégpuszta; 3. Vörs-Máriaaszzony-sziget; 4. Sávoly-Bákos-domb 

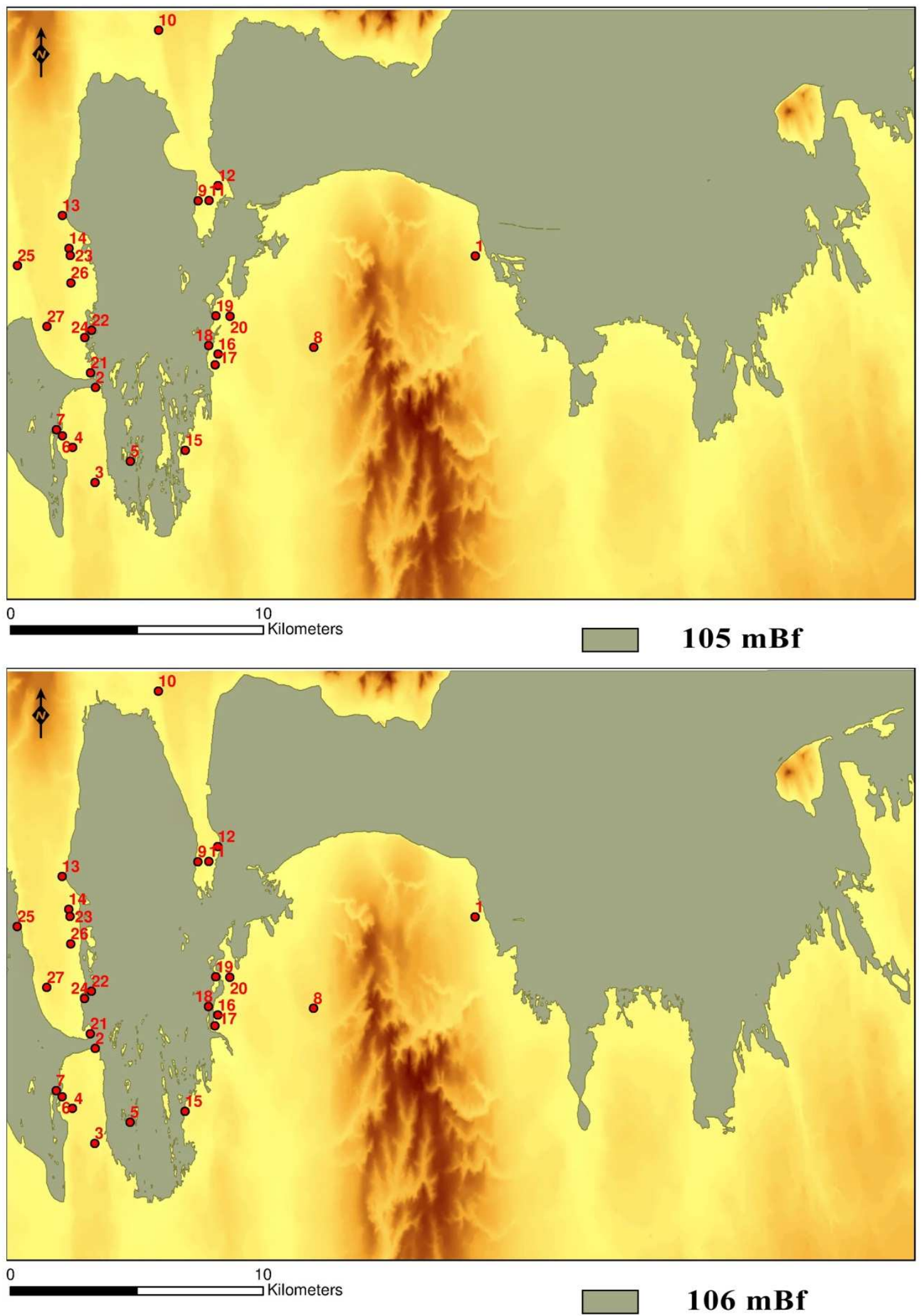

8.7. ábra. A középső rézkori lelőhelyek: 1. Balatonkeresztúr-Réti-dülö; 2. BalatonmagyaródHídvégpuszta; 3. Balatonmagyaród-Homoki-dülö; 4. Balatonmagyaród-Kiskányavár; 5. Balatonmagyaród-Pörköltsziget; 6. Balatonmagyaród-Szarkavári-dülö; 7. BalatonmagyaródSzarkavári-sziget; 8. Balatonszentgyörgy-Almási út; 9. Keszthely-Fenékpuszta-Vízügyi Itp; 10. Keszthely-Gátidomb; 11. Keszthely-Pusztatemplom; 12. Keszthely-Vámház; 13. SármellékAgyagbánya; 14. Sármellék-Zalavári-határárok; 15. Sávoly-Demjéntelep; 16. Vörs-Borzas-dél; 17. Vörs-Kanászkert; 18. Vörs-Nyíres-sziget; 19. Vörs-Papkert B; 20Vörs-Tótok-dombja; 21. Zalavár-Balatonhídvég; 22. Zalavár-Basasziget; 23. Zalavár-Berek; 24. Zalavár-Hídvégi-legelö; 25. Zalavár-Kövecses; 26. Zalavár-Lebujpuszta; 27. Zalavár-Mekenye 

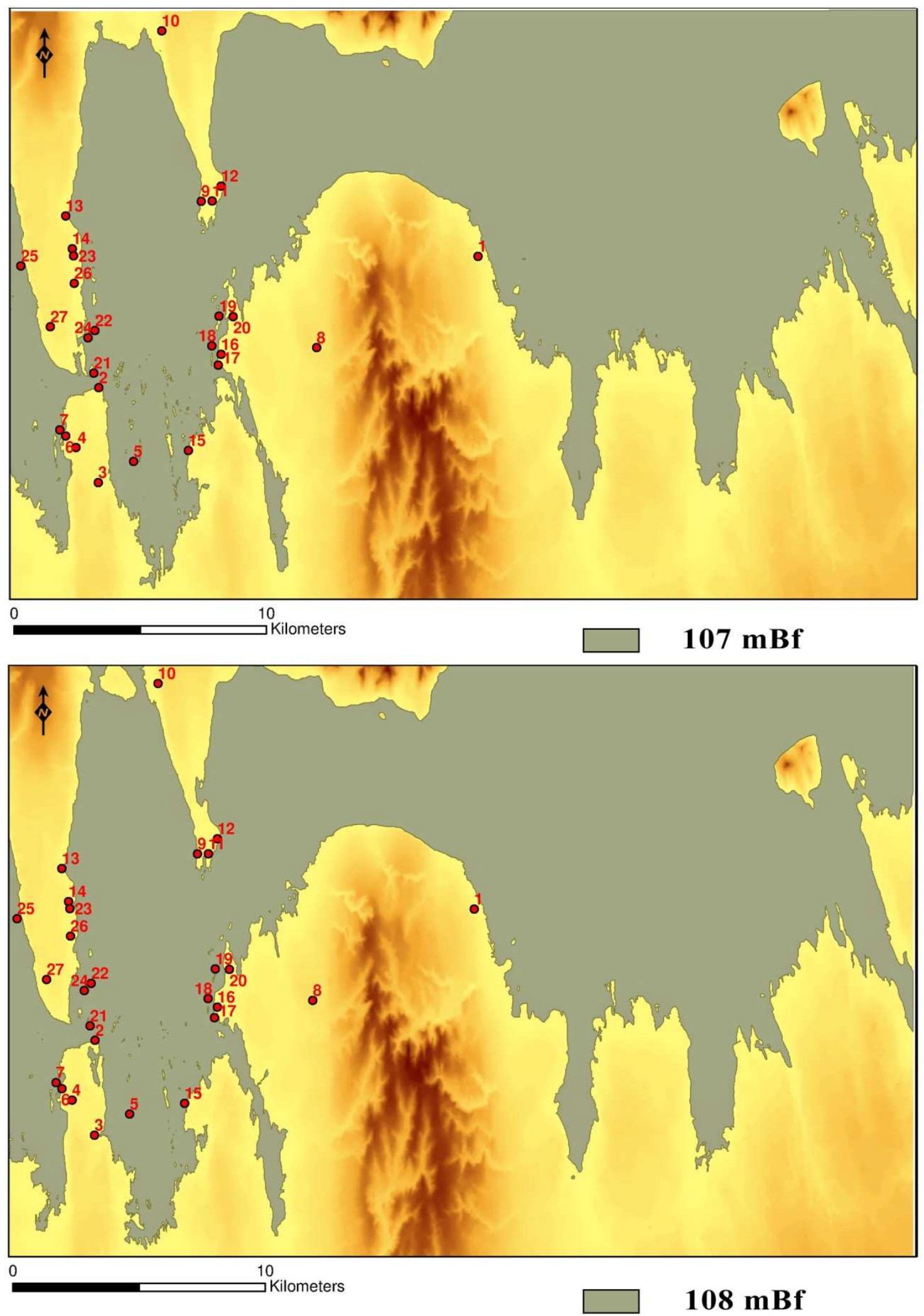

8.8. ábra. A középső rézkori lelőhelyek: 1. Balatonkeresztúr-Réti-dülö; 2. BalatonmagyaródHídvégpuszta; 3. Balatonmagyaród-Homoki-dülö; 4. Balatonmagyaród-Kiskányavár; 5. Balatonmagyaród-Pörköltsziget; 6. Balatonmagyaród-Szarkavári-dúlő; 7. BalatonmagyaródSzarkavári-sziget; 8. Balatonszentgyörgy-Almási út; 9. Keszthely-Fenékpuszta-Vízügyi Itp; 10. Keszthely-Gátidomb; 11. Keszthely-Pusztatemplom; 12. Keszthely-Vámház; 13. SármellékAgyagbánya; 14. Sármellék-Zalavári-határárok; 15. Sávoly-Demjéntelep; 16. Vörs-Borzas-dél; 17. Vörs-Kanászkert; 18. Vörs-Nyíres-sziget; 19. Vörs-Papkert B; 20Vörs-Tótok-dombja; 21. Zalavár-Balatonhídvég; 22. Zalavár-Basasziget; 23. Zalavár-Berek; 24. Zalavár-Hídvégi-legelö; 25. Zalavár-Kövecses; 26. Zalavár-Lebujpuszta; 27. Zalavár-Mekenye 

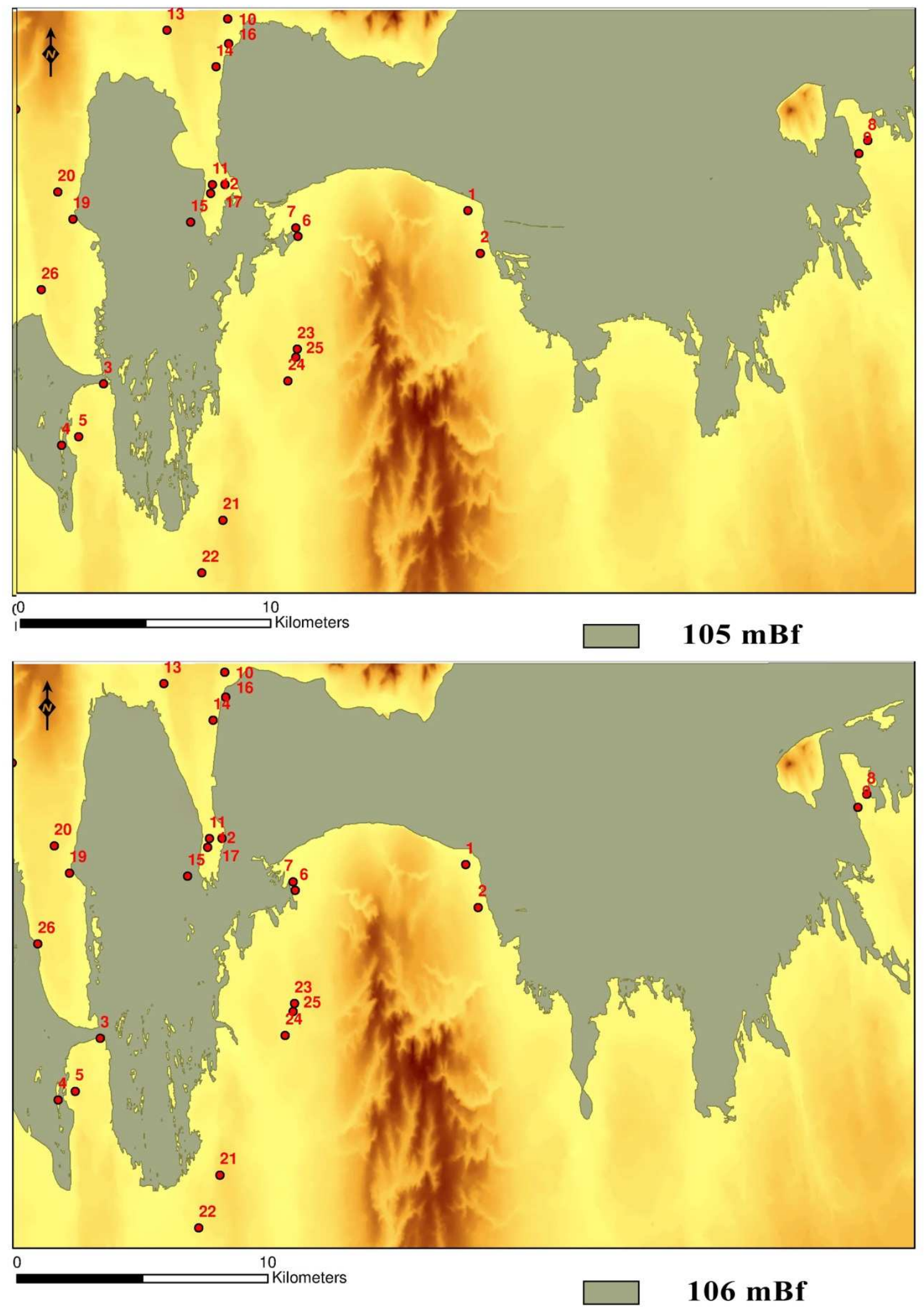

8.9. ábra. A késö rézkori lelöhelyek: 1. Balatonkeresztúr-Csepp utca; 2. Balatonkeresztúr-Rétidülö; 3. Balatonmagyaród-Hídvégpuszta; 4. Balatonmagyaród-Kányavári-sziget; 5. Balatonmagyaród-Kiskányavár; 6. Balatonszentgyörgy-Felüljáró; 7. BalatonszentgyörgyVasútállomás; 8. Fonyód-Bázsenypuszta; 9. Fonyód-Vasúti-dülő; 10. Keszthely-Apát-dpmb; 11. Keszthely-Fenékpuszta; 12. Keszthely-Vasúti-örház; 13. Keszthely-Gáti-domb; 14. KeszthelyHalászcsárda; 15. Keszthely-Hévizi-öböl; 16. Keszthely-Honvéd utca; 17. Keszthely-Vámház; 18. Sármellék-Devecseri-mezö; 19. Sármellék-Égenföld; 20. Sármellék-Zalavári-domb; 21. Sávoly-Bákos-domb; 22. Szőkedencs-Cölömpös-árok; 23. Tikos-Bari-dülö; 24. TikosHomokgödrök; 25. Tikos-Nyárfás-dülö; 26. Zalavár-Iskolaudvar 

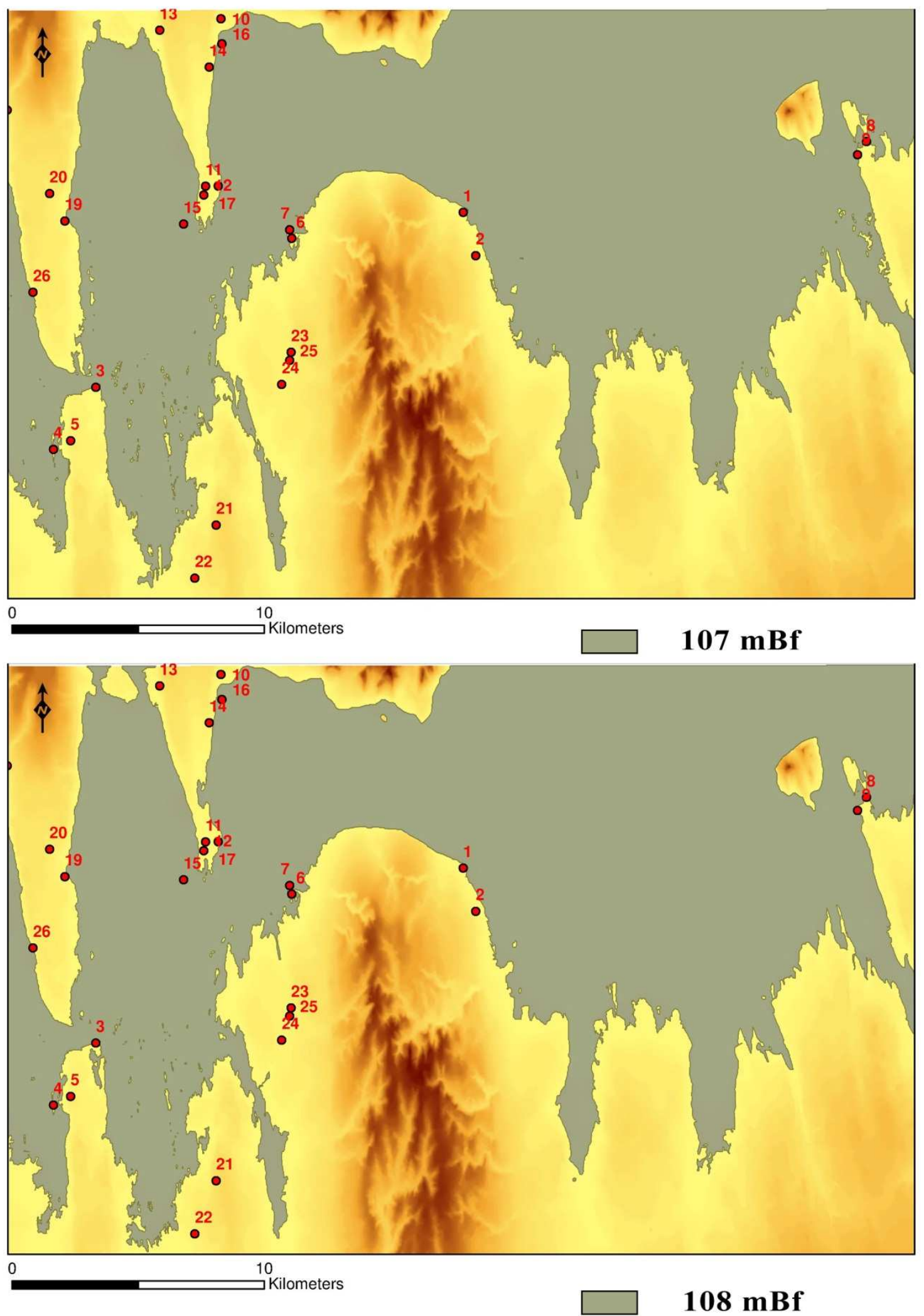

8.10. ábra. A késő rézkori lelöhelyek: 1. Balatonkeresztúr-Csepp utca; 2. BalatonkeresztúrRéti-dülö; 3. Balatonmagyaród-Hídvégpuszta; 4. Balatonmagyaród-Kányavári-sziget; 5. Balatonmagyaród-Kiskányavár; 6. Balatonszentgyörgy-Felüljáró; 7. BalatonszentgyörgyVasútállomás; 8. Fonyód-Bázsenypuszta; 9. Fonyód-Vasúti-dülő; 10. Keszthely-Apát-dpmb; 11. Keszthely-Fenékpuszta; 12. Keszthely-Vasúti-örház; 13. Keszthely-Gáti-domb; 14. KeszthelyHalászcsárda; 15. Keszthely-Hévizi-öböl; 16. Keszthely-Honvéd utca; 17. Keszthely-Vámház; 18. Sármellék-Devecseri-mezö; 19. Sármellék-Égenföld; 20. Sármellék-Zalavári-domb; 21. Sávoly-Bákos-domb; 22. Szökedencs-Cölömpös-árok; 23. Tikos-Bari-dülö; 24. TikosHomokgödrök; 25. Tikos-Nyárfás-dülö; 26. Zalavár-Iskolaudvar 

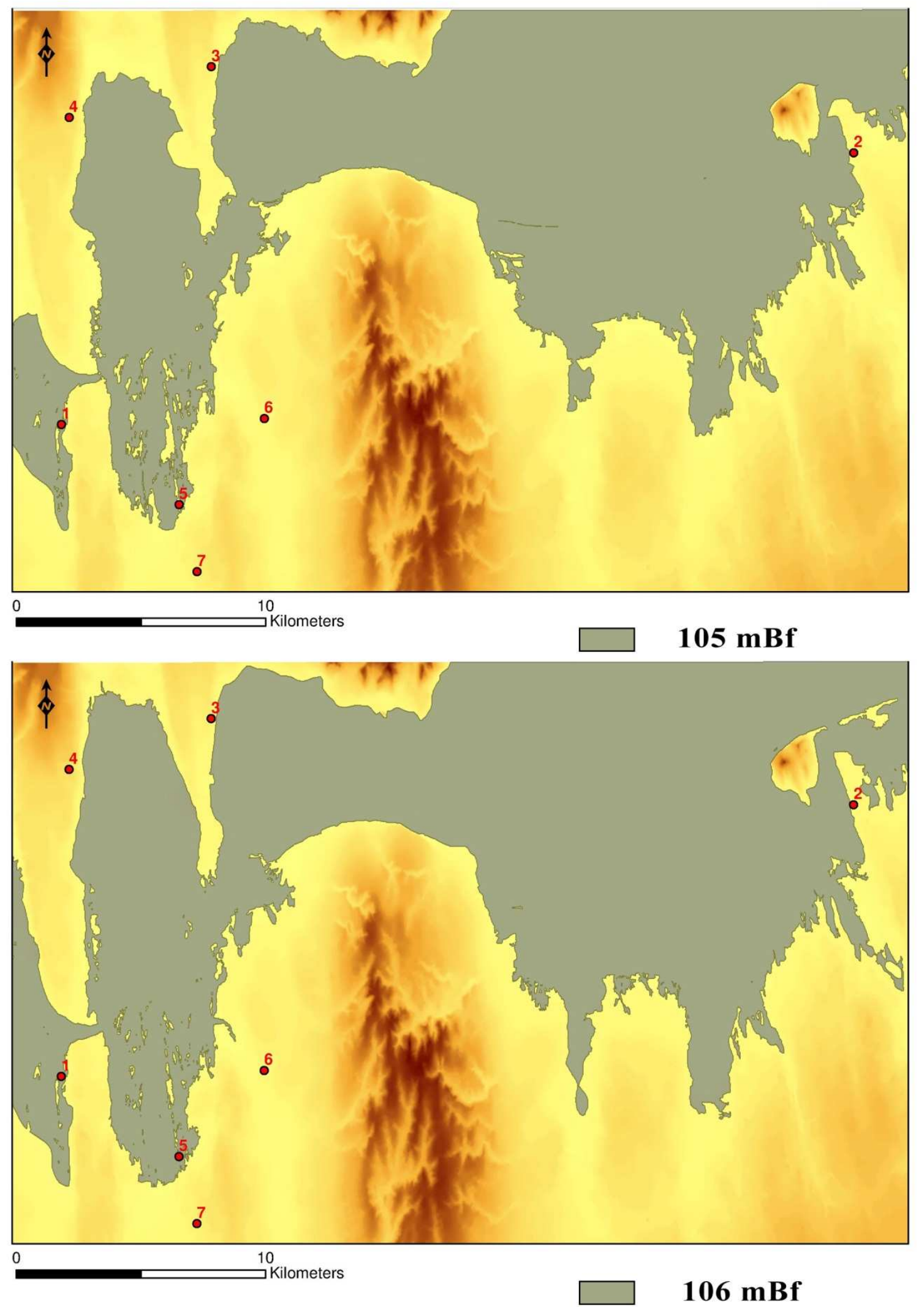

8.11. ábra. A kora bronzkori Somogyvár-Vinkovci kultúra lelöhelyei: 1. BalatonmagyaródSzarkavári-sziget; 2. Fonyód-Vasúti-dülö; 3. Keszthely-Halászcsárda; 4. Sármellék; 5. SávolyNyírfás-sziget; 6. Szegerdő-Legelői-dülö; 7. Szőkedencs-Cölömpös-árok 

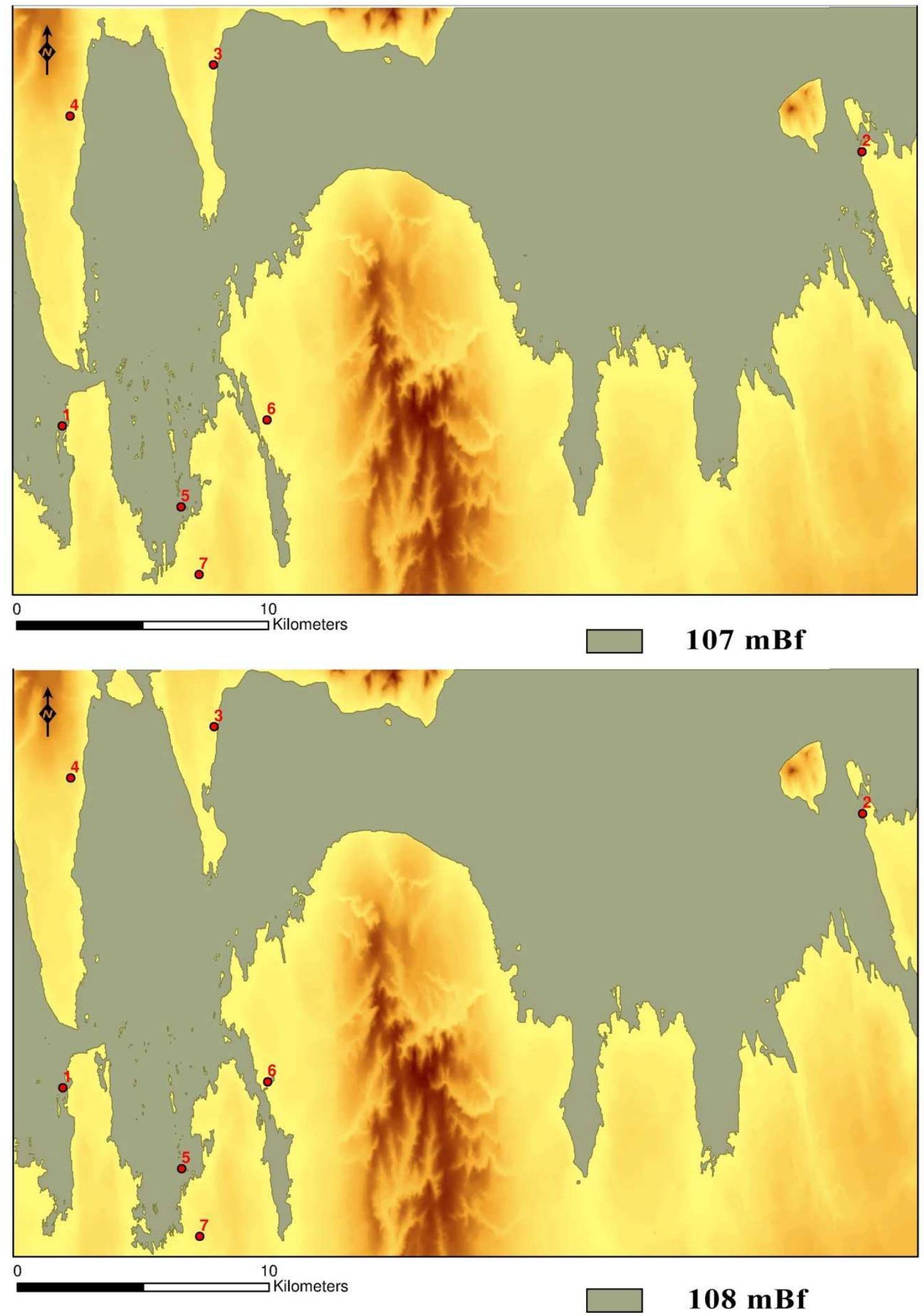

8.12. ábra. A kora bronzkori Somogyvár-Vinkovci kultúra lelöhelyei: 1. BalatonmagyaródSzarkavári-sziget; 2. Fonyód-Vasúti-dülő; 3. Keszthely-Halászcsárda; 4. Sármellék; 5. SávolyNyírfás-sziget; 6. Szegerdö-Legelői-dülö; 7. Szőkedencs-Cölömpös-árok 

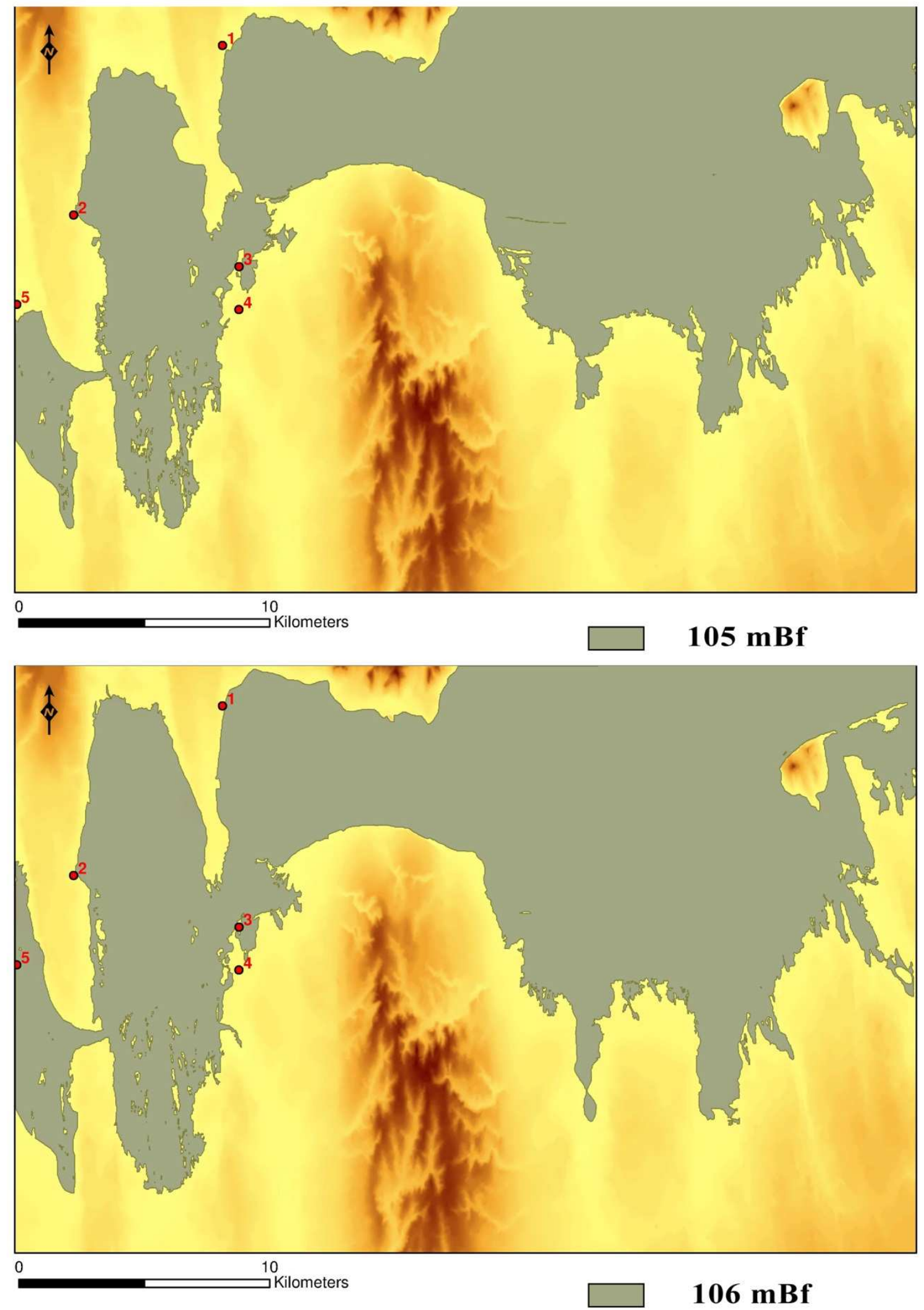

8.13. ábra. A kora bronzkori Kisapostagi kultúra lelöhelyei: 1. Keszthely-Honvéd utca; 2. Sármellék-Égenföld; 3. Vörs-Máriaasszony-sziget; 4. Vörs-Tótok-dombja; 5. Zalavár-Vársziget 

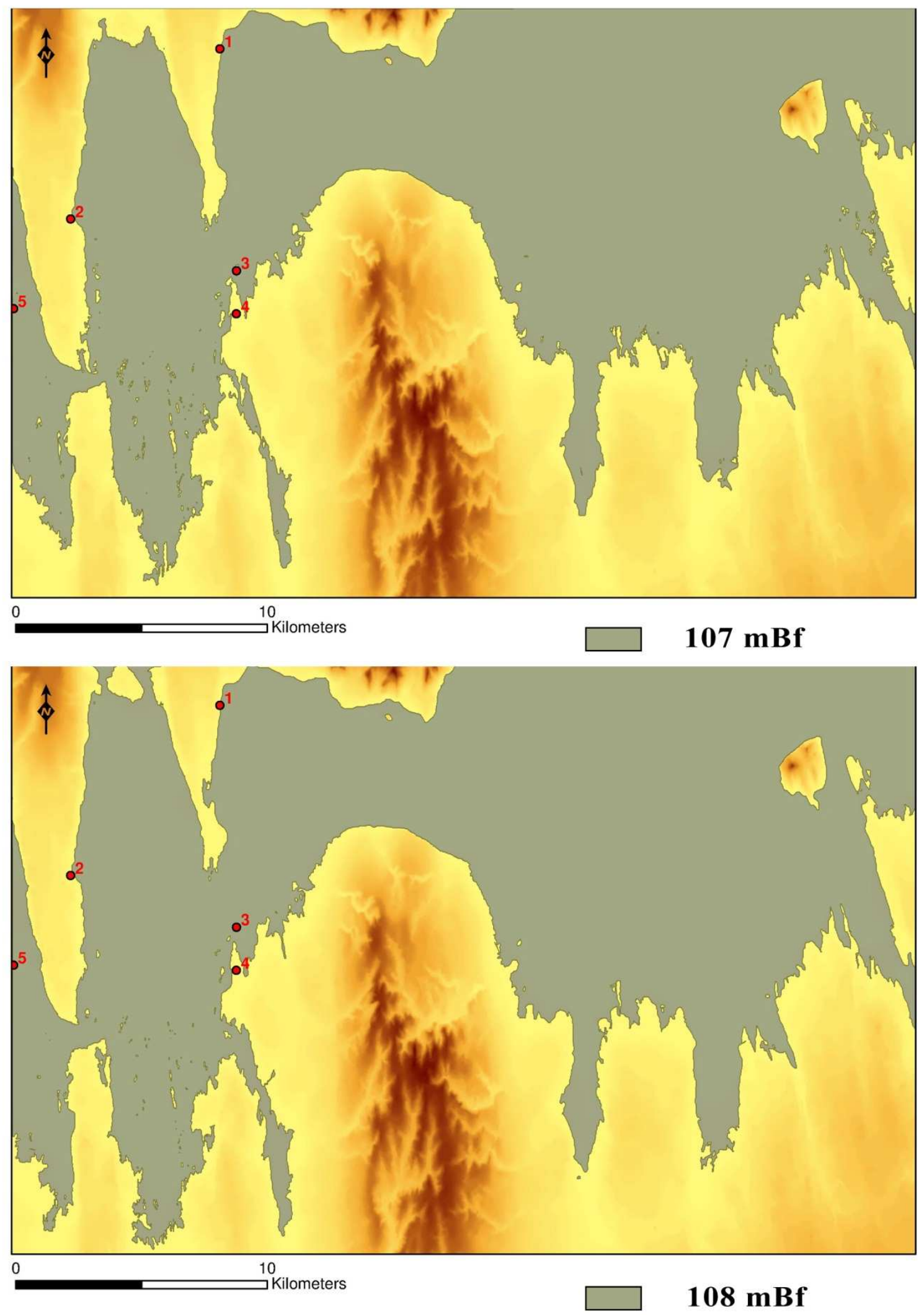

14. ábra. A kora bronzkori Kisapostagi kultúra lelöhelyei: 1. Keszthely-Honvéd utca; 2. Sármellék-Égenföld; 3. Vörs-Máriaasszony-sziget; 4. Vörs-Tótok-dombja; 5. Zalavár-Vársziget 

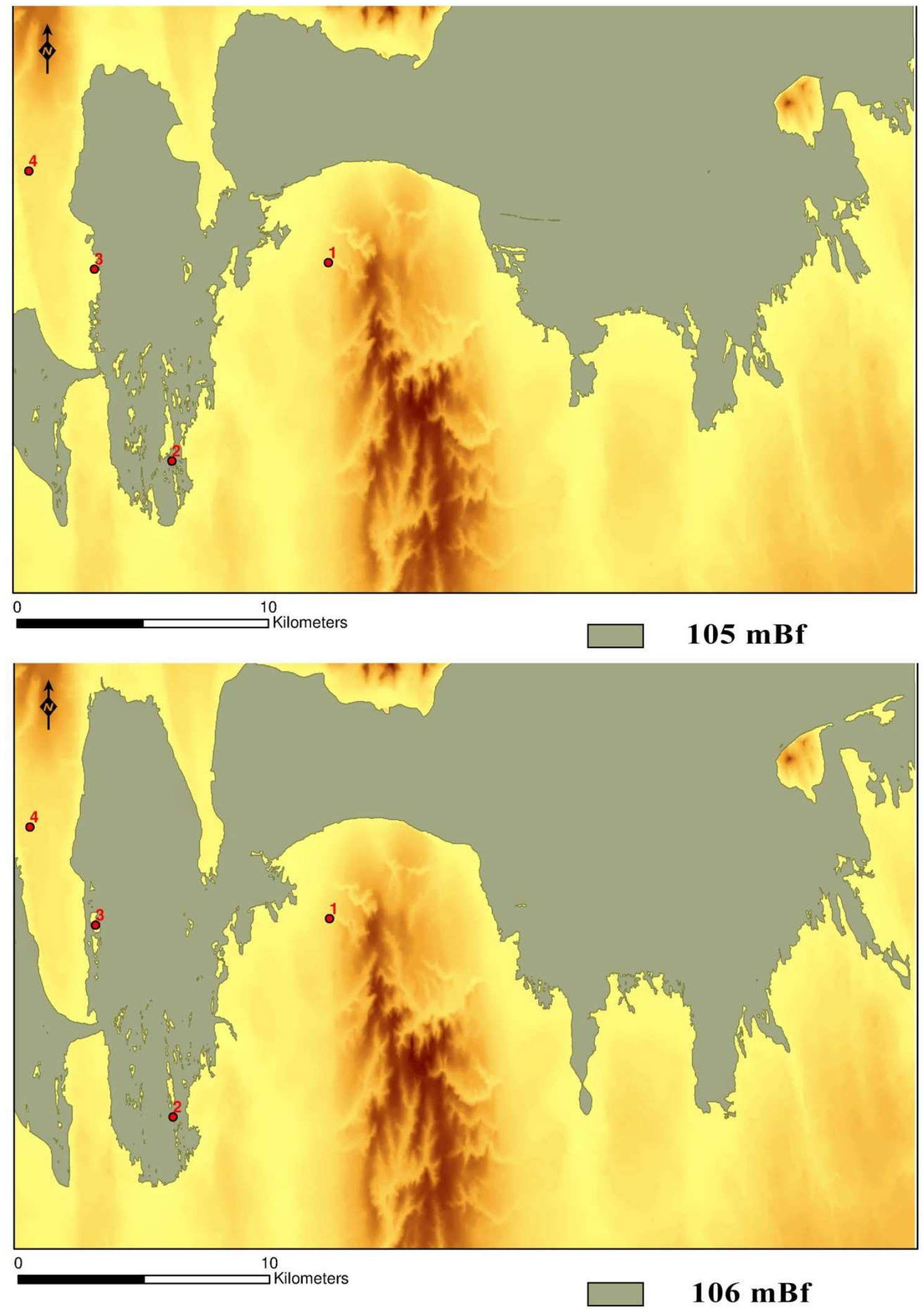

8.15. ábra. A középső bronzkori Mészbetétes Kerámia kultúrájának lelöhelyei: 1. Balatonszentgyörgy-Téglagyár; 2. Sávoly-Fekete-sziget; 3. Zalavár-Ökör-sziget; 4. ZalavárÜrmös-puszta 

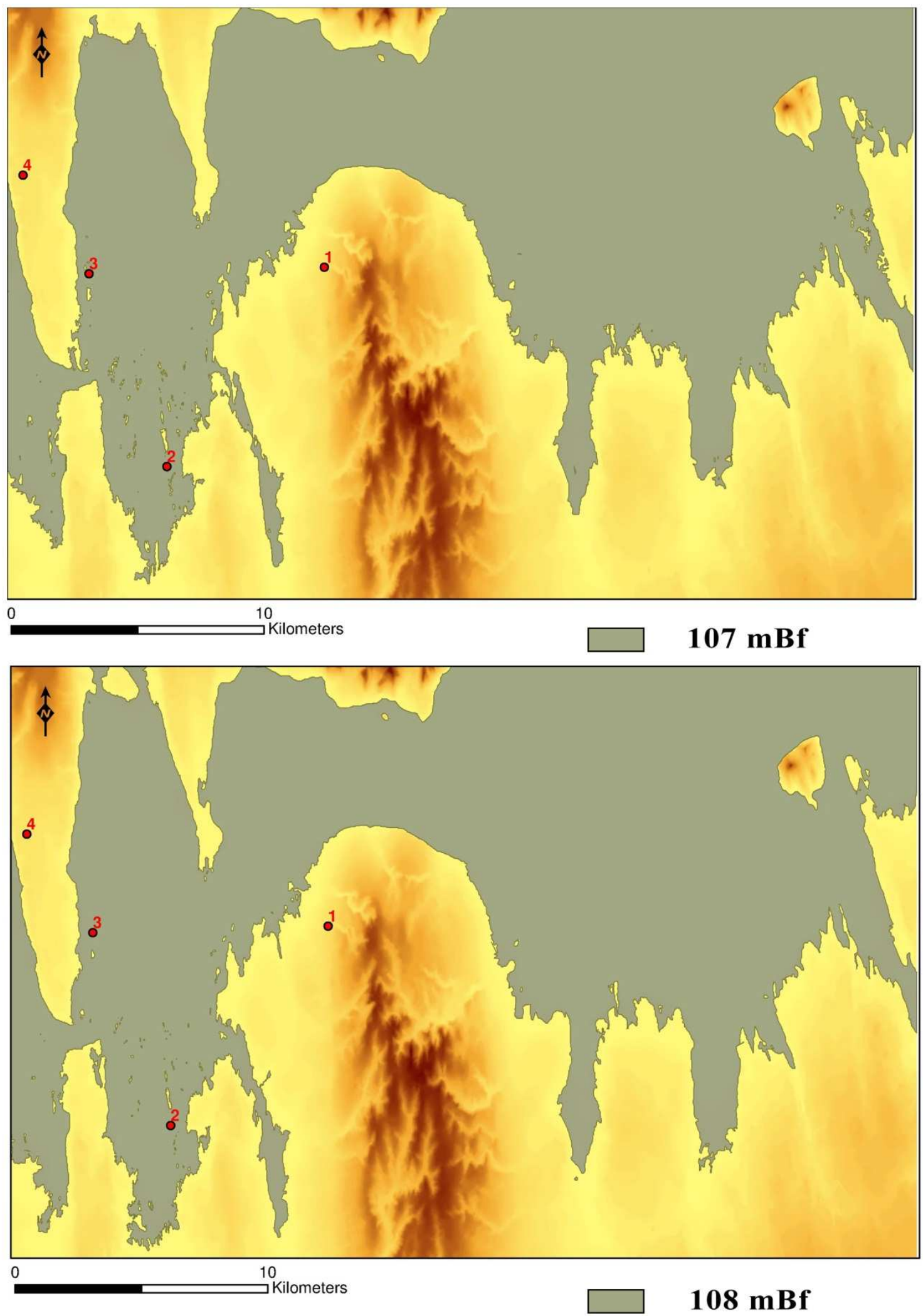

8.16. ábra. A középső bronzkori Mészbetétes Kerámia kultúrájának lelöhelyei: 1. Balatonszentgyörgy-Téglagyár; 2. Sávoly-Fekete-sziget; 3. Zalavár-Ökör-sziget; 4. ZalavárÜrmös-puszta 

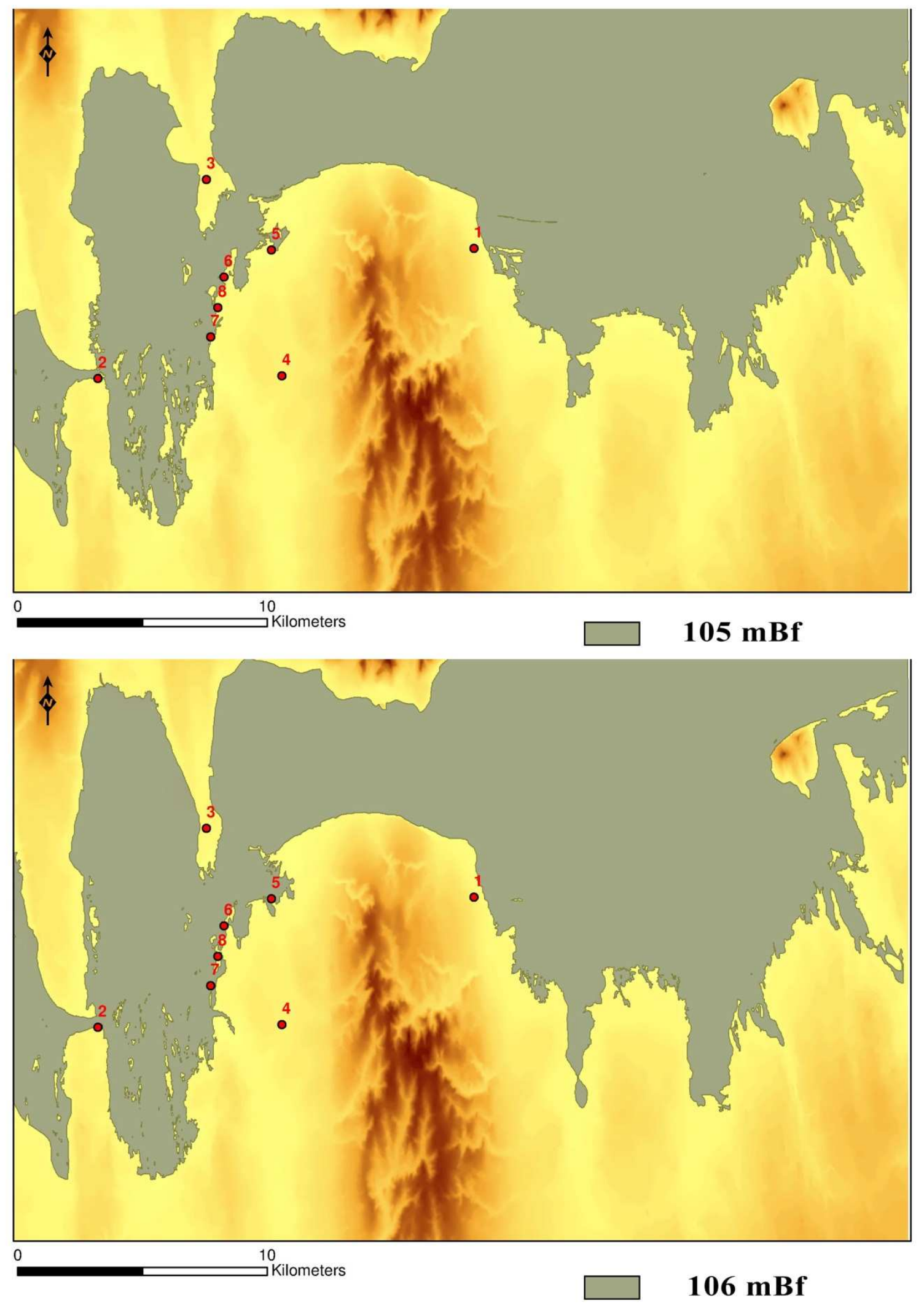

8.17. ábra. A kora és középső bronzkori több korszakú lelöhelyek: 1. Balatonkeresztúr-Rétidülö; 2.Balatonmagyaród-Hídvégpuszta; 3. Keszthely-Fenékpuszta; 4. Tikos-Homokgödrök; 5. Vörs-Battyáni-disznólegelö; 6. Vörs-Kerékerdö; 7. Vörs-Nyíres-sziget; 8. Vörs-Papkert B 

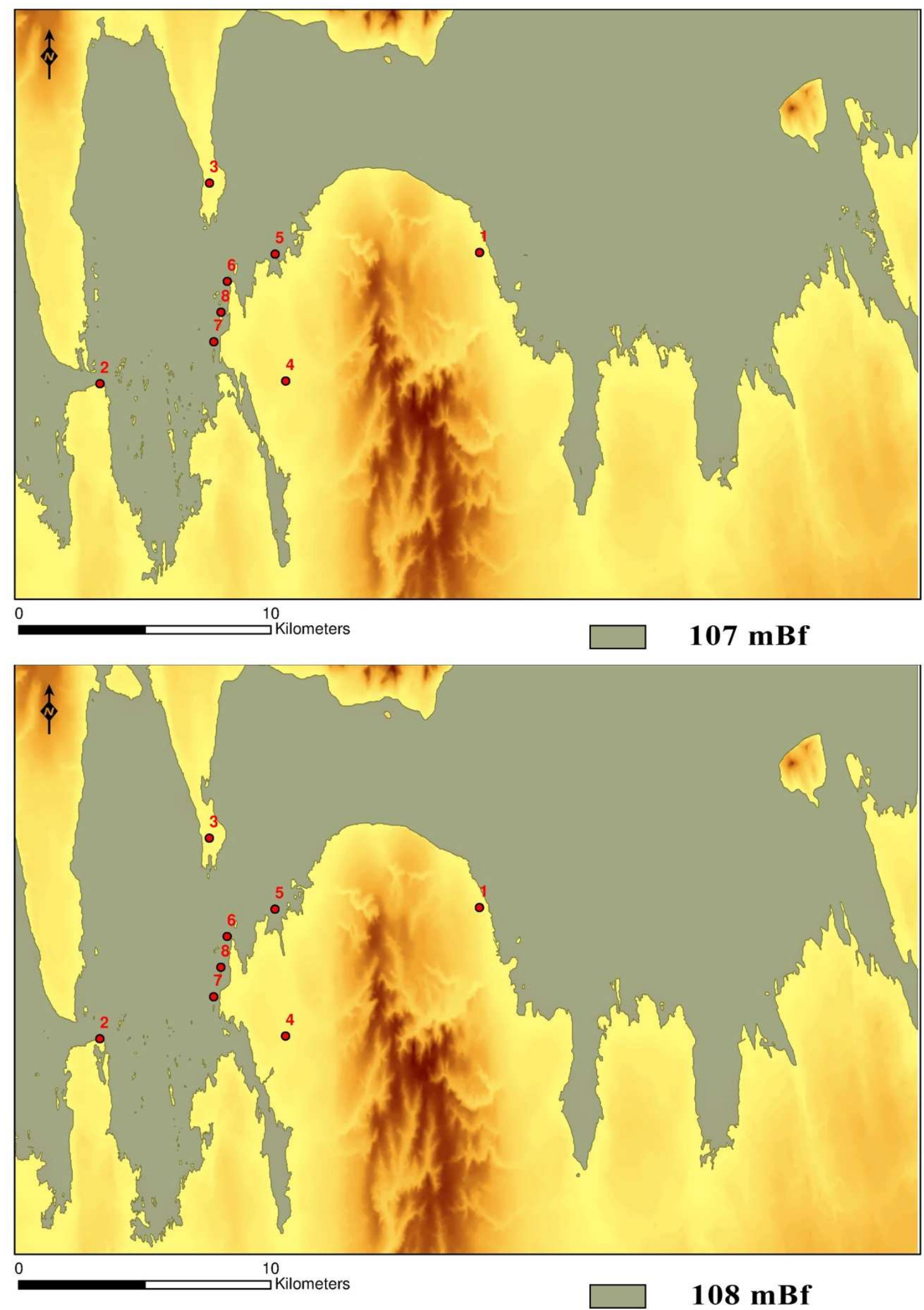

8.18. ábra. A kora és középső bronzkori több korszakú lelöhelyek: 1. Balatonkeresztúr-Rétidülö; 2.Balatonmagyaród-Hídvégpuszta; 3. Keszthely-Fenékpuszta; 4. Tikos-Homokgödrök; 5. Vörs-Battyáni-disznólegelö; 6. Vörs-Kerékerdö; 7. Vörs-Nyíres-sziget; 8. Vörs-Papkert B 

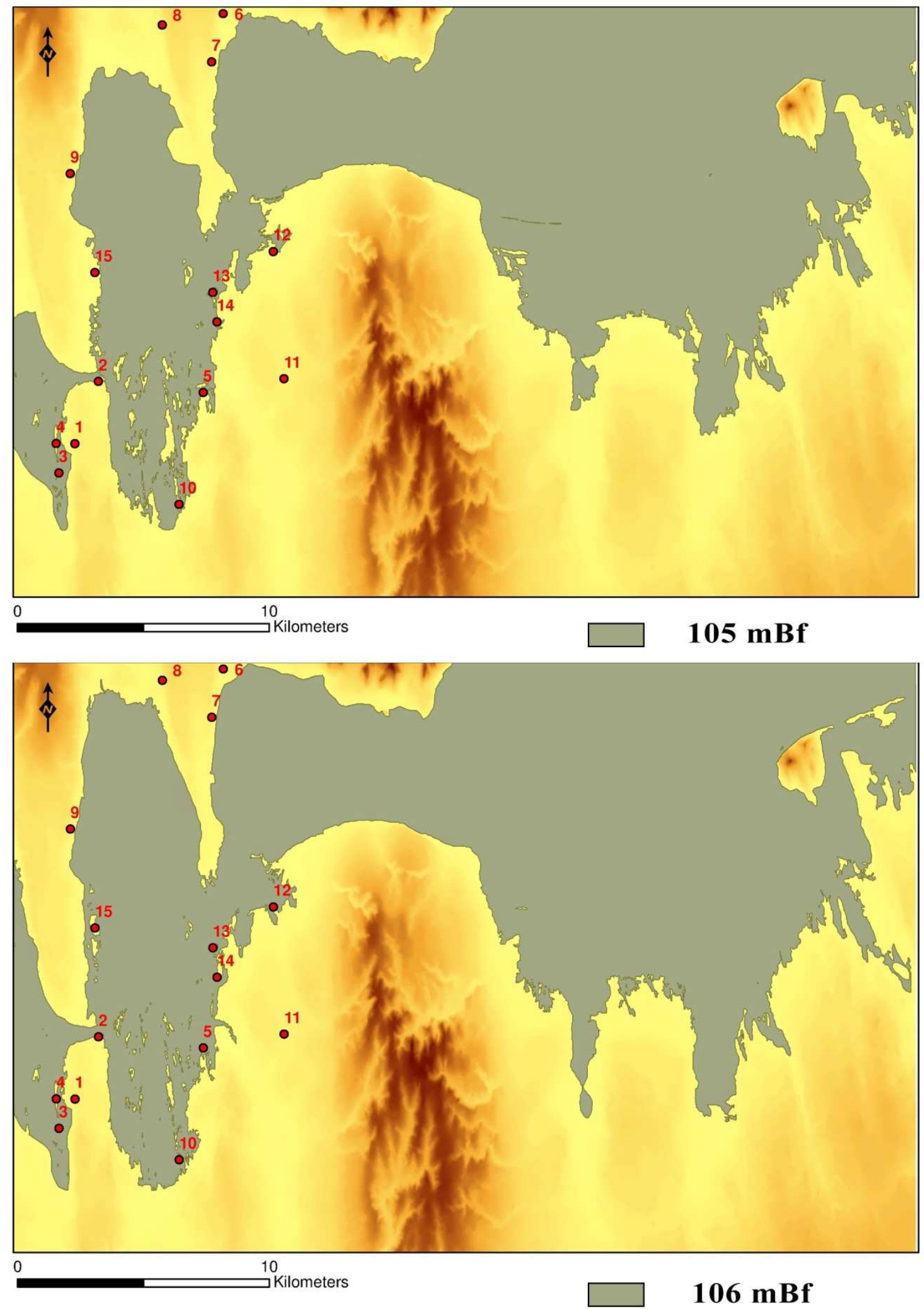

8.19. ábra. A késő bronzkori lelöhelyek: 1. Balatonmagyaród-Kiskányavár; 2. Balatonmagyaród-Hídvégpuszta; 3. Balatonmagyaród-Brúner-sziget; 4. BalatonmagyaródKányavári-sziget; 5. Fönyed-Gólyásfa; 6. Keszthely-Apát-domb; 7. Keszthely-Halászcsárda; 8. Keszthely-Úsztató; 9. Sármellék-Bekötőút; 10. Sávply-Nyírfás-sziget; 11. Tikos-Homokgödrök; 12. Vörs-Battyáni-disznólegelö; 13. Vörs-Papkert A; 14. Vörs-Papkert B; 15. Zalavár-Ökörsziget 

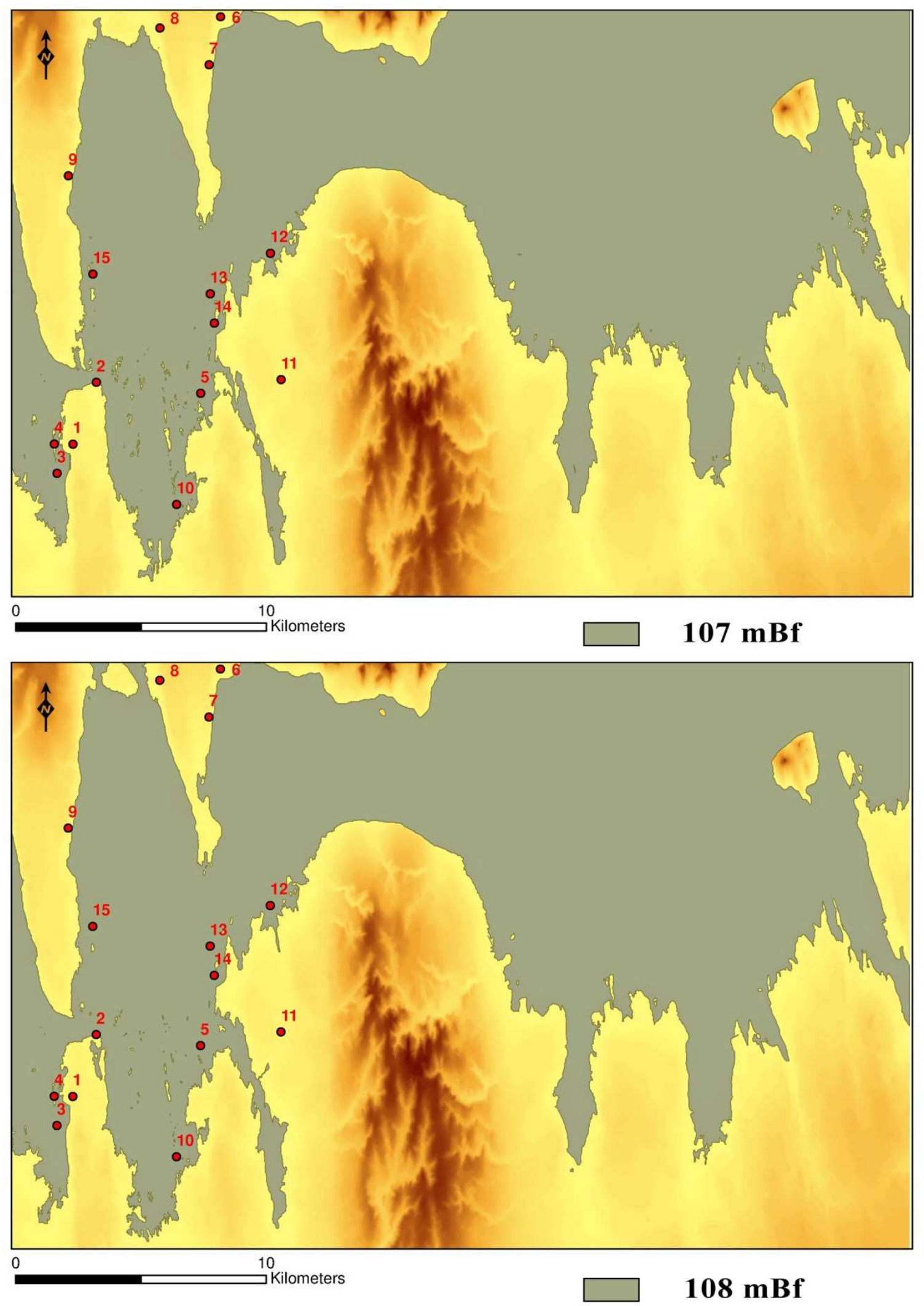

8.20. ábra. A késő bronzkori lelöhelyek: 1. Balatonmagyaród-Kiskányavár; 2. Balatonmagyaród-Hídvégpuszta; 3. Balatonmagyaród-Brúner-sziget; 4. BalatonmagyaródKányavári-sziget; 5. Fönyed-Gólyásfa; 6. Keszthely-Apát-domb; 7. Keszthely-Halászcsárda; 8. Keszthely-Úsztató; 9. Sármellék-Bekötőút; 10. Sávply-Nyírfás-sziget; 11. Tikos-Homokgödrök; 12. Vörs-Battyáni-disznólegelö; 13. Vörs-Papkert A; 14. Vörs-Papkert B; 15. Zalavár-Ökörsziget 

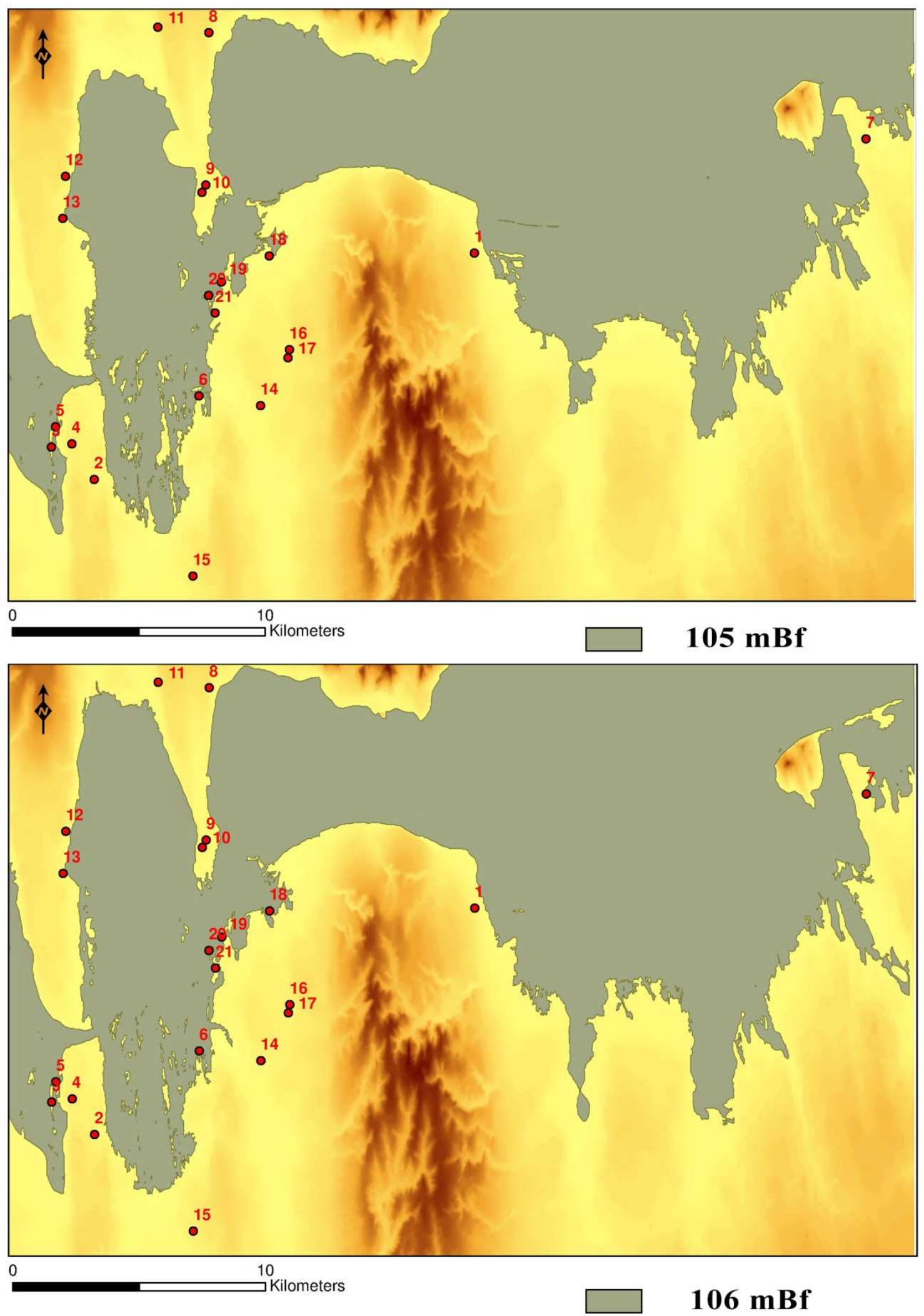

8.21. ábra. A késő vaskori lelőhelyek: 1. Balatonkeresztúr-Réti-dülő; 2. BalatonmagyaródHomoki-dülö; 3. Balatonmagyaród-Kányavári-sziget; 4. Balatonmagyaród-Kiskányavár; 5. Balatonmagyaród-Szarkavári-sziget; 6. Fönyed-Gólyásfa; 7. Fonyód-Bézseny-puszta; 8. Keszthely-Belterület; 9. Keszthely-Fenékpuszta; 10. Keszthely-Vasúti-őrház; 11. KeszthelyÚsztató; 12. Sármellék-Bekötőút; 13. Sármellék-Égenföld; 14. Szegerdö-Marótvölgyi-csatorna; 15. Szőkedencs-Cölömpös-árok; 16. Tikos-Bari-dülö; 17. Tikos-Nyárfás-dülö; 18. VörsBattyáni-disznólegelő; 19. Vörs-Kerékerdő; 20. Vörs-Papkert A; 21. Vörs-Papkert B 

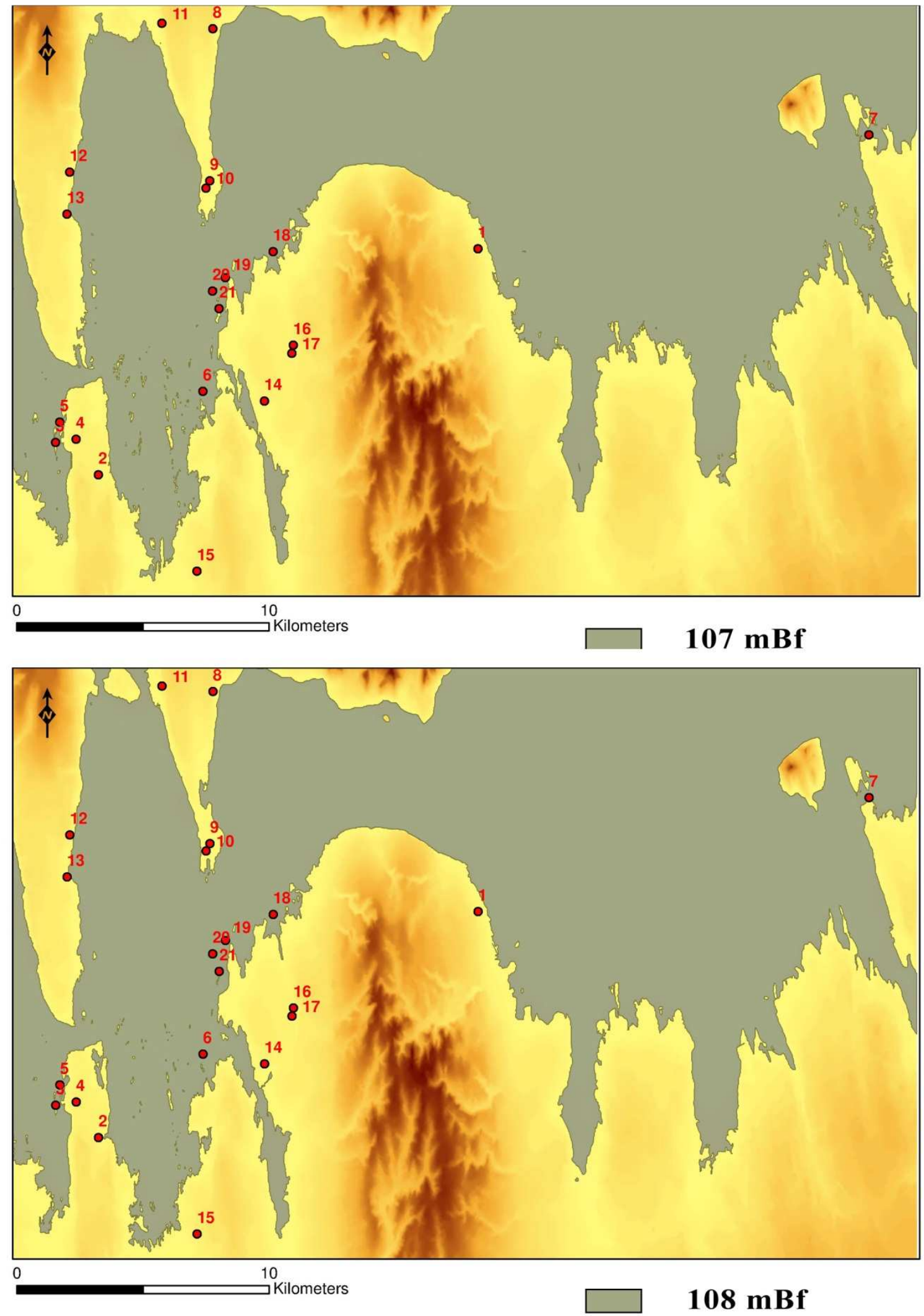

8.22. ábra. A késő vaskori lelöhelyek: 1. Balatonkeresztúr-Réti-dülö; 2. BalatonmagyaródHomoki-dülö; 3. Balatonmagyaród-Kányavári-sziget; 4. Balatonmagyaród-Kiskányavár; 5. Balatonmagyaród-Szarkavári-sziget; 6. Fönyed-Gólyásfa; 7. Fonyód-Bézseny-puszta; 8. Keszthely-Belterület; 9. Keszthely-Fenékpuszta; 10. Keszthely-Vasúti-örház; 11. KeszthelyÚsztató; 12. Sármellék-Bekötőút; 13. Sármellék-Égenföld; 14. Szegerdö-Marótvölgyi-csatorna; 15. Szökedencs-Cölömpös-árok; 16. Tikos-Bari-dülö; 17. Tikos-Nyárfás-dülö; 18. VörsBattyáni-disznólegelö; 19. Vörs-Kerékerdő; 20. Vörs-Papkert A; 21. Vörs-Papkert B 

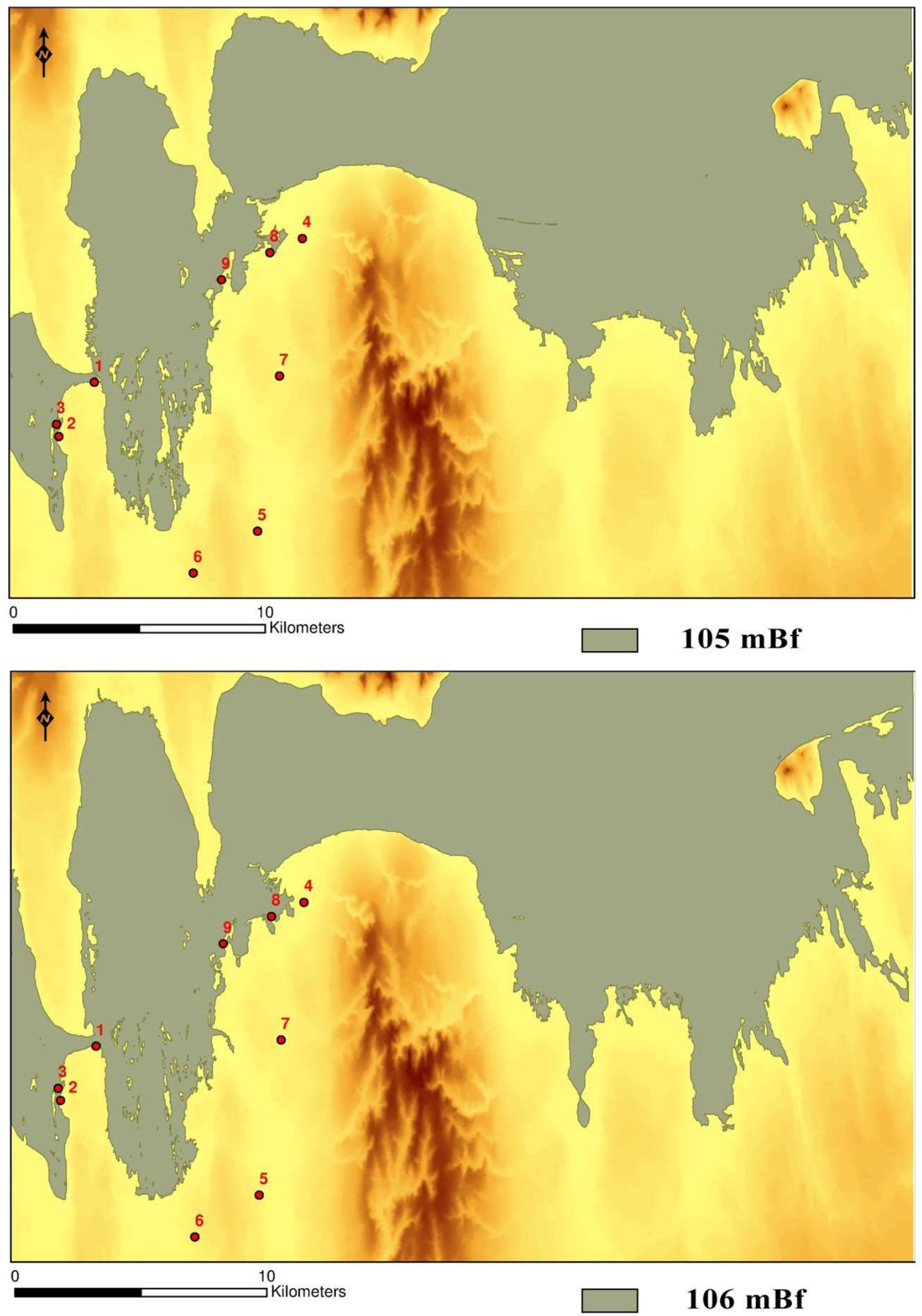

8.23. ábra. A római kori bennszülött települések: 1. Balatonmagyaród-Hídvégpuszta; 2. Balatonmagyaród-Szarkavári-dülö; 3. Balatonmagyaród-Szarkavári-sziget; 4. Balatonszentgyörgy-Új utca; 5. Sávoly-Szigeti-dülö; 6. Szökedencs-Cölömpös-árok; 7. TikosHomokgödrök; 8. Vörs-Battyáni-disznólegelö; 9. Vörs-Kerékerdö 

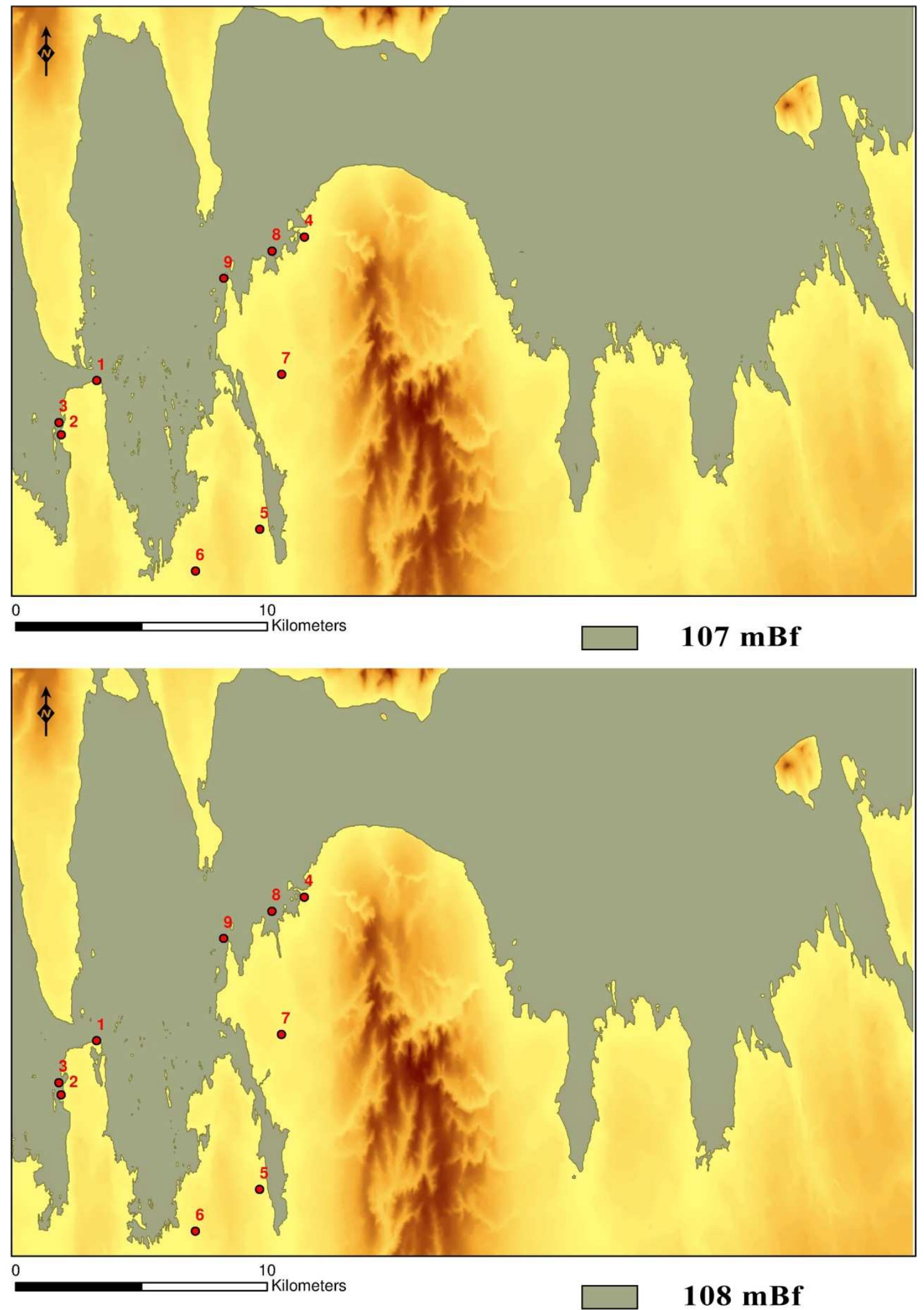

8.24. ábra. A római kori bennszülött települések: 1. Balatonmagyaród-Hídvégpuszta; 2.

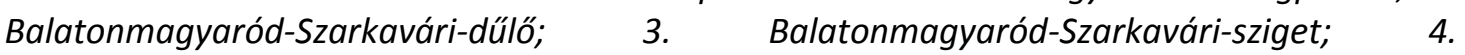
Balatonszentgyörgy-Új utca; 5. Sávoly-Szigeti-dülö; 6. Szőkedencs-Cölömpös-árok; 7. TikosHomokgödrök; 8. Vörs-Battyáni-disznólegelö; 9. Vörs-Kerékerdő 

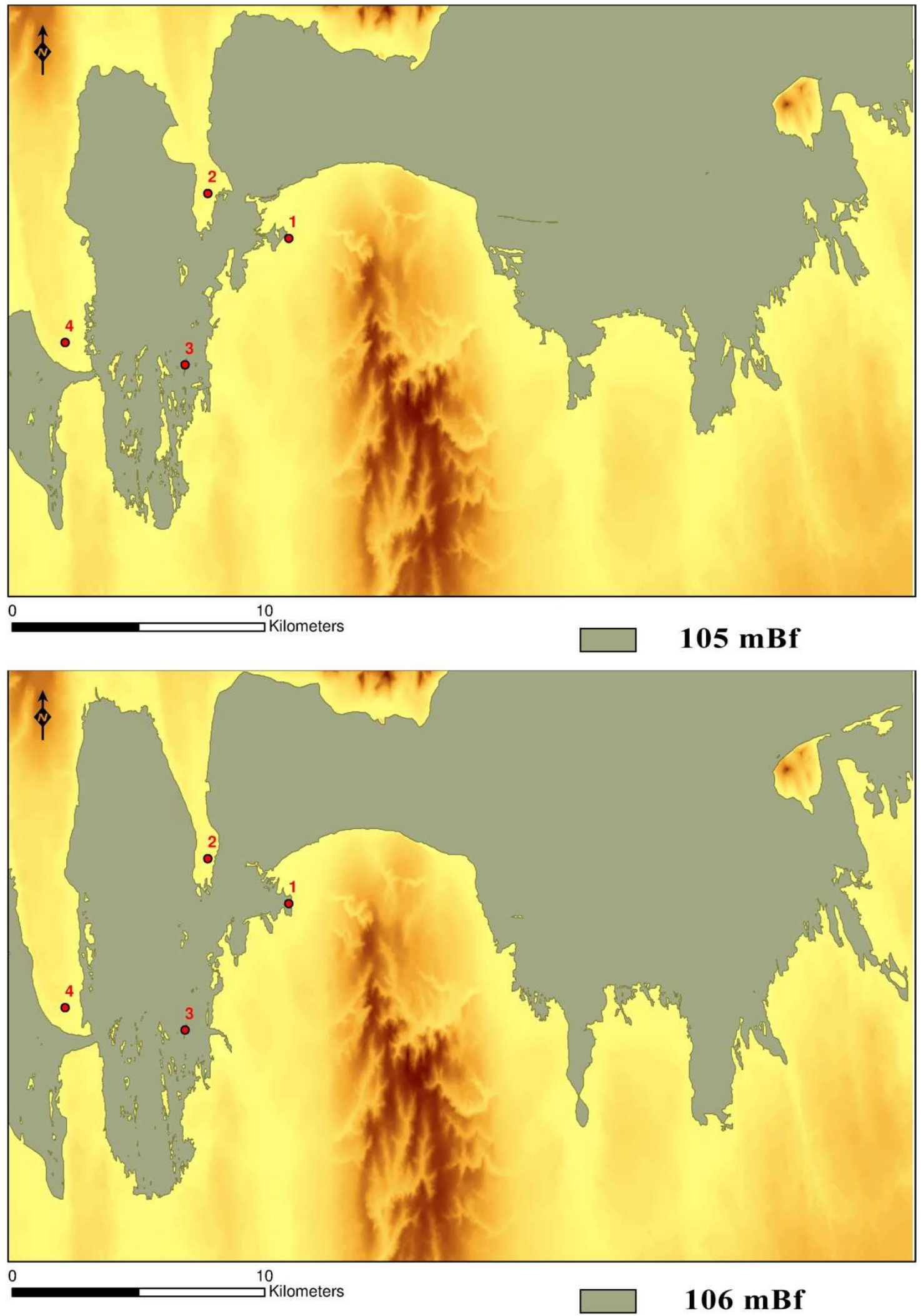

8.25. ábra. kora római kö és téglaépítmények: 1. Balatonszentgyörgy; 2. KeszthelyPusztatemplom; 3. Vörs-Pogány-sziget; 4. Zalavár-Nedám. 

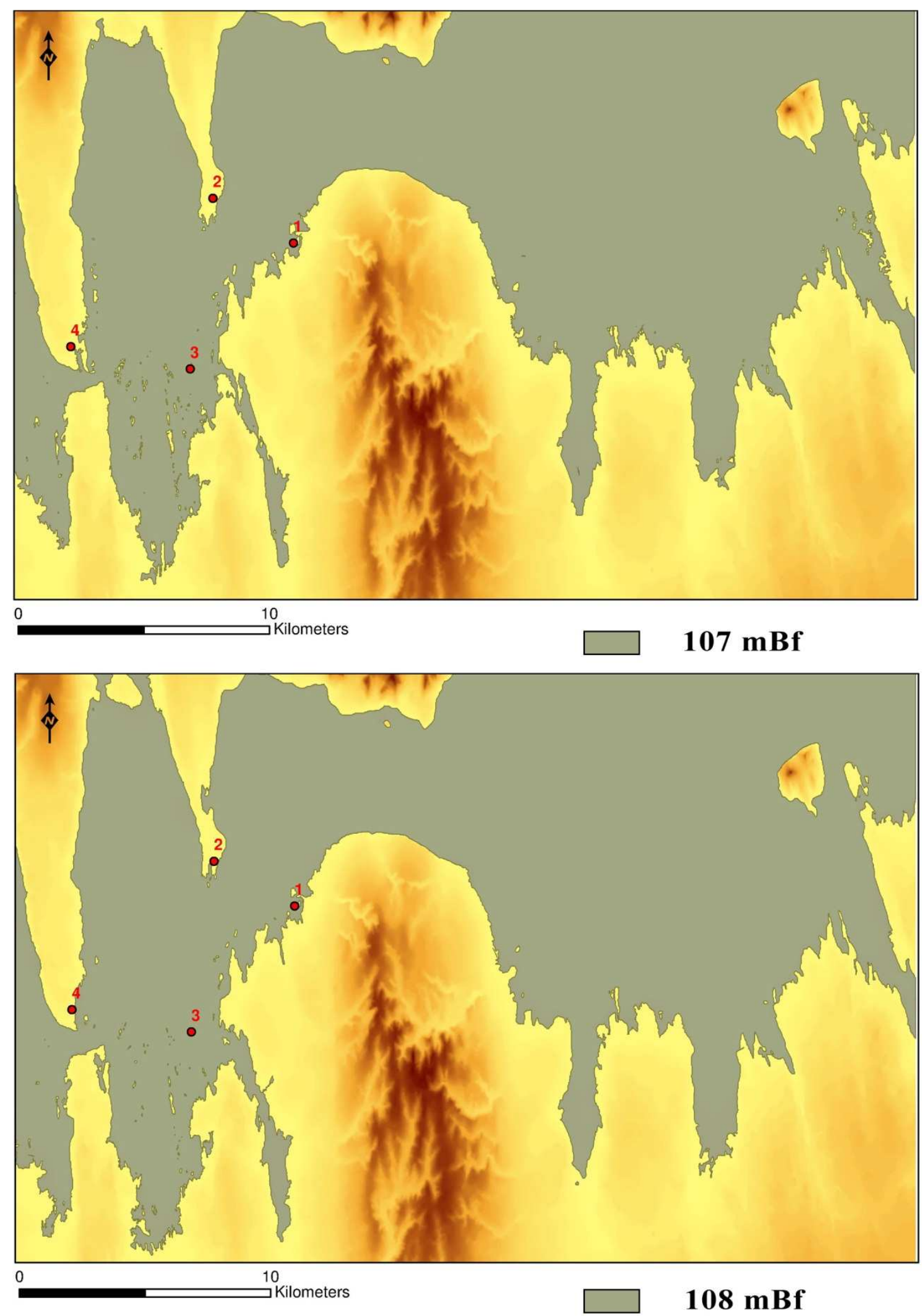

8.26. ábra. kora római kö és téglaépítmények: 1. Balatonszentgyörgy; 2. KeszthelyPusztatemplom; 3. Vörs-Pogány-sziget; 4. Zalavár-Nedám 

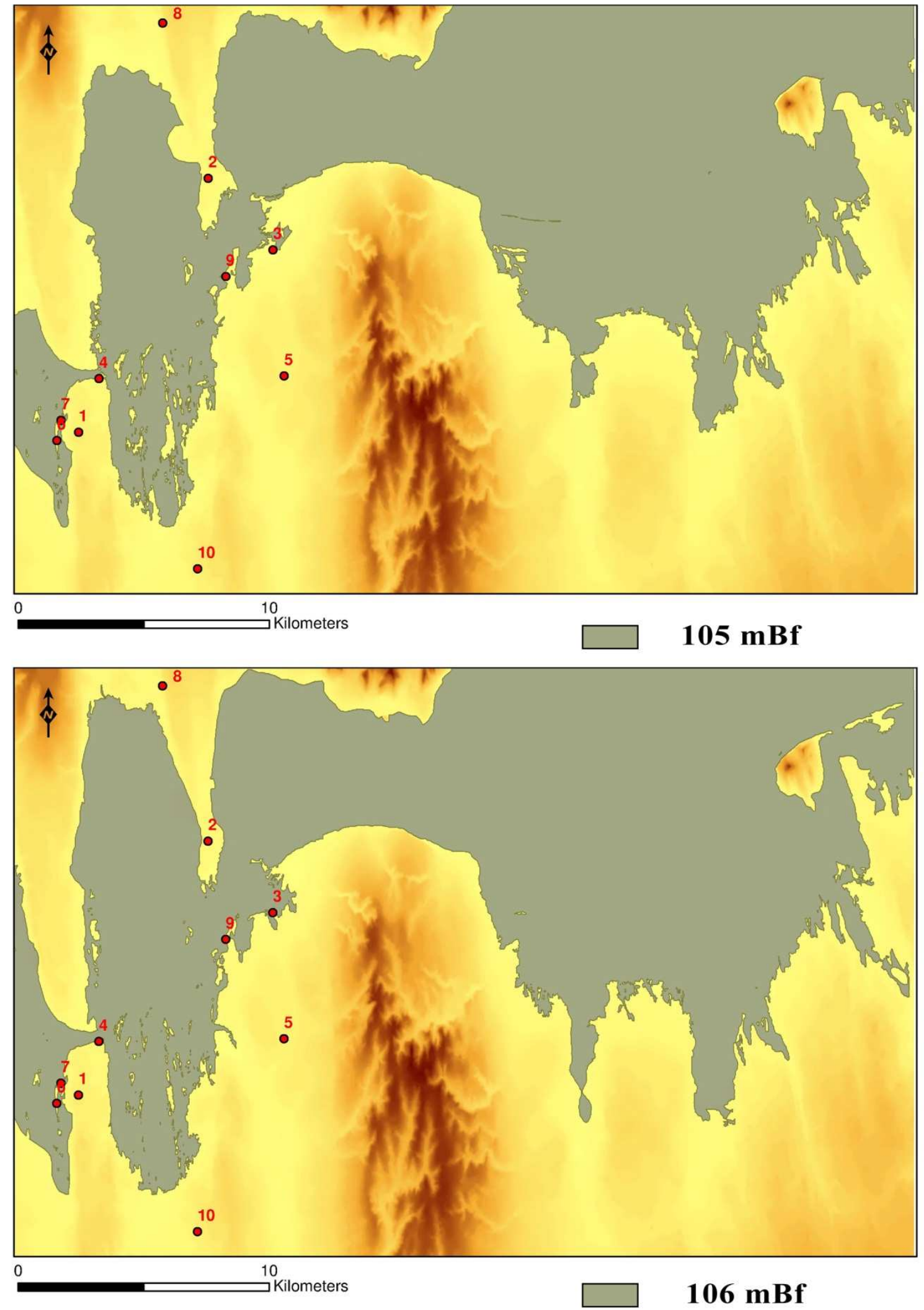

8.27.ábra. Több korszakú lelöhelyek: 1. Balatonmagyaród-Kányavár; Keszthely-Fenékpuszta; 3. Vörs-Battyáni-disznólegelö; 4. Balatonmagyaród-Hídvégpuszta; 5. Tikos-Homokgödrök; 6. Balatonmagyaród-Kányavári-sziget; 7. Balatonmagyaród-Szarkavári-sziget; 8. Keszthely-Gátidomb; 9. Vörs-Kerékerdő; 10. Szőkedencs-Cölömpös-árok 

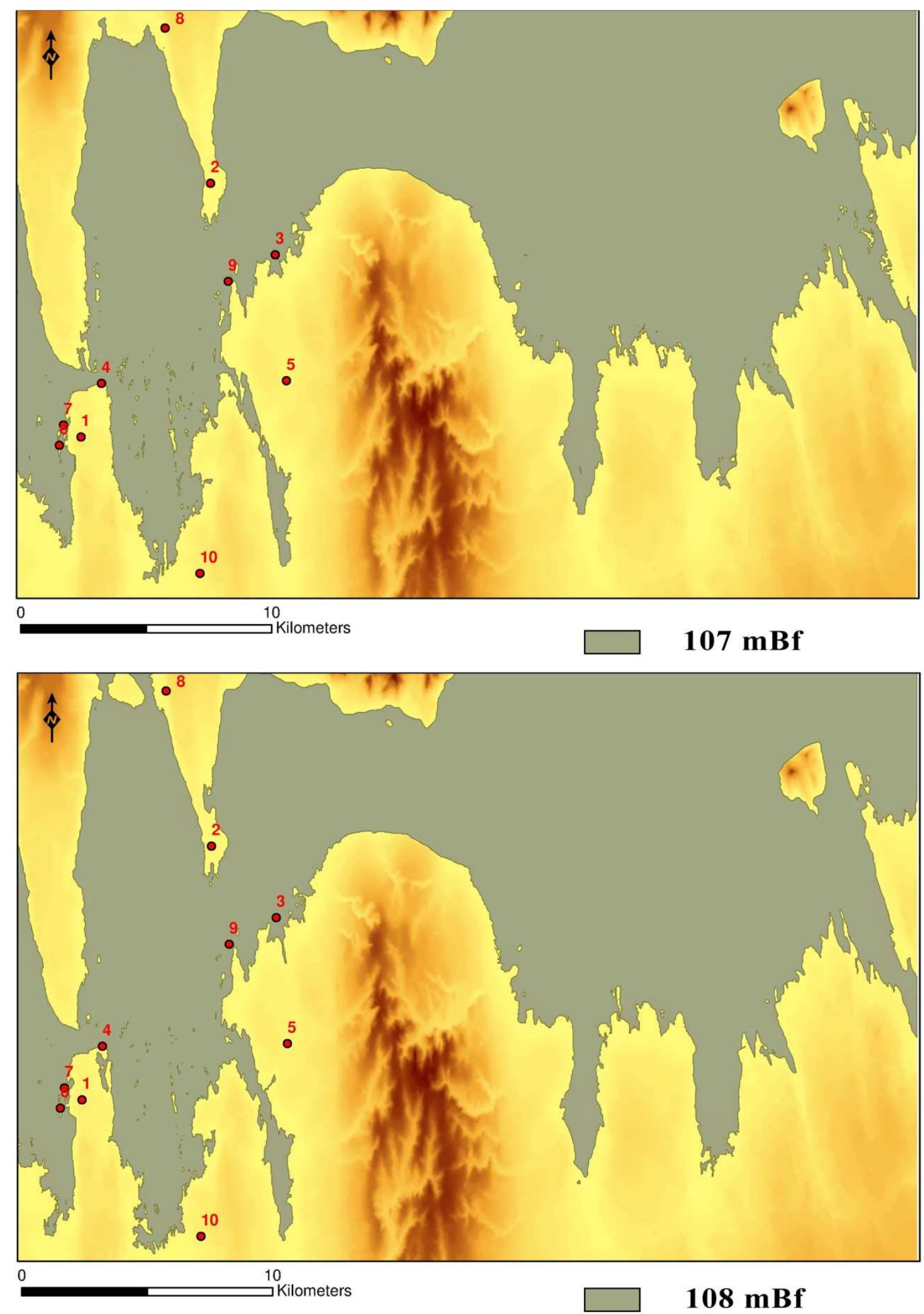

8.28.ábra. Több korszakú lelőhelyek: 1. Balatonmagyaród-Kányavár; Keszthely-Fenékpuszta; 3. Vörs-Battyáni-disznólegelö; 4. Balatonmagyaród-Hídvégpuszta; 5. Tikos-Homokgödrök; 6. Balatonmagyaród-Kányavári-sziget; 7. Balatonmagyaród-Szarkavári-sziget; 8. Keszthely-Gátidomb; 9. Vörs-Kerékerdő; 10. Szőkedencs-Cölömpös-árok 


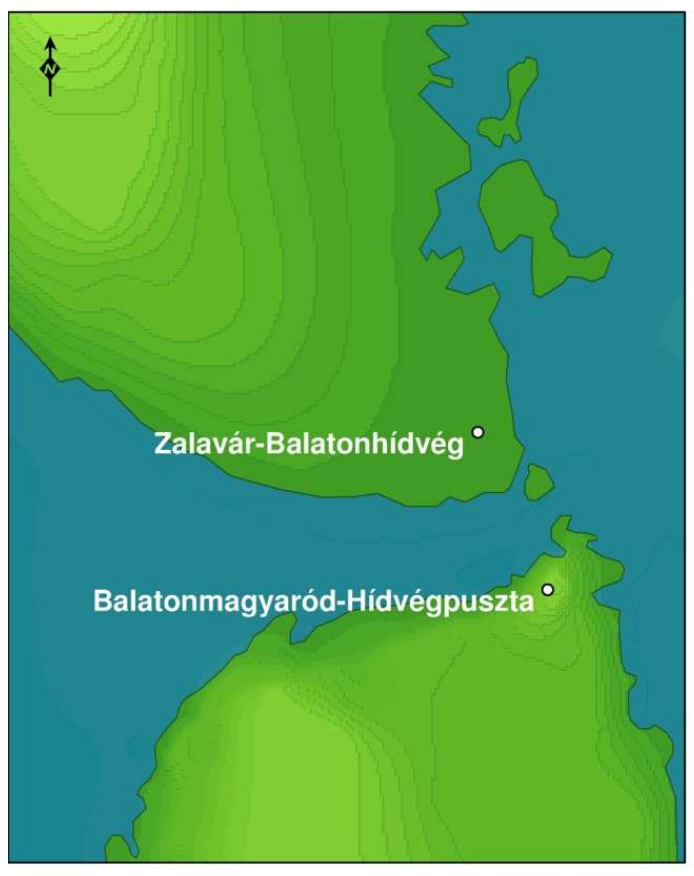

1.

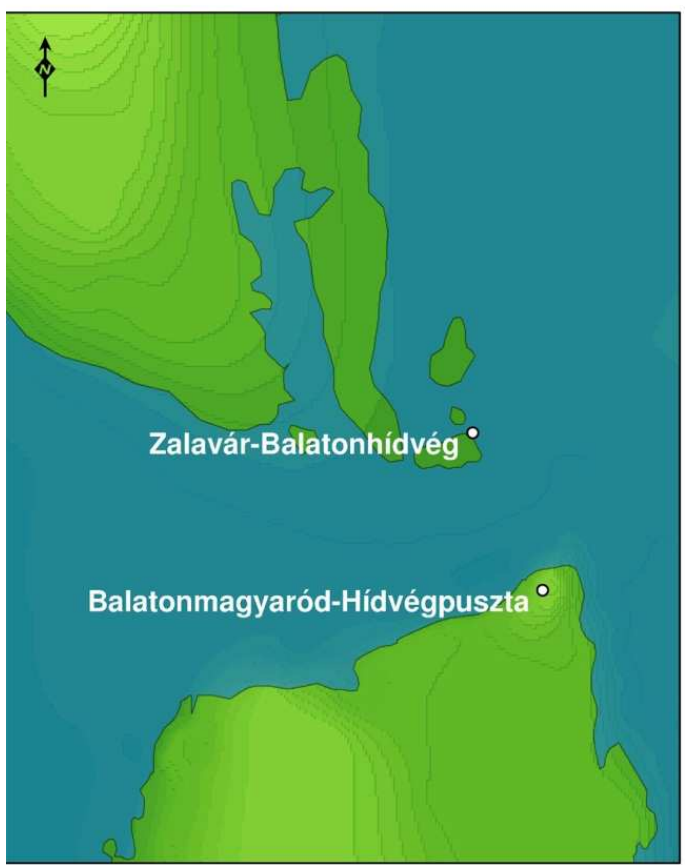

1 Kilometers

3.

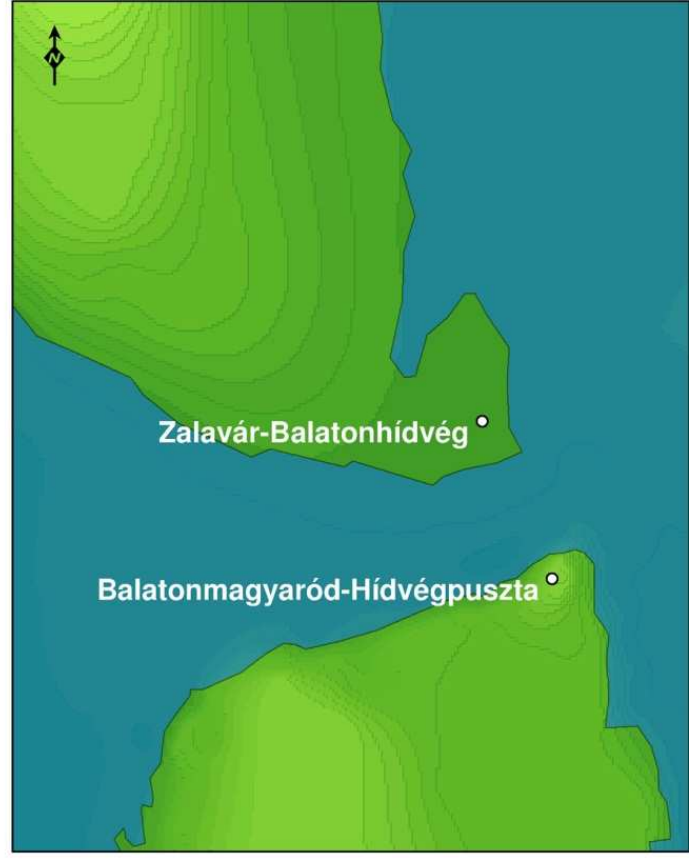

2.

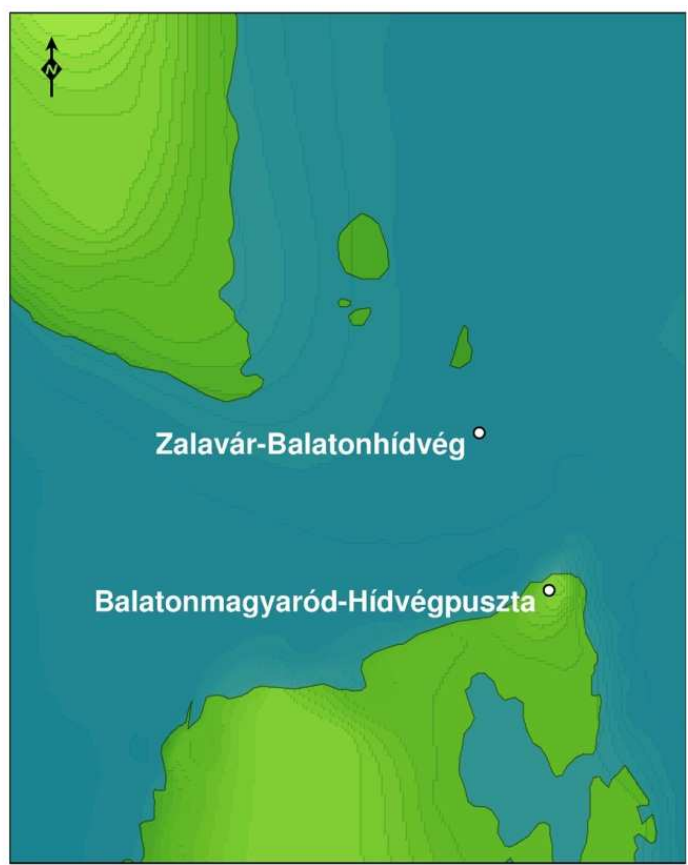

4.

8.29. ábra. Balatonmagyaród-Hídvégpuszta és Zamárdi-Balatonhídvég lelőhelyek eltérő geomorfológiai helyzete négy különböző vízállás esetén: 1. - 105 mBf; 2. - 106 mBf; 3. - 107 $m B f ; 4 .-108 m B f$ 


\section{9. Összefoglalás}

A Balaton vízállásában az utóbbi két évtizedben bekövetkezett szélsőséges értékek és az ezt befolyásoló folyamatok kapcsán egyre gyakrabban merül fel a tó folyamatos, és megfelelő szolgáltatásokat nyújtani tudó állapotfenntartásának kérdésköre.

A tó jelenlegi állapotának és folyamatos használhatóságának fenntartását napjainkra komoly törvényi szabályozás, vízgazdálkodási terv és intézkedési rendszer biztosítja. Ezek az intézkedéssorozatok egy olyan, mára már gyakorlatilag visszafordíthatatlan folyamatok által kialakított környezeti állapot egyensúlyának fenntartására és biztosítására, valamint szabályozott fejlesztésére irányulnak, amelyek az antropogén beavatkozásoknak köszönhetően jelentősen eltérnek a tó természetes állapotától.

Habár napjainkban a Balaton mérete, engedélyezett vízállásmaximuma, partvonala, a parti területek jellege jelentősen eltér az egykori, természetes állapotoktól a tó vízállását ma is ugyan azok - az elsődlegesen klimatikus tényezők határozzák meg, mint a beavatkozásokat megelőző évezredekben.

A változások mögött húzódó okok felderítése biztosíthatja, hogy megértsük a tó viselkedésmechanizmusát és a folyamatok várható jövőbeli eredményeit előre tudjuk jelezni. Ebből a megfontolásból kiindulva doktori disszertációm készítésekor azt a célt jelöltem meg, hogy környezetrégészeti eszközökkel az utóbbi évtized során felhalmozódott, elsősorban régészeti adatmennyiség alapján kiegészítsem és esetlegesen új keretek közé helyezzem azt a már nem előzmények nélküli kutatást, amely a tó és az emberek közötti viszonyt és elsősorban a tó vízállásában bekövetkezett változások valamint az egykori települések elhelyezkedése közötti összefüggést vizsgálta. A régészeti időszakok kronológiai rendszerének segítségével - a geológiai, hidrológiai és környezettörténeti adatokra támaszkodva - a geológiai léptéknél ugyanis kisebb időbeli felbontású tendenciákat tudunk meghatározni a tó vízállásában bekövetkezett változások között. A Balaton vízállás tendenciái és a települések geomorfológiai összefüggéseinek vizsgálatát a tó természetes állapota mellett tanulmányoztam. Ez a természetes állapot a késő római időszakban, a Balaton római kori lecsapolásával szűnt meg. Ennek az emberi beavatkozásnak 
eredményeként azonban nem csak a Balaton, hanem a teljes Délkelet-Dunántúl természetes hidrológiai rendszere megváltozott. Így ennek az összetett, a Balaton medencéjénél jóval nagyobb területeket érintő beavatkozásnak és hatásának vizsgálata és részletes kidolgozása már meghaladná a doktori disszertáció terjedelmi kereteit.

A Balaton történeti korú vízszintváltozásainak vizsgálata elsősorban földtani érdeklődésű kutatóktól indult ki. Ebben az időszakban a régészeti összefüggésekről, a tó közelében lévő régészeti lelőhelyek geomorfológiai helyzetéről és az egykori emberek életére gyakorolt hatásáról kevés szó esett, a kíváncsiságuk elsősorban a Balatonnak, mint természeti jelenségnek szólt. Később, az 1960-as évek végétől, két kutató, a régész Sági Károly (1919-1997) és a geodéta, geológus Bendefy László (1904-1977) munkássága alapozta meg a Balaton kapcsán azt a környezetrégészeti szemléletet, hogy a régészeti jelenségek vizsgálata és a régészeti időrend korrelációja a vízszintváltozás tendenciáival megbízható információkat nyújthat a vízállásváltozás jellegéről és mértékéről a térképi ábrázolások megjelenése előtti régészeti időszakokból.

Az 1960-1970-es évek régészeti összefüggésű balatoni vízállás kutatásai után az érdeklődés a téma iránt a kétezres évek első évtizedében, az M7 autópálya megelőző régészeti feltárásai kapcsán merült fel újra. Ez a folyamat nem zárult le, napjainkban is tartanak még olyan, az autópálya feltárásokhoz, vagy a Keszthely-Fenékpuszta és környékének késő antik-kora népvándorláskori történetéhez kapcsolódó kutatási programok, amelyeknek szerves részei a környezettörténeti, környezetrégészeti elemzések. Ezekben a kutatásokban jelentős szerepet vállalnak Dr. Sümegi Pál és a Szegedi Tudományegyetem Földtani és Őslénytani Tanszékének munkatársai.

A vizsgálat alá vont terület tulajdonságainak, valamint a Balaton geológiai történetének és általános jellemzőinek áttekintése után, a tó mindenkori vízállásának az emberi megtelepedésre gyakorolt hatását két, egymást kiegészítő módszerrel tanulmányoztam. Az M7 autópálya megelőző feltárásainak tapasztalatai alapján megállapítható volt, hogy a löszhátakon feltárt, különböző korszakú települések elhelyezkedésének szempontjából az egyik legfontosabb tényező a domboldalak vízállásfüggő talajvízviszonyainak alakulása. A tófelület növekedésével megemelkedik a talajvíztükör szintje a domboldalak lejtőén. 
Ennek következtében a települések a tó közeli domboldalakon mindig olyan övezetben helyezkedtek el, amelyet a tó rövid távú vízállás-ingadozása közvetlenül nem befolyásolt. A letelepülő emberek olyan területeket szálltak meg, amelyeken a tároló vermeiket, földbe mélyített házaikat, sírjaikat nem veszélyeztette a tó évszakos vízállás-ingadozása által befolyásolt talajvíztükörmozgás, ugyanakkor a település vízellátását biztosító kutakat, víznyerő helyeket nem kellett túl mélyre ásni a talajvízszint eléréséhez. Más szóval a települések a domboldalnak azt a részét foglalták el, ahol a talajvíztükör mélysége mind a két feltételnek egyszerre eleget tett.

Ebből az elvből kiindulva, a 2003-2004 során Fábián Szilvia által feltárt Balatonkeresztúr-Réti-dűlő lelőhely területéről rendelkezésemre álló talajmechanikai fúrások adatai alapján elkészítettem a Marcali-hát keleti lejtőjének egy szakaszán a rekonstruálható rétegtani és talajvízszint viszonyokat. A talajvízmodell eredményeit összehasonlítottam a lelőhelyen feltárt régészeti korszakok megtelepedési zónáival. Az eredmények alapján elmondható, hogy a vizsgált korszakok túlnyomó többségének megtelepedései előnyben részesítették a domblejtő azon szakaszát, ahol a talajvíz a felszín viszonylagos közelségében van. A modernkori vízállás adatok és a talajvíztükör változása között tapasztalható összefüggés alapján megállapíthattam, hogy az intenzíven lakott zónában egy közel egy méteres ingadozás esetén sem jelentős a talajvíz szintjének a változása, valamint a rendkívül alacsony vízállás esetén sem süllyed túl mélyre. Minthogy a domboldalnak ez a szakasza a tó természetes állapotában több esetben, hosszabb időszakokon keresztül is lakott volt, nagyvalószínűséggel kijelenthető, hogy néhány évszázados intervallumban a tó vízszintje az 1-2 méteres vízingadozást nem haladta meg, mert az már olyan mértékű változásokat okozott volna a talajvíztükör mélységében, ami alapvetően befolyásolta volna a települések létét. A késő rézkori időszak kagylóiból elvégzett stabilizotópos geokémiai vizsgálatok adatai alapján az is bizonyítható volt, hogy a kisebb amplitúdójú, esetlegesen régészetileg azonosítható kulturális változásokat is előidéző klímaesemények a tó vízállásában nagymértékű változást nem okoztak.

A 20. század elején megépített Nyugati-övcsatorna visszaduzzasztó hatásának eredményeként a rendelkezésemre álló talajmechanikai adatokból kiindulva, az általam elkészített talajvíz modell a Balaton mai vízállása és a talajvíztükör 
mélysége közötti összefüggések közvetlen megállapítására nem alkalmas. Ebből adódóan a talajvíztükör adott értékű mélységéből a Balaton vízállásának tengerszint feletti magasságára nem tudunk következtetni, csak a változások tendenciájára és mértékére.

A balatoni vízszintváltozás által előidézett talajvíztükör mozgás vizsgálatának kiegészítésre elkészítettem egy nagyobb terület statikus vízborítási modelljét négy különböző vízállási értékre. A modellbe integráltam a kiválasztott területnek a középső neolitikum időszakától, a kora római korig tartó időszak korszakokra bontott, regisztrált lelőhelyállományát. A különböző vízborítások kiterjedése és a lelőhelyek geomorfológiai elhelyezkedésének összefüggései alapján következtettem a nagyobb régészeti korszakokon belüli vízállásokra, valamint a korszakok település hálózata közötti különbségekből a korszakok közötti tendenciákra.

A középső neolitikumtól a kora császárkorig terjedő időszakon belül az ingadozás mértékére a legtöbb információt azok a több korszakú lelőhelyek hordoznak, amelyek a vízállás emelkedésével a Balaton partvonalának közvetlen közelébe kerülnek Ezekre a lelőhelyekre jellemző, hogy a vízállás emelkedésével a modellben alkalmazott vízállásértékek alapján a vízállásminimum értékéhez viszonyított két méteres vízemelkedés esetén a lelőhelyek emberi megtelepedésre alkalmatlanná válnak. Ennek a megállapításnak, valamint annak a ténynek az összekapcsolásából, hogy a több korszakú lelőhely megtelepedései lefedik a teljes vizsgált időintervallumot arra következtethetünk, hogy a régészeti korszakokban a Balaton hosszú távú vízállás ingadozása belül maradt ezen a megfigyelt két méteres intervallumon.

Az alapján, hogy a régészeti korszakokra valószínűsíthető 1-2 méteres, hosszú távú balatoni vízingadozást mind a két, egymást kiegészítő modell alátámasztotta, kijelenthető, hogy a korábbi feltételezések, amelyek teljes régészeti korszakokra magasabb, vagy alacsonyabb vízállási periódusokat valószínűsítettek nem minden tekintetben állják meg a helyüket. A vizsgálataim alapján tó természetes állapotában a holocén időszak nagy részében ezen az 1-2 méteres intervallumon belül kiegyensúlyozott hosszú távú vízjárást állapíthattam meg, amelyet időlegesen rövidebb lefutású extrémebb állapotok szakíthattak meg. A szélsőségesebb környezeti események után a tó vízjárása visszaállt a 
kiegyensúlyozott értékek közé. A meghatározott 1-2 méteres intervallum tengerszint feletti abszolút szélső értékeinek egyértelmű meghatározására egyik modell sem volt alkalmas. A kutatások során tapasztaltak alapján azonban ezt az intervallumot 105-107 mBf tengerszint feletti magasságban valószínúsítem.

A rövid lefutású, szélsőséges vízállásokat kiváltó környezeti eseményeknek és időszakoknak az időpontjára és mértékére csak olyan, az előbbiekben említett folyamatban lévő és a jövőben formálódó, több tudományág vizsgálati módszereit felhasználó és összefogó kutatási program keretében lehet választ adni. 


\section{Conclusion}

Due to the extreme values of the water level of Lake Balaton during the past two decades and in connection with the processes determining them, the issue of the changes of the level of the lake has frequently become a topic of debate. The investigation of the causes of water level changes may help us understand the behavioural mechanisms of the lake and we may be able to predict the outcome of future processes.

From this starting point, the aim of my dissertation was to examine the relationship between the changes of water level and the location of settlements based on archaeological data, using environmental archaeological methods. With the help of the chronological system of archaeological periods it is possible to determine the tendencies of the changes of the water level of the lake with a higher temporal resolution that those of geological scale. I studied the correlation between the tendencies of the water level of Lake Balaton and the geomorphology of the settlement at the natural state of the lake.

I examined the impact of the changes of the water level on human settlement through two, complementary methodologies. From the point of view of the location of the settlements of various periods excavated on the loess ridges one of the most important factors are the groundwater characteristics of the hill sides that depend on the water level of the lake.

Based on the results of the soil mechanics coring available from the site of Balatonkeresztúr-Réti-dűlő, I prepared a stratigraphic reconstruction and groundwater level reconstructions at two values. I compared the results of the groundwater model with the occupation zones of the various archaeological periods attested at the site.

I concluded that in the most densely occupied area even a $1 \mathrm{~m}$ fluctuation did not cause significant changes in the groundwater level, and it did not decrease considerably even at low lake levels. Since this stretch of the hillside was settled on multiple occasions for longer periods at a natural state of the lake, it is highly probable that the fluctuation of the water level of the lake did not exceed 1-2 m within a few hundred years interval. 
In order to complement the investigation of the movement of the watertable caused by the water level of Lake Balaton I prepared the static water coverage model of a larger area at four water level values.

Based on the correlation between the extent of the various water coverage models and the geomorphologic character of the sites I was able to calculate the water level during various archaeological periods and phases, and from the differences between the settlement networks of the various periods I could identify tendencies from one period to the other.

It is characteristic for the multi-component sites of the region that with the rise of the water level, based on the water level values used in the model, a $2 \mathrm{~m}$ rise compared to the water level minimum made the site unsuitable for human occupation. Based on this, the long-term fluctuation of the water level of Lake Balaton remained within this observed $2 \mathrm{~m}$ interval.

Since the 1-2 m long-term water level fluctuation of Lake Balaton was supported by both complementary models, it can be established that those previous hypotheses, that suggested higher or lower water levels for entire archaeological periods, cannot be upheld in all respects. According to my findings, in the natural state of the lake, a balanced long-term water level fluctuation within a 1-2 m interval could be established during most of the Holocene, which were interrupted by short-term, more extreme episodes. After these extreme environmental events the water level movement changed back to more balanced values. Neither model, however, was suitable to provide absolute above sea level values for the determined 1-2 $\mathrm{m}$ interval. Based on the research, however, this interval can be estimated to have been at 105-107 m above Baltic Sea level. 


\section{Köszönetnyilvánítás}

A dolgozat elkészítésében nyújtott segítségéért számos embernek tartozom köszönettel. Elsősorban témavezetőmnek, Dr. Bondár Máriának (MTA BTK RI), aki rengeteg szakmai és emberi segítséget nyújtott a munka során, valamint hogy hihetetlen türelemmel terelgetett a disszertáció befejezése felé. Továbbá meg kell köszönnöm belső konzulensemnek, Dr. Sümegi Pálnak (SZTE TTIK) a megbeszéléseket, amelyek során több esetben felhívta figyelmemet a részletekben rejlő megoldásokra, illetve a sok, lelkes bíztatásra, amellyel megerősítette bennem a kutatásaimban rejlő lehetőségeket.

Köszönettel tartozom a Régészeti Intézet vezetőségének az aktív támogatásért, hogy a doktori tanulmányok és a disszertáció készítése kapcsán a lehetőségekhez mért anyagi támogatás mellett a fő feladatomnak a dolgozat megírását tekintették az elmúlt időszakba, amihez nyugodt munkafeltételeket biztosítottak.

Köszönettel tartozom mindazoknak, akik a kutatások során felhasznált régészeti adatok feltárásában és publikálásában közreműködtek, a kis-balatoni rekonstrukciós program és az M7 autópálya megelőző feltárásának minden résztvevőjének és az erről készült publikációk készítőinek.

Külön köszönettel tartozom a balatonkeresztúri feltárás ásatásvezetőjének és a késő rézkori telepanyag feldolgozójának, Fábián Szilviának, akinek kutatási eredményei nagyban megalapozták a dolgozat kiindulópontjának számító Balatonkeresztúr-Réti-dűlő lelőhely kiemelkedő szerepét.

Köszönet a Mesterházy Gábornak a munka során felmerülő térinformatika problémák megoldásában nyújtott segítségéért.

Végezetül, de egyáltalán nem utolsó sorban hatalmas köszönettel tartozom családomnak, feleségemnek, Fábián Szilviának hogy a rengeteg szakmai segítség mellett szellemi és lelki támogatást nyújtott a dolgozat készítésének idején. Édesanyámnak, Serlegi Gittának, édesapámnak Dr. Serlegi Kálmánnak, valamint anyósomnak, Kovács Tündének, hogy nyugodt hátteret biztosítottak a munka elvégzéséhez. És persze kisfiamnak, Bálintnak, amiért végtelen türelemmel viselte a sok szomorú és kiábrándító „most nem tudok, drágám!” választ, az „apa! játszol velem?" kérdésre. 


\section{Irodalomjegyzék}

Bándi 1967

Bánffy 2008

Bánffy et al. 1996

Bánffy - Sümegi 2012

Barna et al 2009

Bendefy 1968

Bendefy - V. Nagy 1969

Bendefy 1970
Bándi G.: Adatok a mészbetétes edények népe északdunántúli csoportjának történetéhez. Janus Pannonius Múzeum Évkönyve 1967, 9-43.

Bánffy E.: The boundary in western Transdanubia: variations of migration and adaptation. In: Living Well Together? Settlement and Materiality in the Neolithic of South-East and Central Europe. Ed: Bailey, D.W. Whittle, A. - Hofmann, D. Oxford 2008, 151 - 463.

Bánffy E. - Bondár M. - M. Virág Zs: A kultúra hajnala. In: Évezredek üzenete a láp világából. Régészeti kutatások a Kis-Balaton területén 1979-1992. Ed: Költő L. - Vándor L. Kaposvár-Zalaegerszeg, Zala Megyei Múzeumok Igazgatósága 1996, 15-31.

Bánffy E. - Sümegi P.: The early neolithic agroecological barrier in the Carpathian Basin: a zone for interaction In: Archaeological, Cultural and Linguistic Heritage: Festschrift for Erzsébet Jerem in Honour of her 70th Birthday. Ed: Anreiter, P. - Bánffy E. Bartosiewicz L. - Meid, W. - Metzner-Nebelsick, C. Budapest: 2012. 57-69.

Barna G. - Demény A. - Serlegi G. - Fábián Sz. - Sümegi $P$ - Fórizs I. - Cserny T.: Seasonal fluctuations in the Copper Age: stable isotope record of molluscan shells (Balaton region, Hungary) In: Bivalves Biomineralisation Archival Potential and Proxy Incorporation. Ed: André, L. - Dehairs, F - Mas, R. Planchon, F. - Versteegh E (szerk.) Brussels 2009, 5963.

Bendefy L.: A Balaton vízszintjének változásai a neolitikumtól napjainkig. Hidrológiai Közlöny 6 (1968) 257-263.

Bendefy L. - V. Nagy I.: A Balaton évszázados partvonalváltozásai. Budapest, 1969.

Bendefy L.: Egy terészettudományi vonatkozású vita margójára. Földrajzi Értesítő 19/3 (1970) 365-368. 
Bendefy 1972

Bóna 1964

Bondár 1985

Bondár 1991

Bondár et al. 1996

Bondár et al. 2001

Branch et al. 2005

Butzer 1982

Cholnoky 1918

Demény et al. 2010
Bendefy L.: Természeti és antropogén tényezők hatása a Balaton vízállására. Földrajzi Értesítő 21/2-3 (1972) 335-358.

Bóna I.: The Peoples of Southern Origin of Early Bronze Age in Hungary. II. The Somogyvár Group. Alba Régia 4-5 (196-1964), 17-63.

Bondár M.: Balatonmagyaród-Kiskányavár. Archaeológiai Értesítő 112 (1985), 268.

Bondár M.: A badeni kultúra telepe Balatonmagyaródon. Zalai Múzeum 3 (1991), 137154.

Bondár M. - Honti Sz. - Horváth L.: Hellsz északi szomszédai. In: Évezredek üzenete a láp világából. Régészeti kutatások a Kis-Balaton területén 19791992. Ed: Költő L. - Vándor L. Kaposvár-Zalaegerszeg, Zala Megyei Múzeumok Igazgatósága 1996, 43-75.

Bondár M. - Honti Sz. - Kiss V.: A tervezett M7 autópálya Somogy megyei szakaszának megelőző régészeti feltárása (1992-1999). Előzetes jelentés I. Somogy Megyei Múzeumok Közleményei 14 (2000) 91-114.

Branch, N. - Canti, M. - Clark, P. - Turney, Ch.: Environmental Archaeology - Theoretical and practical approaches. London, 2005.

Butzer, K.W.: Archaeology as human ecology: Method and theory for contextual approach. Cambridge University Press 1982.

Cholnoky J.: A Balaton hidrográfiája. A Balaton Tudományos Tanulmányozásának Eredményei I/2. Budapest, 1918.

Demény A. - Schöll-Barna G. - Siklósy Z. - Bodnár M. Sümegi P. - Serlegi G. - Fábián Sz. - Fórizs I.:

$\mathrm{Az}$ elmúlt ötezer év éghajlat-változási eseményei a Kárpát-medencében és társadalmi hatásaik.

Klíma 21 füzetek 59 (2010), 82-94. 
Dincauze 2000

Dövényi 2010

EnvArch 2005

EnvArch 2007

Evans 2003

Évezredek 1996

Fábián 2004a

Fábián 2004b

Fábián 2005
Dincauze, D.F.: Environmental Archaeology: Principles and Practice. Cambridge University Press, 2000.

Dövényi Z.: Magyarország kistájainak katasztere Ed: Dövényi, Z. Budapest 2010.

Environmental Archaeology of North-Eastern Hungary. Ed: Gál E. - Juhász I. - Sümegi P. Varia Archaeologica Hungarica XIX. Budapest, 2005.

Environmental Archaeology in Transdanubia. Ed: Zatykó Cs. - Juhász I. - Sümegi P. Varia Archaeologica Hungarica XX. Budapest, 2007.

Evans J.G.: Environmental Archaeology and the Social Order. London, 2003.

Évezredek üzenete a láp világából. Régészeti kutatások a Kis-Balaton területén 1979-1992. Ed: Költő L. - Vándor L. Kaposvár-Zalaegerszeg, Zala Megyei Múzeumok Igazgatósága, 1996.

Fábián Sz: Balatonkeresztúr-Réti-dűlő (M7/S-35 lelőhely). In: Honti et al.: A tervezett M7-es autópálya Somogy megyei szakaszának megelőző régészeti feltárása (2002-2003). Előzetes jelentés III. [Preliminary Report III. The Preceding Archaeological Excavations (2002-2003) on the M7 Highway in Somogy County.] Somogyi Múzeumok Közleményei 16 (2004) 10-15.

Fábián Sz.: Balatonkeresztúr-Réti dűlő. Régészeti kutatások Magyarországon 2003 (2004) 157-158.

Fábián Sz.: Balatonkeresztúr, Réti-dűlő. Régészeti Kutatások Magyarországon 2004. (2005) 172-173. 
Fábián 2007

Fábián et al. 2007

Fábián-Serlegi 2007

Fábián-Serlegi 2009

Freeden-Vida 2007
Fábián Sz:: Balatonkeresztúr-Réti-dűlő (M7/S-35 lelőhely). In: Honti et al. Régészeti Kutatások az M7-es autópálya Somogy megyei szakaszán és a 67-es úton (2004-2005). Előzetes jelentés IV. [Archaeological Research on the Somogy County Section of the M7 Higway and on Route No. 67. (2004-2005). Preliminary Report IV.] Somogyi Múzeumok Közleményei 17 (2006) [2007] 26-29.

Fábián Sz. - Koós I. - Hajdú Á.: Balatonkeresztúr-Rétidűlő 2-3-4. In: Honti et al. Régészeti kutatások az M7es autópálya Somogy megyei szakaszán és a 67-es úton (2004-2005) Előzetes jelentés IV. (Archaeological research on the Somogy county of the M7 highway and Route No. 67. (2004-2005) Preliminary report IV. Somogyi Múzeumok Közleményei 17 (2006) [2007] 42-44.

Fábián Sz. - Serlegi G.: Egy telep hét élete: Ember és táj kapcsolata Balatonkeresztúr-Réti-dűlő lelőhelyen. [Seven Lives of a Settlement: The People and Their Environment at the Balatonkeresztúr-Réti-dűlő Archaeological Site.] In: Diszciplínák határain innen és túl. Fiatal Kutatók Fóruma 2. - 2006. Ed. M. Balogh. Budapest 2007, 273-284.

Fábián Sz. - Serlegi G.: Settlement and environment in the Late Copper Age along the southern shore of Lake Balaton in Hungary. Regional Analyses of Spatial and Social Dynamics (eds: Tina Thurston - Roderick B. Salisbury). Cambridge Scholars Publishing 2009, 199231.

von Freeden, U. - Vida T.: Ausgrabungen des langobardenzeitlichen Gräberfeldes von Szólád, Komitat Somogy, Ungarn. Vorbericht und Überblick über langobardenzeitliche Besiedlung am Plattensee. (mit einem Exkurs von Péter Skriba) Germania 85/2 (2007), 359-384. 
Füzes-Horváth 1971

Gabler 1982

Hawkes 1954

Heinrich-Tamáska 2014 Heinrich-Tamáska O.: Research perspectives on landscape archaeology at the western end of Lake Balaton int he first millenium AD. In. Mensh, Siedlung und Landschaft im Wechsel der Jahrtausende am Balaton - People, Settlement and Landscape On the Lake Balaton over the Millennia. Ed: HeinrichTamáska O. - Straub P. Castellum Pannonicum Pelsonense Vol. 4. Budapest - Leipzig - Keszthely Rahden 2014, 403-428.

Higgs 1975

Honti 1986a

Honti 1986b

Honti 1994
Higgs, E.: Site catchment analysis: a concise guide tofield methods. In: Palaeoeconomy. Ed: Higgs, E.S. Cambridge 1975, 223-224.

Honti Sz: Főnyed-Feketesziget. Archaeológiai Értesítő 113 (1986), 265.

Honti Sz.: Vörs-Battyán, Schweineweide. Archaeológiai Értesítő 113 (1986), 271.

Honti Sz: Angaben zur Geschichte der Urnenfeldkultur in Südwest-Transdanubien. Actes du XII Congres International des Sciences Préhistoriques. Bratislava 1991 (1994), 147-155. 
Honti et al. 2002

Honti et al. 2004

Honti et al. 2007

Horváth 1984

Horváth 1986

Horváth 1987

Horváth 1994
Honti, Sz. - Belényesy, K. - Gallina, Zs. - Kiss, V. Kulcsár, G. - Marton, T. - Nagy, Á. - Németh, P. G. Oross, K. - Sebők, K. - Somogyi, K.: A tervezett M7-es autópálya Somogy megyei szakaszán 2000-2001-ben végzett megelőző régészeti feltárások. Előzetes jelentés II. Somogy Megyei Múzeumok Közleményei 15 (2002) 3-36.

Honti, Sz. - Belényesy, K. - Fábián, Sz. - Gallina, Zs.Hajdú, Á. D. - Hansel, B.- Horváth, T. - Kiss, V. - Koós, I. - Marton, T. - Németh, P. G. - Oross, K. - Osztás, A. Polgár, P. - P-Szeőke, J. - Serlegi, G. - Siklósi, Zs. Sófalvi, A. - Virágos,G., A tervezett M7-es autópálya Somogy megyei szakaszánakmegelőző régészeti feltárása (2002-2003). Előzetes jelentés III. (Preliminry Report III. The preceding archaeological excavations (2002-2003) on the M7 highway in Somogy county. Somogy Megyei Múzeumok Közleményei 16 (2004) 3-70.

Honti, Sz. - Fábián, Sz. - Gallina, Zs. - Hajdú, Á. D. Hornok, P. - Koós, I. - Mersdorf, Zs. - Molnár, I. Németh, P. G. - Polgár, P. - P. Szeőke, J. - Serlegi, G.Siklósi, Zs. - Sipos, C. - Somogyi, K.: Régészeti Kutatások az M7-es autópálya Somogy megyei szakaszán és a 67-es úton (2004-2005). Előzetes jelentés IV. (Archaeological research on the Somogy county section of the M7 higway and on Route No. 67.(2004-2005). Preliminary report IV) Somogy Megyei Múzeumok Közleményei 17 (2006) [2007] 770 .

Horváth L.: Balatonmagyaród-Kiskányavár. Archaeológiai Értesítő 111 (1984), 257.

Horváth L.: Balatonmagyaród-Kiskányavár. Archaeológiai Értesítő 113 (1986), 264.

Horváth L.: Késő vaskori ház és településtípusok DélZalában. Zalai Múzeum 1 (1987), 59-80.

Horváth L.: Adatok Délnyugat-Dunántúl késő bronzkorának történetéhez. Zalai Múzeum 5 (1994). 218-235. 
Horváth et al. 1996

Ickerodt 2006

Juhász 2007

Jakab et al 2005

Jerem 2003

Kalicz-Schreiber 1991

Kiss 2006

Kiss 2012

Kulcsár 2009
Horváth L. - Müller R. - Németh P.G.: A római imperium határvidékén. In: Évezredek üzenete a láp világából. Régészeti kutatások a Kis-Balaton területén 1979-1992. Ed: Költő L. - Vándor L. KaposvárZalaegerszeg, Zala Megyei Múzeumok Igazgatósága 1996, 77-83.

Ickerodt, U.: The Term: „Cultural Landscape”. In: Landscape Ideologies. Ed: Meier, T. Archaeolingua, Series Minor 22, Budapest 2006, 53-79.

Juhász I.: Comparison and correlation of four pollen sequences from the Little Balaton region (Alsópáhok, Főnyed, Keszthely and Zalavár). In: Environmental Archaeology in Transdanubia. Ed: Zatykó Cs. - Juhász I. - Sümegi P. Varia Archaeologica Hungarica XX. Budapest, 2007, 36-51.

Jakab G. - Sümegi P. - Szántó Zs.: Késő-glaciális és holocén vízszintingadozások a Szigligeti-öbölben (Balaton) makrofosszília vizsgálatok eredményei alapján. Földtani Közlöny 135/3 (2005), 405-429.

Jerem E.: Környezetrégészet - egy új tudományág születése. In: Magyar régészet az ezredfordulón. Ed: Visy Zs.-Nagy M. Budapest, 2003.

Kalicz-Schreiber R.: A Somogyvár-Vinkovci kultúra dél-északi irányú közvetítő szerepe a kora bronzkorban. Budapest Régiségei 27 (1991), 9-43.

Kiss Cs.: Középkori település Balatonkeresztúr határában. Szakdolgozat. SZTE BTK, Régészeti Tanszék 2006.

Kiss V.: Middle Bronze Age Encrusted Pottery. Varia Archaeologica Hungarica XXVII. Budapest, 2012.

Kulcsár G.: The beginnings of the Bronze Age int he Carpathian Basi. The Makó-Kosihy-Čaka and teh Somogyvár-Vinkovci Cultures in Hungary. Varia Archaeologica Hungarika XXIII. Budapest, 2009. 
László 1913

Leeuw 2001

Leusen et al. 2009

Lóczy 1913

M. Virág 1986a

M. Virág 1986b

M. Virág 1990

M. Virág 1999

Marosi-Szilárd 1981

Marosi-Somogyi 1990

McGlade 1995
László G.: A balatonmelléki tőzeglápok és berkek. A Balaton Tudományos Tanulmányozásának Eredményei I/1. Budapest, 1913.

van der Leeuw, S.E.: Environmental Archaeology. In: International Encyclopedia of the Social and Behavioural Sciences. Oxford 2001, 4585-4589.

van Leusen, M. - Millard, A.R. - Ducke, B.: Dealing with uncertainty in archaeological prediction. In :

Archaeological Prediction and Risk Management. Alternatives to Current Practice. Ed: Kamermans, H. van Leusen, M. - Verhagen, P. Archaeological Studies Leiden University 17 (2009), 123-160.

Lóczy L.: A Balaton tó tudományos vizsgálatának eredményei. Magyar Földrajzi Társaság Balaton Bizottságának kiadványa. Budapest, 1913.

M. Virág Zs.: Zalavár-Balatonhídvég. Archaeológiai Értesítő 113 (1986), 271.

M. Virág Zs.: Sármellék-Égenföld. Archaeológiai Értesítő 113 (1986), 269.

M. Virág Zs.: Vorbericht über die Ergebnisse der Freilegung der kupferzeitlichen Siedlung von ZalavárBasasziget. Zalai Múzeum 2 (1990), 71-81.

M. Virág Zs.: A badeni kultúra rézleletei SármellékÉgenföldről. Zalai Múzeum 9 (1999), 33-54.

Marosi S. - Szilárd J.: A Balaton kialakulása. Földrajzi Közlemények 29 (1981), 1-30.

Marosi S.- Somogyi S: Magyarország kistájainak katasztere II. Ed: Marosi S - Somogyi S. Budapest, 1990.

McGlade, J.: Archaeology and the ecodynamics of human-modified landscapes. Antiquity 62 (1995) 113-132. 
Medzihradszky 2005 Medzihradszly Zs.: Holocene Vegetation History an Human Activity in the Kis-Balaton Area, Western Hungary. Studia Botanica Hungarica 36 (2005) 77100.

MÉK 1972

Magyar Értelmező Kéziszótár. Ed: Juhász J.-Szőke I.-O Nagy G.-Kovalovszky M.) Budapest, 1972.

Mesterházy - Stibrányi 2011

Prediktív régészeti modellek és a magyar örökségvédelem. Topográfiai Tanulmányok 12011 , 127. (http://www.mnm-nok.gov.hu/wpcontent/uploads/2013/01/mesterhazystibranyi prediktiv modellezes.pdf)

Mészáros-Serlegi 2011 Mészáros 0. - Serlegi G.: The impact of environmental change on Medieval settlement structure in Transdanubia. Acta Archaeoligica Academiae Scientiarium Hungaricae 62 (2011), 199-219.

Moran 2010

Moran, E.F.: Environmental Social Sience - HumanEnvironment Interaction and Sustainability. WileyBlackwell, 2010.

MRT1 1966

Magyarország Régészeti Topográfiája 1. kötet. Veszprém megye régészeti topográfiája. A keszthelyi és tapolcai járás. Ed: Bakay K. - Kalicz N. - Sági K. Budapest, 1966.

Müller 1996

Müller R.: Római kor. In: Évezredek üzenete a láp világából. Régészeti kutatások a Kis-Balaton területén 1979-1992. Ed: Költő L. - Vándor L. KaposvárZalaegerszeg, Zala Megyei Múzeumok Igazgatósága 1996, 85-88.

Nagy-Bodor-Cserny 1998

Nagy-Bodor E.-Cserny T.: A balatoni öblök vízborítottságának összehasonlító fejlődéstörténete a palinológiai vizsgálatok eredményei alapján. Hidrológiai Közlöny 78 (1998) 360-361. 
Németh 2007

Németh P.G.: A Balaton déli partvidéke és a DélDunántúl a római korban (Kr. u. 1-5. század). In: Gördülő idő. Régészeti feltárások az M7-es autópálya Somogy megyei szakaszán Zamárdi és Ordacsehi között. [Rolling Time. Excavations on the M7 Motorway in County Somogy between Zamárdi and Ordacsehi.] Ed. Belényesy K., Honti Sz., Kiss V. Kaposvár-Budapest 2007, 41-45.

Pásztókai-Szeőke-Serlegi 2013

Pásztókai-Szeőke J., Serlegi G.: „De mit tettek értünk a rómaiak?" In: Ókor 2013/3, 68-79.

Pauknerova et al. 2013 Pauknerova, K.-Salisbury, R.B.-Baumanova, M.: Human-Landscape Interaction in Prehistoric Central Europe: Analysis of Natural and Built Environments. Anthropologie LI/2, 2013, 131-142.

Pécsi 1981

Pécsi M.: A Dunántúli-dombság. In: Magyarország tájföldrajza, 4. Ed: Pécsi M. Budapest, 1981.

Rapp-Hill 2006

Rapp, G.R.-Hill, Ch.H.: Geoarchaeology: The Earthscience Approach to Archaeological Interpretation. Yale University Press, 2006.

Renfrew-Bahn 1999 Renfrew, C.-Bahn, P.: Régészet - elmélet, módszer, gyakorlat. Budapest, 1999.

Rosignol 1992

Rosignol, J.: Concepts, Methods and Theory building: A landscape approach in: Space, Time and Archaeological Landscape. Ed: Rosignol, J.Wandsnider, L. Interdisciplinari Contributions to Archaeology XVI. New York-London 1992, 3-16.

Sági 1968a

Sági K.: A Balaton szerepe Fenékpuszta, Keszthely és Zalavár IV-IX. századi történetének alakulásában. Antik Tanulmányok 15 (1968), 15-46. 
Sági 1968b

Sági 1970

Sági 1971

Sági-Füzes 1973

Schöll-Barna et al. 2012

Schwabedissen 1958

Serlegi 2007

Serlegi 2009
Sági K.: A Balaton vízállástendenciái 1863-ig a történeti és kartográfiai adatok tükrében. A Veszprém Megyei Múzeumok Közleményei 7 (1968), 441-462.

Sági K.: Egy Történeti vita természettudományi kapcsolatai. Földrajzi Értesítő 19/2 (1970), 200-207.

Sági K.: Újabb balatoni vita. Földrajzi Értesítő 20/4 (1971), 485-490.

Sági K. - Füzes M.: Újabb adatok a Balaton 1863 előtti vízállás tendenciáinak kérdéséhez. Somogyi Múzeumok Közleményei 1 (1973), 247-260.

Schöll-Barna G. - Demény A. - Serlegi G. - Fábián Sz. Sümegi P. - Fórizs I. - Bajnóczi B.: Climatic variability in the Late Copper Age: Stable isotope fluctuation of prehistoric Unio pictorum (Unionidae) shells from Lake Balaton (Hungary) Journal of Paleolimnology 47/1 (2012), 87-100.

Schwabedissen, H.: Untersuchung mesolitischneolitischer Moorsiedlungen in Schleswig-Holstein. Neue Ausgrabungen in Deutschland. Berlin, 1958. 2642.

Serlegi G.: A balatonkeresztúri „vízmérce." Környezetrégészeti információk a Balaton déli partjának római kori történetéhez. [The „water gauge" of Balatonkeresztúr. Environmental Archaeological Data on the Roman Period History of the Southern Shore of Lake Balaton.] FiRKáK I. Fiatal Római Koros Kutatók I. Konferenciakötete. Ed. Bíró Sz. Győr 2007, 297-317.

Serlegi G.: The Waterlogged Century. In: Ex Officina... Studia in honorem Dénes Gábler. Emlékkönyv Gábler Dénes 70. születésnapjára. Ed: Bíró Sz. Győr 2009, 501-514. 
Serlegi et al. 2012

Simonyi 1969

Skriba 2006

Smyntyna 2006

Stibrányi et al. 2012

Sümegi 2003

Sümegi 2013
Serlegi G. - Fábián Sz. - Daróczi-Szabó M. - Shöll-Barna G. - Demény A.: Éghajlati és környezeti változások a késő rézkor folyamán a Dunántúlon. In: Környezet ember - kultúra. Az alkalmazott természettudományok és a régészet párbeszéde. Ed: Kreiter A. - Pető Á. - Tugya B. Budapest 2012, 139150.

Simonyi D.: Megjegyzések Sági Károly balatoni „földrajzi kép”-éhez. Földrajzi Értesítő 18/2 (1969) 260-262.

Skriba P.: Langobard települések a Balaton partján (Az M7-es autópálya megelőző régészeti feltárásai 2002-2004-ben: Balatonlelle és Balatonkeresztúr). In: „Hadak útján...” XV. A népvándorlás kor fiatal kutatói 15. konferenciájának előadásai. Ed: László J. Schmidtmayer R. Tatabányai Múzeum Tudományos Füzetek 8. Tatabánya 2004, 55-93.

Smyntyna, O.V.: Landscape in prehistoric archaeology: Compering Western and Eastern Paradigms. In: Landscape Ideologies. Ed: Meier, T. Archaeolingua, Series Minor 22, Budapest 2006, 8196.

Stibrányi M. - Mesterházy G. - Padányi-Gulyás G.: Régészeti feltárás előtt - vagy helyett. Régészeti lelőhely-azonosítás, térinformatika, prediktív modellezés. MNM NÖK Tudományos-népszerüsítő füzetei 5 (2012).

Sümegi P.: A régészeti geológia és a történeti ökológia alapjai. Szeged, 2003.

Sümegi P. :Pre-Neolithization: Reconstructing The Environmental Background to Life Way Changes in the Late Mesolithic of the Carpathian Basin

In: Comparative Archaeology and Paleoclimatology. Socio-cultural responses to a changing world. BAR International Series; 2456. Oxford 2013,109-117. 
Sümegi et al. 2004

Sümegi et al. 2007

Sümegi et al. 2009

Sümegi et al. 2011
Sümegi P. - Bodor E. - Juhász I. - Hunyadfalvi Z. Herbrich K. - Molnár G. - Szegvári S. - Imre M. - Tímár G.: A balatoni déli autópálya régészeti lelőhelyeinek környezettörténeti feldolgozása. [Environmental History Investigation on the Archaeological Sites of the South Motorway at Balaton.] In: $\mathrm{M} \Omega \mathrm{M} \Omega \Sigma$ III. Őskoros Kutatók III. Összejövetele. Ed. Ilon G. Szombathely 2004, 399-420.

Sümegi P. - Bodor E. - Juhász I. - Hunyadfalvi Z. Herbrich K. - Molnár G. - Tímár G.: A Balaton déli partján feltárt régészeti lelőhelyek környezettörténeti feldolgozása. In: Gördülő idő. Régészeti feltárások az M7-es autópálya Somogy megyei szakaszán Zamárdi és Ordacsehi között. [Rolling Time. Excavations on the M7 Motorway in County Somogy between Zamárdi and Ordacsehi.] Ed. Belényesy K. - Honti Sz. - Kiss V. Kaposvár-Budapest 2007, 241-253.

Sümegi P. - Töröcsik T. - Jakab G. - Gulyás S. - Pomázi P. - Majkut P. - Páll G.D. - Persaits G. - Bodor E.: The environmental history of Fenékpuszta with a special attentionto the climate and recipitation of the last 2000 years. In: Journal of Environmental Geography Vol. II. No. 3-4, 5-14.

Sümegi P. - Heinrich-Tamáska O. - Törőcsik T. - Jakab G. - Pomázi P. - Majkut P. - Páll D. G. - Persaits G. Bodor E: Reconstruction of the environmental history of Keszthely-Fenékpuszta. In: Keszthely-Fenékpuszta im Kontext spatantiker Kontinuitatforschung zwischen Noricum und Moesia. Ed: Heinrich-Tamáska O. Castellum Pannonicum Pelsonense; 2. BudapestLeipzig 2011, 541-572. 
Sümegi et al. 2012a

Sümegi et al 2013a

Sümegi et al 2013b

Sümegi et al. 2014

Szabó 1963
Sümegi P. - Gulyás S. - Persaits G.: Magyarország környezettörténete: ember és környezet hosszú távú kapcsolata a Kárpát-medencében: Példa az alluviális löszös szigetek kora neolit hasznosítására (NagykörüTSz Gyümölcsös).

In: Környezet - ember - kultúra: Az alkalmazott természettudományok és a régészet párbeszéde Environment - human - culture: Dialogue between applied sciences and archaeology. Ed: Kreiter A. - Pető Á. - Tugya B. Magyar Nemzeti Múzeum Nemzeti Örökségvédelmi Központ 2010. október 6 - 8-án megrendezett konferenciájának tanulmánykötete. Konferencia helye, ideje: Budapest, Magyarország, 2010.10.06-2010.10.08. Budapest: Magyar Nemzeti Múzeum Nemzeti Örökségvédelmi Központ, 2012, 115-124.

Sümegi P. - Gulyás S.: - Persaits G.: The Geoarcheological Evolution of the Loess-Covered Alluvial lgár and Its Role in Shaping Human Settlement Strategies. In: Moments in Time: Papers Presented to Pál Raczky on His 60th Birthday. Ed: Anders Alexandra, Kulcsár G, Kalla G, Kiss V, V Szabó G. Ősrégészeti Tanulmányok - Prehistoric Studies;1.Budapest 2013, 901-912.

Sümegi P. - Gulyás S. - Kertész R. - Tímár G.: Mesolithic-Neolithic Transition in the Carpathian Basin: was there an Ecological Trap during the Neolithic?

In: Comparative Archaeology and Paleoclimatology. Socio-cultural responses to a changing world. BAR International Series; 2456. Oxford 2013,119-126.

Sümegi P. - Schöll-Barna G. - Demény A.: A Balaton vízszintváltozásainak 20 ezer éve. Természet Világa 2014 február, 74-78.

Szabó M.: A badacsonylábdi kettősfej kérdéséhez. Archaeológiai Értesítő 90 (1963), 69-74.

Szántó-Medzihradszky 2004

Szántó Zs. - Medzihradszky Zs.: Holocene Environmental Changes in Western Hungary. Radiocarbon 46/2 (2004), 691-699. 
Szesztay 1959

Szőke 1995

Szőke-Vándor 1987

Tímár et al. 2010

Virág 1997

Wilkinson-Stevens 2003 Wilkinson, K. - Stevens, Ch.: Environmental archaeology - approaches, techniques and applications. Stroud, 2003.

Zatykó 2011
Szesztay K.: Tavak és tározómedencék vízháztartási jelleggörbéi Földrajzi Közlemények 8/2 (1959) 191199.

Szőke B.M.: Borderland of cultures. Settlement patterns in Hahót Basin (Aims, methods, results). In Antaeus - Communicationes ex Instituto Archaeologico Academiae Scientiarium Hungaricae 22. Ed: Török L. - Kovács L. - Redő F. - Solti J. Budapest 1995, 13-34.

Szőke B.M. - Vándor L.: Kísérlet egy táji egység történeti rekonstrukciójára (Versuch einer siedlungsgeschichtlichen Rekonstrukzion einer Region). Zalai Gyűjtemény 26 (1987), 83-100.

Tímár G. - Csillag G. - Székely B. - Molnár G. Galambos Cs. - Czanik Cs.: A Balaton legnagyobb kiterjedésének rekonstrukciója a függőleges kéregmozgások figyelembevételével. Földrajzi Közlöny 140/4 (2010) 455-462.

Tullner T. - Cserny T.: New aspects of lake level changes: Lake Balaton, Hungary. Acta Geologica Hungarica Vol. 46/2 (2003), 215-238.

Virág Á.: A Balaton múltja és jelene. Eger, 1997.
Zatykó Cs.: Integrált kutatások: a tájrégészet. In: Régészeti Kézikönyv. Ed: Müller R. Magyar Régész Szövetség, Budapest, 2011. 
Mellékletek 


\section{1. számú melléklet}

A Balatonkeresztúr-Réti-dűlőn végzett talajmechanikai fúrások kiértékelő adatlapjainak másolatai 


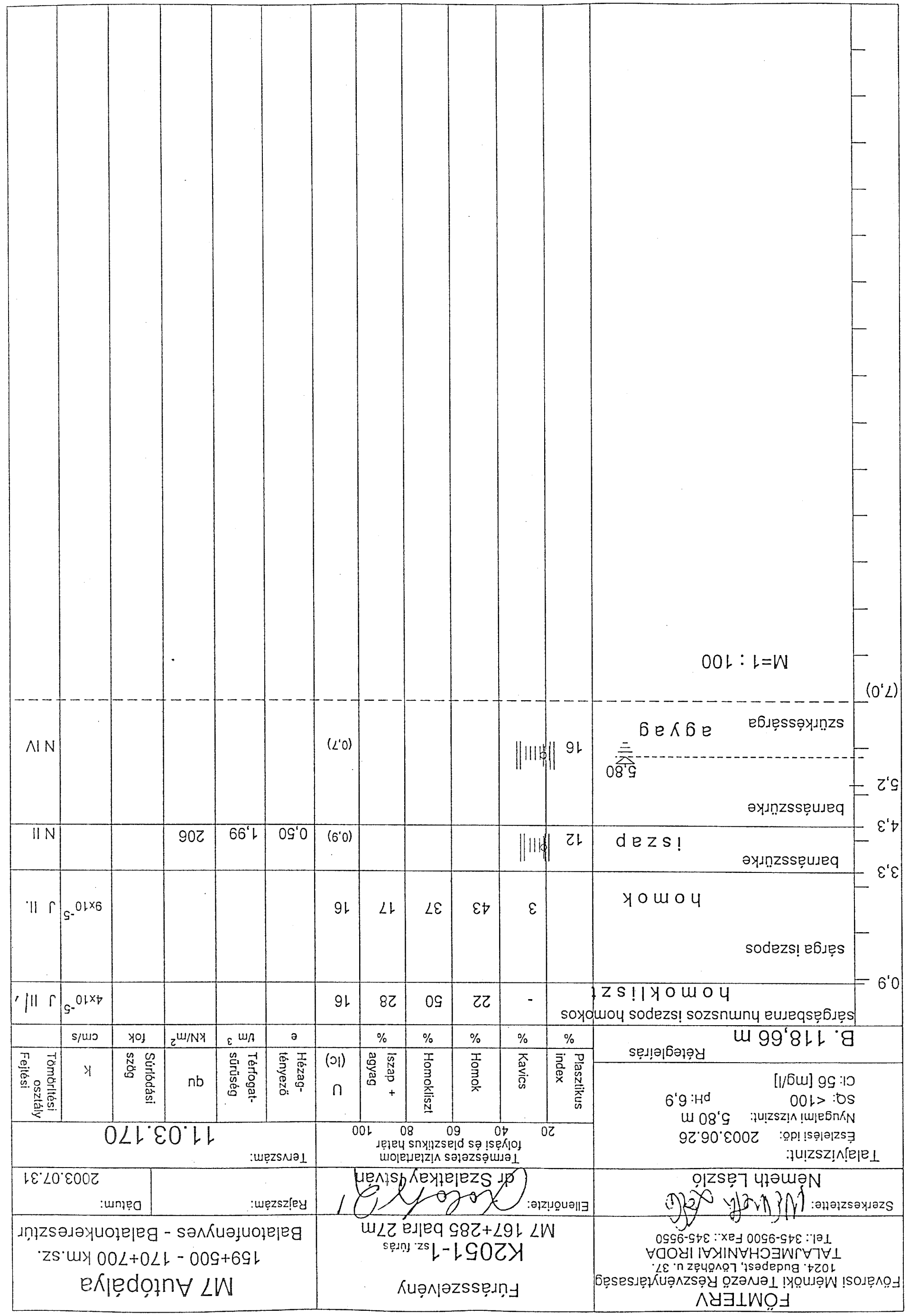




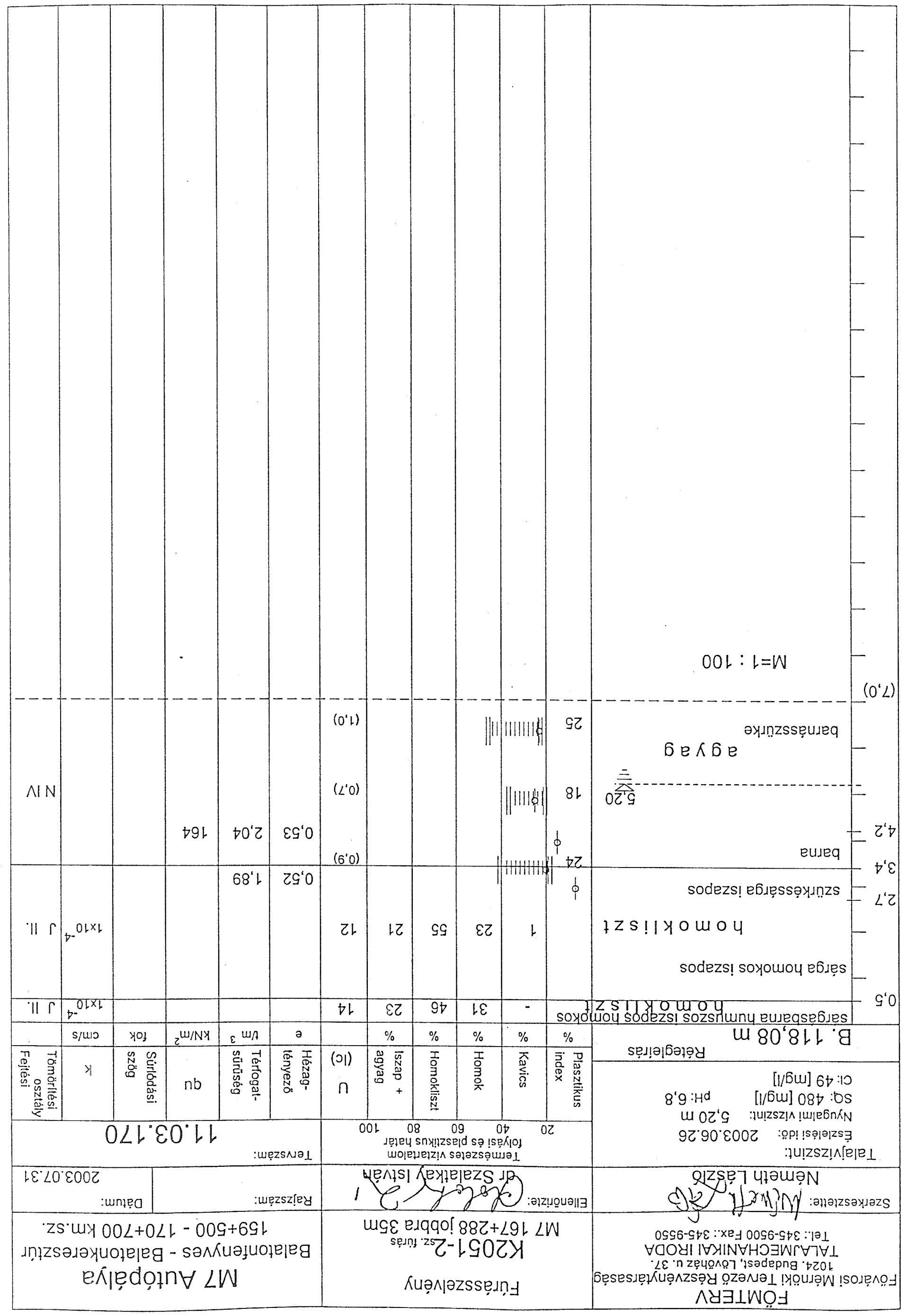


FURASSZELVENY

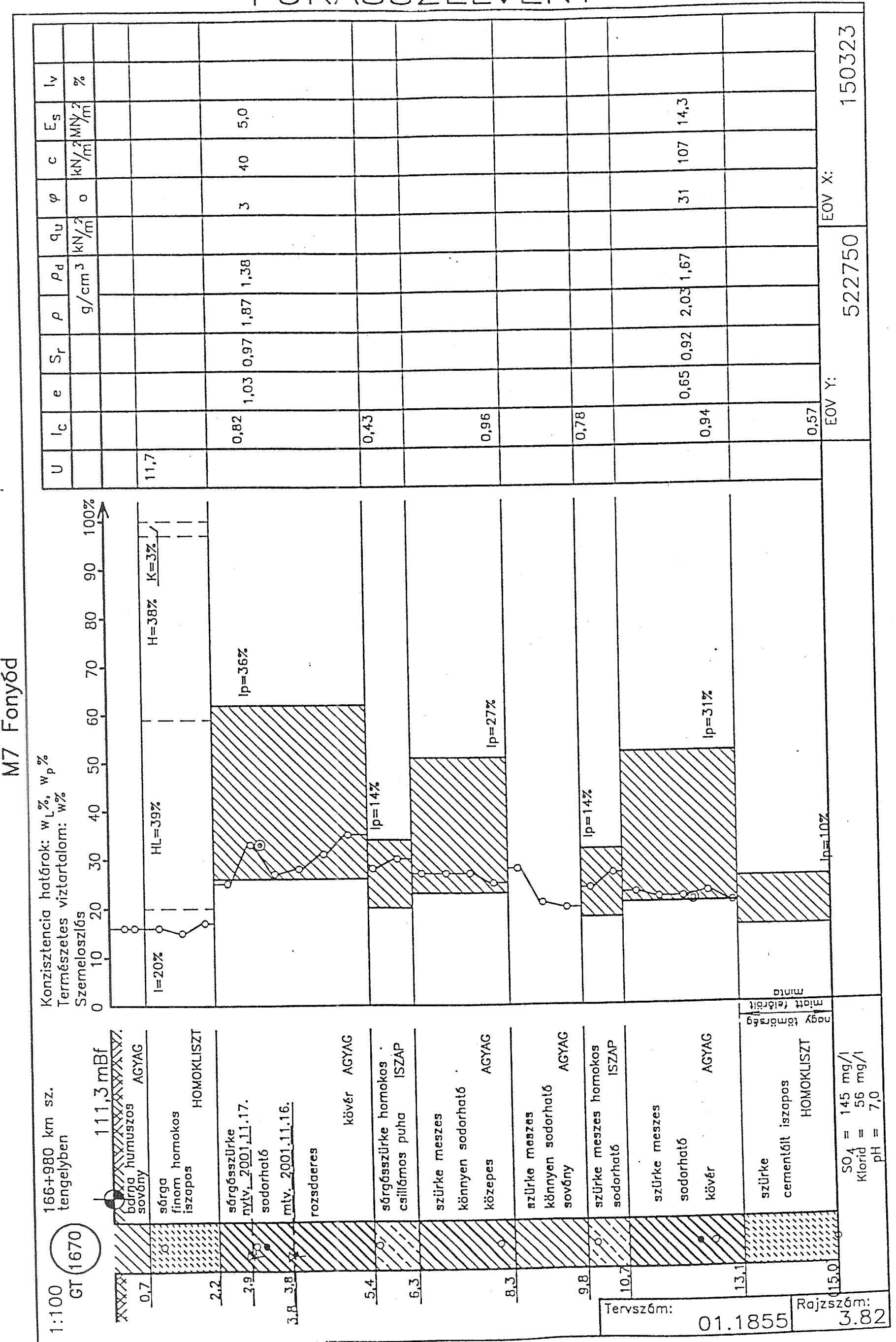




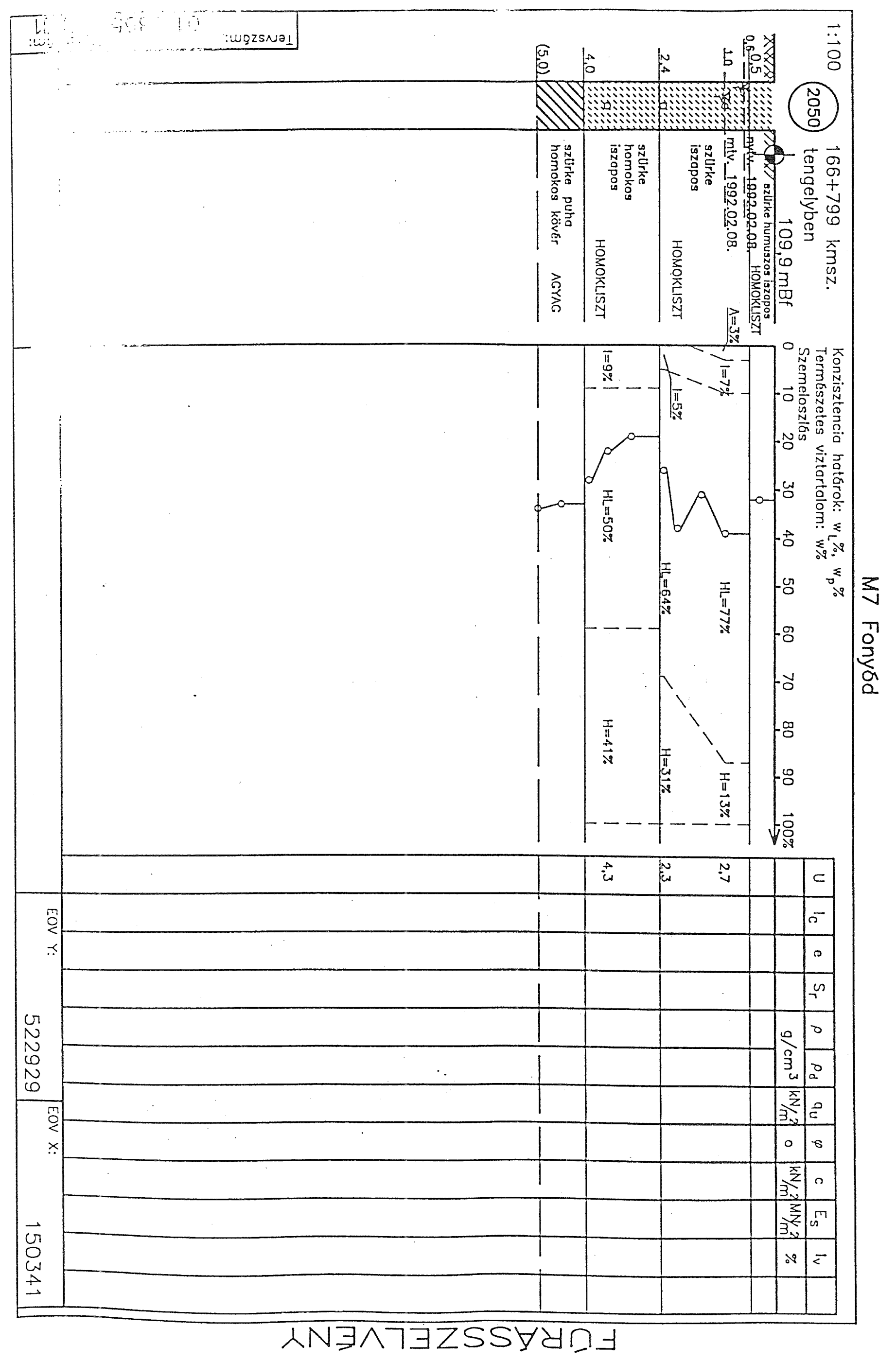




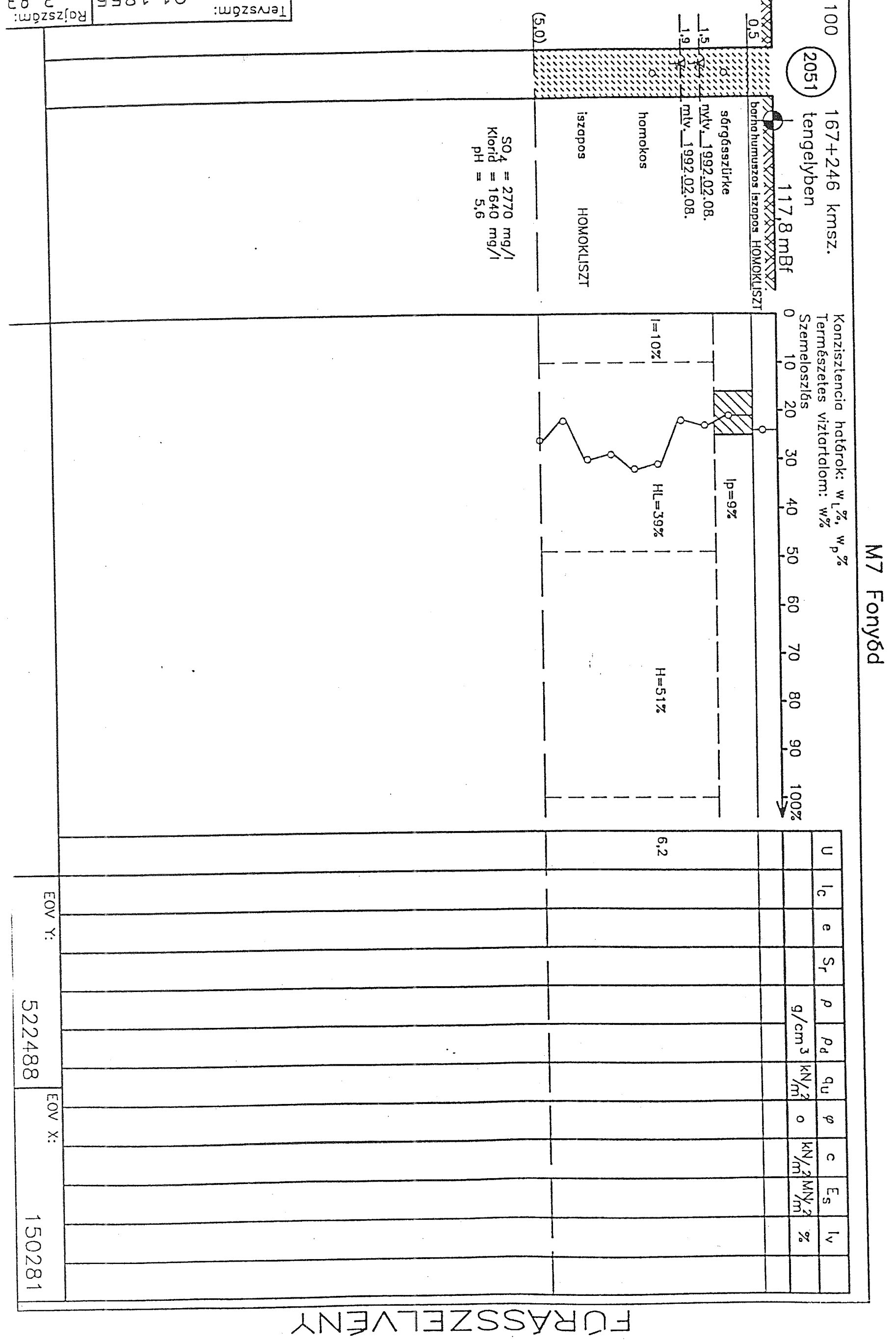




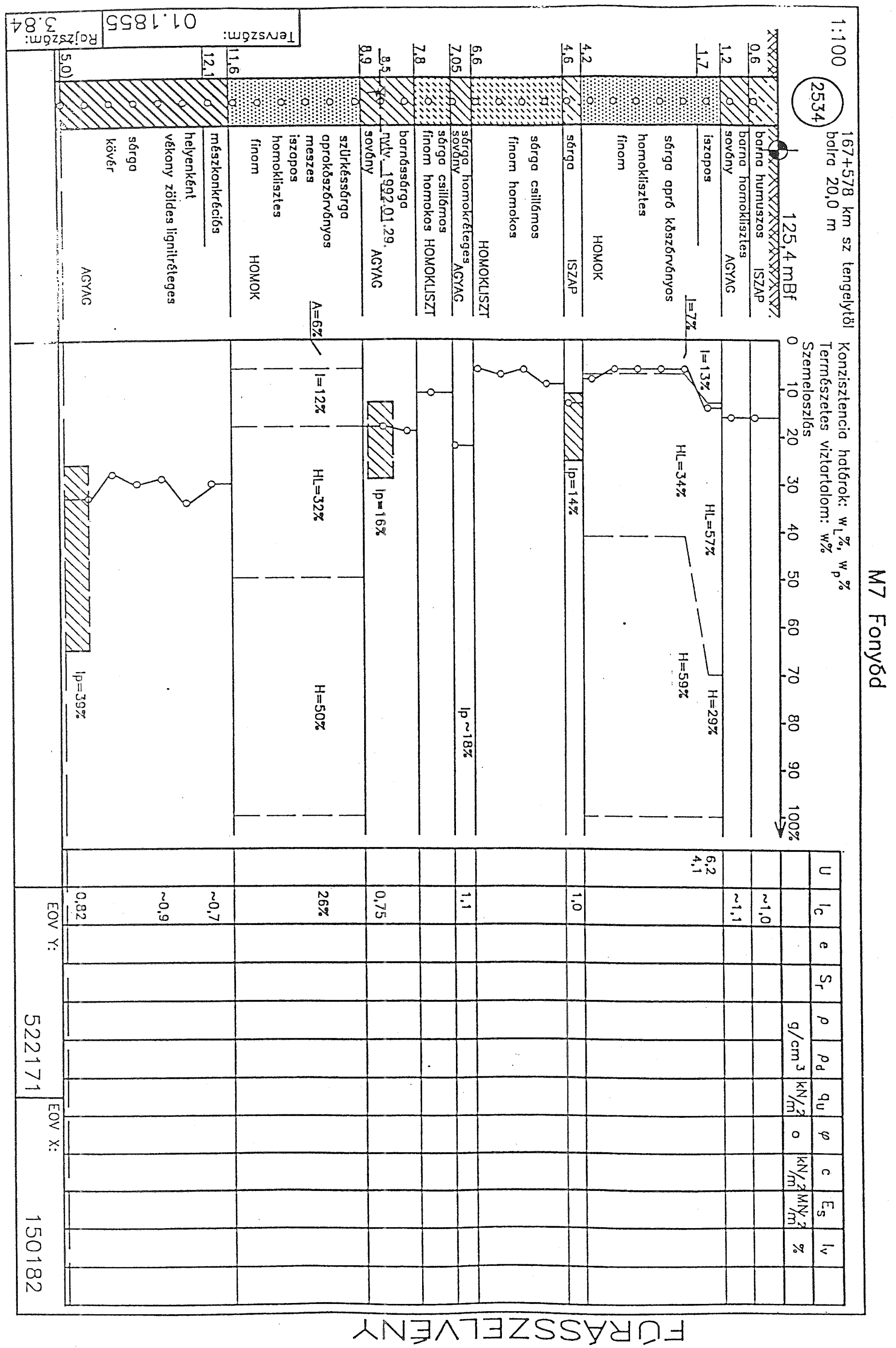




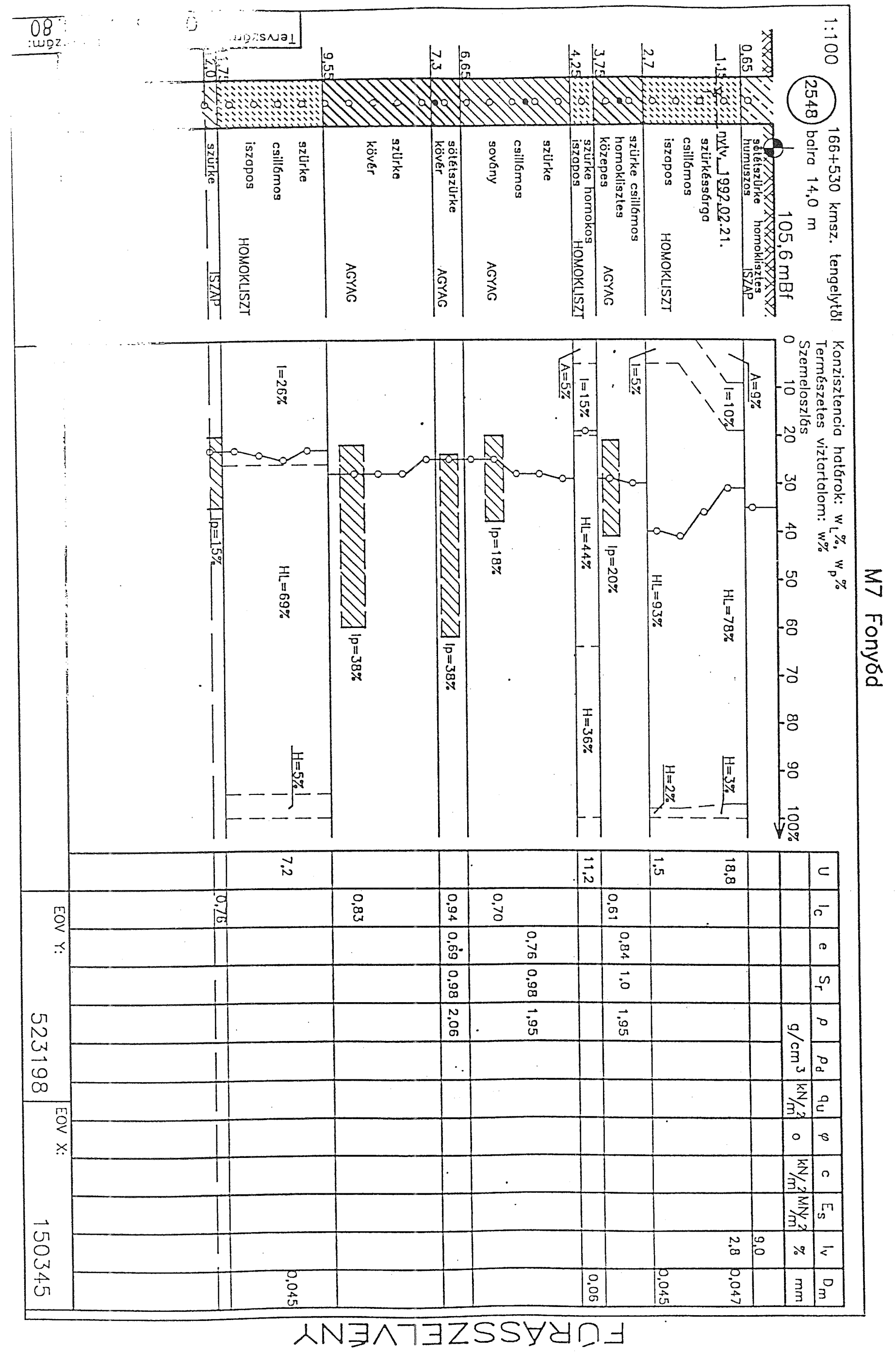




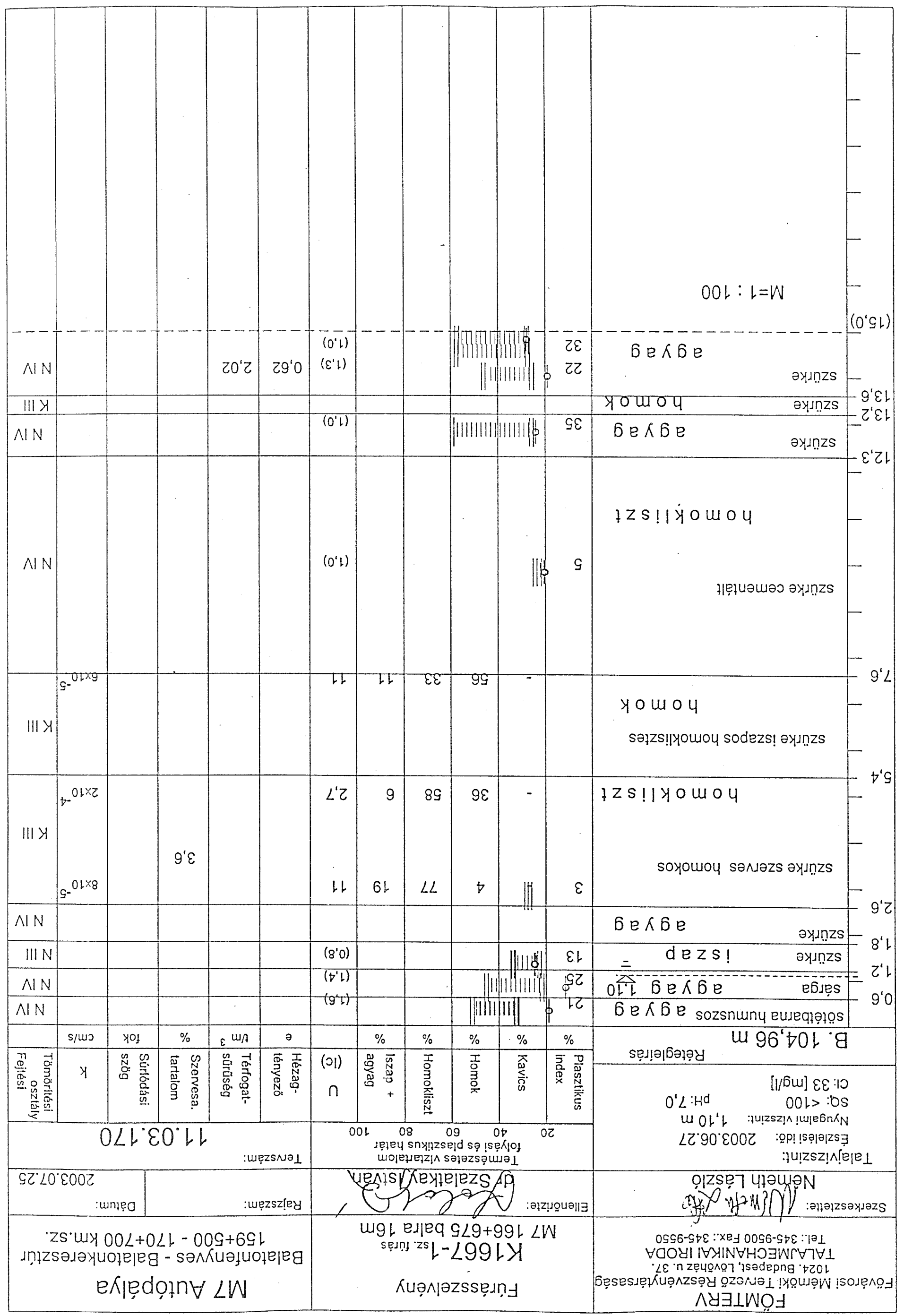




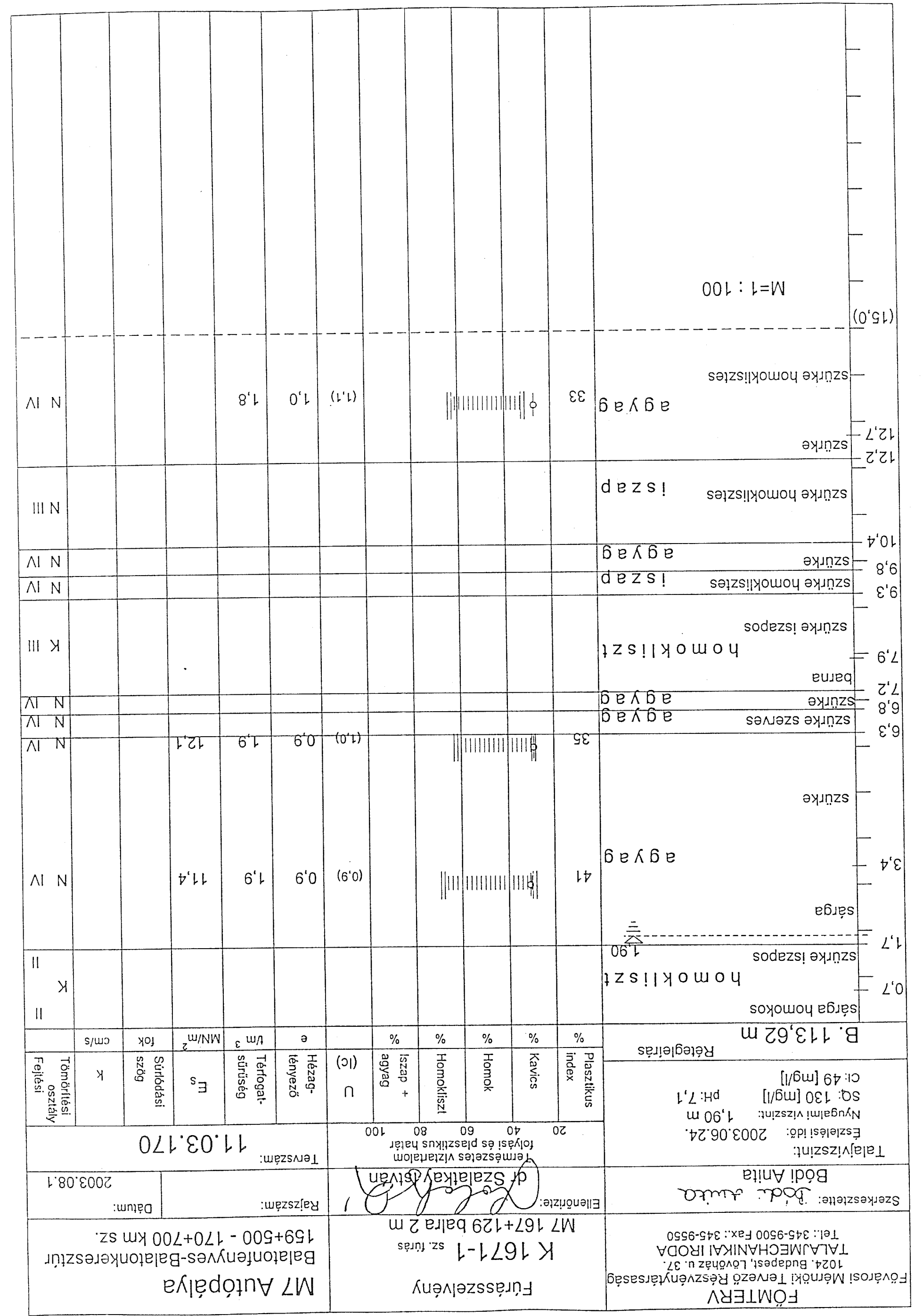




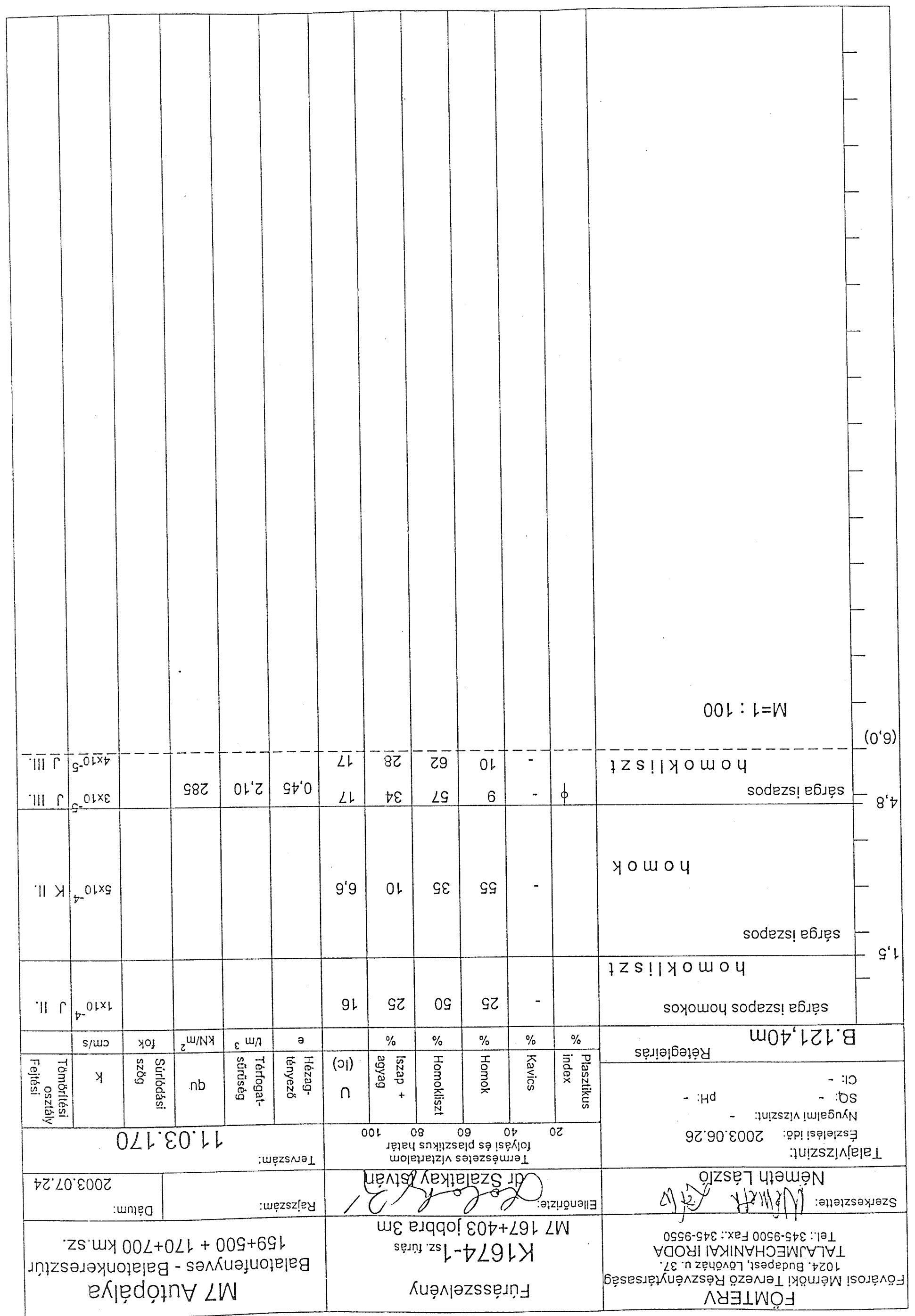




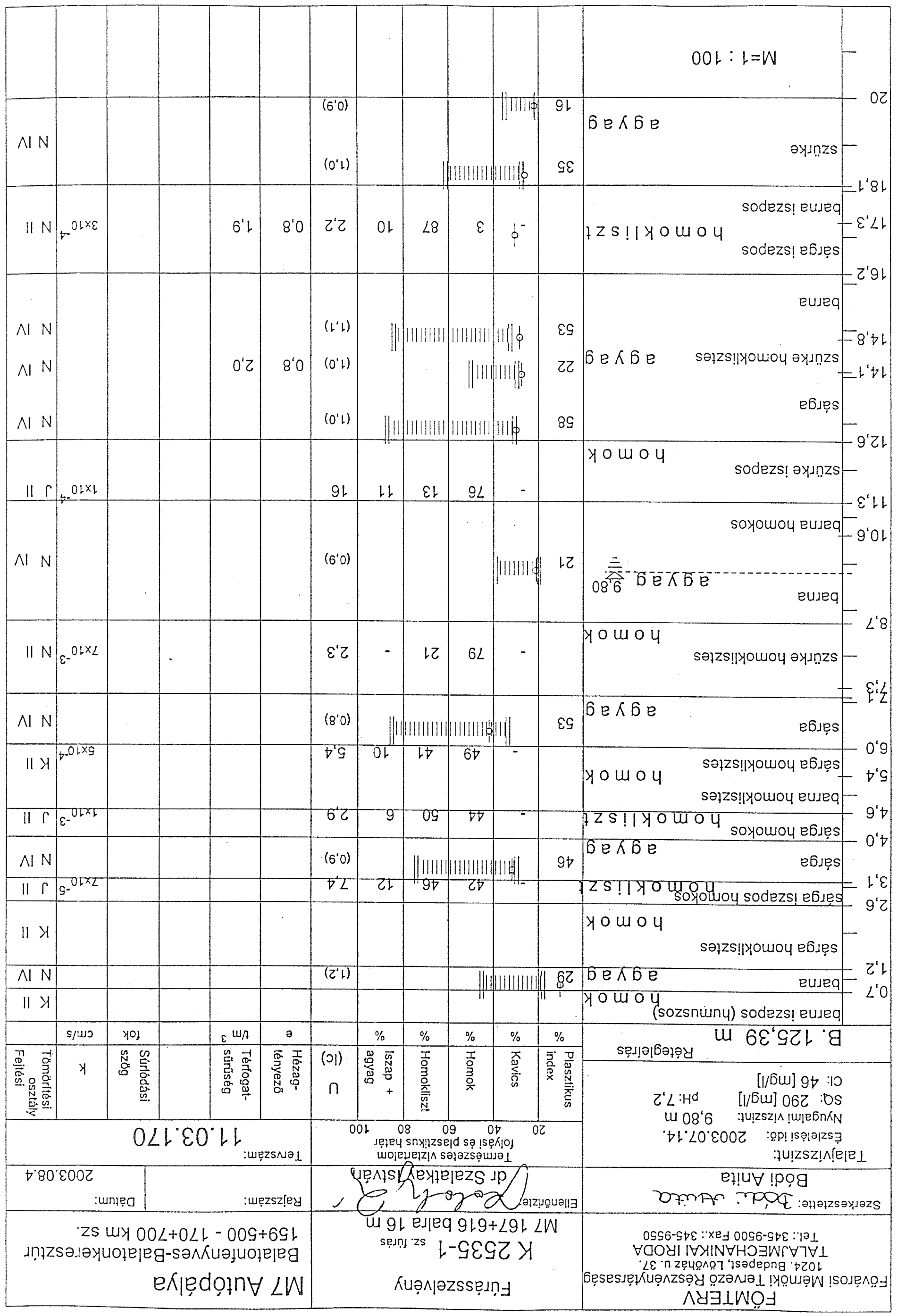




\section{2. számú melléklet}

A Balatinkeresztúr-Réti-dűlő közelében vett környezettörténeti mintasor pollenelemzésének eredményei 
Jelentés a balatonkeresztúri öblözet környezettörténei vizsgálatának eredményeiről

\section{Bodor Elvira $^{1}$ - Sümegi Pál ${ }^{2}$}

Bevezetés

2005 februárjában a Nagy-Berek balatonkeresztúri határában több térképező fúrás lemélyítését követően a Nyugati övcsatorna keleti partján zavartalan magfúrást mélyítettünk $1 \mathrm{e}^{3}$. A zavartalan magfúrás szelvénye a rétegsor kifejlődése: tőzegréteg, eutróf és mezotróf tavi üledék az eddigi radiokarbon adatokkal korolt balatoni szelvények alapján átfogta az utolsó 10.000 év fejlődéstörténetét, ezért részletes pollenanalitikai vizsgálatot végeztünk a területen. A pollenfeltárás Lycopodiumos módszerrel az SZTE Földtani és Öslénytani Tanszékének Geoarcheológiai és környezettörténeti laboratóriumában készült. A pollenvizsgálatokat Bodor Elvira végezte el, az általa leadott jelentést, kérésének megfelelően változtatás nélkül vettük be jelentésünkbe.

\section{Balatonkeresztúr palinológiai vizsgálatának eredményei}

A 8-280 centiméterig terjedő fúrás rétegei a késő Boreálisra, az Atlantikusra, a Szubboreálisra és a Szubatlantikusra jellemző asszociációt tartalmaznak. Az asszociáció szegényes fajszámmal képviselt. A taxon mennyiségi eloszlásában viszont nagyobb fluktuáció figyelhető meg. Ezek a mennyiségi változások egyrészt a hőmérséklet és a vízborítás változásainak hatására, másrészt lehetséges, hogy égés, vagy égetés következtében mentek végbe.

\section{Módszer}

A taxonokat a táblázaton és a TILIA diagramon a megjelenés sorrendjében tüntettük fel. A NAP esetében a vegetáció olyan gyérnek bizonyult, hogy csak az AP összpollenszámával együtt lehetett ábrázolni. Az AP és a vízi növényzet önmagában lett százalékolva. A százalékolás összpollenszámba a fusit, fungi és az epidermisz mennyiségét nem vettük be. A diagramokban a nagyon kis számban megjelenő, de fontos információt adó növényeket 10x-szeresére nagyítottuk fel, és a diagram többi részétől eltérően fekete színnel jelöltük.

\footnotetext{
${ }^{1}$ Magyar Állami Földtani Intézet nyugalmazott munkatársa

${ }^{2}$ MTA Régészeti Intézet és SZTE Földtani és Öslénytani Tanszék

${ }^{3}$ SZTE Földtani és Öslénytani Tanszék terepi kollektívája köszönetet mond Serlegi Gábor önköltséges PhD hallgatónak a terepi munkába nyújtott fizikai segítségért.
} 


\section{264-280 centiméter: Boreális szakasz}

A szárazföldi területen az elegyes lombos erdő uralkodik, amelyben a Corylus dominál. Szubdomináns a Quercus robur (kocsányos tölgy), majd az Ulmus jelentősebb. Az erdőbe Tilia cordata (kislevelü hárs) és kevés Tilia platyphyllos (nagylevelü hárs) is keveredik. Utóbbi az enyhébb telek jelzöje is lehet. (SIMON 1982). A szakasz végén a Corlyus visszahúzódik, ezzel párhuzamosan nő meg a Fagus és a Quercus robur mennyisége.

A távolabbi területen a Pinus silvestris és a Picea gyérebb állományai lehettek. A Pinus mennyisége 272 centiméterben hirtelen lecsökken, párhuzamosan a Picea állományának növekedésével A Pinus állománya felmelegedés hatására ritkulhat meg (KOMLÓDI 1969).

Lágyszárú aljnövényzetben az Artemisia vulgaris (fekete üröm) domináns, mellette már megtalálható a Compositae, Pteridinium, melyek már humán befolyásra is utalhatnak (VAN GEEL 1978). A Pteridinium ugyan még nem jelez agrártevékenységet, de általában kiterjed az erdőkivágások után. (BRONGES 1972). A humán befolyást támasztja alá az is, hogy következetesen jelen van a Filipendula amely legeltetésre és 256 centiméterben a Chenopodium album (fehér libatop) is amely preagrár tevékenységre utalhat (TAYLOR-GRIFFITHS-PEDLEY 1994).

A vízpart szélén bár szórványosan, de megjelennek a galéria erdő képviselői: Salix fragilis (törékeny füz), és az Alnus.

A vízi élettérben az algaszervezetek között a mezotrof vizeket kedvelő Botryococcus braunni zöld alga uralkodik, és megtalálható a mezotroftól eutrofig terjedő trofitású nyitott vizekben tenyésző, Zygnema, sőt a Sphagnum palustre is.

A nyíltvízi hínárok között a mélyebb és ugyancsak mezotrof vizekben elöforduló Potamogeton natans (úszó békabuzogány) és a Myriophyllum verticillatum (gyürüs süllőhínár) uralkodik (SOÓ 1973).

A nyíltvíz körül gazdag mocsári és vízparti növényzet alakul ki, Phragmites, Sparganium erectum (ágas békabuzogány), Scirpus, Rorippa, Carex, Galium palustris (mocsári galaj) képviseletében.

A vegetáció a Boreális kései szakaszára jellemző, amelyet a Balatoni sekélyfúrásokhoz hasonlóan Corylus /Quercus dominancia jellemez.

\section{184-264 centiméter: Atlantikus}

A szakasz egy korai (192-264 centiméter) és egy kései (192-136 centiméter) időszakra osztható. 


\section{2-264 centiméter: Atlantikus 1}

A szakasz kezdetén 256 centiméterben: a Quercus dominánsá válása mellett a Fagus silvatica felszaporodása jellemző. A szakasz középső részétől a Carpinus, és a Betula pendula (közönséges nyír), mellett a Betula pubescens (szőrös nyír) is megjelenik.

A szárazföldi környezetben megtalálható a Filipendula és a Juncus is, utóbbi képviselheti az ember által a természetes környezet megzavarását. Emberi tevékenység jele lehet a Riccia terjedése is (VAN GEEL 1981). A humán tevékenység növekedését támasztja alá, hogy a Chenopodium album száma is növekedik.

A vízpartot az Alnus glutinosa (enyves éger) felszaporodásával már galériaerdő kíséri. Az algák között a Boreálisban uralkodó mezotrof Botyococcus dominanciát a nagy ökológiai türőképességü Pediastrum boryanum (SEBESTYÉN 1968/b) veszi át. A szakasz kezdetén ismét megjelenik a Zygnema A hínárok között terjed az eutrofabb vizekben tenyésző Stratiotes aloides ( (POMOGYI 1989).

240 centiméterben a legeltetésre utaló Filipendula mellett megtalálható a Poa pratensis (réti perje) is. A Gentiana terjedése változó, amely alacsony talajvízszintet jelölhet a nyári és az őszi időszakban (OBERDORFER 1970). Megjelennek a Sphagnum lápokban előforduló zygospórák, oospórák, és Cladocerák, amelyek alacsonyabb 4-6 pH-jú vizekben találhatók, de alacsony bázikus mezotrof sekély vizekben is előfordulnak.

Így az Alona rustica, amely föként hidegebb időszakban terjed alacsony $\mathrm{pH}$ jú vizekben, a Closterium idiosporum, amely többé-kevésbé mezotrof szintén alacsony 4-6 pH-jú vagy enyhén bázikus nyílt vizekben található. Nem szükségszerüen kell, hogy Sphagnummal együtt forduljon elö. Elkerüli a relatíve meleg helyeket, előnyben részesíti a mérsékelt zónákat. A nyílt vízből ekkor eltünik a Potamogeton ami sekélyesedést is jelenthet.

232 centiméterben a szárazföldi élettérben a következetesen előforduló Chenopodium album mellett megjelenő Rumex, Althea, és Plantago major (nagy útifü) bolygatott, taposott területre utalhat. A Hedera helix pedig már a klimaoptimumot jelenti (IVERSEN 1944/a).

A vízi élettérben megjelenik a Penium zygospóra, amely kezdődő Sphagnum lápokban található Ugyanakkor rövid idöre eltünnek a kifejezetten eutof Rannunculus-ok.

224 centiméterben hirtelen ismét felszaporodik a Zygnema és mellette ismét megjelenik a Sphagnum palustris. A vízi élővilágot alkotók olyanokból állnak amelyek mezotroftól-eutrofig terjedő trofitású vizekben találhatók. 
Így az Eurycerus lamellatus, amely sekély, eutrof relatíve meleg, gazdag szerves anyag tartalmú vizekben fordul elö. A Cosmarium controversum pedig mezotroftól-eutrofig terjedő trofitású vizekben található. A Riccia felszaporodás is megfigyelhető. A Riccia mellett a Rumex, Althea gyomtársulások tagjai is megtalálhatók

A vízi élettérben a nyíltvízi, Myriophyllum felszaporodik, valamint újból megjelenik a Potamogeton.

200-216 centiméterben a szárazföldi környezetben megjelenő Allium föként száraz gyep és útszéli gyomtársulásokban, de lápokban is elöfordulhat.

A vízi élettérben a nyíltvízi hínár a Myriophyllum, és a vízpartiak terjednek (Sparganium ercetum, Rorippa,) .

192 centiméterben: az agrártevékenység intenzívvé válik. Megjelenik a Tritichum és az Avena is.

192-136 centiméter: Atlantikus 2

184 centiméterben a határt a Quercus robur számának hirtelen lecsökkenése jelöli ki. Rövid időre ismét a Corylus dominál. A Corylus ismételt előtérbe kerülését okozhatja a nedvesség változása, ezeket a változásokat 200-260 évenkénti ciklusokra teszik (AABLY, 1976 VAN GEEL 1978). A Quercus hirtelen csökkenése talajvízcsökkenés hatására is történhet, amit alátámaszthat az Ulmus, Alnus, Betula megritkulása és a Gentiana terjedése. Lehetséges az is, hogy az elegyes lombos erdő ritkulásában az emberi hatás is szerepet játszhatott, mivel az agrártevékenység növekedik, a Tritichum és Avena mellett már az Aegilops is megtalálható.

A vízszint rendkívül sekély, vízparti vegetáció uralkodik. A nyíltvíziek közül csak a Myriophyllum következetes. A vízi élettérben ismételt lápi hatások érvényesülnek, újból megjelenik a Sphagnum és a Sphagnum lápokban jellemzö Tilletia sphagni. Söt fellép a Pediastrum simplex is amely szerves anyagban gazdag eutrof vizekben gyakori.

176 centiméterben ismét a Quercus dominál. A földmüvelés tovább folytatódik, és kisebb mélyülést jelenthet a Potamogeton natans megjelenése.

136-168 centiméterben a talaj vízszint és a humiditás növekedését jelentheti az Ulmus, Betula, Carpinus terjedése. A fás növényzetben megjelenik a 
Castanae is. A kultivált gabonafélék mellett ismét megjelenik a legeltetésre utaló Filipendula és a Plantago lanceolata (lándzsás útifü).

A vízi környezetben a Pediastrum és a nyíltvízi Myriophyllum száma is növekszik. A Pediastrum zöldalga növekedése is nedvesebb csapadékosabb periódusokhoz kapcsolódik (MORZADEC-KERFOURN 1988). Gyakorisága szezonális is lehet.

\section{104-136 centiméter Szubboreális}

A szakaszt egyrészt az Ulmus (VAN GEEL 1978) Betula, Carpinus a Quercus számának nagyarányú csökkenése jelöli ki.

128 centiméterben a lágyszárúak között emelkedik a Gentiana száma és eltűnnek a földmüvelésre és legeltetésre utaló növények képviselői.

120 centiméterben a vegetáció rendkívül megritkul. A vízi élettérben csak a nagyon sekély vízre utalók maradnak meg (Ranunculus, Cyperaceae). Hirtelen megnövekszik az égésre vagy égetésre utaló fusitok száma .

112-104 centiméterben továbbra is dominálnak az égésre utaló jelek, de, már némileg növekszik az elegyes lombos erdő (a Fagus, Quercus és a Carpinus) kiterjedése.

A lágyszárú aljnövényzet nagyon gyér, valószínűleg csak az erdők aljnövényzetét alkotó páfrányok találhatók.

A vízi környezetben a Pediastrum, a Myriophyllum, Ranunculus mennyisége hirtelen növekszik. Ismét egy csapadékosabb időszak valószínüsíthető ?

\section{8-104 centiméter Szubatlantikus}

A klíma és ennek következtében a vegetáció változás hatására Szubatlantikus 1-re (32-104 centiméter) és Szubatalntikus 2-re (8-32) osztható.

\section{2-104 centiméter Szubatlantikus 1}

88-96 centiméterben rendkívül erőteljes vegetációritkulás következik be, így a réteg hovatartozását biztosan nem lehet megállapítani. A fás növényzet majdnem eltünik, csak 1-1 db Fagus, Betula, Corylus található. A Fagus jelenléte és a Quercus hiánya a rétegnek a Szubatlantikusba tartozását valószínúsíti. A lágyszárú aljnövényzetben a Trifolium, Poa pratensis, 
Plantago nem zárja ki a humán aktivitást.

Drasztikusan lecsökken a Pediastrumok száma. A vízi környezetben néhány, föként eutrof hatásra utaló növény fordul elö (Oenanthe aquatica, Ranunculus).

Az égésre utaló fusitok mennyisége rendkívül magas, ezzel párhuzamosan nő gomba spórák és a növényi szövetmaradványok mennyisége is.

80 centiméterből vett rétegben a szórványosan előforduló (1-1 db) fás növényzetben a Fagus dominál. A szárazföldi alj és a vízi növényzet is rendkívül ritka.

Nyíltvízi növények már nem fordulnak elö. A Pediastrum pedig teljesen eltünik a vegetációból Megtalálható viszont a Sphagnum láposodás kezdeti szakaszára jellemző Penium zygospóra. A fusit, gomba és epidermisz az előző két réteghez hasonlóan nagy mennyiségben fordul elö.

72 centiméterben a fusitok mennyisége hirtelen lecsökken. Az elegyes lombos erdő újra elterjed, amelyben a Fagus silvatica dominál, és a Quercus robur szubdomináns. Az aljnövényzet továbbra is rendkívül gyér.

A vízi környezetben újból megjelennek a nyíltvízi növények, valamint jelen van a Zygnema, és a Penium zygospóra is.

40-64 centiméter közötti szakaszban nagyarányú a fusit mennyisége, a vegetáció viszont nagyon gyér. A lágyszárúak között ismét megtalálható a legeltetésre utaló Plantago lanceolata, de ez a taxon nem minden esetben jelent humán befolyást, megjelenése lehet változó klíma eredménye is (VAN GEEL 1978).

A vízi környezetben megtalálható a Closterium idiosporum, és a Cosmarium amely mezotroftól-eutrófig terejdő trofitású vízekben fordul elő.

\section{8-32 centiméter Szubatalntikus 2}

Ebben a rétegben is nagymennyiségü fusit, gomba, és epidermisz található, de már kissé felszaporodik a fás vegetáció, a Quercus robur, Fagus silvatica és a Betula pubescens. Nedvesebb, melegebb, időszak valószínúsíthető, amit alátámaszt, hogy a Corylus már csak szórványosan fordul elő, és megjelenik a Lonicera.

Megtalálható a helyi antropogén hatás indikátora a Juglans (CRUISE 1990, ZÓLYOMI 1952). Az aljnövényzetben a gyomnövénynek számító Artemisia terjed. Megtalálható a Filipendula, Plantago a Linum perenne (évelő len), Centaurea cyanus (kék búzavirág) és a termesztett növények között a Secale is. 
A vizi környezetben az algaszervezetek között a Spirogyra terjed, amelynél $20^{\circ} \mathrm{C}$ feletti, de a legtöbb fajnál $14-22{ }^{\circ} \mathrm{C}$ közötti hömérséklet az optimum. Nyitott eutrof vízet jelez. Ugyanakkor megtalálható a Sphagnum lápokra jellemző Tilletia sphagni is.

Összefogalva:

A 8-280 centiméterig terjedő balatonkeresztúri fúrás a késő Boreálisra, Atlantikusra, Szubboreálisra és Szubatlantikusra jellemző asszociációt tartalmaz.

A késő Boreálisban elegyes lombos erdő uralkodik, már megtalálhatók a preagrár tevékenységre, az erdőirtásra és a legeltetésre utaló növények: (Pteridinium, Chenopodium album, Filipendula, Juncus).

A vízboritás mezotrof, bár nyílt (Myriophyllum, Potamogeton natans) de százalékosan még nem értékelhető. A tavi vízborítás Sphagnum láppal lehetett összekötetésben, vagy a tó körül alakulhatott ki kisebb láp.

Az Atlantikus 1-ben az elegyes lombos erdő új taxonokkal gazdagodik. Megjelennek a bolygatott, taposott területekre utaló növények (Rumex, Plantago major, Althea).

Később az Atlantikus 2-ben a kultivált gabonafélék (Triticum, Avena, Aegilops) már intenzív agrártevékenységre utalnak.

A víz trofitása növekszik, jellemzők a lápokban előforduló zygospórák, oospórák, Caldocerák, de időnként feltủnik a Sphagnum is. A nyíltvízre jellemző hínárok száma felszaporodik.

A Szubboreálisban hirtelen megnövekszik az égésre, vagy égetésre utaló fusitok, valamint az epidermisz töredékek, és a gomba spórák száma ezzel párhuzamosan a szárazföldi és vízi vegetáció is rendkívül megritkul. A fás növényzet csaknem teljesen eltünik. A földmüvelésre és legeltetésre utaló növények is eltünnek. A vízi élettérben csak nagyon sekélyvízre utalók maradnak meg.

A Szubatalntikus 1-ben nyíltvízi növények már nincsenek, a Pediastrum is kihal. A vízi növényzet tovább ritkul, ezért százalékos kiértékelése ismét nem lehetséges.

A szárazföldi vegetáció is rendkívül gyér. Viszont újból megjelennek a legeltetésre utaló növények (Trifolium, Filipendula, Plantago lanceolata).

A Szubatlantikus 2-ben melegebb időszak valószínüsíthető. Néhány elegyes lombos fa is megjelenik, Quercus dominanciával. A legeltetésre utalók 
mellett újból megtalálhatók a fölmüvelésre utalók is (Cenaturea cyanus, Linum, Secale). A vízborítás eutrof, sekély, a lápi hatás továbbra is érvényesül.

Irodalom:

Aably, B. (1976): Cyclic climatic variations in climate over the past 5,500 years reflected in raised bogs. - Nature 263 281-284.

Bronges, J. A. (1972): Vaasssen, een akkercomplex uit Ijzertijd - Archeol. Monum. Ned. 3. 1-20. (Bussum).

Crusie, G.M. (1990): Pollen stratigraphy of two Holocene peat site in the Ligurian Apennines, northern Italy - Review of Palaeobotany and Palynology 63. 299-313.

Iversen (1944/a): Viscum, Hedera and Ilex as climate indicators. A contribution to the study of the post-glacial climate. - Geologiska Föreningens i Stockholm Förhandlinger 66. 463-483.

Járainé Komlódi, M. (1969): Adatok az Alföld negyedkori klíma és vegetáció történetéhez II. A klíma változása a Würm glaciális és a holocén folyamán palinológiai vizsgálatok alapján - Botanikai Közlemények 56. 43-55.

Morzadec-Kerfourn, M.T. (1988): Palaeoclimates and Palaeoenviroments from the Lateglacial to recent, in the Eastern Mediterranean East of the Nile Delta, the contribution of organicalled microfossils. - Paléoclimates et Paléoenvironnements Quaternaires 12. 267-275.

Oberborfer, E. (19870): Pflanzensoziologische Exkursionsflora für Süddeutschland. -Eugen Ulmer Stuttgart, 987.

Pomogyi, P. (1989):Macrophyte communite of the Kis-Balaton reservoir. Symp. Biol. Hung. 38. Akadémiai Kiadó Budapest 505-513.

Sebestyén, O. (1968/b): Remains of Pediastrum kawraisky Scmidle (Chlorophyta, Protococcales) in the sediments of the Lake Balaton. Annal Biol. Tihany 35. 203-226. 
Simon, T. (1982): A magyarországi edényes flóra határozója. - Nemzeti Tankönyvkiadó, Budapest.

Soó, R. (1973): A magyar flóra és vegetáció rendszertani növényföldrajzi kézikönyve V. - Akadémiai Kiadó, Budapest.

Taylor, D. - Griffiths, H. - Pedley, M. - Prince, I. (1994): Radiocarbon dated Holocene pollen and ostracod sequence from barrage tufa- dammed fluvial systems in the Whites Peak, Derbyshire, UK. - The Holocene 4.4. 356-364.

Van Geel, B. (1978): A palaeoecological study of Holocene peat bog sections in Germany and the Nethherlands. - Review of Palaebotany and Palynology 25. 1. 120.

Van Geel, B. - Bohncke, S.J.P. - Dee, H. (1980/81): A palaeoecological study of an Upper Late Glacial and Holocene sequence from „De Borchert", the Netherlands. - Review of Palaeobotany and Palynology, 31. 367-448.

Van Geel, B. - Hallewas, D.P. - Pals, J.P. (1982/1983): A Late Holocene deposit under the Westfriese Zeedijk near Enkhuizen (Prov. of NoordHolland, the Netherlands). Palaeoecological and archaeological aspects. - Review of Palaeobotany and Palynology 38 269-335.

Zólyomi, B. (1952): Magyarország növénytakarójának fejlödése asz utolsó jégkorszaktól. - MTA Biológiai Oszt. Közl. 1. 491-544. 


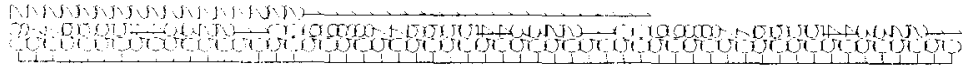
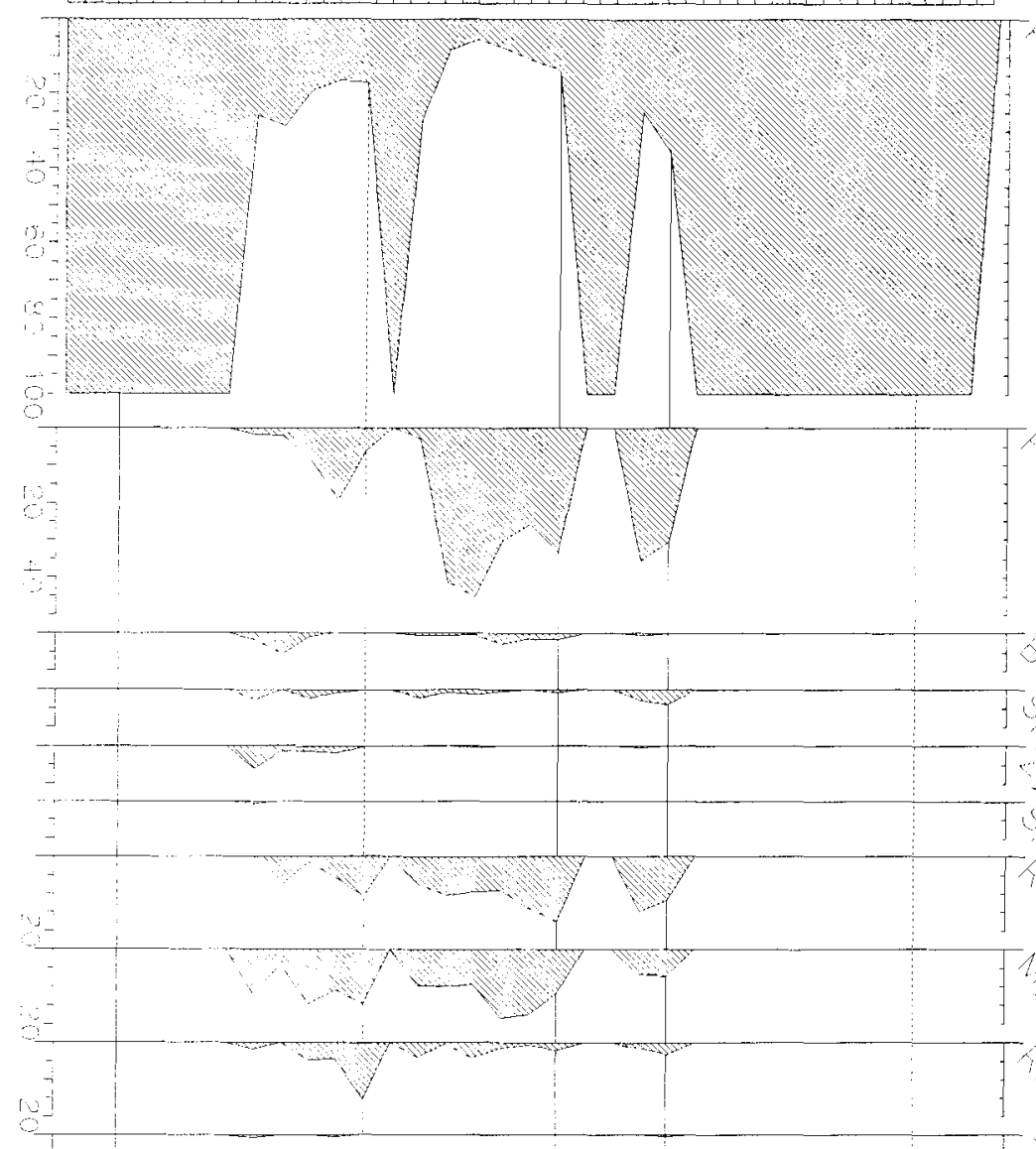

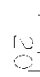
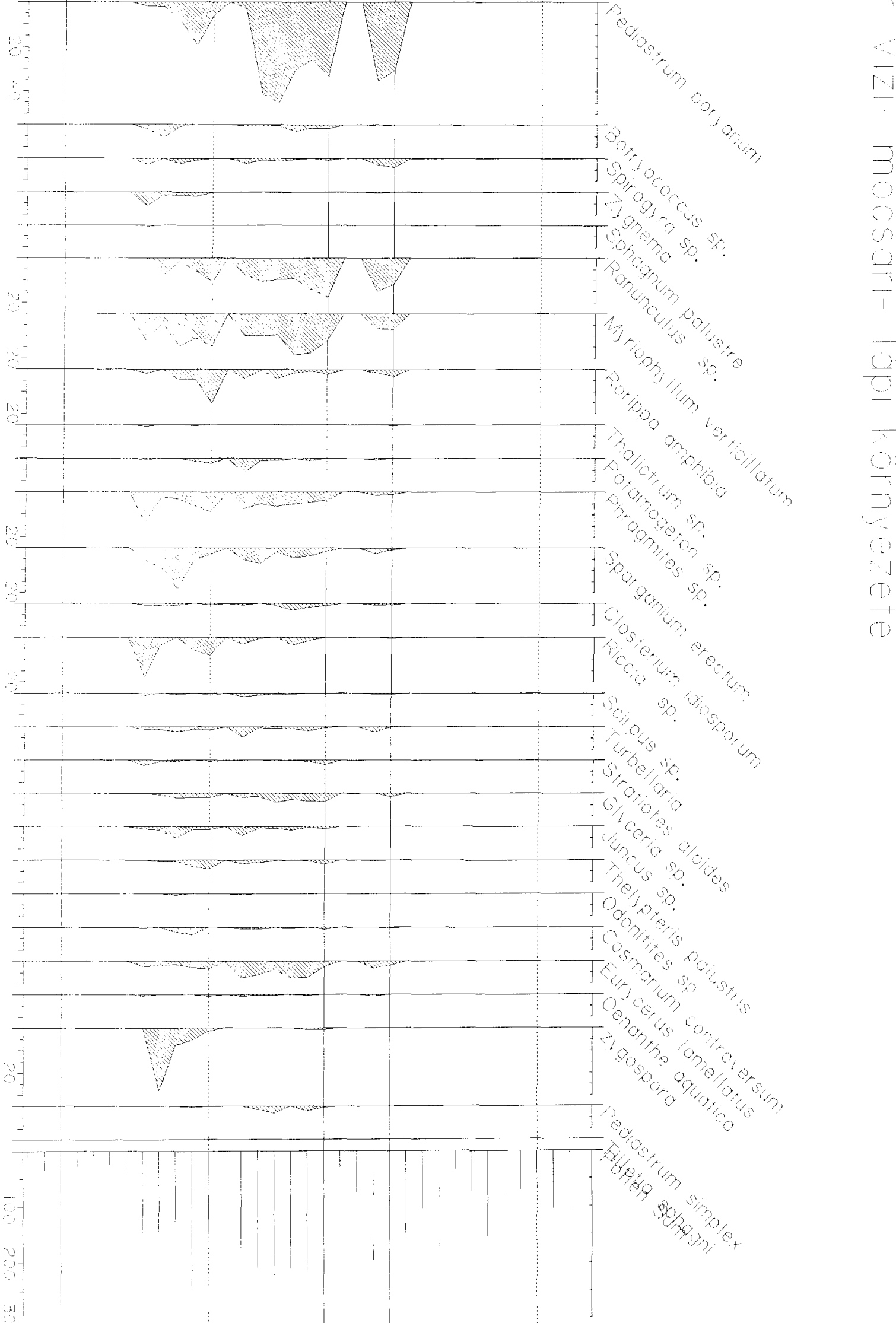

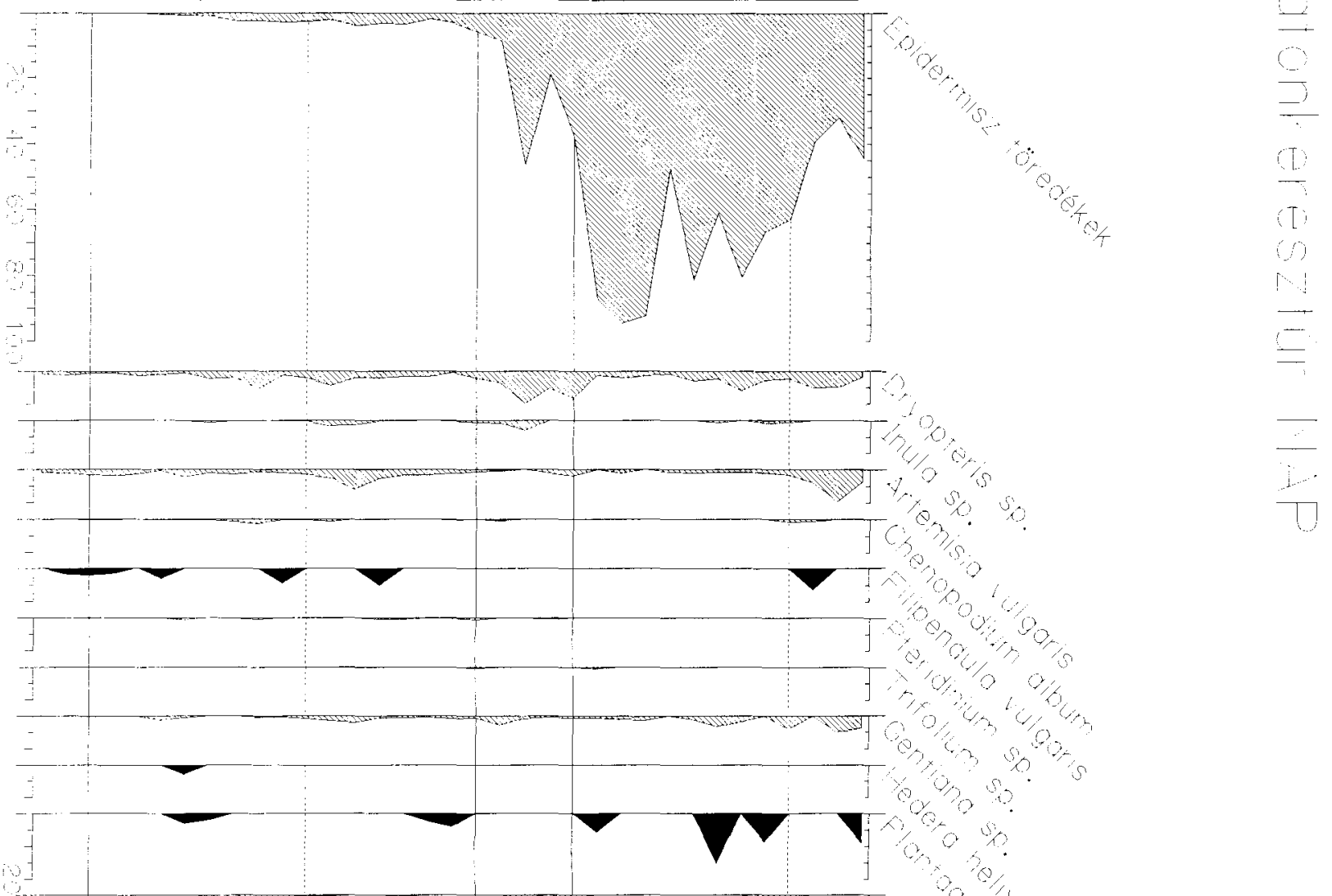


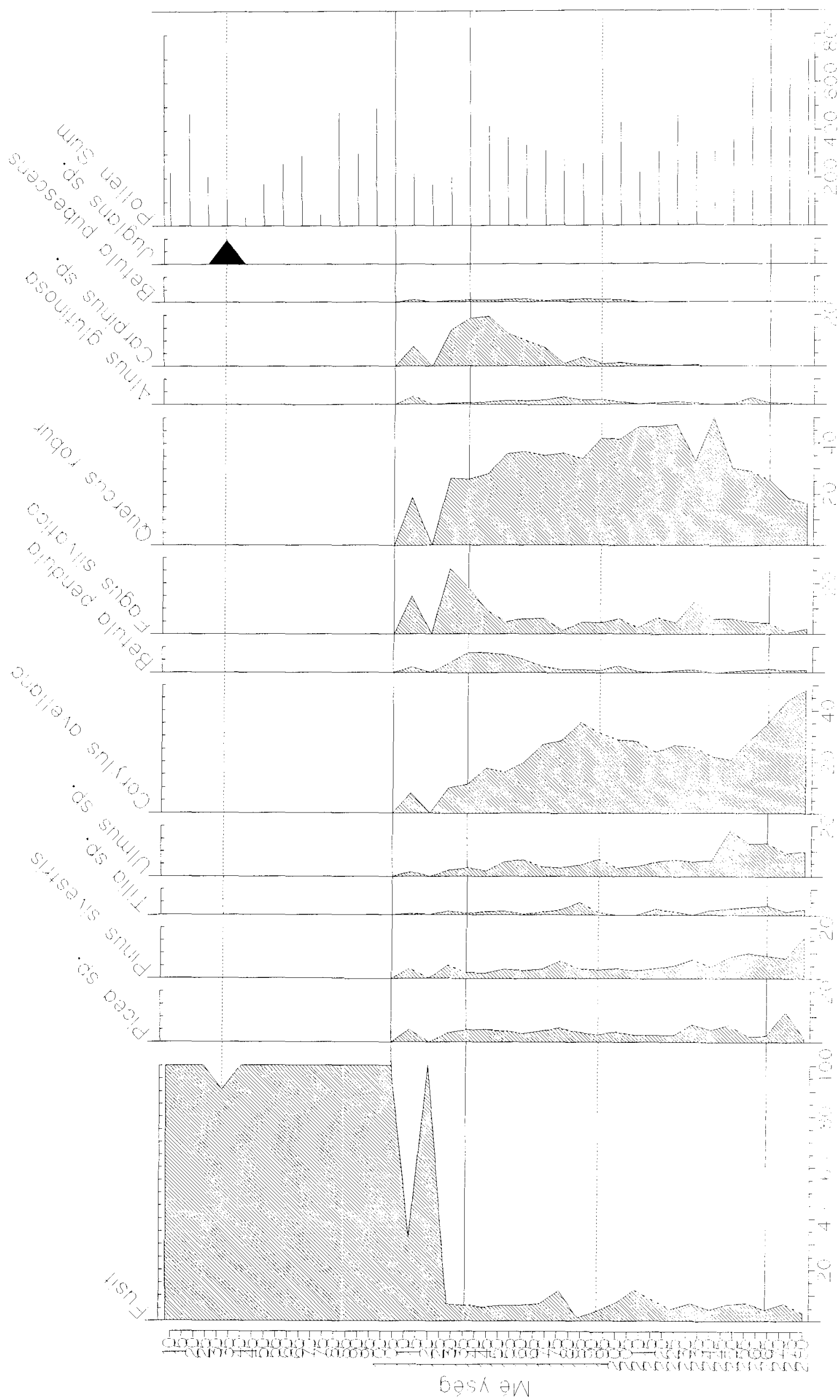




\section{3. számú melléklet}

A vizsgált terület régészeti lelőhelyeinek korszakonkénti összefoglaló táblázata 


\begin{tabular}{|c|c|c|c|c|c|c|c|c|c|c|}
\hline Lelőhely & $\begin{array}{c}\text { neolitikum } \\
\text { (Vonaldíszes } \\
\text { Kerámia k.) }\end{array}$ & $\begin{array}{l}\text { neolitikum- } \\
\text { kora rézkor } \\
\text { (Lengyeli k.) }\end{array}$ & $\begin{array}{c}\text { középső rézkor } \\
\text { (Balaton-Lasinja } \\
\text { k.) }\end{array}$ & $\begin{array}{l}\text { késő rézkor } \\
\text { (Badeni k.) }\end{array}$ & $\begin{array}{l}\text { kora bronzkor } \\
\text { (Somogyvár- } \\
\text { Vinkovci k.) }\end{array}$ & $\begin{array}{l}\text { kora bronzkor } \\
\text { (Kisapostagi k.) }\end{array}$ & $\begin{array}{c}\text { középső } \\
\text { bronzkor } \\
\text { (Mészbetétes } \\
\text { Kerámia k.) } \\
\end{array}$ & $\begin{array}{l}\text { késő bronzkor } \\
\text { (Urnamezős k.) }\end{array}$ & $\begin{array}{l}\text { késő vaskor } \\
\text { (La Téne C-D) }\end{array}$ & kora császárkor \\
\hline $\begin{array}{l}\text { Balatonkeresztúr } \\
\text { Csepp utca }\end{array}$ & & & & & $\mathrm{x}$ & & & & & \\
\hline $\begin{array}{l}\text { Balatonmagyaród } \\
\text { Brunner-sziget }\end{array}$ & $\mathrm{x}$ & & & & & & & $\mathrm{x}$ & & \\
\hline $\begin{array}{l}\text { Balatonmagyaród } \\
\text { Fenyvessziget }\end{array}$ & & $\mathrm{x}$ & & & & & & & & \\
\hline $\begin{array}{l}\text { Balatonmagyaród } \\
\text { Hídvégpuszta }\end{array}$ & $\mathrm{x}$ & $\mathrm{x}$ & $\mathrm{x}$ & $\mathrm{x}$ & $\mathrm{x}$ & $\mathrm{x}$ & & $\mathrm{x}$ & & $\mathrm{x}$ \\
\hline $\begin{array}{l}\text { Balatonmagyaród } \\
\text { Homoki-dúlő }\end{array}$ & & & $\mathrm{x}$ & & & & & & $\mathrm{x}$ & \\
\hline $\begin{array}{l}\text { Balatonmagyaród } \\
\text { Kányavári-sziget }\end{array}$ & $\mathrm{x}$ & & & $\mathrm{x}$ & & & & $\mathrm{x}$ & $\mathrm{x}$ & \\
\hline $\begin{array}{l}\text { Balatonmagyaród } \\
\text { Kiskányavár }\end{array}$ & & $\mathrm{x}$ & $\mathrm{x}$ & $\mathrm{x}$ & & & & & $\mathrm{x}$ & \\
\hline $\begin{array}{l}\text { Balatonmagyaród } \\
\text { Pörkölt-sziget }\end{array}$ & & & $\mathrm{x}$ & & & & & & & \\
\hline $\begin{array}{l}\text { Balatonmagyaród } \\
\text { Szarkavári-dúlő }\end{array}$ & & & $\mathrm{x}$ & & & & & & & $\mathrm{x}$ \\
\hline $\begin{array}{l}\text { Balatonmagyaród } \\
\text { Szarkavári-sziget }\end{array}$ & & $\mathrm{x}$ & $\mathrm{x}$ & & $\mathrm{x}$ & & & & $\mathrm{x}$ & $\mathrm{x}$ \\
\hline Balatonszentgyörgy & & & & & & & & & & $\mathrm{x}$ \\
\hline $\begin{array}{l}\text { Balatonszentgyörgy } \\
\text { Almási út }\end{array}$ & & & $\mathrm{x}$ & & & & & & & \\
\hline $\begin{array}{l}\text { Balatonszentgyörgy } \\
\text { Felüljáró }\end{array}$ & & & & $\mathrm{x}$ & & & & & & \\
\hline $\begin{array}{l}\text { Balatonszentgyörgy } \\
\text { Téglagyár }\end{array}$ & & & & & & & $\mathrm{x}$ & & & \\
\hline $\begin{array}{l}\text { Balatonszentgyörgy } \\
\text { Új utca }\end{array}$ & & & & & & & $\mathrm{x}$ & & & $\mathrm{x}$ \\
\hline $\begin{array}{l}\text { Balatonszentgyörgy } \\
\text { Vasútállomás }\end{array}$ & & & & $\mathrm{x}$ & & & & & & \\
\hline $\begin{array}{l}\text { Vörs } \\
\text { Borzás-dél }\end{array}$ & & & $\mathrm{x}$ & & & & & & & \\
\hline $\begin{array}{l}\text { Fónyed } \\
\text { Gólyásfa }\end{array}$ & & & & & & & & $\mathrm{x}$ & $\mathrm{x}$ & \\
\hline $\begin{array}{l}\text { Keszthely } \\
\text { Apátdomb }\end{array}$ & & & & $\mathrm{x}$ & & & & $\mathrm{x}$ & & \\
\hline
\end{tabular}

\section{Kis-Balaton medencéjének lelöhelyei}




\begin{tabular}{|c|c|c|c|c|c|c|c|c|c|c|}
\hline Lelőhely & $\begin{array}{c}\text { neolitikum } \\
\text { (Vonaldíszes } \\
\text { Kerámia k.) }\end{array}$ & $\begin{array}{l}\text { neolitikum- } \\
\text { kora rézkor } \\
\text { (Lengyeli k.) }\end{array}$ & $\begin{array}{c}\text { középső rézkor } \\
\text { (Balaton-Lasinja } \\
\text { k.) }\end{array}$ & $\begin{array}{l}\text { késő rézkor } \\
\text { (Badeni k.) }\end{array}$ & $\begin{array}{l}\text { kora bronzkor } \\
\text { (Somogyvár- } \\
\text { Vinkovci k.) }\end{array}$ & $\begin{array}{l}\text { kora bronzkor } \\
\text { (Kisapostagi k.) }\end{array}$ & $\begin{array}{c}\text { középső } \\
\text { bronzkor } \\
\text { (Mészbetétes } \\
\text { Kerámia k.) }\end{array}$ & $\begin{array}{l}\text { késő bronzkor } \\
\text { (Urnamezős k.) }\end{array}$ & $\begin{array}{l}\text { késő vaskor } \\
\text { (La Téne C-D) }\end{array}$ & kora császárkor \\
\hline \begin{tabular}{|l|} 
Keszthely \\
Belterület
\end{tabular} & & & & & & & & & $\mathrm{X}$ & \\
\hline $\begin{array}{l}\text { Keszthely } \\
\text { Fenékpuszta }\end{array}$ & $\mathrm{x}$ & & & $\mathrm{x}$ & & $\mathrm{x}$ & $\mathrm{x}$ & & $\mathrm{x}$ & \\
\hline $\begin{array}{l}\text { Keszthely } \\
\text { Gáti-domb }\end{array}$ & & & $\mathrm{x}$ & $\mathrm{x}$ & & & & $\mathrm{x}$ & $\mathrm{x}$ & \\
\hline $\begin{array}{l}\text { Keszthely } \\
\text { Halászcsárda }\end{array}$ & & & & $\mathrm{x}$ & $\mathrm{x}$ & & & $\mathrm{x}$ & & \\
\hline \begin{tabular}{|l} 
Keszthely \\
Halász-rét
\end{tabular} & & $\mathrm{x}$ & & $\mathrm{x}$ & & & & & & \\
\hline $\begin{array}{l}\text { Keszthely } \\
\text { Hévizi-öböl }\end{array}$ & & & & $\mathrm{x}$ & & & & & & \\
\hline $\begin{array}{l}\text { Keszthely } \\
\text { Honvéd utca }\end{array}$ & & & & $\mathrm{x}$ & & $\mathrm{x}$ & & & & \\
\hline $\begin{array}{l}\text { Keszthely } \\
\text { Hunyadi utca }\end{array}$ & & $\mathrm{x}$ & & & & & & & & \\
\hline $\begin{array}{l}\text { Keszthely } \\
\text { Méntelep }\end{array}$ & $\mathrm{x}$ & & & & & & & & & \\
\hline \begin{tabular}{|l|} 
Keszthely \\
Pusztatemplom
\end{tabular} & & & $\mathrm{x}$ & & & & & & & $\mathrm{x}$ \\
\hline $\begin{array}{l}\text { Keszthely } \\
\text { Római út }\end{array}$ & $\mathrm{x}$ & & & & & & & & & \\
\hline \begin{tabular}{|l|} 
Keszthely \\
Vámház
\end{tabular} & & & $\mathrm{x}$ & $\mathrm{x}$ & & & & & & \\
\hline \begin{tabular}{|l|} 
Keszthely \\
Zrinyi-utca
\end{tabular} & & $\mathrm{x}$ & & & & & & & & \\
\hline $\begin{array}{l}\text { Keszthely-Fenékpusza } \\
\text { Vasút }\end{array}$ & & & & $\mathrm{x}$ & & & & & $\mathrm{x}$ & \\
\hline $\begin{array}{l}\text { Keszthely- } \\
\text { Fenékpuszta } \\
\text { Vízügyi Itp. }\end{array}$ & & & $\mathrm{x}$ & & & & & & & \\
\hline Sármellék & & & & & $\mathrm{x}$ & & & & & \\
\hline $\begin{array}{l}\text { Sármellék } \\
\text { Agyagbánya }\end{array}$ & $\mathrm{x}$ & & $\mathrm{x}$ & & & & & & & \\
\hline \begin{tabular}{|l} 
Sármellék \\
Bekötőút
\end{tabular} & & & & & & & & $\mathrm{x}$ & $\mathrm{x}$ & \\
\hline
\end{tabular}

\section{Kis-Balaton medencéjének lelöhelyei}




\begin{tabular}{|c|c|c|c|c|c|c|c|c|c|c|}
\hline Lelőhely & $\begin{array}{l}\text { neolitikum } \\
\text { (Vonaldíszes } \\
\text { Kerámia k.) }\end{array}$ & $\begin{array}{l}\text { neolitikum- } \\
\text { kora rézkor } \\
\text { (Lengyeli k.) }\end{array}$ & $\begin{array}{c}\text { középső rézkor } \\
\text { (Balaton-Lasinja } \\
\text { k.) }\end{array}$ & $\begin{array}{l}\text { késő rézkor } \\
\text { (Badeni k.) }\end{array}$ & $\begin{array}{c}\text { kora bronzkor } \\
\text { (Somogyvár- } \\
\text { Vinkovci k.) }\end{array}$ & $\begin{array}{l}\text { kora bronzkor } \\
\text { (Kisapostagi k.) }\end{array}$ & $\begin{array}{c}\text { középső } \\
\text { bronzkor } \\
\text { (Mészbetétes } \\
\text { Kerámia k.) }\end{array}$ & $\begin{array}{l}\text { késő bronzkor } \\
\text { (Urnamezős k.) }\end{array}$ & $\begin{array}{l}\text { késő vaskor } \\
\text { (La Téne C-D) }\end{array}$ & kora császárkor \\
\hline $\begin{array}{l}\text { Sármellék } \\
\text { Devecseri-mező }\end{array}$ & $x$ & & & $x$ & & & & & & \\
\hline $\begin{array}{l}\text { Sármellék } \\
\text { Égenföld }\end{array}$ & & & & $x$ & & $x$ & & & $x$ & \\
\hline $\begin{array}{l}\text { Sármellék } \\
\text { Fenéki-út }\end{array}$ & $x$ & & & & & & & & & \\
\hline $\begin{array}{l}\text { Sármellék } \\
\text { Zalavári-domb }\end{array}$ & $\mathrm{x}$ & & & $x$ & & & & & & \\
\hline $\begin{array}{l}\text { Sármellék } \\
\text { Zalavári-határárok }\end{array}$ & & & $x$ & & & & & & & \\
\hline $\begin{array}{l}\text { Sávoly } \\
\text { Demjén-telep }\end{array}$ & & & $x$ & & & & & & & \\
\hline $\begin{array}{l}\text { Sávoly } \\
\text { Fekete-sziget }\end{array}$ & & & & & & & $x$ & & & \\
\hline $\begin{array}{l}\text { Sávoly } \\
\text { Nyírfás-sziget }\end{array}$ & & & & & $\mathrm{x}$ & & & $x$ & & \\
\hline $\begin{array}{l}\text { Sávoly } \\
\text { Sziget-dűlő }\end{array}$ & & & & & & & & & & $x$ \\
\hline $\begin{array}{l}\text { Szegerdő } \\
\text { Legelői-dúlő }\end{array}$ & & & & & $\mathrm{x}$ & & & & & \\
\hline $\begin{array}{l}\text { Vörs } \\
\text { Battyani-disznólegelő }\end{array}$ & & $x$ & & & $\mathrm{x}$ & $x$ & $x$ & $x$ & $x$ & $\mathrm{x}$ \\
\hline $\begin{array}{l}\text { Vörs } \\
\text { Kanászkert }\end{array}$ & & & $x$ & & & & & & & \\
\hline $\begin{array}{l}\text { Vörs } \\
\text { Kerekerdő }\end{array}$ & & $x$ & & & & $\mathrm{x}$ & $x$ & & $\mathrm{x}$ & $x$ \\
\hline $\begin{array}{l}\text { Vörs } \\
\text { Máriasszonysziget }\end{array}$ & $x$ & $\mathrm{x}$ & & & & $x$ & & & & \\
\hline $\begin{array}{l}\text { Vörs } \\
\text { Nyíres-sziget }\end{array}$ & & & $x$ & & $x$ & & $x$ & & & \\
\hline $\begin{array}{l}\text { Vörs } \\
\text { Papkert }\end{array}$ & & & $x$ & & & & & & & \\
\hline $\begin{array}{l}\text { Vörs } \\
\text { Papkert A }\end{array}$ & & & & & & & & $x$ & $x$ & \\
\hline $\begin{array}{l}\text { Vörs } \\
\text { Papkert B }\end{array}$ & & & & & & $\mathrm{x}$ & $\mathrm{x}$ & & $\mathrm{x}$ & \\
\hline
\end{tabular}

\section{Kis-Balaton medencéjének lelöhelyei}




\begin{tabular}{|c|c|c|c|c|c|c|c|c|c|c|}
\hline Lelöhely & $\begin{array}{l}\text { neolitikum } \\
\text { (Vonaldíszes } \\
\text { Kerámia k.) }\end{array}$ & $\begin{array}{l}\text { neolitikum- } \\
\text { kora rézkor } \\
\text { (Lengyeli k.) }\end{array}$ & $\begin{array}{c}\text { középső rézkor } \\
\text { (Balaton-Lasinja } \\
\text { k.) }\end{array}$ & $\begin{array}{l}\text { késő rézkor } \\
\text { (Badeni k.) }\end{array}$ & $\begin{array}{l}\text { kora bronzkor } \\
\text { (Somogyvár- } \\
\text { Vinkovci k.) }\end{array}$ & $\begin{array}{c}\text { kora bronzkor } \\
\text { (Kisapostagi k.) }\end{array}$ & $\begin{array}{c}\text { középső } \\
\text { bronzkor } \\
\text { (Mészbetétes } \\
\text { Kerámia k.) }\end{array}$ & $\begin{array}{l}\text { késő bronzkor } \\
\text { (Urnamezős k.) }\end{array}$ & $\begin{array}{l}\text { késő vaskor } \\
\text { (La Téne C-D) }\end{array}$ & kora császárkor \\
\hline $\begin{array}{l}\text { Vörs } \\
\text { Papkert C }\end{array}$ & & & & & & & & $\mathrm{x}$ & & \\
\hline $\begin{array}{l}\text { Vörs } \\
\text { Pogány-sziget }\end{array}$ & & & & & & & & & & $\mathrm{x}$ \\
\hline $\begin{array}{l}\text { Vörs } \\
\text { Tótok-dombja }\end{array}$ & $\mathrm{x}$ & & $\mathrm{x}$ & & & $\mathrm{x}$ & & & & \\
\hline $\begin{array}{l}\text { Zalavá } \\
\text { Berek }\end{array}$ & & & $\mathrm{x}$ & & & & & & & \\
\hline Zalavár & & $\mathrm{x}$ & & & & & & & & \\
\hline $\begin{array}{l}\text { Zalavár } \\
\text { Balatonhídvég }\end{array}$ & $\mathrm{x}$ & & $\mathrm{x}$ & & & & & & & \\
\hline $\begin{array}{l}\text { Zalavár } \\
\text { Belterület }\end{array}$ & $\mathrm{x}$ & & & & & & & & & \\
\hline $\begin{array}{l}\text { Zalavár } \\
\text { Hídvégi-kegelő }\end{array}$ & & & $\mathrm{x}$ & & & & & & & \\
\hline $\begin{array}{l}\text { Zalavár } \\
\text { Iskolaudvar }\end{array}$ & & & & $\mathrm{x}$ & & & & & & \\
\hline $\begin{array}{l}\text { Zalavár } \\
\text { Kövecses }\end{array}$ & & & $\mathrm{x}$ & & & & & & & \\
\hline $\begin{array}{l}\text { Zalavár } \\
\text { Lebujpuszta }\end{array}$ & & & $\mathrm{x}$ & & & & & & & \\
\hline $\begin{array}{l}\text { Zalavár } \\
\text { Mekenye }\end{array}$ & & $\mathrm{x}$ & $\mathrm{x}$ & & & & & & & \\
\hline $\begin{array}{l}\text { Zalavár } \\
\text { Nedám }\end{array}$ & & & & & & & & & & $\mathrm{x}$ \\
\hline $\begin{array}{l}\text { Zalavár } \\
\text { Ökörsziget }\end{array}$ & $\mathrm{x}$ & $\mathrm{x}$ & & & & $\mathrm{x}$ & & & & \\
\hline $\begin{array}{l}\text { Zalavár } \\
\text { Ürmös-puszta }\end{array}$ & & & & & & & $\mathrm{x}$ & $\mathrm{x}$ & & \\
\hline $\begin{array}{l}\text { Zalavár } \\
\text { Vársziget }\end{array}$ & & & & & & $\mathrm{x}$ & & & & \\
\hline
\end{tabular}

\section{Kis-Balaton medencéjének lelőhelyei}




\begin{tabular}{|c|c|c|c|c|c|c|c|c|c|c|}
\hline Lelöhely & $\begin{array}{c}\text { neolitikum } \\
\text { (Vonaldíszes } \\
\text { Kerámia k.) }\end{array}$ & $\begin{array}{l}\text { neolitikum- } \\
\text { kora rézkor } \\
\text { (Lengyeli k.) }\end{array}$ & \begin{tabular}{|c|}
$\begin{array}{c}\text { középsö rézkor } \\
\text { (Balaton-Lasinja } \\
\text { k.) }\end{array}$ \\
\end{tabular} & $\begin{array}{l}\text { késő rézkor } \\
\text { (Badeni k.) }\end{array}$ & $\begin{array}{l}\text { kora bronzkor } \\
\text { (Somogyvár- } \\
\text { Vinkovci k.) }\end{array}$ & $\begin{array}{l}\text { kora bronzkor } \\
\text { (Kisapostagi k.) }\end{array}$ & $\begin{array}{c}\text { középső bronzkor } \\
\text { (Mészbetétes } \\
\text { Kerámia k.) }\end{array}$ & $\begin{array}{l}\text { késő bronzkor } \\
\text { (Urnamezős k.) }\end{array}$ & $\begin{array}{l}\text { késő vaskor } \\
\text { (La Téne C-D) }\end{array}$ & kora császárkor \\
\hline $\begin{array}{l}\text { Balatonkeresztúr } \\
\text { Réti-dúlő }\end{array}$ & & & 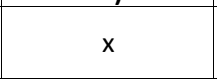 & $x$ & 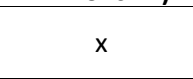 & $x$ & 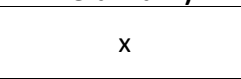 & & $x$ & \\
\hline \begin{tabular}{|l} 
Fonyód \\
Bézsenypuszta
\end{tabular} & & & & $x$ & & & & & $x$ & \\
\hline \begin{tabular}{|l|} 
Fonyód \\
Vasúti-dúlő
\end{tabular} & & & & $x$ & $x$ & & & & & \\
\hline \begin{tabular}{|l|} 
Sávoly \\
Bakos-domb
\end{tabular} & $x$ & $x$ & & $x$ & & & & & & \\
\hline $\begin{array}{l}\text { Szökedencs } \\
\text { Cölömpös-árok }\end{array}$ & $x$ & & & $x$ & $x$ & & & & $x$ & \\
\hline \begin{tabular}{|l|} 
Sávoly \\
Hupalagos
\end{tabular} & $x$ & & & & & & & & & \\
\hline $\begin{array}{l}\text { Szegerdő } \\
\text { Marótvölgyi-csatorna }\end{array}$ & & & & & & & & & $x$ & \\
\hline \begin{tabular}{|l|l|} 
Tikos \\
Bari-dúlő
\end{tabular} & & & & $x$ & & & & & $x$ & \\
\hline \begin{tabular}{|l|} 
Tikos \\
Homokgödrök
\end{tabular} & & & & $x$ & $x$ & $x$ & & $x$ & & \\
\hline \begin{tabular}{|l|} 
Tikos \\
Nyárfás-dúlő
\end{tabular} & & & & $x$ & & & & & $x$ & \\
\hline
\end{tabular}




\begin{tabular}{|c|c|c|c|c|c|c|c|c|c|c|}
\hline Lelőhely & $\begin{array}{l}\text { neolitikum } \\
\text { (Vonaldíszes } \\
\text { Kerámia k.) }\end{array}$ & $\begin{array}{c}\text { neolitikum-kora } \\
\text { rézkor } \\
\text { (Lengyeli k.) }\end{array}$ & $\begin{array}{l}\text { középső rézkor } \\
\text { (Balaton-Lasinja k.) }\end{array}$ & $\begin{array}{l}\text { késő rézkor } \\
\text { (Badeni k.) }\end{array}$ & $\begin{array}{l}\text { kora bronzkor } \\
\text { (Somogyvár- } \\
\text { Vinkovci k.) }\end{array}$ & $\begin{array}{l}\text { kora bronzkor } \\
\text { (Kisapostagi k.) }\end{array}$ & $\begin{array}{c}\text { középső bronzkor } \\
\text { (Mészbetétes Kerámia } \\
\text { k.) }\end{array}$ & $\begin{array}{l}\text { késő bronzkor } \\
\text { (Urnamezős k.) }\end{array}$ & $\begin{array}{l}\text { késő vaskor } \\
\text { (La Téne C-D) }\end{array}$ & kora császárkor \\
\hline $\begin{array}{l}\text { Balatonkeresztúr } \\
\text { Réti-dúlő }\end{array}$ & & & $x$ & $x$ & $x$ & $x$ & 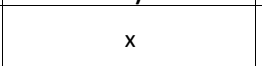 & & $x$ & \\
\hline $\begin{array}{l}\text { Balatonmagyaród } \\
\text { Hídvégpuszta }\end{array}$ & $x$ & $x$ & $x$ & $x$ & $x$ & $x$ & & $x$ & & $x$ \\
\hline $\begin{array}{l}\text { Balatonmagyaród } \\
\text { Kányavári-sziget }\end{array}$ & $x$ & & & $x$ & & & & $x$ & $x$ & \\
\hline \begin{tabular}{|l|} 
Balatonmagyaród \\
Kiskányavár
\end{tabular} & & $x$ & $x$ & $x$ & & & & & $x$ & \\
\hline \begin{tabular}{|l} 
Balatonmagyaród \\
Szarkavári-sziget
\end{tabular} & & $x$ & $\mathrm{x}$ & & $x$ & & & & $x$ & $x$ \\
\hline \begin{tabular}{|l|} 
Keszthely \\
Fenékpuszta
\end{tabular} & $x$ & & & $x$ & & $x$ & $x$ & & $x$ & \\
\hline $\begin{array}{l}\text { Keszthely } \\
\text { Gáti-domb }\end{array}$ & & & $x$ & $x$ & & & & $x$ & $x$ & \\
\hline $\begin{array}{l}\text { Szökedencs } \\
\text { Cölömpös-árok }\end{array}$ & $x$ & & & $x$ & $x$ & & & & $x$ & \\
\hline \begin{tabular}{|l} 
Tikos \\
Homokgödrök
\end{tabular} & & & & $x$ & $x$ & $x$ & & $x$ & & \\
\hline \begin{tabular}{|l} 
Vörs \\
Battyáni-disznólegelő
\end{tabular} & & $x$ & & & $x$ & $x$ & $x$ & $x$ & $x$ & $x$ \\
\hline \begin{tabular}{|l|} 
Vörs \\
Kerékerdő \\
\end{tabular} & & & & & & $x$ & $x$ & & $x$ & $x$ \\
\hline
\end{tabular}

